Historic, archived document

Do not assume content reflects current scientific knowledge, policies, or practices. 

62.73

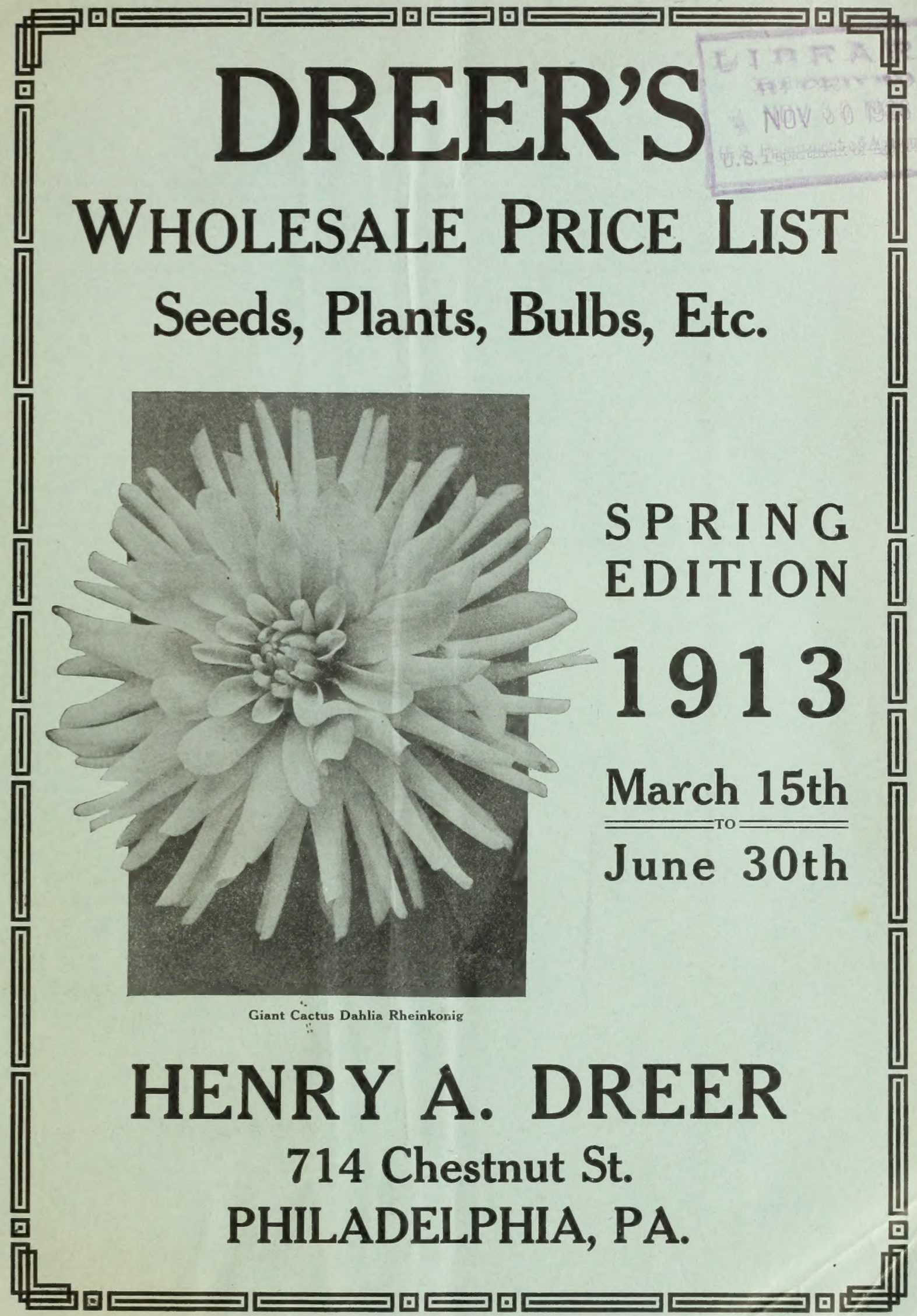




\section{Dreer’s Quarterly Wholesale Price List}

\section{MARCH 15th-JUNE 30th, 1913}

We take pleasure in presenting to the Trade this, the second issue of our Wholesale Price List for 1913. New Crop Seeds are now in stock and ready for distribution, and we are confident, notwithstanding many short crops that we can serve you as well as ever. In the Plant Department our stocks of decorative, hardy and other plants are very extensive and in splendid condition, comparing favorably to stock distributed by us in the past. We trust you will favor us with a share of your patronage which we promise will be given the most careful attention.

\section{ORDER EARLY OR}

WE respectfully request that our wholesale customers send in their orders as early as possible. While we aim to give every order proper attention at all seasons of the year, yet during the spring rush there is liable to be delays, hence the advisability of anticipating your wants and ordering early.

SHIPPING.-By our careful and thorough system of packing, we Guarantee Safe Delivery of plants and perishable goods, when ordered to be sent by Express, and we always ship this way unless we have positive instructions to the contrary, and when sent in any other way, are solely at purchaser's risk.

PRICES. - This list cancels all previous offers. The prices quoted in this list are net, and subject to no discounts. Articles offered in our Retail Catalogue or Garden Book and not offered in this list will be supplied at retail prices less the following discounts, viz.: Vegetable and Flower Seeds in packets, Bulbs and Plants, 331/3\% ; Small Tools and Insecticides, $10 \%$.

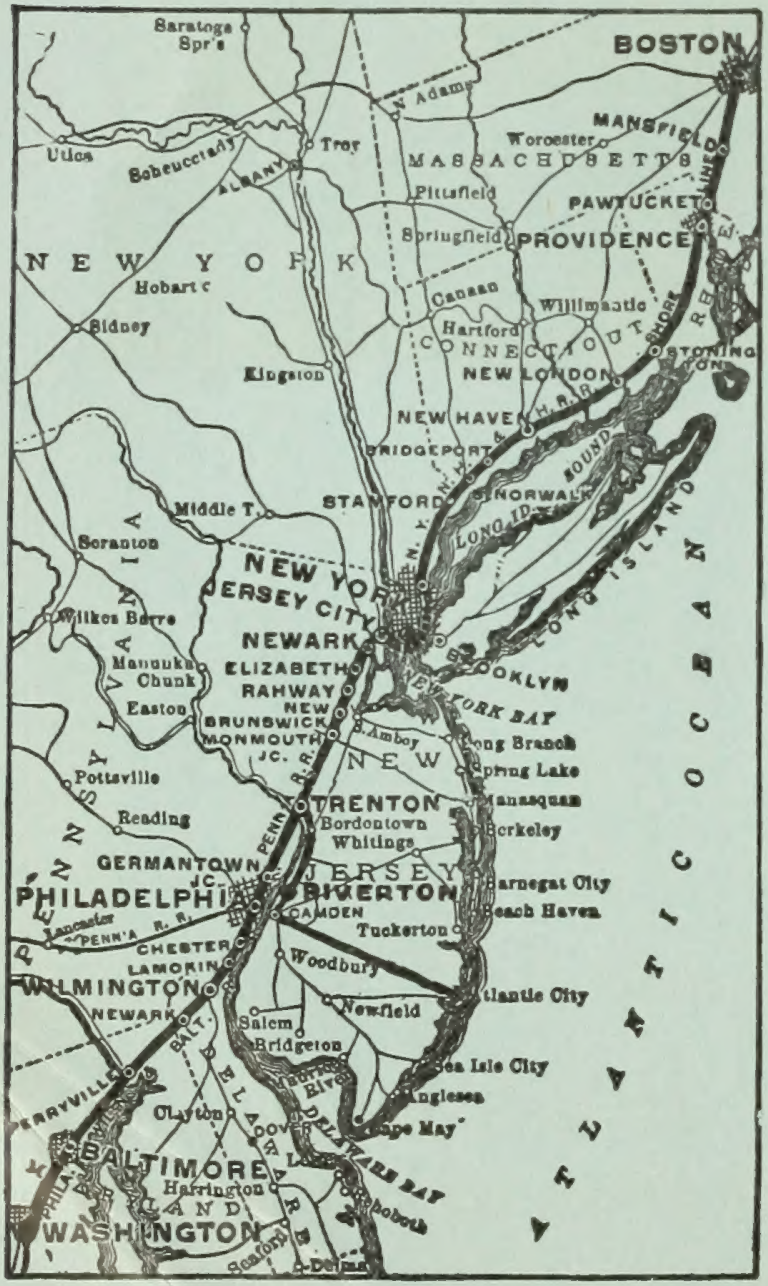

No order for PLANTS or BULBS amounting to less than $\$ 1.00$ will be filled and packed at wholesale prices. Orders received from the trade for Plants or Bulbs amounting to less than $\$ 1.00$ will be charged for at retail prices, less 10 per cent.

TERMS OF BUSINESS.-Unknown correspondents desiring to open an account will please furnish three references to parties in the trade with whom they have had credit relations, otherwise cash must accompany order.

Remittances should be made by Post-Office Money Orders, Drafts on New York or Philadelphia banks, or Express Money Orders. Where it is not possible to obtain these, the letter should be registered. We cannot guarantee receipt of money sent in any other way.

50 Goods desired C. O. D. must be accompanied by a partial remittance to guarantee acceptance.

All goods are oifered subject to being unsold on receipt of order, and we reserve the right to advance prices without notice.

no No charge is made for boxes or packing, nor for delivery to Freight Depots or Express Offices in Philadelphia.

neg-In filling unt your order always give Shipping Directions, and write Name and Addresg Distinctly on each and every order.

NON-WARRA NTY. - We wish it to be distinctly understood that although we continue to take all possible pains to supply only New, Genuine and Unadulterated Seeds, Plants and Bulbs, we still give no warranty, express or implied, as to description, quality, productiveness, or any other matter of any of the Seeds, Plants or Bulbs we send out, and will not be in any way responsible for the crop. Every order received for articles named in this Catalogue will be executed on these conditions only. 


\section{FLORISTS' ORDER SHEET}

\section{HENRY A. DREER, \\ 714 CHESTNUT STREET \\ Philadelphia, Pa.}

Date,

Forward by (State whether wanted by $)$

PLEASE DO NOT WRITE HERE

Name, ( $\begin{gathered}\text { Please Prefix } \\ \text { Mr., Mrs. or Miss })\end{gathered}$

Street, P. O. Box or

Rural Dellvery

Post Office,

Express Office, ( $\left.\begin{array}{c}\text { If different } \\ \text { from P. } 0 .\end{array}\right)$

County,

State,

Amount Enclosed, Express Money Order. Draft, $\$$

Postage Sta

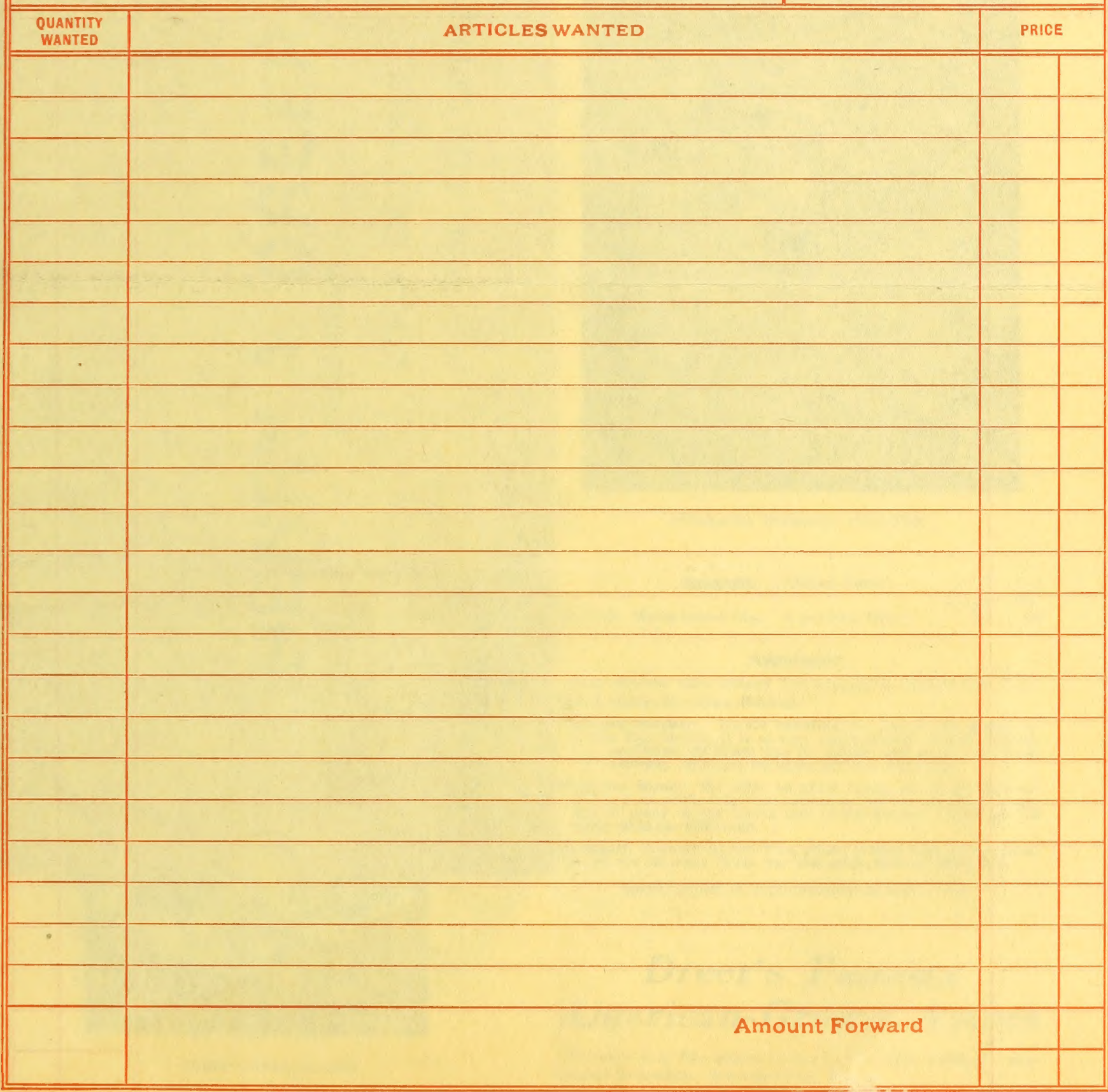


From

SEED WAREHOUSE, 714 CHESTNUT ST.
PUT STAMP HERE

\section{HENRY A. DREER,}

LOCK BOX 1618, PHILADELPHIA, 


\section{WHOLESALE PRICE LIST OF}

\section{Dreer's Reliable Flower Seeds}

We give close attention to the Flower Seed Department, our constant aim is to procure the very best strains obtain able, both of home and foreign growth, and no pains or expense are spared with this object in view. We call special attention to our particularly fine strains of Asters, Cinerarias, Cyclamens, Mignonettes, Pansies, Petunias, Primulas, Stocks, Verbenas, etc., etc. They are now grown by the most critical florists in the country and are acknowledged to be superior in all respects.

NOTE.-We do not furnish less than Trade Packets. Fractions of ounces are supplied at a slight advance over the ounce price. Where smaller quantities than trade packets are wanted retail packets can be supplied at a discount of one=third from retail catalogue prices. Prices in this list are net.

Ageratum (Floss Flower).

Splendid bedding plants, snould be sown early to get good size plants for spring sales.

Blue Perfection. Best dark blue bedder Cope's Pet. Fine light blue bedder

Imperial Dwarf Blue. Fine compact sort

White.

Little Blue Star. Very dwarf

Princess Pauline. Sky blue, white centre

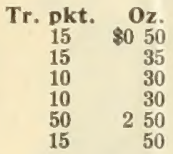

Alyssum (Sweet Alyssum). Tr. pkt. Oz. 1/4-Lb. Little Gem (Carpet of Snow). Very dwarf, the

best for pots. Extra select stock

Tom Thumb. Dwarf ereet growth

Maritimum (Sweet Alyssum). White, trailing

$\begin{array}{llll}15 & 40 & \$ 1 & 50\end{array}$

Antirrhinum (Snapdragon).

Largely used for cutting, both summer and winter. Tr. pkt. Oz. Majus Mixed. A fine strain of the tall variety Giant Snapdragons. A tall-growing strain with long spikes of very large individual flowers. Splendid for cutting.

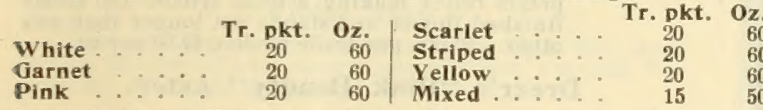

Large=flowering Half=dwarf Sorts. Of compact bushy habit, grow ing about 18 inches high and producing freely good spikes of large flowers. The best type for bedding, and useful for cutting.

Daohne. Soft rose-pink

Deflance. Fiery scarlet

Golden Queen. Rich yellow

Firebrand. Rich deep red

Rose Queen. Rich rose

Mont Blanc. Pure white

Finest Mixed. All color

Tr. pkt. Oz.

$\begin{array}{lr}\text { pkt. } & \text { Oz. } \\ 20 & 60 \\ 20 & 60 \\ 20 & 60 \\ 20 & 60 \\ 20 & 60 \\ 20 & 60 \\ 15 & 50\end{array}$

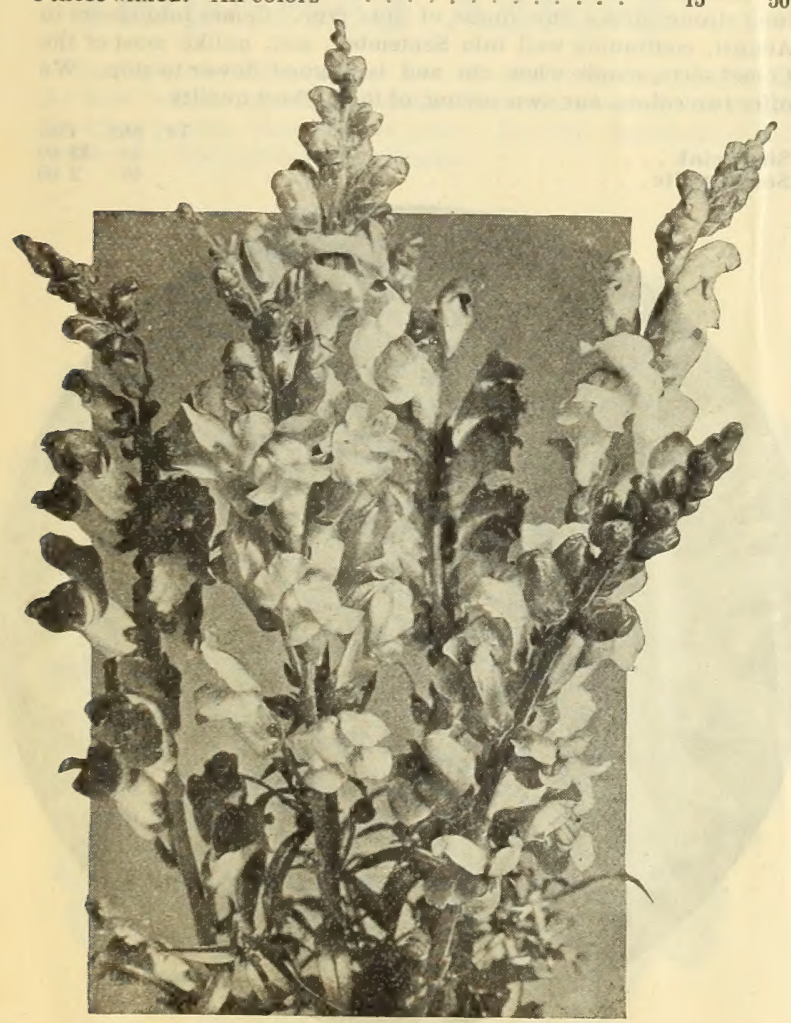

DREER'S SNAPDRAGONS

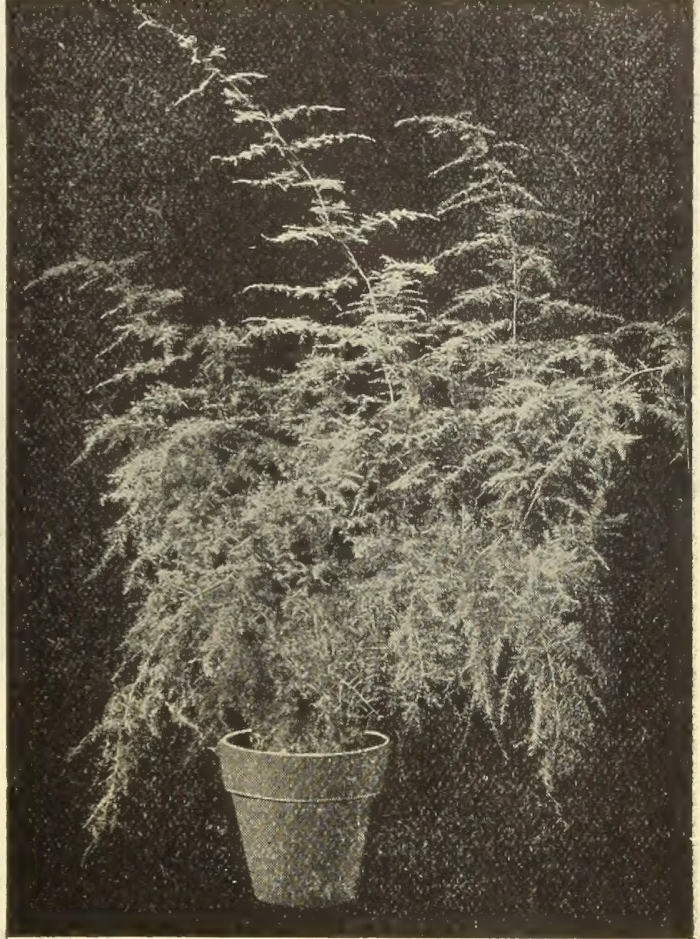

ASPARAGUS PLUMOSUS HATCHERI

Arctotis (African Daisy).

Grandis. White tinged lilac. A good cut flower, 15

\section{Asparagus.}

The varieties here offered are wanted in quantity by every florist, always in strong demand.

Plumosus Hatcheri. We are handling the crop of the originator of this fine variety; it is of very rapid growth, closely jointed, and considered the finest type for strings and equally valuable for bunching. $\$ 1.00$ per 100 seeds; $\$ 7.50$ per 1000 seeds.

Plumosus nanus. We offer an extra choice lot of greenhousegrown seed, of the true type wanted by florists and much superior to many of the stocks now on the market. 50 cts. per 100 seeds; $\$ 4.00$ per 1000 seeds.

Sprengeri. Open-air-grown, fine, plump seed of high germination. 25 cts. per 250 seeds; 75 cts. per 1000 seeds; $\$ 3.00$ per 5000 seeds.

Special prices on large quantities on application.

\section{Dreer's Famous American-Grown Asters}

We have very fine strains of the leading sorts, which are unequalled for quality. See pages 2 and 3. 


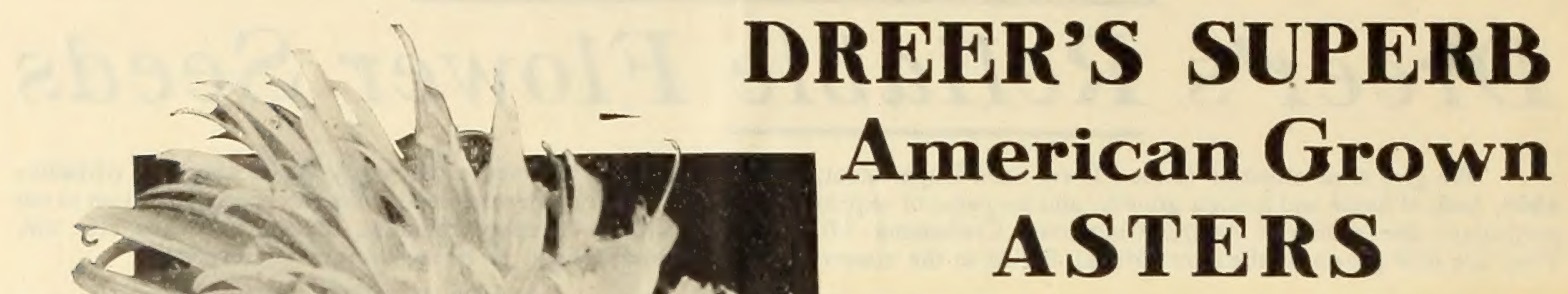

The varieties offered on this and the head of next page are all American grown and stand at the head of Asters for the American climate.

The stocks have all been grown under our own supervision, and we know that the quality in every case is as fine as can be had at any price and much superior to what can be procured from most sources.

Dreer's "Peerless Pink" Aster.

This grand Aster may briefly be described as a glorified late branching shell-pink or Mary Semple. It has the same strong, sturdy habit of growth; comes into bloom a little earlier, bears freely almost globular flowers rarely under 4 inches across and frequently over 5 inches. The color is rich shell-pink, similar in shade but more decided than the late branching. The centre petals are prettily incurved while the wide outer petals reflex making a most artistic and finely finished flower and stands cut longer than any other. $50 \mathrm{cts}$. per trade packet; $\$ 2.50$ per $0 \mathrm{z}$.

Dreer's “Pink Beauty" Aster.

A magnificent cut-flower variety, in bloom from early August until well on in September; 24 to 30 inches high; flowers average 4 inches across, on long, strong stems. Color a delicate blush pink, and pronounced by experts to be the finest pink midseason sort yet introduced. 50 cts. per trade pkt; $\$ 4.00$ per oz.

MIKADO ASTER

\section{Crego's Giant Comet Asters.}

\section{Mikado Asters.}

Very similar to Crego's Giant but dwarfer and earlier. Flowers of largest size rarely under 5 inches across, borne on good long stems, we offer two colors.

Mikado Pink or Rochester Mikado White

Tr. pkt. Ox. $40 \$ 200$

\section{Giant Comet Asters.}

Giant Branching. Finest mixed, long stems and fine for cutting

\section{Dreer's "Crimson King" Aster.}

A superb new late-branching variety, with perfect double flowers of rich, rosy crimson, full of fire. Fine for cutting, showing up well under artificial light. $40 \mathrm{cts}$. per trade pkt; $\$ 2.00$ per oz.

\section{Dreer's Superb Late Branching Asters.}

The finest Asters for late August and September blooming. The plants form strong, branching bushes, 2 to $2 \frac{1}{2}$ feet high, bearing on long, strong stems their handsome Chrysanthemumlike flowers, which, under ordinary cultivation average 5 inches across. The form of the flowers, together with the length of the stems, places them at the head of Asters for cutting. They come into bloom from two to three weeks after the average type, usually being at their best during September, and filling in the gap between the general run of Asters and Chrysanthemums. We offer eight beautiful and distinct colors, viz:

Azure Blue, A rich deep lavender Pure White. Extra fine stock Shell Pink. An exquisite shade Rose Pink. A very desirable color Deep Rose. Rich and brilliant. Deep Purple. Royal deep blue.

Deep Purple. Royal deep blue... Lavender. A pale gre

Crimson. Very rich
Finest Mixed. All the colors.
Tr. pkt. Oz. $25 \quad \$ 100$ $25 \quad 100$ $25 \quad 100$ $25 \quad 100$ 25100 25100 $25 \quad 100$ 25100
Magnificent fluffy flowers, averaging over 5 inches across, with long strong stems; the finest of this type. Comes into bloom in August, continuing well into September, and, unlike most of the Comet sorts, stands when cut and is a good flower to ship. We offer two colors, our own saving, of the highest quality.

Shell-pink.
Snow - white.

Tr. pkt. Ox. $\begin{array}{rrr}40 & \$ 2 & 00 \\ 40 & 2 & 00\end{array}$

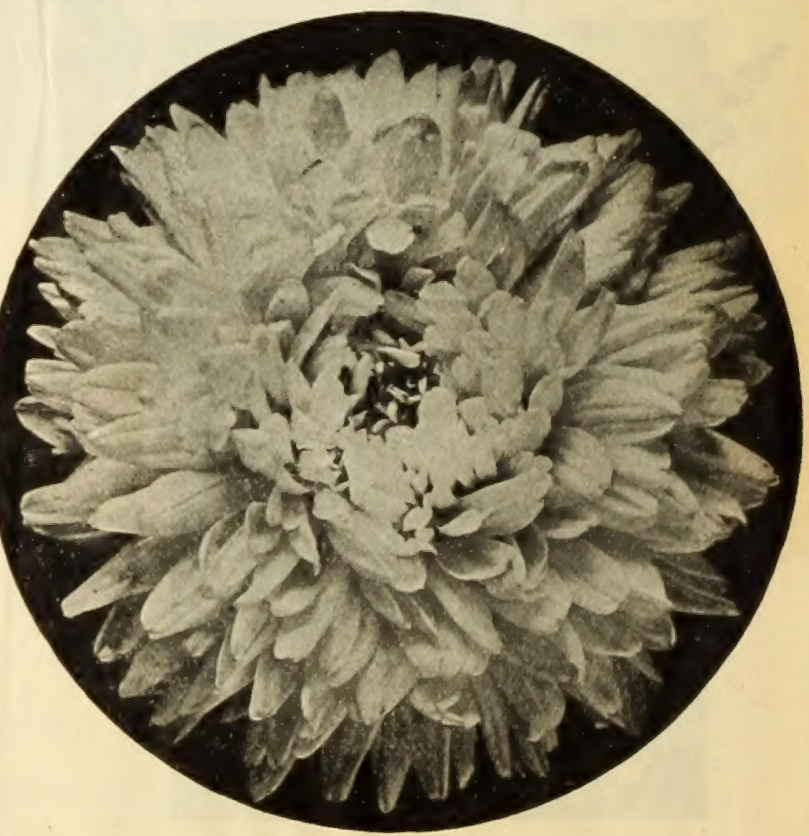

DREER'S SUPERB LATE BRANCHING ASTER 


\section{Dreer's Superb American Grown Asters}

\section{Electric White.}

A most distinct and distinguished looking flower. being made up of snowy whiteness, borne on long, strong wiry stems, and rarely under 5 inches across. 40 ets. per trade pkt. $\$ 2.00$ per 02 .

\section{Daybreak.}

Of symmetrical growth: attains a height of 18 inches and produces during August perfect globeshaped flowers, of a delicate pink tint. $40 \mathrm{cts}$. iper trade pkt.; 82.00 per oz.

\section{Purity.}

Identical in every way to Daybreak, but of pure glistening white. $50 \mathrm{cts}$. per trade pkt.; $\$ 2.50$ per oz.

\section{Lavender Gem.}

One of the most beautiful Asters. Of Comet type, with large, artistic, loosely-arranged flowers of the most charming shade of lavender imaginable. 50 cts. per trade pkt.; $\$ 3.00$ per oz.

\section{Violet King.}

A distinct color in the Late Branching class, fine large double flowers of a pleasing shade of violet, a strong, free grower. 25 cts. per trade pkt.; $\$ 1.00$ per oz.

\section{White Fleece.}

Large and most perfect flowers, 5 inches and over across, formed into a plumy globe of glistening white. $₹$ Blooms in August. 50 cts. per trade pkt.; $\$ 3.00$ per $0 z$

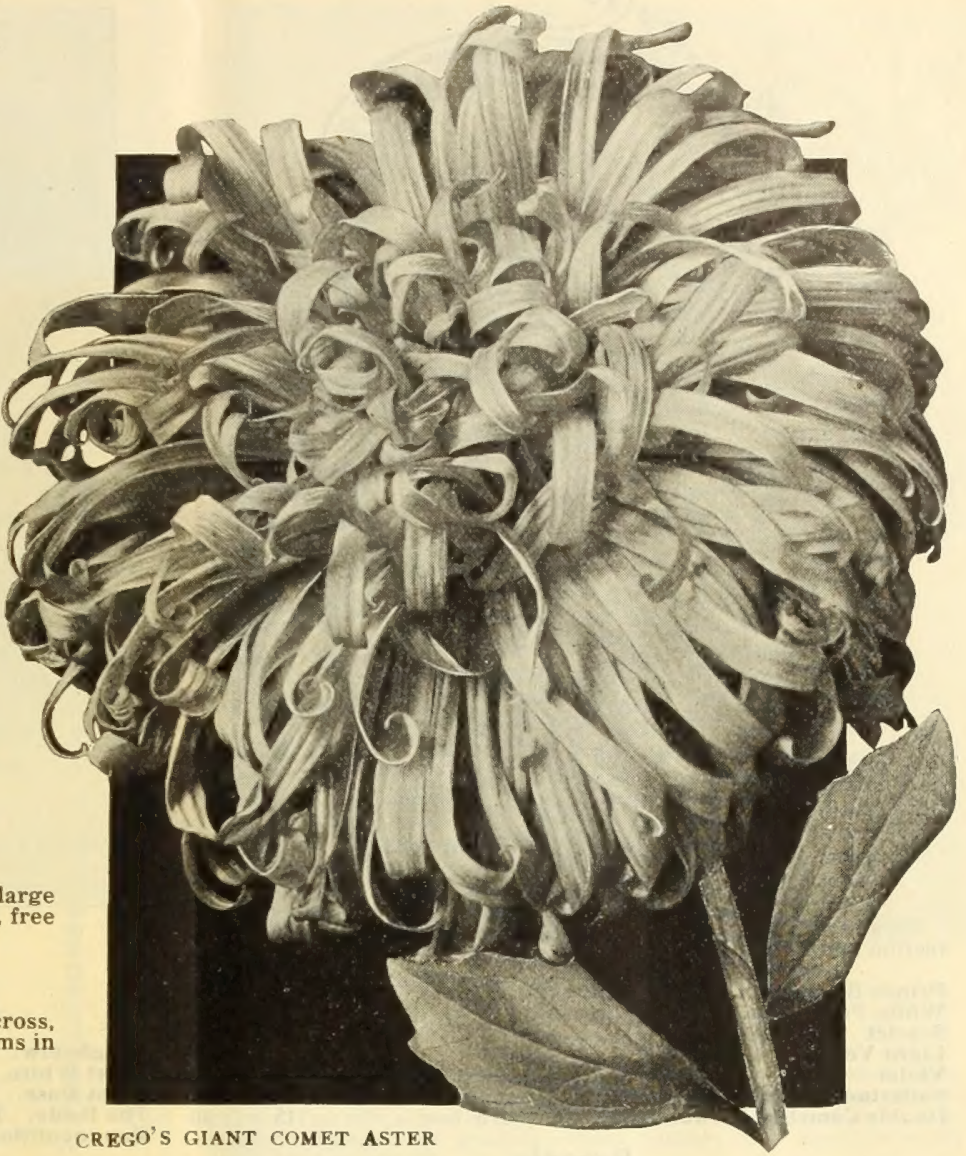

\section{Imported Asters}

The varieties offered below are all imported, procured from the most reliable specialists, our aim in every instance being to get the finest quality, regardless of price. For full descriptions see our Garden Book or Retail Catalogue.

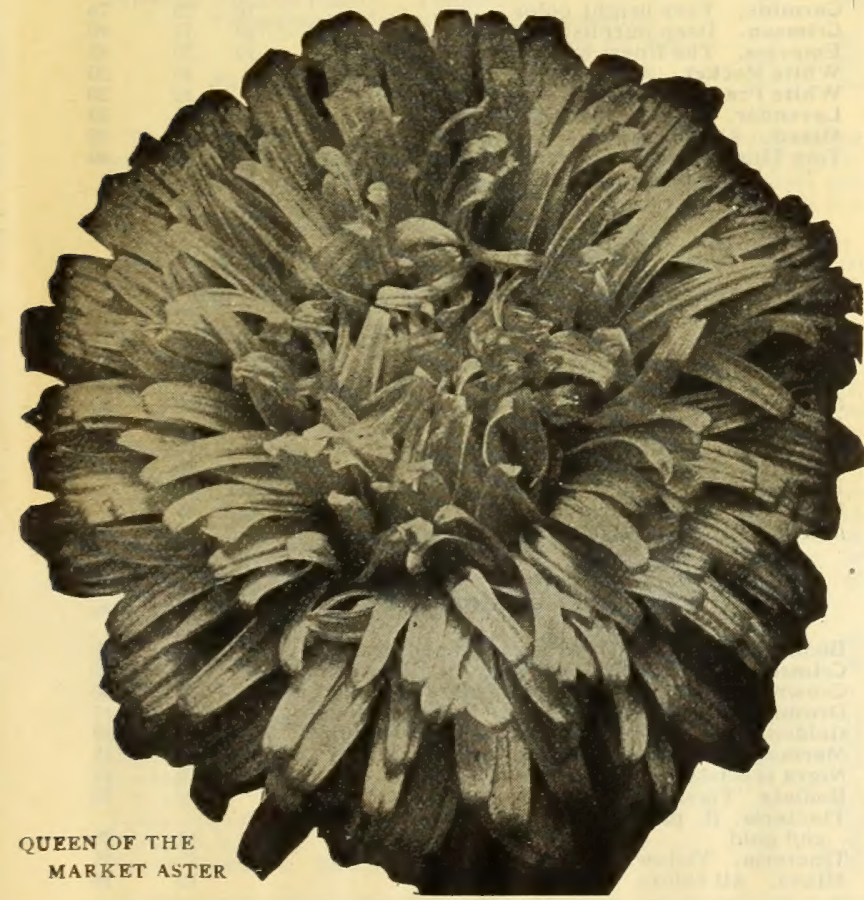

Early Wonder Asters.

This is the earliest Aster in cultivation, being in full bloom when Queen of the Market is only in bud, frequently coming into bloom in late June. Flowers larger than Queen of the Market, borne on long, strong stems. Very valuable for cutting.

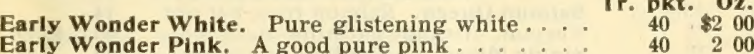

Ostrich Feather Asters.

White

Lavender

Bright rose

Salmon pink, extra fine.

Violet blue

Vivid crimson.

Mixed .

Pæony Perfection Asters.

Crimson.

Light blue

Brilliant rose

Purple.

Bright pink

Pure white

Finest mixed

Queen of the Market Asters.

White.

Lavender

Pink

Bright rose

Purple

Mixed..

Very early
flowering
extra choice
stock

Improved Victoria Asters.

Peach-blossom pink

Dark scarlet.

Light blue

Purple.

Pure white

Rose, tinted white

Finest mixed

$\begin{array}{llll}30 & & 1 & 50 \\ 30 & & 1 & 50 \\ 30 & & 1 & 50 \\ 30 & & 1 & 50 \\ 30 & & 1 & 50 \\ 30 & & 1 & 50 \\ 30 & & 1 & 25\end{array}$

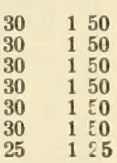

For condensed list and Hardy Perennial Seeds see pages 13 to 15. 


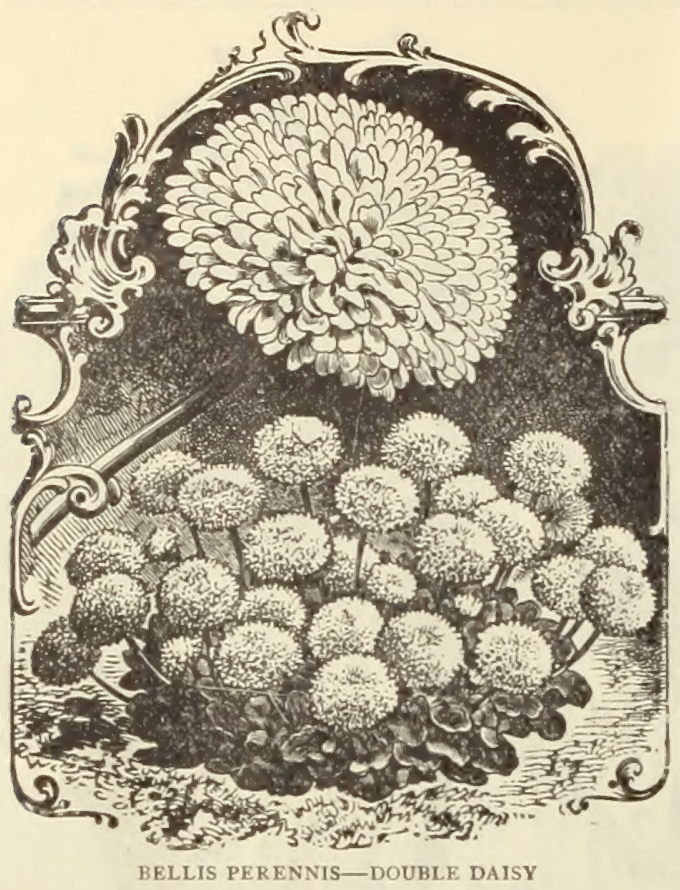

Balsam.

These are highly useful, the stemmed flowers of the White Perfection and Prince Bismarck being excellent for making up.

Prince Bismarck. Very double, salmon pink White Perfection. Best double white

Scarlet

Light Yellow

Violet

all very double

Solferino, spotted

Double Camellia-Flowered Mixed. Extra fine

$\begin{array}{cr}\text { Tr. pkt. } & \text { Oz. } \\ 25 & \$ 100 \\ 25 & 100 \\ 15 & 60 \\ 15 & 60 \\ 15 & 60 \\ 15 & 60 \\ 15 & 40\end{array}$

\section{Begonia.}

The varieties of Semperflorens are probably the best bedding plants in existence for semi-shady positions. seed.

Semperflorens, Erfordia. Rosy carmine.

Gracllis rosea. Rose
Luminosa. Fiery red.
Prima Donna. Rose, per pkt.
Salmon Queen. Salmon rose, per pkt.
Vernon. Orange carmine .
Single Mixed. All colors. . . .
d. Single mixed.
Double.

Tr. pkt. Oz. 80
30

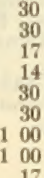

Frilled. Per pkt.

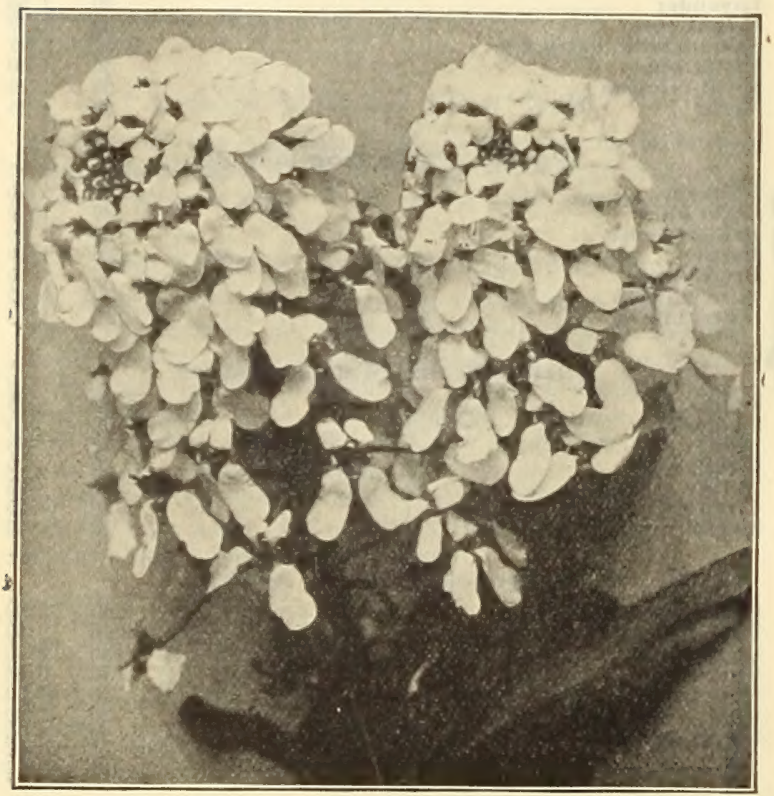

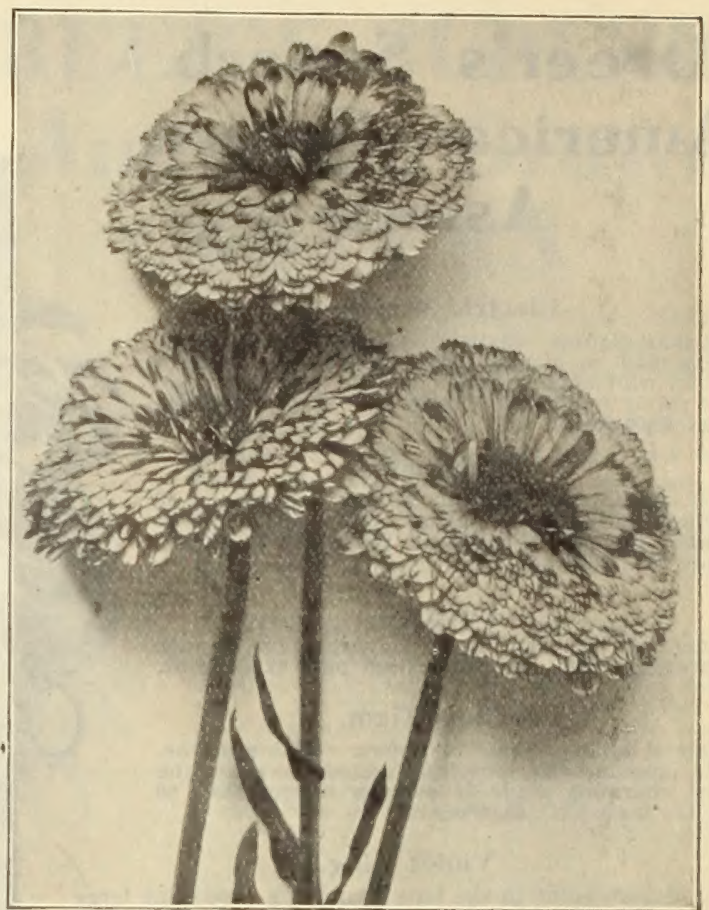

DOUBLE CALENDULA (Pot Mangold)

Bellis perennis (Double Daisy). Trokt. Oz.

Longfellow. Double pink Daisy , . . $40 \$ 200$ Giant White. Enormous flowers......... $50 \quad 250$ Giant Rose. Mammoth flowers $\quad 50 \quad 250$

The Bride. The finest double white, . . . . . $50 \quad 200$

Ranunculiflora Alba. Very double white . . $\quad \begin{aligned} & 50 \\ & 250\end{aligned}$

Snowball. Fine double white $\quad 30 \quad 150$

Double Quilled. A fine type, 14 cts, per pkt.

Finest Double Mixed. Best quality obtainable $\quad 30 \quad 150$

\section{Candytuft.}

Valuable for cutting, especially during the spring months.

Carmine. Very bright color ...

Crimson. Deep purplish crimson.

Empress. The finest white, a select stock

Tr. pkt. Oz. $1 / 1 \mathrm{Ib}$.

$\begin{array}{rrr}10 & 25 & 75 \\ 15 & 40\end{array}$

White Rocket. A good white . . . . . . $10 \quad 20$

White Fragrant. Small, sweet scented . . . . . 1020

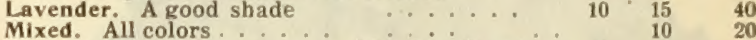

Tom Thumb, white. "A pure white dwarf sort : $10 \quad \begin{array}{lll}10 & 20 \\ 40\end{array}$

$\begin{array}{rrrr}\text { Tom Thumb, white. A pure white dwarf sort. . } & 10 & 15 \\ \text { mixed. Very dwarf, all colors . . } & 15 & 40\end{array}$

\section{Calendula (Pot Marigold).}

All of these are fine for cutting or for selling as pot plants.

Tr. pkt. Oz. $1 / 4-1 b$.

Meteor. Yellow striped orange

Prince of Orange. Somewhat darker than above

Orange King. Dark orange

Pure Gold. Fine golden yellow

Sulphurea. Double sulphur yellow.

Favorite. Light yellow, striped white

Favorite, Light yellow, striped white . . *
Pongell, fl. pl. Double white

$\begin{array}{llll}\text { Pluvialis. (Cape Marigold). Single white. . . . } & 10 & 15 \\ \text { Mixed. All the double sorts. } & & 10\end{array}$

\section{Calliopsis.}

Tr. pkt. Oz.

Bicolor Nana. Yellow with garnet eye; dwarf...

Crimson King. Rich dark crimson. Very compact.

Crown of Gold. Large golden yellow; fine for cutting

Drummond. Golden Wave. Golden yellow

Golden Ray. Yellow and brown, narrow petals ...

Marmorata. Yellow marbled, wallflower red

Nigra speciosa. Deep crimson

Radiata "Tiger Star." Brown spotted yellow : :

Tinctoria, fi. DI. Double and semi-double, maroon

and gold

Tinctoria, Yellow, maroon centre .........

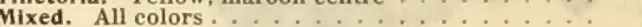




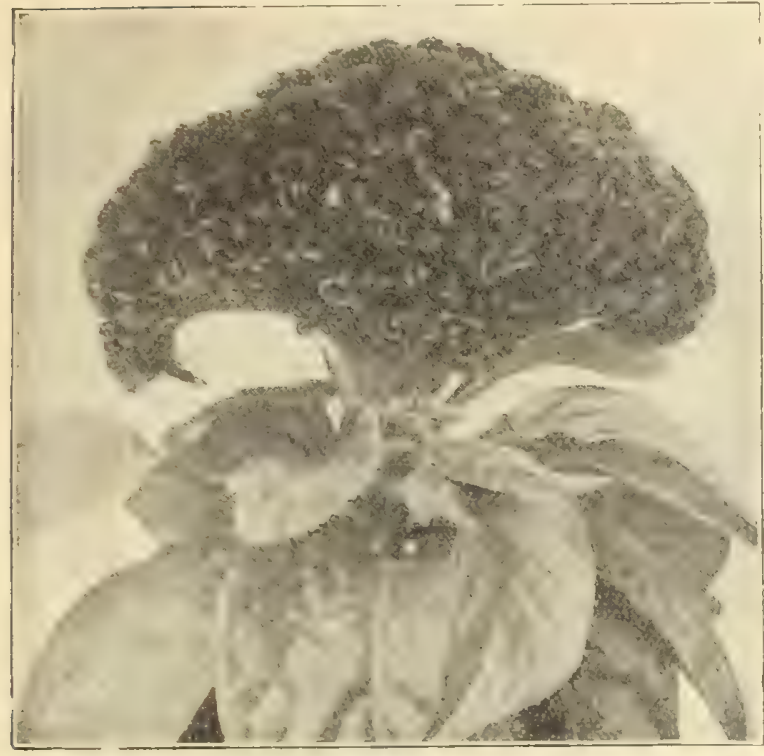

CELOSIA CRISTATA (COCKSCOMB)

\section{Carnation.}

The Chabaud and Marguerite come into flower early in summer. supplying a good crop of flowers for cutting up to frost.

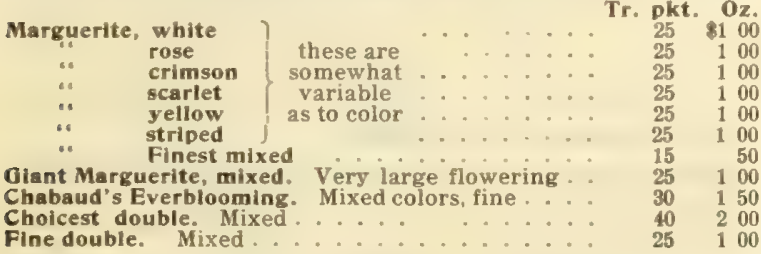

\section{Celosia.}

The Cristata or "Cockscomb" varieties are in good demand for beds, borders and pots. The Plumosa or "Feathered" sorts are magnificent bedding plants, and are becoming more popular each season.

\section{Cristata, Glasgow Prize. Dark erimson}

“. Empress. Dark purplish crimson

". Queen of Dwaris, Dark crimson rose

". Veriegata. Curiously variegated, tall Mixed. Dwarf sorts

Plumosa, Golden Plume. Yellow.

Thompsonii (Triomphe de l'Exposition)

$$
\text { ¿ } \quad \text { Magnifica. Various colors... }
$$
Mixed. All colors

\section{Centaurea.}

Tr. pkt. Oz.

$\begin{array}{rr}25 & \$ 100 \\ -25 & 100\end{array}$

$\begin{array}{rrr}-25 & 1 & 00 \\ 25 & 1 & 00 \\ 15 & & 0\end{array}$

$15 \quad 50$

$15 \quad 50$

$15 \quad 50$

20
10

The varieties Candidissima and Gymnocarpa are the white-leaved sorts so much in use for borders, vases, baskets, etc. To get plants in time the seeds should be sown early. The flowering kinds are now very popular especially the Double Blue Cornflower and the Imperialis (Royal Sweet Sultans). Candidissima. White leaved . . 1000 seeds 25 cts Gymnocarpa.

Imperialis, pure white.

$$
\because \quad \begin{aligned}
& \text { brilliant rose } \\
& \text { deep lavender } \\
& \because \quad \\
& \text { deep rose } \\
& \text { delicate lilac }
\end{aligned}
$$

Suaveolens, (Yellow Sweet Sultan or Grecian Corn Flower)

Americana. Reddish lavender

Cyanus, blue, (Corn Flower) . 40 cts. per $1 / 4-1 \mathrm{~b}$.

“ rose. Soft, rosy pink

" mixed. Various colors " 40 cts per $1 / 4-1 \mathrm{~b}$ "

16 double blue. We are glad to be able to offer this fine cut flower variety in quantity this

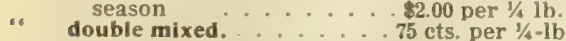

\section{Chrysanthemum.}

Coronarium Double Annual, Mixed.

Single Annual. Mixed colors

Segetum, Evening Star or Helios, Golden yellow

Inodorum plenissimum. Double white, good cut flower.

Frutescens Grandiflorum (White Paris Daisy)

Japanese hybrid. Large flowering mixed .

Hardy Pompon. Doubled mixed
Tr. pkt. Ox

\begin{tabular}{ll}
15 & 35 \\
15 & 60 \\
15 & 60 \\
15 & 60 \\
15 & 60 \\
15 & 60 \\
10 & 40 \\
10 & 25 \\
15 & 40 \\
10 & 15 \\
10 & 20 \\
10 & 20 \\
10 & 15 \\
& \\
15 & 60 \\
10 & 30 \\
& \\
10 & 15 \\
10 & 15 \\
10 & 25 \\
15 & 50 \\
15 & 50 \\
50 & 400 \\
50 & 300 \\
& \\
\hline
\end{tabular}

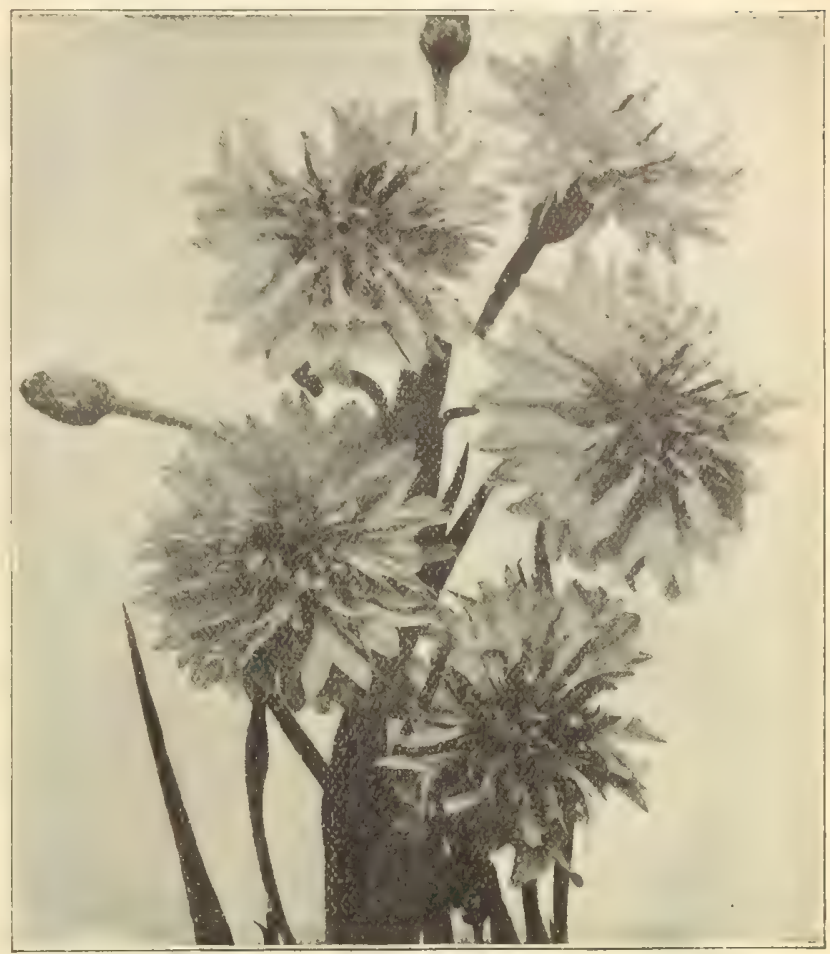

DREER'S DOUBLE BLUE CORNFLOWER

\section{Cineraria.}

Our Prize Strain of Hybrid Cineraria is the finest procurable. Stellata makes a handsome plant for Easter decorations; easy to grow. The white-leaved Maritima sorts or "Dusty Millers" are much in demand for bedding, vases, baskets, etc. Sow the seeds early for best results.

Tr. okt.

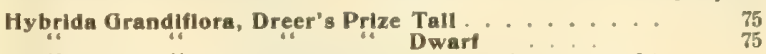

Stellata (Star Cineraria). Mixed. .

Cineraria (White-leaved sorts).
Maritima, candidissima. White-leaved
Tr. pkt. $\quad$ Oz. $_{20}$ 


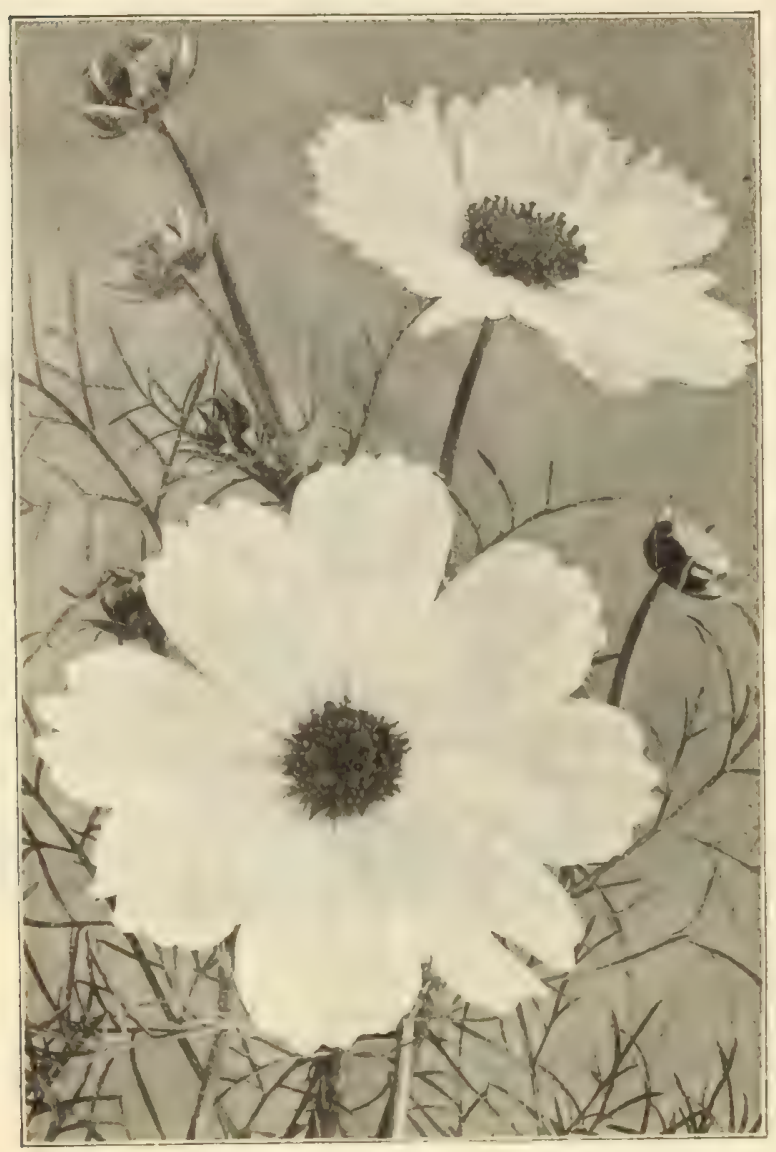

MAMMOTH PERFECTION COSMOS

\section{Cobrea (Cups and Saucers Vine).}

One of the best climbers, will cling to any rough surface. Always a good sale for plants of this. Seed should be sown early and placed a good sale for plants

Scandens. Purple white
Alba. Wha

$\begin{array}{cr}\text { Tr. pkt. } & \text { Oz. } \\ & 40\end{array}$

\section{Cosmos.}

Our Mammoth Perfection strain is unequaled for size and other good qualities. For Doints north of New York we recommend the Extra early flowering ty pes.

Mammoth Perfection, crimson

$$
\begin{aligned}
& \text { White } \\
& \text { Ainest mixed }
\end{aligned}
$$

Tr. pkt. Oz.

Gigantic flowering. "Lady Lenox." immense flowers 6 to 7 inches across, color a clear pink

Extra Eariy-flowering crimson.

". Wawn. White, tinged pink

is $\quad$ is Dink.

mixed

\section{Dianthus (Pinks).}

Double Flowering Sorts.

Tr. okt. Oz.

Chinensis (China Pinks). Mixed ........ 108020

Diadematus (Diadem Pinks), Mixed extra fine... 15

Heddewigil (Double Japan Pinks). Mixed, extra fine 15

Imperlalis (Imperial Pinks) Mixed . M *.... $15 \quad 40$

Laciniatus (Double Fringed Pinks). Mixed . . . . 15,50

Lucifer. Double, rich, geranium-red . Mixed colors $\quad 30 \quad 150$

Mourning Cloak. Maroon, edged white

Nobills (Double Royal Pinks). Mixed colors . . . $25-100$

Snowball. A beautiful double white....... 20

Striped Beauty. Very gay, Many colors. . t . 20

Violet Queen. Rich violet.

\section{Single Flowering Sorts.}

Crimson Belle. Rich velvety crimson ........ 15

Heddewill A beau-

tiful single strain

Laciniatus (Single Fringed Pinks)" Mixed

Mirabilis (Single Marvelous Pinks). Mixed .

Noblis (Royal Pinks). Mixed colors

Punctatus (Princess Pinks). Many colors.

Salmon Oueen. Bright salmon shades.

Vesuvius. Bright Geranium-red, fine.

\section{Dracaena.}

It is always well to have a lot of these coming along, they are so useful as centre plants, etc. Seeds are sent out in the berry or hull, and should be rubbed out before sowing.

Tr. okt. Ox.

Indivisa. Narrow foliage. Very useful. i/4-lb. \$1.00 10 Lineata. Slightly broader than type. . $\quad 15 \quad 50$

Ferns.

We can furnish spores of the following varieties at the uniform price of 50 cents per trade packet.
Adlantum Cuneatum

Alsophila Australls

Aspldium Tsussimense

Blechnum Brazillensis

Occidentale

Cyrtomium Falcatum

Fortunel

Lomaria Gibba

Lastrea Arlstata Varlegata Chrysoloba

Polypodium Aureum

Polystichum Coreaceum Setosum

Finest mixed. A large number of sorts.

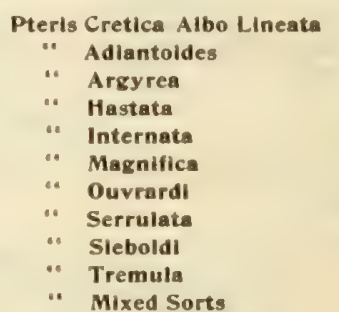

Sitalobium Cicutarium

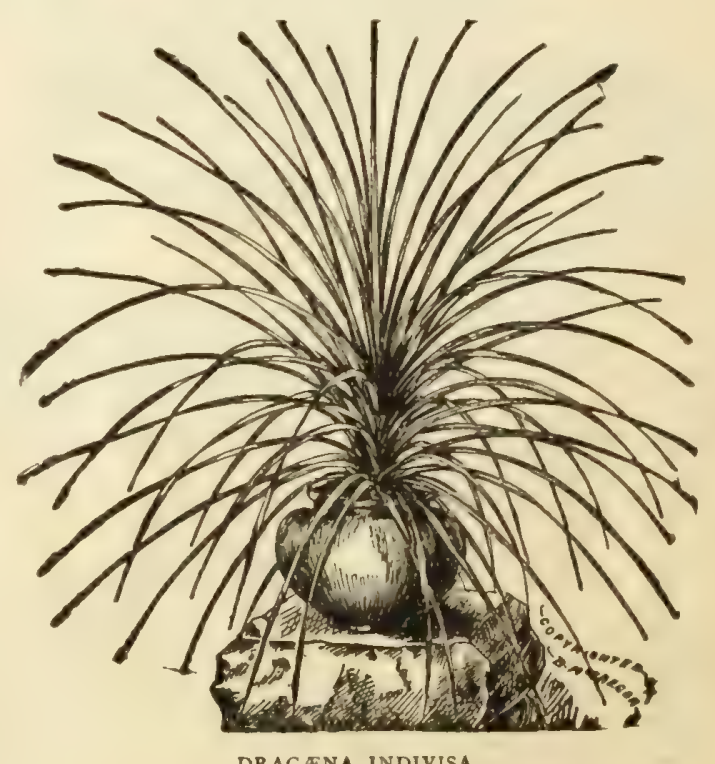

DRACAENA INDIVISA 


\section{Gaillardia.}

Useful for cutting, or for the mixed border

Amblyodon. Deep blood red.

Plcta. Crimson and orange.

Single annual. Mixed

Lorenziana. The Bride. Double creamy-white.

Lorenziana. Double mixed.

$\begin{array}{cr}\text { Tr. pkt. } & \text { Oz. } \\ 10 & \$ 0 \\ 10 & 15 \\ 10 & 15 \\ 30 & 150 \\ 10 & 20\end{array}$

\section{Grasses, Ornamental.}

These are now largely used in large beds as well as for isolated specimens. The Pennisetums are one of the very best plants to edge a bed of Cannas, Caladiums, or other tall-growing plants.

Agrostis Nebulosa.

(Cloud Grass) Tr. pkt.

Briza Maxima (Quaking Grass)

Coix Lachryma (Job's Tears) . . . . . 40 cts. lb.

Lagurus Ovatus (Hare's-tail Grass) -

Pennisetum Longlstylum

$$
\begin{aligned}
& \text { Rueppelianum (Purple Fountain Grass) } \\
& \text { Grevillea (Silk Oak). }
\end{aligned}
$$

\section{Grevillea (Silk Oak)}

Robusta. A highly ornamental foliage plant, useful in many ways, and easily and rapidly raised from seed

\section{Gypsophila.}

Elegans, Alba Grandiffora. A fine large flowering form of the annual Baby's Breath; fine for cutting. 50 cts. per $1 / 6-1 b$.

Muralis. Dwarf pink.

\section{Helianthus (Sunflower).}

Globosus Fistulosus (Dahlia Sunflower)

Nanus iI. Ol. (Globe of Gold)

Chrysanthemum-flowered. Double yellow

Cucumerifolius (Miniature Sunflower)

$$
\begin{aligned}
& \text { Grandiflorus Stella } \\
& \because
\end{aligned} \quad \begin{aligned}
& \text { Prion } \\
& \text { Nerkeo, Dwart. } \\
& \text { Dow miniature. Mixed varieties }
\end{aligned}
$$

\section{Ipomaea.}

Of the following the Moon Flower is one of the quickest growing and most popular of all summer climbers, and all florists should have it on hand.

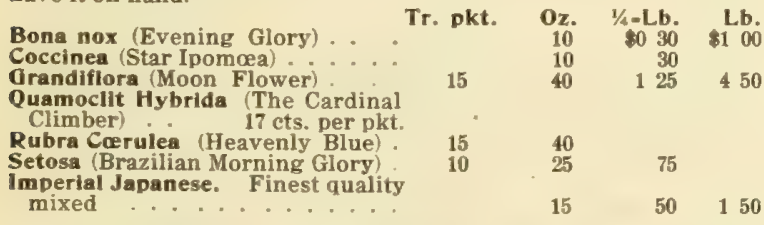

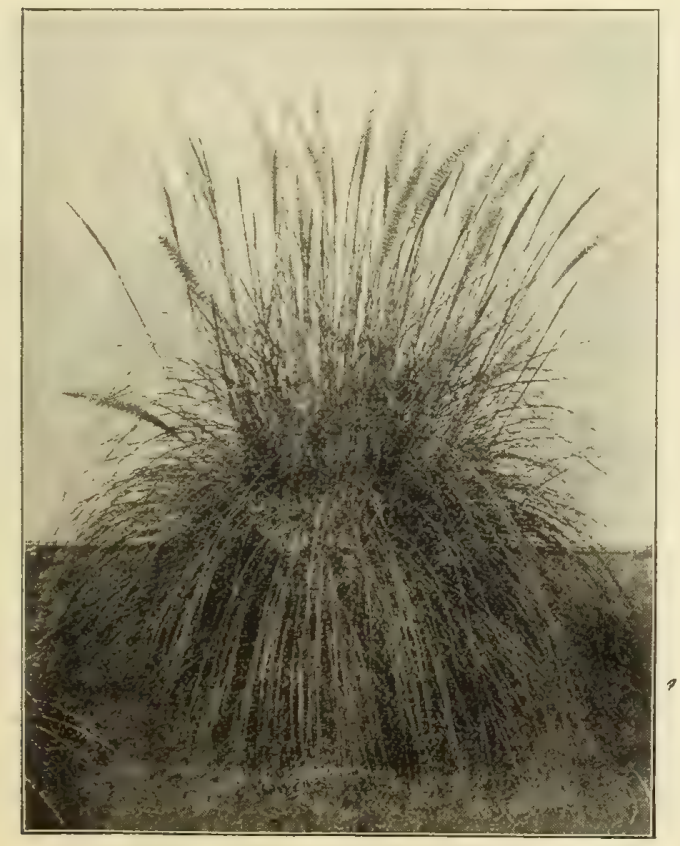

ORNAMENTAL GRASS PENNISETUM RUEPELLIANUM

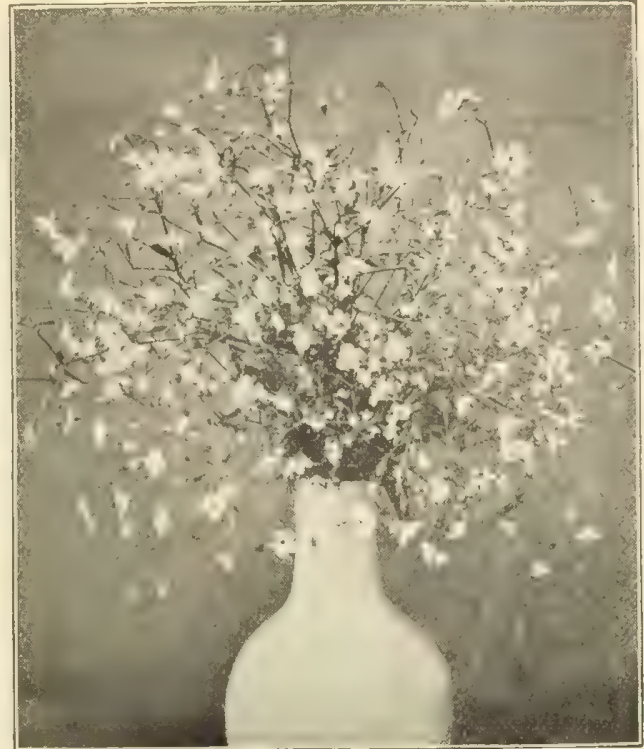

GYPSOPHILA ELEGANS ALBA GRANDIFLORA

\section{Heliotrope.}

Very easily raised from seed. Our stock comes from the best growers, and can be depended on to produce fine sorts.

emoine's Giant. Very large heads of bloom Regale. A dwarf-growing, large-flowering sort $\begin{array}{ccc}\text { Tr. pkt. } & \mathbf{O z} . \\ 40 & \$ 200\end{array}$ $\begin{array}{lll}\text { Regale. A dwarf-growing, large-flowering sort . . } & 40 & 200 \\ \text { Finest Mixed. The regular type. } & 25 & 100\end{array}$

\section{Larkspur (Annual Sorts).}

Splendid annuals for cutting; in bloom from mid-summer till

\begin{tabular}{|c|c|c|}
\hline & $c \mathbf{k}=\mathbf{f l o}$ & Dark blue. . \\
\hline s & & Lustrous carmine \\
\hline & .. & Shell=pink \\
\hline & $\because$ & Sky-blue. \\
\hline & $\because$ & $\begin{array}{l}\text { Tri-color } \\
\text { White }\end{array}$ \\
\hline & “. & Mixed. \\
\hline
\end{tabular}
frost.

\section{Lobelia.}

All of the varieties are used for bedding, vases, etc. The varieties Speciosa and Gracilis, are of a trailing habit and are specially suited for hanging baskets, etc. Seed should be sown early. It germinates easily and quickly but takes some time to get them any size.

Crystal Palace Compacta. Best dwarf, dark blue, dark foliage.

Emperor William. Dwarf, clear light blue.... Tr. pkt. Oz.

Hybrida Sapphire. New trailing variety blue white

eye ............. 17 cts. per pkt.

Prima Donna. Crimson

White Gem. White, compact

Gracilis. Light blue, trailing

Speciosa (Crystal Palace var.) Dark blue, trailing Heterophylla Major. A splendid clear blue bedding sort. Very large individual flowers

Tenuior. Very large flowering, rich blue, with white

Erinus compacta. All colors, mixed :

\section{Lupinus (Annual Sorts.)}

\section{Rich Blue}

Sky Blue

Rose

White

Mixed. $20 \mathrm{cts}$. per $1 / 4-\mathrm{lb}$

\section{Marigold.}

All are useful for many purposes.

African. Double, mixed

EI Dorado. Very double, orange

“. Lemon Queen. Lemon yellow

“ Orange Prince. The finest golden orange Pride of the Garden. A dwarf golden yellow the Garden. A dwarf golden

French, Double Dwarf. Mixed. . . . . . . . Gold Striped, Extra fine . . . .

" Legion d'honneur (Little Brownie.) A

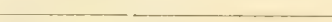




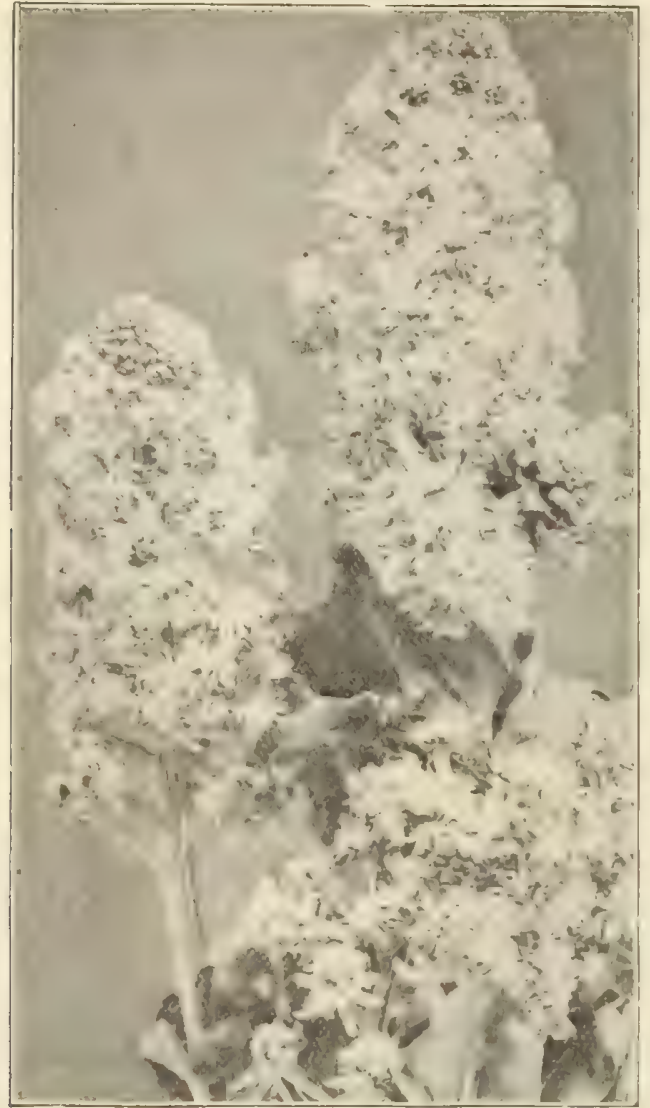

DEFIANCE MIGNONETTE

\section{Mignonette.}

For Florists' use we especially recommend the Defiance, Goliath and Machet. But all of the varieties offered are good and strictly select stocks.

Deflance, Very large spikes

Gollath. Giant spikes, extra fine.

Golden Machet.

Golden Machet. Fine

Machet. True select stock of this fine sort, $1 / 1 \mathrm{lb}, 75 \mathrm{c}$ Miles Hybrid Solral. A fine outdoor sort, $1 / 4 \mathrm{lb} .40 \mathrm{c}$ Orange Queen. Orange yellow

Parson's White

Salmon Queen. A very high colored kind

$1 / 4$ lb. 75 c.

Sweet-Scented, large flowering . . . $1 / 4 \mathrm{lb} .20 \mathrm{cts}$.

Tr. okt. Ox.

15 to

Myosotis (Forget-me-not).

Alpestris Royal Blue. Rich indigo-blue Robusta Orandifiora, Blue, large flower-

- Stricta Grandiflora. Upright grower, blue

- Stricta Grandiflora. Upright Mictoria Blue; very fine

Dissitiflora. Clear blue. Early fiowering

Palustris. True Forget-me-not Semperflorens. Ever-blooming
Tr. pkt, Oz.

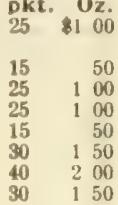

\section{NASTURTIUMS}

We sell immense quantities of both the Tall and Tom Thumb sorts. They are very effective in window boxes, vases, baskets, etc.

\section{Miscellaneous Nasturtiums.}

Dwarf Geranium-leaved. New, Scarlet Jvy-leaved. Mixed colors Variegated-leaved. Mixed color Lillput. Very compact, mixed colors

Tall Hybrids of Mme. Gunter. A splendid strain many fine and unusual colors

Iyy-leaved. Mixed colors

Variegated-leaved. Mixed colors

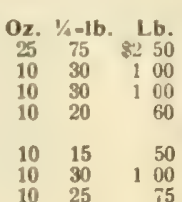

\section{Nasturtiums-Continued}

\section{Lobb's Tall Nasturtium.}

Asa Gray, Cream white.

Black Prince. Dark, velvety crimson, dark foliage Brilliant. Bright scarlet.

Cardinal. Intense geranium-red..

Crown Prince of Prussia. Blood red

Giant of Battles. Sulphur, red blotches.

Golden Queen. Pure golden-orange

Princess Victorla Loulse. Creamy white, orange scarlet blotches

Regina. Salmon red to cream.

Rol des Noirs (King of the Blacks). Very dark

Rudoloh Virchow. Fine ruby rose.

Sritfire. Vermilion scarlet.

Mixed. Lobb's varieties; fine

\begin{tabular}{rrrr}
\hline z. & $1 / 4-\mathbf{l b}$ & $\mathbf{L b}$ \\
$\mathbf{1 0}$ & 20 & $\mathbf{8 0}$ & 60 \\
10 & 20 & 60 \\
10 & 20 & 60 \\
10 & 20 & 60 \\
10 & 20 & 60 \\
10 & 20 & 60 \\
10 & 20 & 60 \\
10 & 20 & 60 \\
10 & 20 & 60 \\
10 & 20 & 60 \\
10 & 20 & 60 \\
10 & 20 & 60 \\
10 & 15 & 45
\end{tabular}

Tall or Climbing Nasturtiums.

Chameleon. Different colors on same plant . . $\quad \begin{array}{lll}10 & 20 & 50\end{array}$

Chocolate

Crimson. Very rich shade......................... 10

$\begin{array}{llll}\text { King Theodore. Deep crimson maroon, dark foliage } & 10 & 20 & 50 \\ \text { Lemon Yellow. } & 10 & 20 & 50\end{array}$

Lllac. An odd shade.

Orange. A fine deep shade.

Pearl. Creamy white.

Prince Henry. Cream spotted and tipped

Purple. Purplish crimson.

Rose. Fine color

Scarlet. Brilliant

Schulzl. Deep scarlet, dark foliage

Spotted. Yellow spotted crimson

Straw Striped Scarlet

Vesuvius. Salmon rose; dark leaved

Mixed. Best quality, $10 \mathrm{lbs} ., \$ 3.00$

Tom Thumb or Dwarf Nasturtiums.

Aurora. Salmon and pink.......... $10 \quad 20 \quad 50$

Beauty, Yellow striped red . . . $10 \quad 20 \quad 30$

Bronze ..................... $1020 \quad 50$

Chameleon. Various colors on one plant. $\quad 10 \quad 20-50$

Cloth of Gold. Scarlet, yellow foliage. . . . $\quad \begin{array}{lll}10 & 20 & 50\end{array}$

Crystal Palace Gem. Sulphur spotted maroon. . $\begin{array}{lll}10 & 20 & 50\end{array}$

Empress of Indla. Bright crimson, dark leaved. $\begin{array}{llll}10 & 20 & 60\end{array}$

Golden King. Golden yellow. . . . . . . $10 \quad 20 \quad 60$

King of Tom Thumbs. Dark scarlet, dark leaved $10 \quad 20 \quad 60$

King Theodore. Deep maroon, dark leaved. . $\begin{array}{lll}10 & 20 & 60\end{array}$

Lady Bird, Orange, spotted red........ $10 \quad 20 \quad 50$

Pearl. Creamy white ..... $10 \quad 20 \quad 50$

Prince Henry. Creamy white spotted and tipped red $\begin{array}{lll}10 & 20 & 50\end{array}$

Regellanum. Purplish crimson . . . . . . . $1020 \quad 50$

Rose. Fine soft rose............ $1020 \quad 50$

Ruby King. Ruby rose............ $10 \quad 20$

Spotted. Yellow spotted red.......... $10 \quad \begin{array}{lll}20 & 60\end{array}$

Vesuvius. Salmon rose, dark leaved...... $\begin{array}{llll}10 & 20 & 60\end{array}$

Mixed. Best quality . . . . . 10 lbs., $83.50 \quad 10 \quad 15 \quad 40$ 


\section{Dreer's Perfect Pansies}

We fully realize the importance of sending out only the best qualities of Pansies. Our stocks are received from careful growers and are not surpassed either for quality or germination.

Tr. pkt. Oz.

Dreer's Royal Exbibition. This is our finest mixture. It comprises a wonderful variety of colorings, flowers of largest size, of perfect form and texture. $1 / 8$ oz., $\$ 1.25$

Dreer's Premium. This mixture comprişes a large number of colorings and is intended to supply the want of a first-class mixture at a moderate price.

Cassler's Giant. A grand mixture of the finest blotched varieties, splendid in every way.

Masterplece (Frilled Pansy). A remarkable type, each petal being conspicuously curled or waved. The range of color is very extensive; the rich, dark velvety shades predominating

Mme. Perret. A beautiful strain; flowers of largest size and borne very freely in great diversity of colors; especially rich in red and wine shades. The stock we offer comes direct from the introducer.

Oiant Trimardeau. Of strong, robust growth with very large flowers in a good range of colors.

Glant Parisian. Of very large size, and containing a great many fancy colors and color combinations

English Finest Mixed. A very fine mixture

Good Mixed. All colors.

\section{Pansies in Separate Colors.}

Cardinal. The brightest red

Emperor William. Ultramarine blue.

Faust or KIng of the Blacks. Black purple

Kaiser Frederick. Velvety brown, edged red and

yellow. Very rich

Lord Beaconsfield. Purple shading to white

Lord Beaconsfie

Mahogany Color a blaret and white

Peacock. Blue, claret and white
Psyche. Purple violet, edged white

Psyche. Purple violet, ed

Snow Queen. Pure wh

Yellow, with dark eye

Yellow Gem, pure yellow

Olant Adonis. Lavender blue

Emperor Willam. Bright blue

* Fire King. Purple and gold, fine

* Freya. Rich wine color, edged white

“ Golden Queen. Rich pure yellow

* Lord Beaconsfleld. Purple, shading to white

a Prince Henry. Royal blue

- Prince Henry. Royal blue

Rain

is Snow Que

White, with" dark eye

a Yellow, with dark eye

1. Trimardeau. Finest Mixed. All colors

50

50

50

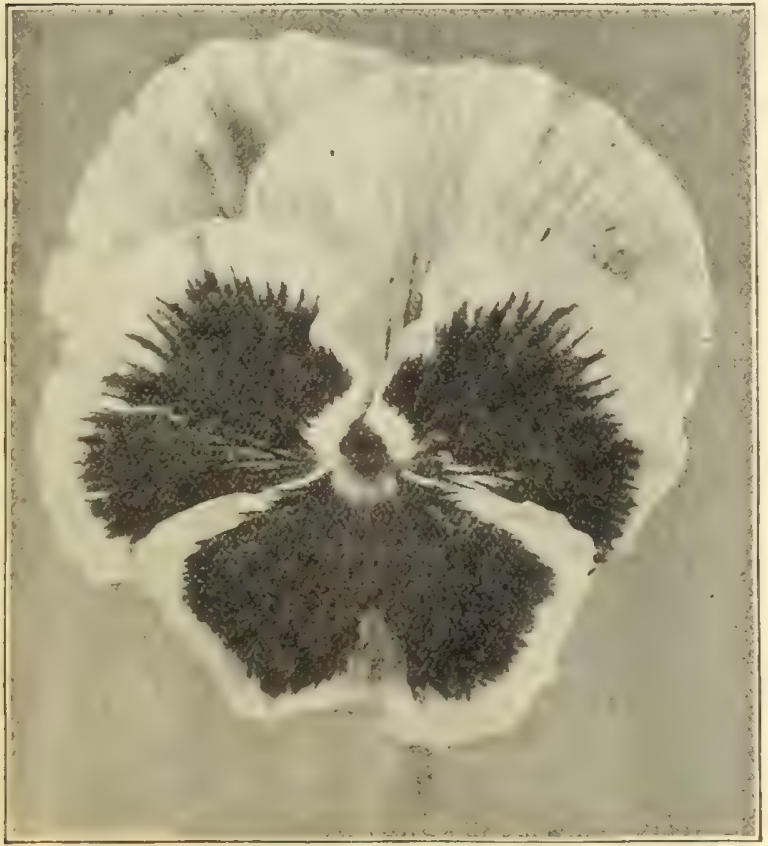

DREER'S ROYAL EXHIBITION PANSY

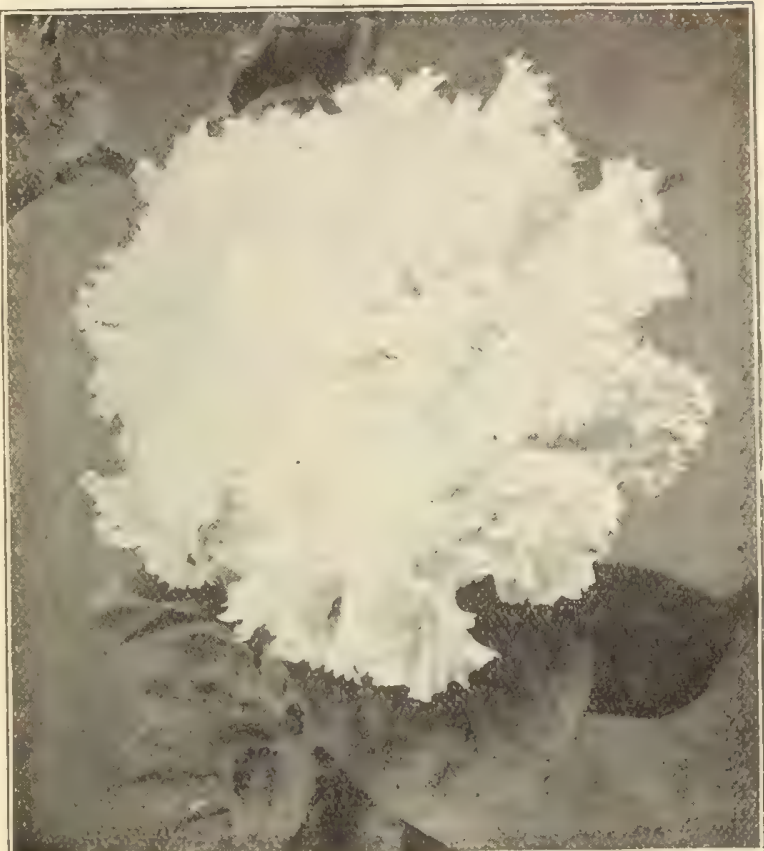

DREER'S DOUBLE FRINGED PETUNIA

\section{Dreer's Superb Petunias}

Our Riverton grown strain of Double and Single Fringed Petunia have long been celebrated as the best on the market. We keep continually culling out and hybridizing and thus maintain the high standard. We frequently test stocks from the world's best growers and can say, without fear of contradiction, that our own strain is by far the best to be had at any price.

Note.-We would esperially call the attention of every florist who grows Double Petunias from seed that all the smallest and weakest seedlings should be saved, as they usually produce the finest double flowers. The same is true of the singles, the strong seedlings being inclined to "weediness."

Dreer's Superb Double Fringed. Our own unrivaled strain. Every seed saved at Riverton. Mixed colors. 75 cts. per 500 seeds; $\$ 1.50$ per 1000 seeds.

Dreer's Superb Double Fringed White. Saved from the finest type of fringed pure white, carefully hybridized. $\$ 1.00$ per 500 seeds.

Double Fringed Imported. Seeds are saved by one of the foremost European growers; the best that can be had abroad. $\$ 1.00$ per 1000 seeds.

Dreer's Superb Single Fringed. All our own saving from the finest large fringed flowers. Mixed colors. 50 cts. per tr. pkt. $\$ 1.00$ per $1 \frac{2}{16}$ Oz; $\$ 1.50$ per $1 / 60 z$.

Dreer's Superb Single Fringed White. $50 \mathrm{cts}$. per trade pkt.

Giant of California
Ruffled Giants Saved by an expert Tr. pkt.

Fringed Ruffled Giants $\}$ in California.

Howard's Star. A beautiful and useful variety. The flowers are of medium size, of a rich crimson maroon, with a blush white stripe through each petal, forming a five-pointed star. Just the thing for filling boxes, vases, etc. 30 cts. per trade pkt.; $\$ 1.50$ per $0 z$

Dwarf Inimitable. Cherry red and white Snowball. Pure white

Brilliant, Carmine pink, fine bedder Rosy Morn. Soft pink, white throat

Striped and Blotched. Finest mixed; small flowering, but very free. Grand for massing for effect. Hybrida. Pure White. Good for massing Hybrida. Pure White. Good for massing

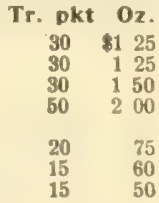

\section{Pentstemon.}

Gentianoides grandiflorus. "Sensation." This beautiful variety is being largely used for bedding. It comes in a good range of colors, such as rose, red, pink, lilac, mottled and spotted. Should be handled in the same way as Petunias, Verbenas, Salvias, etc. 


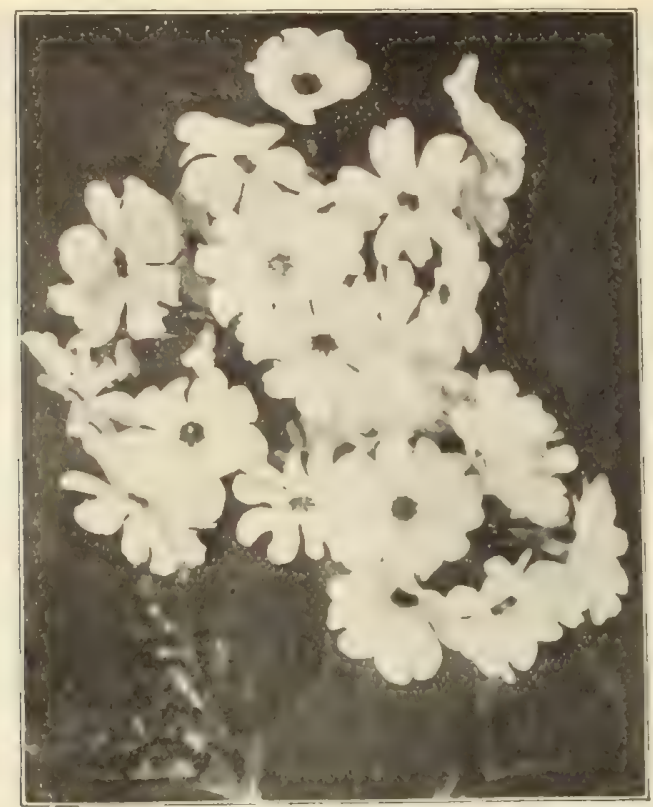

PRIMULA OBCONICA GRANDIFLORA

\section{Phlox Drummondi.}

These are fine summer flowering annuals. The Large Flowering Dwarf and Nana Compacta make excellent pot plants for spring sales.

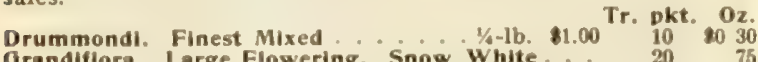
Orandiflora. Large Flowering. Snow White $\quad 10 \quad 2030$ Shell-pink $20 \quad 75$ Deep Rose Primrose Soft Lilac Rich Crimson Bright Scarlet Finest Mixed

Large Flowering Dwarf White

$\because$ \#

Nana Compacta Snowball

". Fireball Mald, soft pini

$\because \quad$ is Mair Maid.

Doubie Mixed

Star of Ouedlinburg. Mixed.

\section{Primula.}

The most important member of this family to the florist is the Fringed Chinese Primrose. Our supoly of which we procure from the best sources, and sure to give the same satisfaction in the future that it has in the and The Obconica varieties are also very popular. making beautiful pot plants for winter blooming.

\section{Fringed Chinese Varieties.}

Alba Magnifica. Extra fine fringed white Covent Garden Red. A fine bright red Covent Garden White. The freest flowering pure white

Holborn Btue. An odd shade

Rosy Morn. A fine pink

Stellata. Fine decorative variety. Mixed colors Dreer's Choicest Mixed. Made up of the finest named varieties; the best procurable
Tr. pkt.

75

75

75

75

75
Obconica Varieties.

A solendid free-flowering type. The Grandiflora varieties have fine large flowers and are very free blooming. The Giganteas have still larger flowers, but are not quite so free.

Grandiflora Alba. Pure white. $14 \mathrm{cts}$, per pkt.

Tr. pkt.

Apple-blossom. Soft pink. 14 cts. per pkt

Kermesina. Crimson. 14 cts. per pk

Rosea. Clear rose. 14 cts. per pkt.

Crispa. New form with wavy petals. 17 cts. per pkt.

Finest Mixed. All colors. 75 cts. per $1 / 00$

Rich crimson. 17 cts, per plst.

Rosea. Fine rose, $17 \mathrm{cts}$, per pkt.

Cholcest Mixed. $\$ 1.00$ per 700 .

\section{Various Primroses.}

Floribunda. Yellow

Forbes! (Baby Primrose)

Malaceoldes. Free-flowering

Alba. Pure white. 17 cts, per pkt.

Tr. pkt.

50

Ricinus (Castor Oil Bean)

Magnificent tropical looking plants. Make splendid ornaments for the lawn or in large beds. Always a good demand for them in for the lawn or in large beds. Always a good demand for them in pots or out of fiats,

Gibsont. Gibsoni. Dark red, metallic lustre, 6 feet
Philippinensis. Large purplish foliage. 10 feet Sanguineus. Red stems, green foliage. 8 feet. Zanzibariensis. The most tropical looking of all Gigantic leaves
Mixed. All sorts.

$10.25, \quad$ Lb. $10 \quad 25 \quad 75$ $10+25 \quad 75$ $10 \quad 20 \quad 50$ $\begin{array}{lll}10 & 20 & 50 \\ 10 & 15 & 40\end{array}$

\section{Salpiglossis.}

Useful summer flowering annuals with very showy flowers,

Improved Large Flowering Finest Mixed Emperor. Very large flowering, mixed color

Tr. pkt. Oz. Salvia (Sage).

The "Scarlet Sage" stands very near the top in popular bedding plants. We only offer the finest types, each being quite distinct.

$$
\begin{aligned}
& \text { Splendens. "'Scarlet Sage," Bright scarlet ". Ball of Fire." A splendid dwar' sort. } \\
& \text { "Zurich." New dwarf, very early flow- } \\
& \text { ering } \\
& \text { Bouquet Rose." New rose pink variety, } \\
& 17 \text { ets. per pkt. } \\
& \text { Patens. Blue Salvia. }
\end{aligned}
$$$$
\text { Burning Bush" " Of toller growth than } 40
$$$$
\text { the above. Very large spikes. } 40 \quad 200
$$$$
50 \quad 400
$$$$
60 \$ 00
$$

Scabiosa (Mourning Bride, Sweet Scabious).

Very desirable for summer cut nowers. Useful in making up.

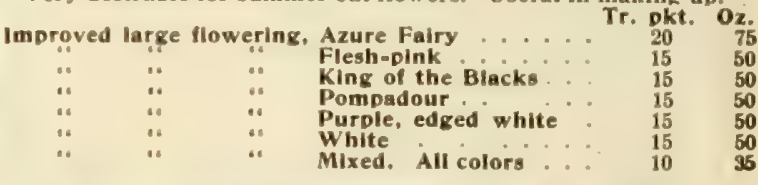

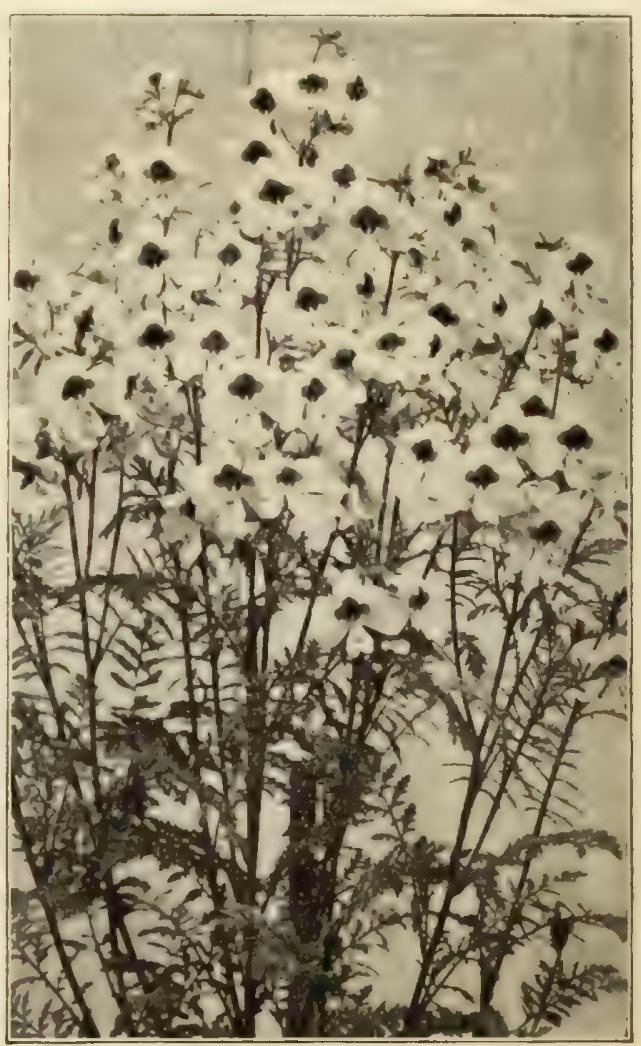

SCHIZANTHUS DWARF LARGE-FLOWERED (See page II) 


\section{Schizanthus.}

(Butterfly or Fringe Flower)

This is one of the airiest and daintiest flowers imaginable. They make admirable pot plants for late winter and early spring. For this purpose sow in the autumn. At the International Flower Show held in London in May last year they were easily one of the most effective flowering plants in the exhibition.

Dwarf Large-Flowered. A grand variety, forming compact pyramidal plants, literally covered with large, beautiful, orchid-like
flowers in a bewildering range of color. $25 \mathrm{cts}$. per trade pkt.; $\$ 1.00$ per oz.

Wisetonensis. White, dotted with delicate rose. $40 \mathrm{cts}$. per trade pkt.; $\$ 2.00$ per oz.

\section{Smilax.}

Every florist should grow some of this, always needed. Seed we offer is of new crop and of high germination. Tr. pkt., 10 cts.; $\mathbf{0 z}$. 35 cts.; $3 / 4-16 ., 81.00$.

\section{Solanum.}

Tr. pkt. $0 z$.

Capsicastrum (Jerusalem Cherry). There is always a demand for red berried plants around Christmas and this is the most popular of all. Sow early to get good sized plants

Fre Diavolo. A new variety of dwarf, compact

Frowth, with smaller foliage and fruit than the type

Stevia.

Serrata. An old favorite white flower, still used extensively for cutting

\section{Stocks (Gilliflower).}

Thousands of Stocks are sold as pot plants, and many more are grown for their flowers. Cheap grades are likely to prove largely single. Ours are grown specially for us by an expert, and will produce over 90 per cent. double flowers.

\section{Cut-and-Come-Again Ten Weeks' Stocks.}

Splendid perpetual-blooming class; sown in March or April they begin flowering in July, continuing until frost, and are especially valuable during September and October when other flowers are scarce; they throw out numerous side branches, all bearing very double fragrant flowers; excellent for cutting. Tr. pkt. Ox. Princess Alice, Snow-white . . . . . . . . Tr. pkt. $\$ 300$ La France. Silvery rose ............ 50 . 300 Brilliant. Fiery blood-red................. 500300

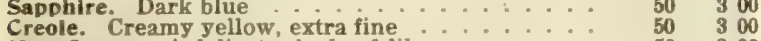

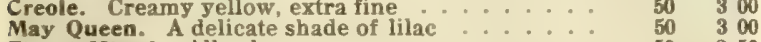
Finest Mixed. All colors ............. 50250

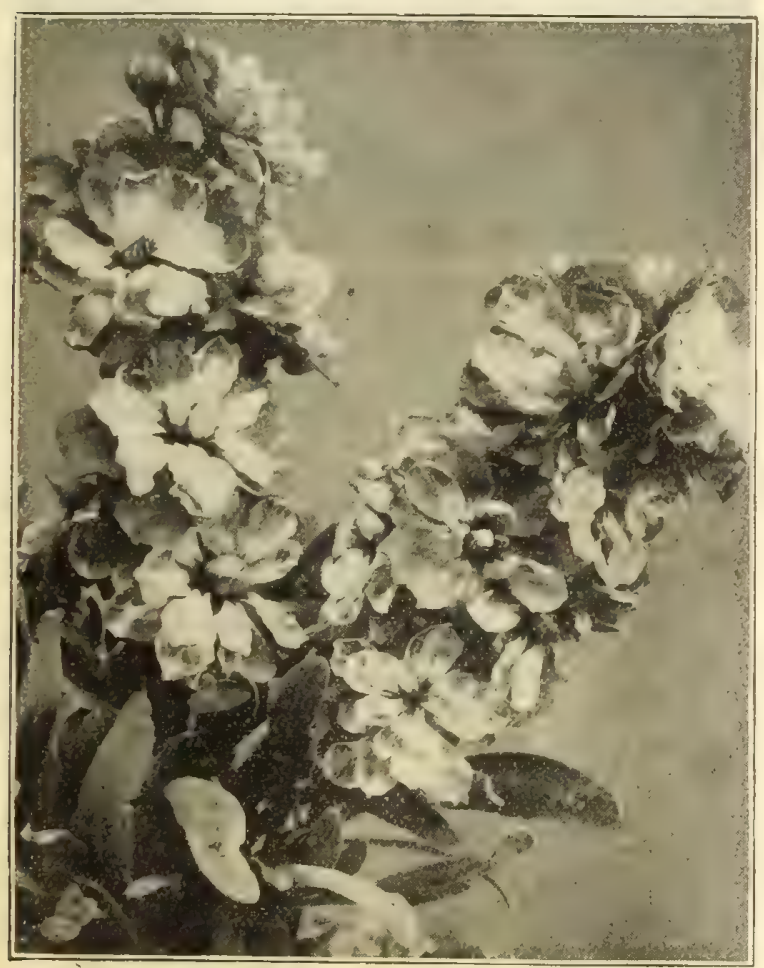

CUT-AND-COME-AGAIN STOCKS

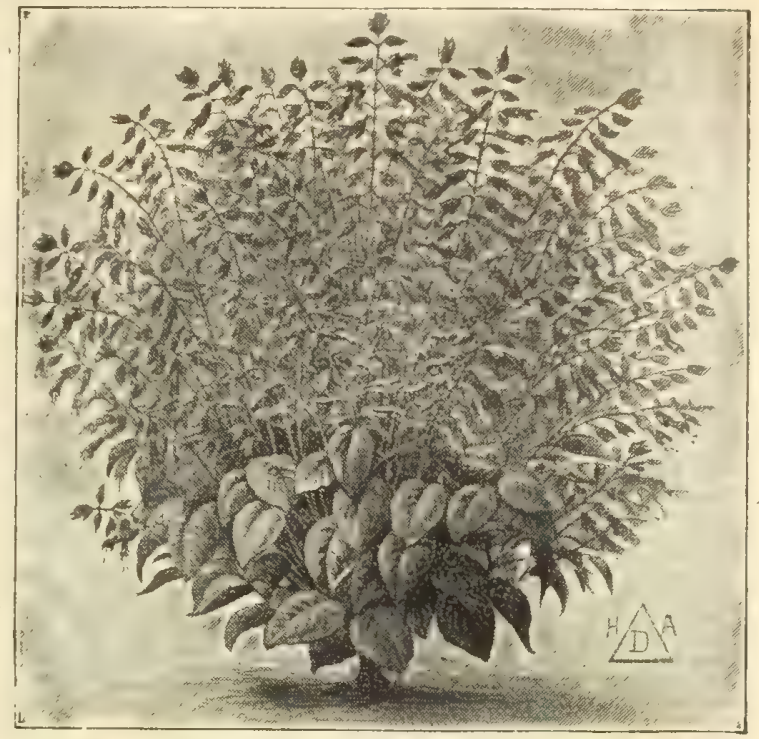

SALVIA "B̈ONFIRE" (See page IO)

Stocks-Continued.

Large Flowering 'Ten Weeks' Stocks.

This is the leading variety for bedding. of dwarf, compact habit. Comes into bloom early and produces fine spikes of very double flowers.

\section{Blood red}

Canary yellow

Bright rose

Light blue

Purple

Pure white.

Tr. pkt. $0 \mathrm{z}$. $\begin{array}{rrr}40 & \$ 2 & 50 \\ 40 & 2 & 50\end{array}$ $\begin{array}{lll}40 & 2 & 50 \\ 40 & 2 & 50\end{array}$ $40 \quad 250$ $40 \quad 250$

Finest mixed

Varieus Stocks.

Wallflower-leaved, Ten Weeks' Snowflake. A fine

white

Beauty of Nice. Delicate flesh-pink

Empress Elizabeth. Brilliant carmine-rose

Queen Alexandra. Rosy-lilac, fine for cutting

Brompton. Mixed.

Sweet Peas (See page I 2 ).

\section{Verbenas.}

We take special pains with our strain of Mammoth Verbenas, continually selecting and keeping it up to the highest point for size of flowers, purity of color, ete. They should be sown early to get nice plants in time for spring sales.

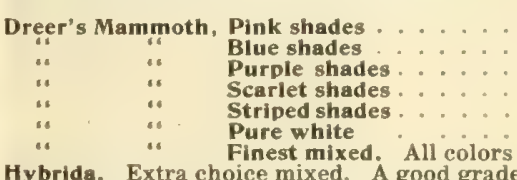

Hybrida. Extra choice mixed. A good grade Lemon (Aloysia Citriodora)

Venosa. Purplish heliotrope. Fine bedder

Erinoides. Deep lavender. Fine for baskets, etc

\begin{tabular}{rrr} 
Tr. pkt. & \multicolumn{1}{c}{$\mathbf{0 z}$} \\
30 & 125 \\
30 & 125 \\
30 & 1225 \\
30 & 125 \\
30 & 125 \\
30 & 125 \\
35 & 1 & 00 \\
& 25 \\
15 & 50 \\
30 & 150 \\
10 & 25 \\
15 & 50 \\
15 & 50
\end{tabular}

\section{Vinca.}

Most useful plants. Seeds should be sown early in brisk heat.

Rosea. Rose, with darker eye

Alba. White, with rose eye “ Delicata. New, soft rosy carmine. 14 cts. per

. Mixed. All colors

$\begin{array}{lr}15 & \$ 050 \\ 15 & 50\end{array}$

Viola (Tufted Pansies).

Cornuta Papilio (Butterfly Violet). Blue Lutea splendens. Clear yellow Blue Perfection. Deep blue White Perfection. Fine white Hybrida Admirabilis. Thuringia. Rich blue, white eye. New. 14 ets. per pkt.

Mixed. All colors

40200

$\begin{array}{lll}30 & 1 & 25 \\ 30 & 1 & 50\end{array}$

30150

$40 \quad 200$

$25 \quad 100$ 


\section{Dreer's Fine Sweet Peas}

We only offer the very best varieties. Those marked * are the kinds best suited for Florists for cutting.

\section{Orchid-flowered Sweet Peas.}

This type is distinguished from the standard sorts by the extraordinary size of their flowers and by the standard being crinkled and wavy. They usually bear four blossoms on a stem, and are as easy to grow as the commonest sorts. Owing to their being shy seeders they will always be higher in price than the standard sorts.

Asta Ohn. Soft lavender tinged mauve

*Apple Blossom Spencer. Rose and pink

Aurora Spencer. White, striped orange-salmon

Black Knight Spencer. Rich maroon

* Blanche Ferry Spencer. Pink and white

* Countess Spencer (true). A lovely clear pink

Dainty Spencer. White edged rosy pink

"Florence M. Spencer. Delicate blush with pink

"Frank Dolby. Largest pale lavender

Gladys Unwin. Charming pale rose pink.

George Herbert. Rich, rose carmine.

Helen Lewls. Brilliant orange rose.

King Edward Soencer. Crimson scarlet

Mrs. Routzahn Spencer. Soft chamois pink

Mrs. Walter W right Spencer. Deep mave

Mrs. Walter Wright Spencer. Deep

* Primroge Spencer Primrose or c....

Primce of

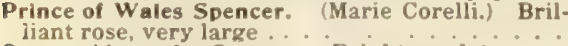

Queen Alexandra Spencer. Bright scarlet

* White Spencer. A pure white Countess Spencer of very large size

orchid-Fiowered Mixed

\section{Standard Varieties of Sweet Peas.}

The sorts marked * are the kinds best suited for florists for cuttin

Aurora. White flaked with orange salmon

Black Knight. Black maroon

*Blanche Ferry. Pink and white

Coccinea. Rich cerise, very bright

Dainty. White, edged with oink

* Dorothy Eckford. The finest white

Dorothy Eckford. The "

Duke of Westminster. Clear purp

* Emily Henderson. Purest white

*Flora Norton. The clearest bright blue

Helen Plerce. White veined, bright blue...

Hon. Mrs. E. Kenyon. The finest primrose yellow

Jeannie Gordon. Rosy pink on a cream ground

Katherine Tracy. Briliant pink.

* King Edward VII. Rich deep crimson scarlet

Lady Orisel Hamilton. Pale lavender.

*ord Nelson. Rich navy blue

Lottie Eckford. White suffused with lavender

* Lovely. Shell pink, extra fine.

Midnight. Indigo and maroon. Very dark.

Miss Willmott. Rich, deep orange pink

* Mrs. Walter Wright. Deep mauve.

*Prima Donna. Deep pink fine.

* Prince of Wales. Deep rose.

Oueen Alexandra. The nearest to a pure scarlet.

Q Queen of Spain. Charming shade of chamois pink

St. George. Brilliant orange scarlet.

\section{Early Flowering Sweet Peas.}

Earliest of All, or Christmas Pink. Pink and white. 10

Earlest of All, or Christmas Pink. Pink and white. 10

Mrs.

Mrs. Alex. Wallace, Rosy lave

Mrs. C. H. Totty. Lavender
Mrs. F. J. Dolansky. Pure pink

Mrs. F. J. Dolansky, Pure pin

Mrs. W. W. Smalley. Chamois pink

Mrs. E. Wilde. Bright rose

Le Marquis. Rich, deep blue

\section{Mixtures of Sweet Peas.}

We take special pains in making up our various mixtures; nothing but named sorts are used.

Dreer's Peerless Mixture, contains only the finest grandiflora varieties the best mixture of standard sorts possible. Per $10 \mathrm{lbs}$. \$5.50

Orchid-flowered mixed. A splendid mixture, contain-

ing most of the varieties, besides a number of seedings of Countess Spencer.

Plnk shades. Mixed

Red shades. Mixed

Lavender and blue shades. Mixed

Lurender and blue shades. Mixed

Purple and maroon shades. Mixed.

Striped shades. Mixed

Cupld or Dwarf. All colors mixed

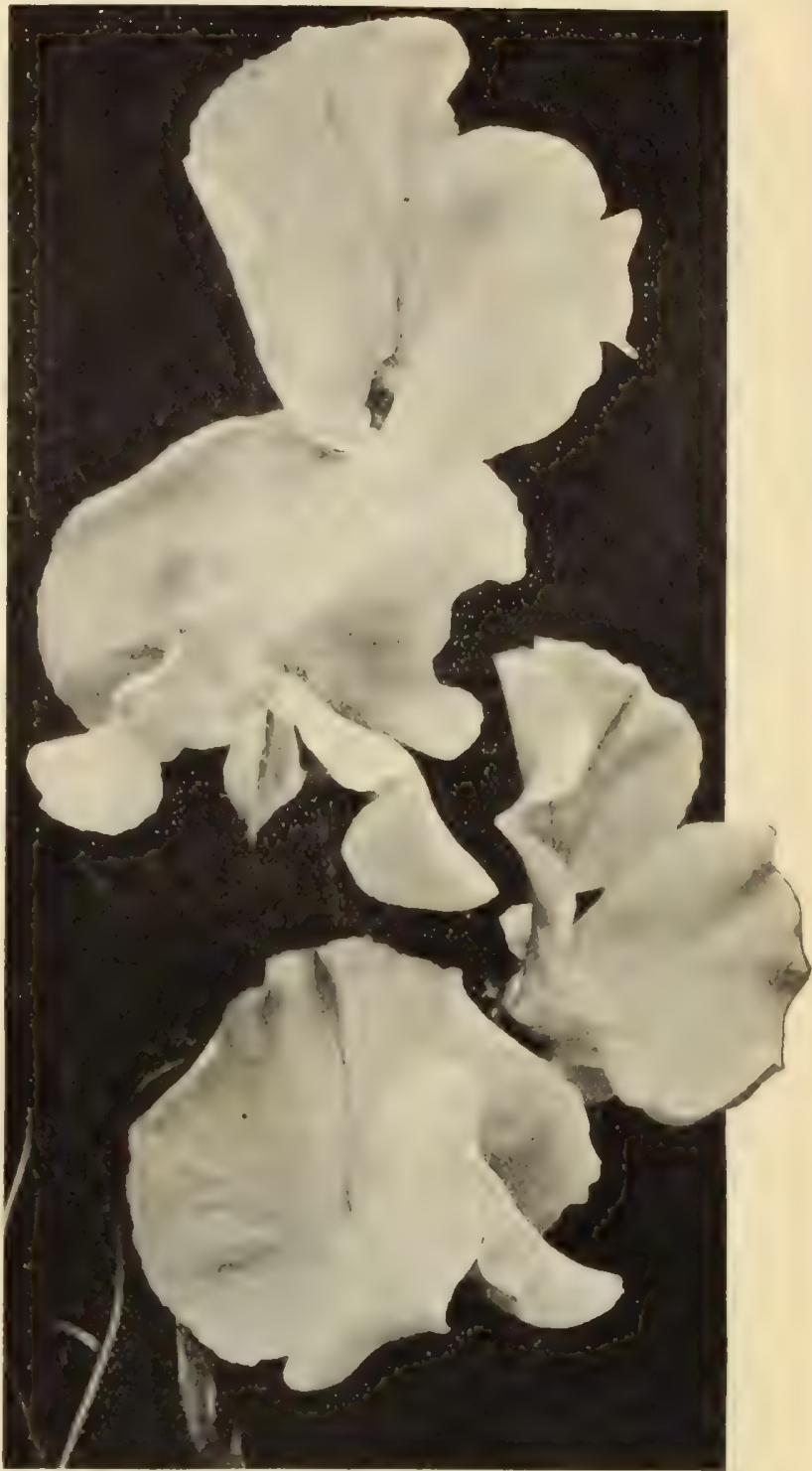

SPRAY OF ORCHID-FLOWERED SWEET PEAS

Zinnia (Youth and Old Age).

There is always a good demand for plants of these in the spring. and as cut flowers through the summer they are invaluable.

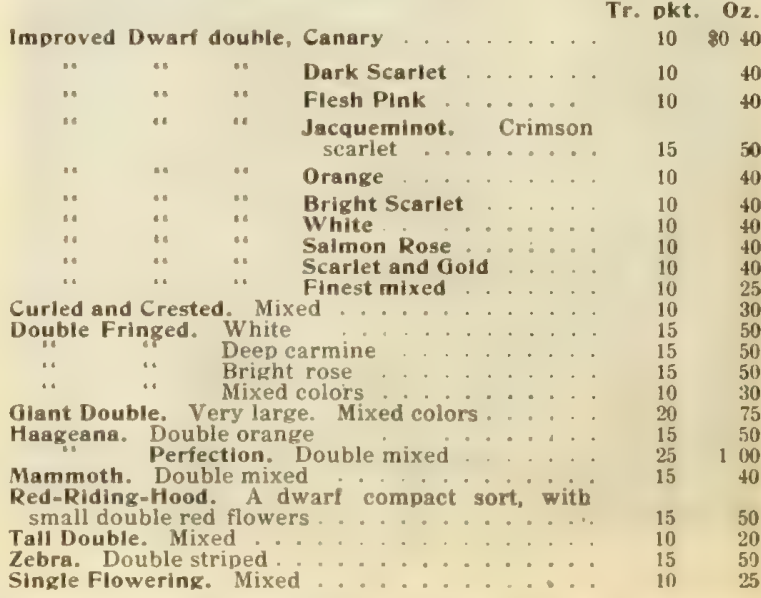


Condensed List of Garden and Greenhouse Flower Seeds

Tr. pkt. Per oz.

ABUTILON. Choicest mixed.

ACACIA. Finest mixed

ACROCLINIUM. Single. Mixed Double. Mixed

ASPERULA. Azurea setosa

AMARANTHUS, Caudatus (Love-lies-bleeding) Cruentus (Prince's Feather

Sunrise. Brilliant carmine

Salicifolius (Fountain Plant)

Tricolor (Joseph's Coat)

ARTEMISIA Saccorum Viridis (Summer Fir)

ARTEMISIA. Saccorum Viridis (S

BRACHYCOME. Iberdifolia. Mixed

BRAWALLIA. Speciosa major

Elata. Blue,

CACALIA. Coccinea. Mixed

CALCEOLARIA. Hybrida Grandiflora. Finest mixed. All colors

Tigrina. Choicest spotted and tigered

CANARY BIRD VINE (Tropaeolum canarienese). A

fine climber. 50 cts. per $1 / 4 \mathrm{lb}$.

CANNA. Egandale. Currant red.

Florence Vaughan. Yellow spotted

J. D. Eisele. Brilliant scarlet

Mime. Crozy. Scarlet. Gilt edge

Mime. Crozy. Scar

Richard Wallace. Clear yellow

Richard Wallace. 1 . 1.00 per $1 \mathrm{~b}$; $30 \mathrm{cts}$. per $1 / 4 \mathrm{lb}$.

CLARKIA. Elegans FI. PI. Alba. Double white Salmon Queen. Double salmon. Scarlet Queen. New

CLEOME. Gigantea

CONVOLVulus. Major.'Mixed (Moming Glory) 30 cts. per lb.

Major Double Flowering. Mixed.

Minor Roseus superbus

Mixed (Dwarf Morning Glory)。30 cts. per lb.

CUPHEA. Platycentra.

CYPRESS VINE. Scarlet

Scarlet. Ivy-leaved.

White

Mixed

CYPERUS. Alternifolius (Umbrella Plant)

DAHLIA. Single. French Collerette Colossal. New

Twentieth Century

Giant Perfection

Single. Mixed. All colors

Double. Large-flowering. Show varieties Cactus, Best Mixed

DATURA. Arborea Simplex (Brugmansia Cornucopia (Horn of Plenty)

Fastuosa Huberiana. Mixed colors Double Golden

DIDIscus. Coeruleus

DIMORPHOTHECA. Aurantiaca (Afriean Orange Daisy)

New Hybrids. "Various" colors

Dolichos. Daylight. Pure white. $25 \mathrm{c}$. per $2 / 4 \mathrm{lb}$ Darkness. Deep purple. 25 cts. per $1 / 61 \mathrm{lb}$ Lablab. Mixed. 20 cts. per $1 / 4 \mathrm{lb}$.

ECHINOCYSTIS. Lobata. 50 cts, per $1 / 4 \mathrm{lb}$.

ESCHSCHOLTZIA. Californica. Bright yellow

Callfornica Alba. Pure white

$$
\text { Aurantiaca. Orange }
$$

Carmine King. Purple carmine

Cross of Malta. Yellow orange bloteh

Dainty Queen. Pale coral pink

Gainty Queen, Pale coral pink

Golden West. Very large golden yellow

Mandarin. Orange and scarlet.

Single. Mixed.

Double. Mixed
EUPHORBIA. Variegata (Snow on the Mountain)

FUCHSIAS. Mixed. Single and double. 25 cts. per 100 seeds ; 82.00 per 1000 seeds

GAURA. Lindheimeri

GERANIUM. Applemscented. $25 \mathrm{cts}$. per 100 seeds $\$ 2.00$ per 1000 seeds

Pelargonium. Fancy. 75 cts. per 100 seeds

Zonale. Single mixed

GLOBE AMARANTH. Aurea superba. Yellow Nana compacta. A dwarf red.

Mixed. All colors

GLOXINIA. Hybrida grandiflora. Choicest mixed GOURDS. African Pipe.

Apple=shaped

Bottle-shaped

White Egg

Hercules'Club

Orange

Pear=shaped

Dish-rag or Sponge

Spoon

Turks' Turban

Warted

Mixed. 30 cts. per $1 / 4 \mathrm{lb}$

GoDETIA. Brilliant. Carmine rose

Duchess of Albany. White
8200

30
10
10
10
10
10
10
30
15
10
15
10
15
50
15
15
10
75
75
10

$10 \quad 20$

25

15

15

200

15
50

10

50

50

40

25

0

15
15

15
15
15
GODETIA. Gloriosa. Rich blood-red

Rosam

HELICHRYSUM" "Monstrosum. Double-mixed

HIBISCUS Giant Yellow or Golden Bowl

HUMULUS. Japonicus (Japan Hop)

Japonicus Variegatus

HUNNEMANNIA. Fumariaefolia (Giant Yellow Tulip Poppy)

IMPATIENS. Sultana (Sultan's Balsam)

Holstil Hybrids, Various color

JACOBAEA. Elegans f1. pi. Mixed colors

KOCHIA. Trichophylla

LANTANA. Hybrida. Finest mixed

LEPTOSIPHON. French Hybrids. Mixed colors

LINUM. Grandiflorum rubrum.

LOPHOSPERMUM. Scandens

LUNARIA. Biennis alba. .

MARVEL OF PERU. Mixed (Four O'clocks).

MATRICARIA. Capensis fi. pl. Double white

MATTHIOLA. Bicornis

MAURANDIA. Barclayana. Mixed

MESEMBRYANTHEMUM, Crystallinum (Ice Plant) Tricolor. Mixed (Wax Plant)

MIMosa. Pudica.

MIMULUS. Moschatus (Musk Plant)

Tigrinus. Mixed (Monkey Flower)

MINA. Lobata. Climber

Sanguinea. Climber

MOMORDICA. Balsamina (Balsam Apple)

Charantia (Balsam Pear) Banana). 1.00 per 100
USA. Ensete Abysinian Banana).

MUSA. Ensete Abyssinian Ban

NEMOPHILA. Mixed (Love Grove)

NICOTIANA. Affinis

Sylvestris

Sanderea Hybrids

NIEREMBERGIA. Frutescen

NGELLA. Damascena. Double mixed

Miss Jekyll. A beautiful clear blue

ENOTHERA. Annual varieties. Mixed

OXALIS Rosen

Tropaeololdes (Corniculata)

PHASEOLUS. Muitiflorus Papilio (Butterfly Runner Bean). $25 \mathrm{cts}$. per $1 / 4 \mathrm{lb}$.

Tr. pkt. Per oz.

$10 \quad \$ 030$

10

20

PORTULACA. Single Largeflowering

$$
\text { Rose . }
$$

Scarlet

White

Yellow
Mixed

Double Large-flowering. Mixed

PYRETHRUM. Aureum (Golden Feather) Aureum Selaginoides

RHODANTHE. Mixed

RUDBECKIA. Bicolor Superbs

Bicolor Superba Plena. Double

SANVITALIA. Procumbens fl. pl.

SAPONARIA. Vaccaria. Satiny pink

SMILAX. 1/4 lb., \$1.00

STEVIA. Serrata

TAGETES. Signata pumila

THUNBERGIA. Mixed. All colors

TORENIA. Fournieri. Blue

VISCARIA. Cardinalis. Bright red Oculata. Mixed

WALLFLOWER. Single Goliath. Velvety brown Single Extra Early Paris Double. Mixed

10

20

20

40
10

25

250

250

10
20

20
25
10

10 


\section{Hardy Perennial Flozuer Seeds}

Old-fashioned Hardy Flowers are now exceedingly popular, and many of them are easily raised from seed. Our list bas again been largely increased this season, and is now the finest and most select offered in this country.

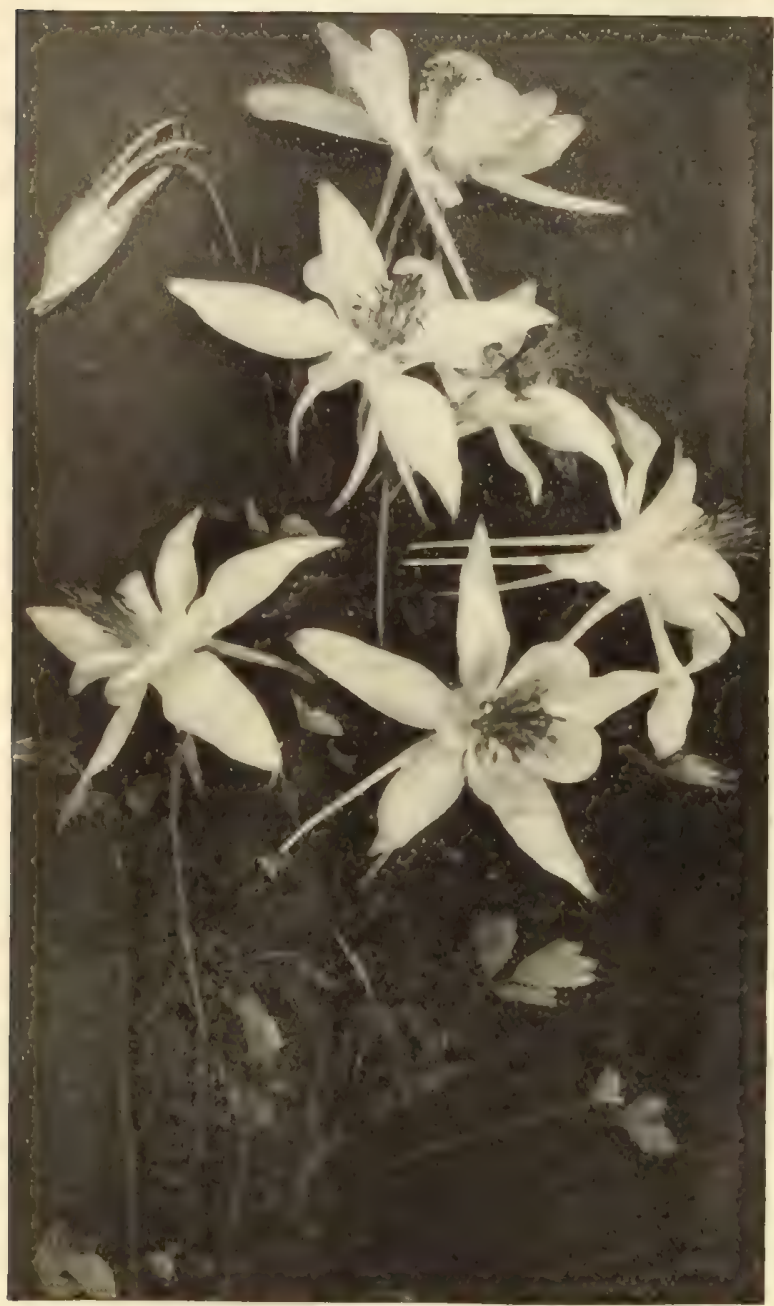

AQUILEGIA COLUMBINE

Acanthus molils latifolius

Achillea, Ptarmica f, Dl.. "The Pearl" (Double White Yarrow). A fine white cut flower; blooms all summer

Aconitum Napellus (Monkshood

Agrostemma Coronaria. Bright crimson

Alyssum Saxatlie Compactum, Yellow

Ampelopsls Veltch) (Boston Ivy). $\$ 1.50$ per Ib.

Anemone Coronaria. Mixed colors

St. Brigid. Semi-double, fine

Anthemis Tinctoria Kelwayl

Anchusa Italica Dropmore Variety

Aquilegia Californica Hybrida. Mixed colors

Canadensis. Red and yellow

Chrysantha. Yellow

Alba. Pure white

Coerulea. Blue and white

Hybrida. Mixed. Long spurred

Haylodgensis Delicatissima.

Flabellata nana alba. Dwarf white

Helena. Blue and white.

Nivea Grandiflora. Large white.

Veitch's Long Spurred Hybrids. Mixed colors

Single, mixed.

Double, mixed

Arabls Alpina. White spring flower

Armeria Formosa (Sea Pink or Thrift)

Asperuila Odorata (Sweet Woodruff)
Tr. pkt. Oz.

$10 \quad 20 \quad 15$ 300 $20 \quad 60$ $10 \quad 15$ 1030 $10 \quad 15$ $15 \quad 50$ 100 30 100 200 100 125
200 125 125 250 100 250 25 125 20 25 30 30 50

Aster. Perennial, mixed. (Michaelmas Daisies). Tr. okt. Oz.

Aloinus. Blue Albus: White

Auricula, Choicest mixed. (Primula)

Baptisia Australlis (False Indigo)

Bocconla Cordata (Plume Poppy)

Boltonia Asteroldes. White

Latisquama. Pink

Callirhoe Involucrata .

Campanula Carpatica. Blue.

Glomerats. Violet blue

Alba. White

Grandis. Deep blue.

Latlfolia macrantha. Large purplish-blue

Media calycanthems. Blue (CuD and Saucer.

$$
\text { \# } \quad \text { \# } \quad \text { Rose . Canterbury Bells) }
$$$$
\text { Single. Dark blue }
$$$$
\text { Single. Dark blue }
$$$$
\text { Light blue }
$$

$$
\because \quad \text { \# } \begin{aligned}
& \text { Rose } \\
& \because
\end{aligned}
$$

Mixed (Single Canterbury Bells) Double mixed (Canterbury Bells)

Imperialls

Persiclfolls grandinora Alba. White.

$$
\text { i. }
$$

$$
\text { Blue. }
$$

giganten Moerheimi. "Double" white.

Pyramidalls. Blue. (Chimney Bell Flower).. Alba. White

Trachelium

Cassia Marlandica

Cerastium Tomentosum (Snow in Summer)

Centaurea Montana. Blue.

$$
\text { Alba. White }
$$

Chrysanthemum Maximum "Triumph"

King Edward VII. The finest of the Moonpenny daisies

Shasta Daisy. Saved from a fine lot of mixed seedlings

Shasta Daisy. "Alaska." The finest of all the Shasta Daisies. Alaska." The finest of all the

Clematis Paniculata. (Japanese Virgin's Bower) $1 / 4-1$ b. $\$ 1.50$

Coreopsis Lanceolata Grandiflora. An extra fine strain of this useful golden yellow hardy perennial Cowslip Invinclble Olant. Mixed, a grand strain. Fine Mixed. All colors

Delphinium. We offer below a particularly fine list of these including some of the very choicest new hybrids. For full descriptions see pages 64 and 89 of our Garden Book or retail catalogue for 1913 .

Amos Perry. Rosy-mauve, flushed sky-blue Amyas Leigh. Sky-blue, white centre Belladonna. Light turquoise blue. Cashmerianum. Dark blue

Chinense. Various shades of blue. Album. White

Duke of Connaught. Oxford blue, white eye

Elatum. Dark blue, dark eye

Formosum. Fine blue. White eye Colestinum. Celestial blue

Julia. Cornflower blue, veined rose

Lizzie. Azure blue, yellow eye

Perfection, Rich blue, flushed rose, dark eye Portla. Cornflower blue, flushed rose

Oueen Wilhelmina. Soft lavender blue flushed rose, white eye

Rembrandt. Bright blue and rosy lavender

St. Paul. Rich blue, white eye..

Hybridum. Large flewering, double mixed

Gold Medal Hybrids. Very select strain. $1 / 4-1 b ., \$ 2.00$ Dianthus Plumarius (Pheasant Eye Pink). Single

- Double mixed

1. Double Dwarf Erfurt

Semperflorens (Double clove Pink)

Latifollus atrococcineus, f. pl. Bright fiery red double mixed
Tr. pkt. $0 x$. $40 \$ 200$ $30 \quad 150$ $50 \quad 300$ 50300 $10 \quad 30$ 1030 30. 150 
Digitalis Gloxiniaflora, Lilac

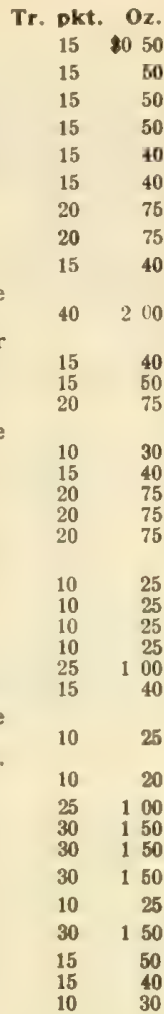

i. Mixed. All colors

Grandiflora. Light yellow

Maculata Superba. Fine spotted strain

Monstrosa (Mammoth Foxglove). Mixed

Echinops Ruthenicus.

Eryngium Amethystinum. A beautiful flower to use in dried bouquets

Eupatorium Fraseri. Fine white flowers useful for cutting

Ageratoides

Coelestinum

Galliardia Grandiflora superba. Mixed. One of the best perennials

compacta A dwarf variety

Kermesina splendens

Sulphurea oculata.

Geum Atrosanguineum, fl. pl.

Grasses, Ornamental. Erianthus ravenna (American Pampas)

\section{Eulalla Japonica Variegata}

Gynerium argenteum (Pampas Grass)

Pennisetum Japonicum (Hardy Fountain Grass)

Stipa Dennats.

Gydsophila Paniculata (Baby's Breath). The fine mist-like flowers are much used in bouquets

Paniculata fl. pl. Double flowering. $14 \mathrm{cts}$. per pkt. Acutifolla

Helenium autumnale superbum

Riverton Beauty

Riverton Gem

Helianthus Perennial varieties. Mixed

Hellodsis Pitcheriana (Orange Sunflower)

Heuchera Sanguinea (Alum Root)

Hibiscus Moscheutos

Crimson

Hollyhocks. We make a specialty of Hollyhocks, our stock is saved from perfectly healthy plants, carefully selected, and will be found to produce a very large percentage of the finest double flowers.

Double Bright Rose

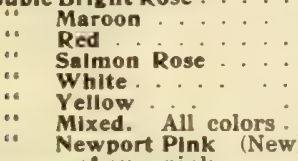

Newport Plnk

Allegheny. Fringed, mixed color

Single mixed

Iberis Gibraltarica hybrids.

Sempervireas

Irls Krempferi. Japanese Iris mixed

Lathyrus Latifollus Albus. White Pear

Plnk Beauty. Pink and white

Glant mixed (New).

Mixed. All colors

Lavandula vera. The true lavender

Liatris. Mixed

Linarla Cymbalaria (Kenilworth Ivy)

Macedonica Speciosa.

Llnum flavum. Yellow

Linum flavum.
Perenne. Blue

Perenne. Blue "tinest blue Flax

Lupinus poly ohyllus roseus

$$
\begin{aligned}
& \text {. } \quad \text { \# Blue } \\
& \begin{array}{ccc}
\because & \text { " } & \text { White } \\
\because & \text { Moerheimi }
\end{array}
\end{aligned}
$$$$
\text { i/ } 1 \text { ib., } 30 \text { ets. }
$$

Tr. pkt. $\mathrm{Oz}$

Lychnis Chalcedonica. Scarlet

10 cts. per pkt.

r. pkt. 0 z
20

hybrids. Various colors

Lythrum Roseum superbum (Rose Lobsestrife)

Enothera Perennial mixed

Pentstemon Barbatus Torreyil

Dicitalis

Ovatus

Pubescens

Fine Mixed

Phlox Decussata. The hardy perennial Phlox, saved from our own splendid collection. Finest mixed. 25 cts. per tr. pkt.; $\$ 1.00$ per oz.

Phy sostegla Virginica. Pink

Tr. pkt.

Platycodon Japonicus, $\mathrm{fl}$

Mariesi. Dwarf blue.

Orandiflora. Blue.

Alba. White

Polemonium Richardsoni. Blue

Album. Whit

Polyanthus Gold-laced . . Album. White

Invincible Giant. Very large and fine. . . .

Finest Mixed
$15 \quad 2050$

$15 \quad 50$

30150

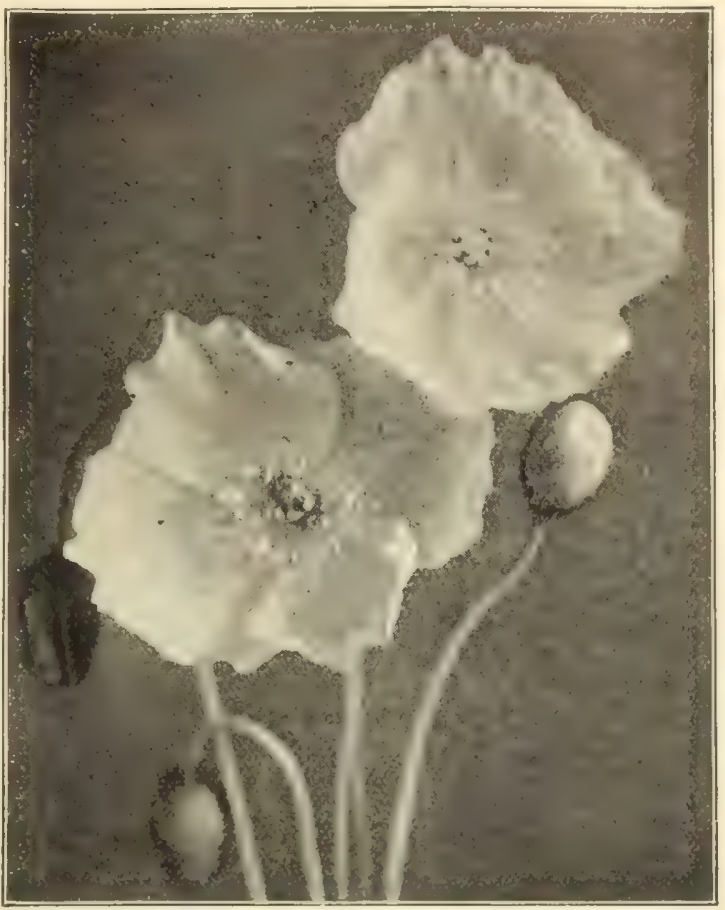

Papaver nudicaule (Iceland Poppies).

Tr. pkt. Oz.

Poppy Bracteatum (Papaver)

Nudicaule (Iceland Poppy)

$\because \quad$ Bright Yellow

Orange Scarlet Pure White.

$\because \quad$ Mixed

“. New Hybrids

Orientale. (Oriental Poppy.) Deep crimson

Mammoth. Glowing scarlet.

i. Princess Victorla Loulse. Salmon pink Psyche. Rosy blush Hriby. Brilliant

Primula Japonica (Japan Primrose)

Vulgaris (English Yellow Primrose)

Veris (Cowslip). Mixed

Elatior (Polyanthus) Mixed

Pueraria Thunbergiana. (Kudzu Vine)

Pyrethrum Hybridum, single. Mixed colors grandiflorum. Single large flowering

Double. Saved from a fine Uilginosum. (Giant Daisy)

Rehmannia Angulata.

Rosmarinus Officinalis (Rosemary)

Rudbeckia Newmanni

Fulgida

Purpurea (Giant Purple Cone-flower

Salvia Azurea Grandiflora

Farinacea. Light blue

Scabiosa Caucasica. Pale lavender

Japonica

Solidago Canadensis. (Golden Rod)

Statice. Mixed varieties

Stokesia Cyanea (Corn-flower Aster). A beautiful

lavender blue, hardy perennial, flowering the first

year from seed if sown early

Cyanea alba. Pure white

Sweet Rocket (Hesperis.) Mixed

Sweet Willam, Single White

Single Crimson

-. Scarlet

i. Velvety Black Maroon

: Red, on white ground

Vlolet, on white ground

$\because \quad$ Mixed. All colors. $1 / 6$ lb., 50 cts.

* Holborn Glory. Auricula flowered

i. Newport Plnk (new)

Double Mixed. All colors. $i / 4$ lb. 1.50 Giant mixed. Very large

Thallctrum Aquilegiafolium

Tritoma Hybrida. Mixed varieties. (Red-hot Poker).

Vunica saxifraga

Valeriana mixed (Valerian)
Veronica splcata.
$10 \quad 8025$

$15 \quad 50$

50

100

50

250

250

200

100

100

150

15

50

I 25

2 D0

100

200

25

100

50
75

200

50

150

100

30

25

75

100

15

30

30
30

30

30 


\section{SUMMER FLOWERING BULBS}

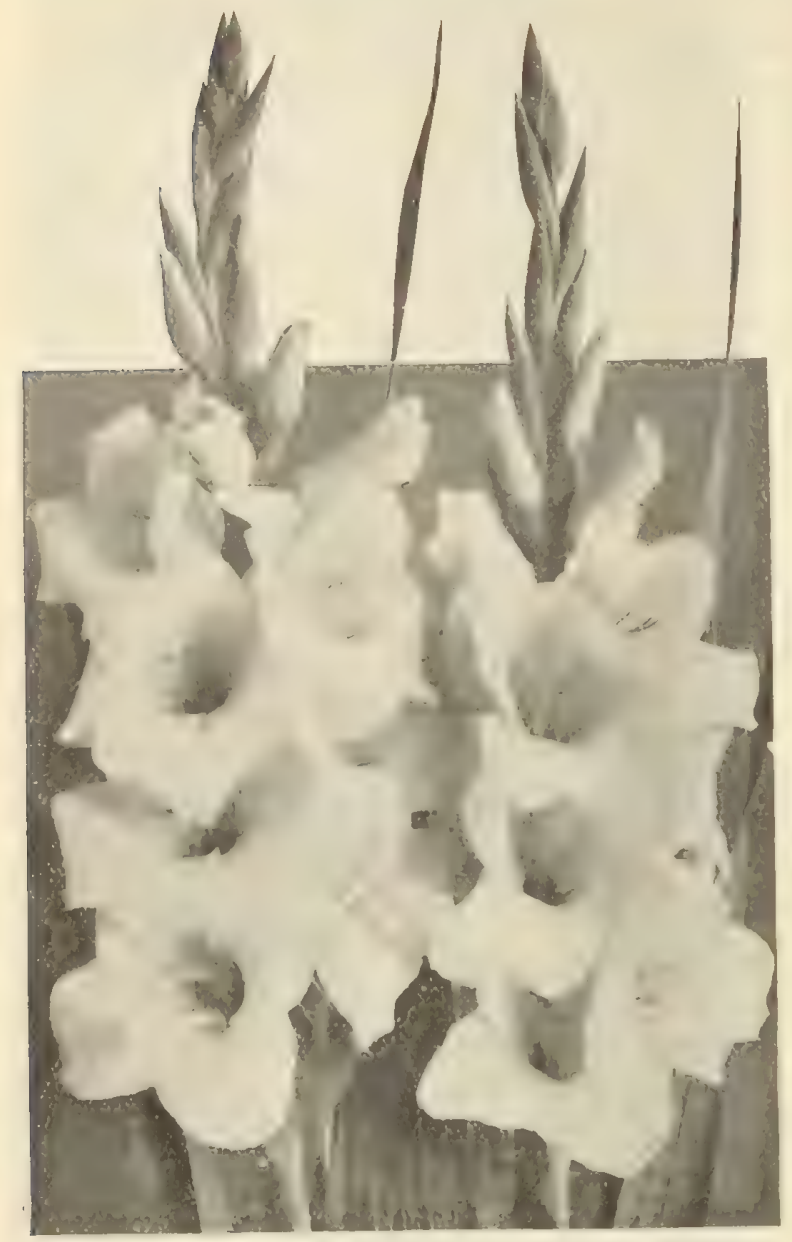

GLADIOLUS AMERICA

Amaryllis.

Burbank's Hybrds. We have secured from Mr. Luther Burbank stock of his magnificent hybrids. All large bulbs that will give immediate results . Aulica Platypetala

Formosissima

Johnsonil

Prince of Orange

R. H. James, Dazzling scarlet, feathered with white 75 Solandriflora conspicua .......... 50

Vittata Hybrids.

Wullamsi

Amorphophallus.

Rivierl, Strong bulbs

Tuberous-rooted Begonias.

We handle the very finest strain that money can buy, being grown for us by a noted specialist.

Single. Scarlet, white, crimson, rose, yellow Doz. 1001000 and orange

Single. All colors mixed

(1)

Double. Scarlet, rose, white and yellow ... $60 \quad 450$

Double. All colors mixed ......... $50 \quad 400$

Zepoelin. Double scarlet . 100700

Lafayette. Brilliant crimson scarlet.... I $50 \quad 1000$

Frau Helene Harms. Primrose yellow .... 200

Single Frilled. Carmine, scarlet, orange, sal-
mon, white, pink and blush.

mon, white, pink and blush .
Double Fringed. White, rose and scarlet... $150 \quad 1000$

Caladium Esculentum (Elephant's Ear).

Large Bulbs, 9 to 11 inches in cir.

First Size, 7 to 9 inches in cir.

Second Size 5 to 7 inches in cir.

Doz. 1001000

$75 \quad 8550 \quad 85000$

$50 \quad 350 \quad 3000$

$30 \quad 200 \quad 1500$

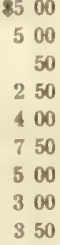

900
Fancy-leaved Caladiums.

We offer selections as follows:

Choice Standard Named Varieties

Choice Rare and New Varieties

Doz. $100 \quad 1000$

$\$ 175 \$ 1200 \$ 100 \quad 00$

$\begin{array}{rlllll}2 & 25 & 15 & 00 & 140 & 00\end{array}$

Choice Mixed Varieties. . . " " . $150 \quad 1000$

Calla Lilies. Each Doz. 100 Golden Yellow (Richardia Elliottiana) $\therefore \cdots \cdots 20 \quad 8200 \$ 1500$ Spotted-leaved (Richardia Alba Maculata).: : $\quad \begin{array}{rr}60 & 400\end{array}$

Strong Roots

\section{Cinnamon Vine.}

$40 \quad 800$

Dahlias (See pages 23 to 27 ).

Eucomis Punctata (Pineapple Flower).

Strong bulbs, 15 cents each; $\$ 1.50$ per dozen.

\section{New and Extra Choice Gladiolus}

America, The finest for cutting. Color, a beautiful soft flesh pink. 50 cts. per dozen; $\$ 3.00$ per $100 ; \$ 25.00$ per 1000

Blanche. The finest white of the Giant type, immense flowers of pure white, lightly marked with pale rose, splendid for cutting. 85 cts. per dozen; $\$ 6.00$ per 100.

Cardinal. The most brilliant cardinal-scarlet yet introduced; large flowers in fine spikes, $\$ 1.00$ per dozen; $\$ 6.50$ per 100 .

Charlemagne. Rich rosy red shaded darker, large creamy white blotches dotted with purple carmine. Extra fine. $\$ 1.50$ per doz.: $\$ 10.00$ per 100 .

Deull de Carnot. Superb, large open flowers of velvety crimson maroon, the richest colored of all. $\$ 1.50$ per dozen; $\$ 12.00$ per 100 .

Eucharls. Large flowers on long spikes. Color, delicate blush white blotched, slightly deeper. $\$ 1.00$ per dozen; $\$ 8.00$ per 100 .

Europa. The finest pure white yet introduced, massive spikes of very large flowers of purest white. 60 cts. each; $\$ 6.00$ per dozen. General Langlois. Rich cherry-rose or fuchsia color, suffused with deep rosy red and light cream markings in the lower petals; very large open flowers. 85 cts. per dozen; 86.00 per 100.

Hellotrope Velvety bishop's violet, shaded with pansy-purple, rich and novel. $\$ 1.50$ per dozen;:\$10.00 per 100 .

Princeps. Immense, wide-open flowers, almost 6 inches across, of a rich, dazzling scarlet, marked with white in the lower portion, which serves to intensify the brilliancy of the scarlet. $75 \mathrm{cts}$. per dozen; 8.00 per $100 ; 48.00$ per 1000 .

Sulphur King. The finest clear yellow yet introduced. $\$ 1.50$ per dozen; 12.00 per 100 .

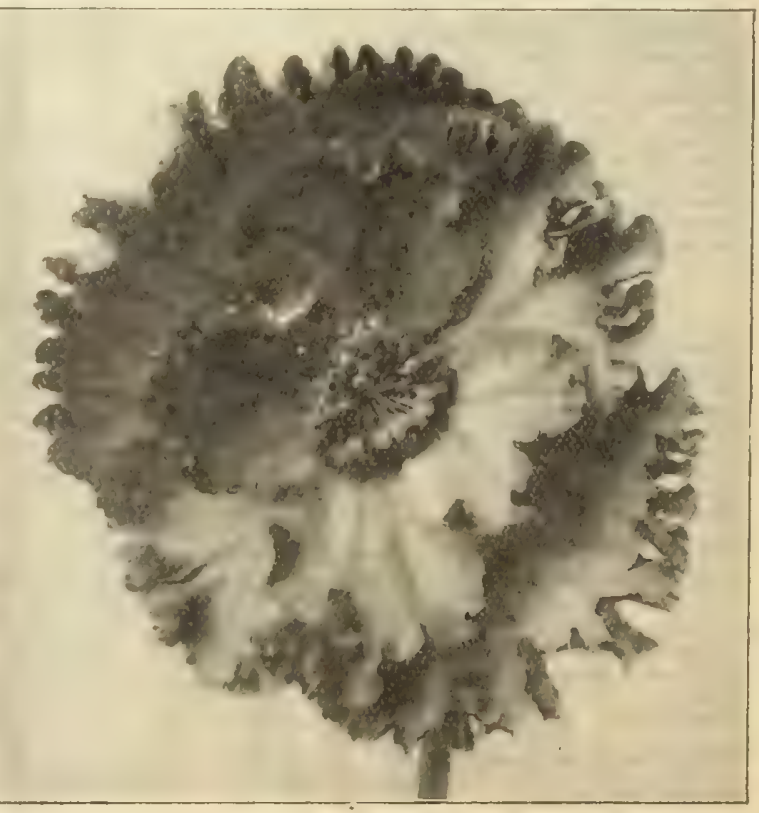

FRILLED TUBEROUS BEGONIA 


\section{Fine Named Gladiolus.}

While we do not handle a long list of named Gladiolus, the varieties listed below are a selection of the best and most distinct kinds for florists' use. See also the Extra Choice sorts offered on opposite page.

All selected first-size bulbs, We do not handle "seconds."

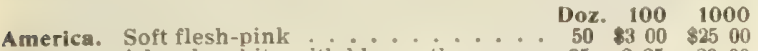

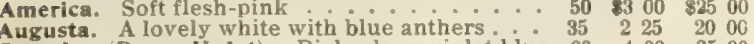

Blue Jay (Baron Hulot). Rich, deep violet blue $\begin{array}{llll}60 & 400 & 3500\end{array}$

Brenchleyensis. Vermilion scarlet. $\quad \cdots \quad \begin{array}{llll}25 & 150 & 1200\end{array}$

Brilliant. Glistening scarlet, white throat. : : $\begin{array}{llll}50 & 3 & 50 & 3000\end{array}$

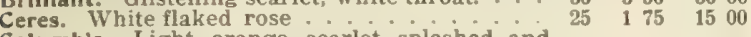

Columbia. Light orange scarlet splashed and $\begin{array}{llll} & & & \\ & & \end{array}$

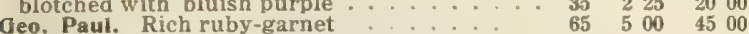

Oil Blas. Salmony rose blotched red on straw-

colored ground $\ldots . .60 \quad 450 \quad 4000$

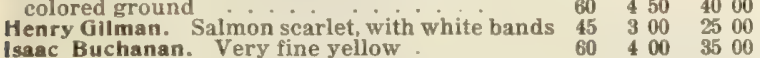

Jessle. A fine early flowering velvety red. Very

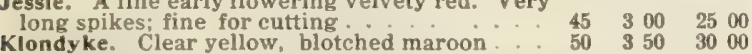

La Candeur. Of special value owing to its being

the latest of all to flower; color, creamy white

$\begin{array}{ccc}\text { and rosy markings, spikes } 4 \text { to } 5 \text { feet long.: } & 85 & 650 \\ \text { May. White ground, penciled rosy crimson : } & 30 & 200\end{array}$

Mrs. Frances King. A striking shade of light $30 \quad 2 \quad 00 \quad 1800$

scarlet or flame color, a very effective cut

flower variety ................................

Rosella. Delicate rose stained, purple and white 7

Shakespeare. White suffused and flaked rose

Scribe. The Giant flowering Eugene Scribe, a

fine light colored variety for cutting. . . . .

wm. Falconer. A grand pink sort .

\section{0 \\ $5 \begin{array}{lll}50 & 50 & 00\end{array}$}

$600 \quad 5000$

$500 \quad 4500$

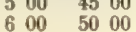

\section{Gladiolus. Mixed Varieties.}

We exercise great care in the making of our mixtures; they are not merely surplus lots thrown together, but a careful blending of good sorts which cannot fail to give full satisfaction.

All selected first-class bulbs. We do not handle "seconds."

Scarlet and Crimson, mixed

White and Light, shades mixed

Yellow and Orange, shades mixed.

Striped and Variegated, mixed.

Pink and Rose, shades mixed.

Pink and Rose, shades mixed

New Glant (Childsii), mixed.

Lemoine's Hybrids, mixed .
Groff's Hybrids, extra fine mixed

mixed ........ 2

fine mixture, deneral Mixture. A really very

light colors

Dox. $100 \quad 1000$

$25 \$ 150 \$ 1300$

$\begin{array}{llllll}30 & 1 & 75 & 15 & 00\end{array}$

$\begin{array}{lllll}55 & 4 & 00 & 35 & 00\end{array}$

$25 \quad 175 \quad 1500$

$30 \quad 200 \quad 1750$

$251150 \quad 1400$

1501300

$20 \quad 100 \quad 900$

\section{Groff's Gold Medal Gladiolus.}

We offer these in three sections, also in a general mixture of all the sections. For those who want an extra fine mixture, these cannot be surpassed.

Doz. $100 \quad 1000$

Section 1. All the rich red shades ...... $40 \quad \$ 275 \$ 2500$

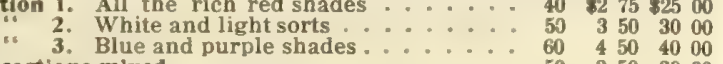

All sections mixed.

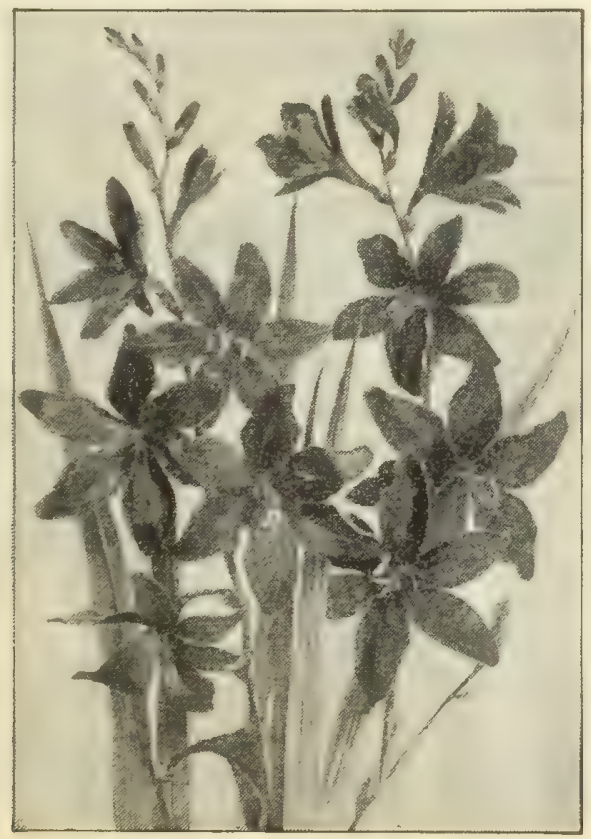

MONTBRETIA GERMANIA

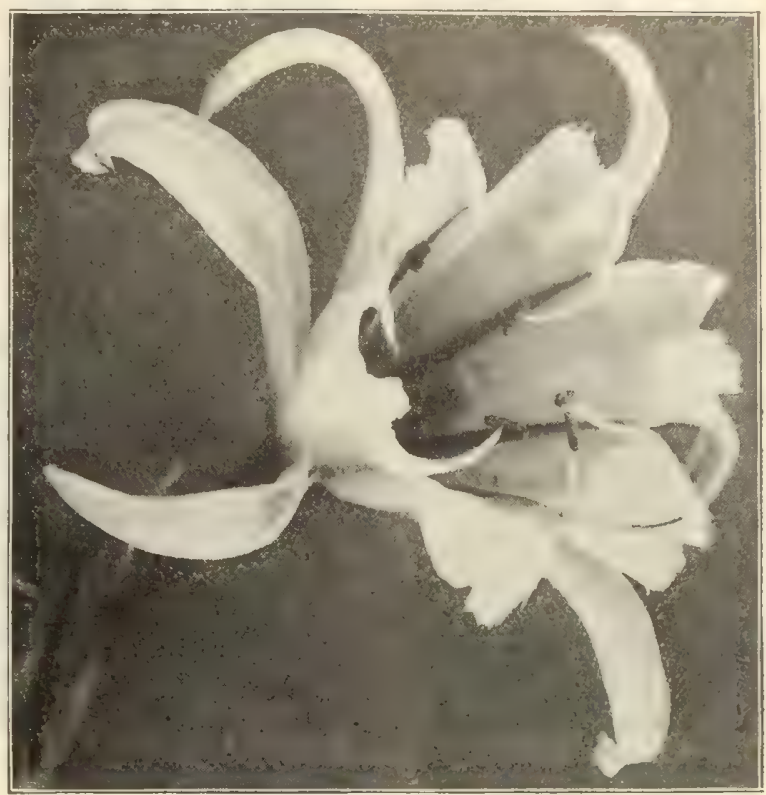

ISMENE CALATHINA

Dreer's Superb Gloxinias.

Mixed or separate colors

Doz. 1001000

New Emperor. Mixed colors

$30 \quad 60 \quad \$ 350 \$ 3000$

\section{Hyacinthus.}

Per doz. Per 100 Candicans (Cape Hyacinth) .......... \$0 $30 \$ 200$

\section{Ismene.}

Calathina. A beautiful summer flowering bulb. producing large pure white Amaryllis-like flow ers, useful for cutting. Strong flowering bulbs

\section{Liliums.}

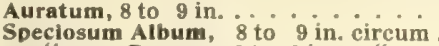
Roseum, 8 to 9 in.
Rosiosum.

Roseum, 8 to 9 in.
Magnificum, 8 to 9 in.

Tigrinum Splendens. Fine bulbs

$\begin{array}{rrr}85 & 600 \\ 125 & 800 \\ 80 & 550 \\ 80 & 550 \\ 60 & 400\end{array}$

\section{Madeira Vine.}

Strong roots ...

Milla.

Biflora.

All of these are highly useful to the florist as a late summer cut flower, particularly the new large flowering variety Germania.

Per doz. Per 100

Aurantiaca

$25 \$ 150$

Crocosmiaflora

Etoile de Feu.

Germania.

Rayon d'or

Rheingold. New. Flowers 2 inches and over in

diameter, very freely produced on 2 feet high

diameter, very freely produced on 2 feet high
branching stems, color rich glowing yellow, re-

Speciosa.

Tigridias.

Conchiflora

$15 \quad 100$

25150

$25 \quad 150$

150

501000

Grandiflora Alba.

Pavonia Grandiflor.

Doz. $100 \quad 1000$

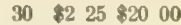

$\begin{array}{lllll}30 & 2 & 25 & 20 & 00\end{array}$

$\begin{array}{lllll}30 & 2 & 25 & 20 & 00\end{array}$

Tuberoses.

Double Excelsior Pearl, extra selected bulbs, 4 to

6 inches.

$20100 \quad 900$

Vallota.

Purpurea, strong bulbs

Per doz. Per 100 $\$ 200 \$ 1600$

Zephyranthes. 


\section{Water Lilies and Aquatics}

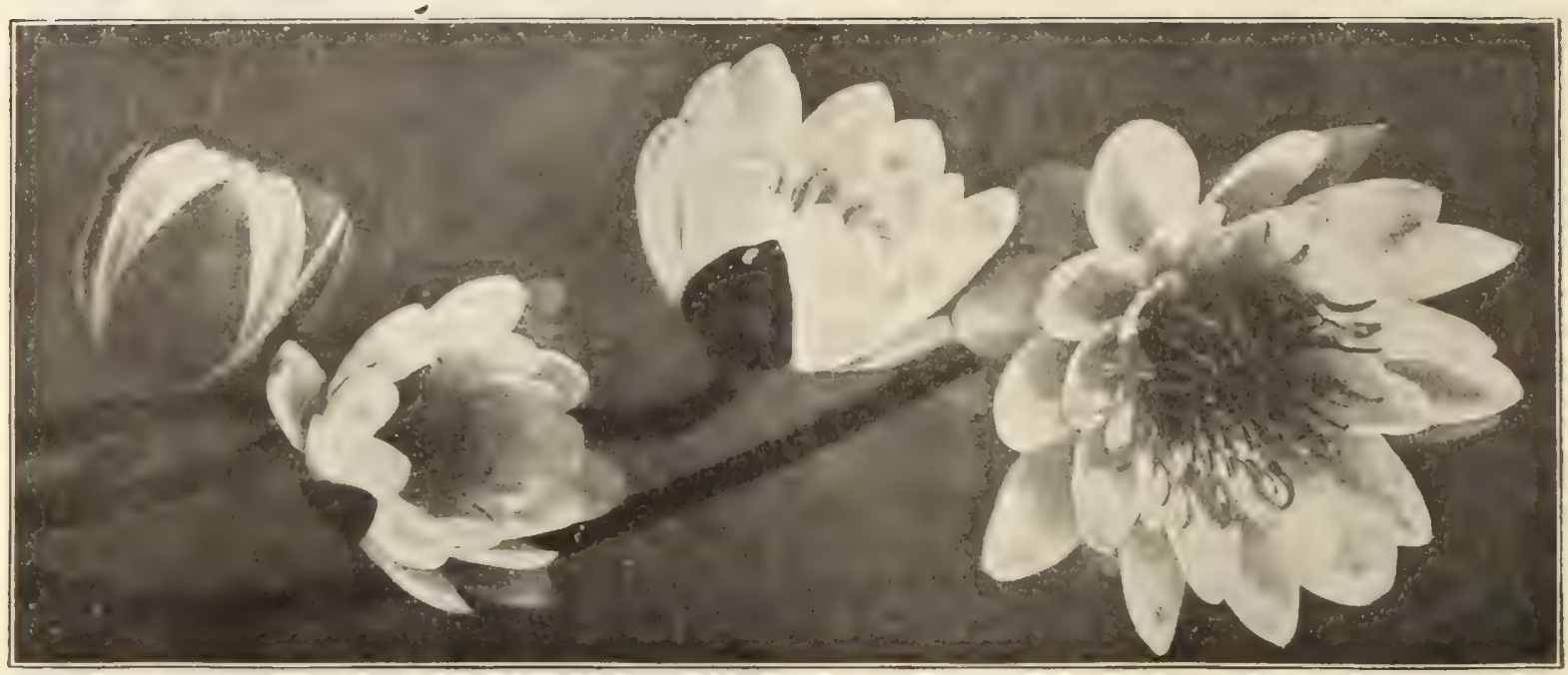

(Nymphieas ready April 1st' Nelumbiums ready May Ist.)

New and Rare Hardy Nymphras.

Aurora. Soft rosy yellow

Fulva. Orange red

Gloriosa. Dark red

Helen Fowler. Soft pink

James Brydon. Rich rosy crimson

James Brydon. Rich rosy

Marilacen Rosy vermilion

Marllacea Rubra Punctata. Rosy purple

Marliacea Rubra Punctata. Rosy pu

William Faiconer. Brilliant dark red

W. B. Shaw. Bright rosy flesh

\section{General Collection of Hardy Nymphæas.}

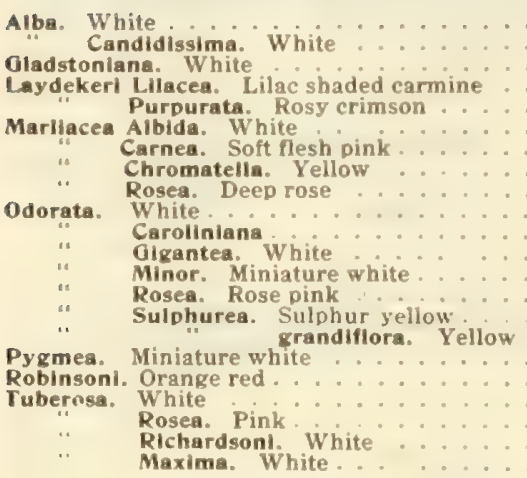

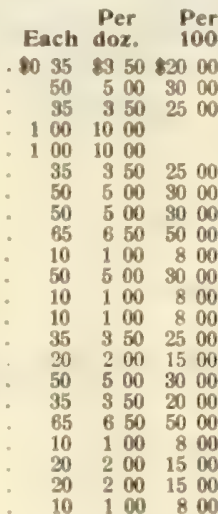

\section{Nelumbiums.}

Pot-grown plants of any of the following can be supplied after June 1 st at an advance of $\$ 1.00$ per plant on the prices below.

Speciosum. Extra strong roots

Each Per doz. Album Grandiflorum. Pure white Strlatur... 150 Kermesinum. Soft rose Kinshiren. White shaded rose

Luteum. Yellow

Osiris. Rosy carmine

Roseum. Rose pink

$$
\text { plenum. Double rose pink }
$$

Shiroman. Double white

Pekinensis rubrum. Brilliant rosy carmine

plenum. Double deep rose
Each

2050

200

50

125

Mrs. C. W. Ward. Rosy pink
O'Marana. Pink, shaded crimson
Pennsylvania. Blue

Pennsylvania. Blue

Pulcherrima. Light blue

Rubra. Purplish red

Rosea. Rosy carmine

Sturtevanti. Pink, shading to red

Wm. Stone. Rich violet-blue

Zanzibariensis. Deep blue

$$
\text { Azurea. Light blue }
$$

Miscellaneous Aquatics.

Acorus Japonica variegata

Acorus Japonica variegata... Best aquarium

Aponogeton Distachyon

Crassipes Major Water Hyácinth

Jusslæa longifolia

Limnanthemum Indicum

Limnocharis Humboldti (Water Poppy) Plumieri

Ludwigia Mulerttil

Myrlophyllum Proseroinacoldes (Parrot's Feather)

\section{Orontium aguaticum}

Ouvirandra Fenestralls

Papyrus Antiquorum

Peltandra Virginico

Pistia stratiotes (Water Lettuce

Pontederia cordata

Ranunculus lingua grandiflora. (Giant Aquatic

Buttercup

Sagittaria Montevidiensis

Saururus cernuus

Scirpus Tabernamontana Zebring

Trapa natans

Zizania aquatica (Wild Rice)

Water Lily Seeds.

Nymphaea Zanzlbariensis, purple azures, blue

$$
\text { " } \text { " Tender Varieties, mixed. }
$$

Victoria Regla. $\$ 2.00$ per doz seeds. Trickerl. \$2.00 per doz. seeds.
Each Per doz. $\$ 175 \$ 2000$ $\begin{array}{rr}50 & 500 \\ 50 & 500 \\ 100 & 1000\end{array}$ $50 \quad 500$ $50-500$

Tr. pkt. $\mathrm{Oz}$ $25 \quad 8200$ $\begin{array}{lr}25 & 150 \\ 25 & 150 \\ 25 & 150 \\ 25 & 100\end{array}$ 


\section{Garden, Greenhouse and Decorative Plants}

For Condensed List of Miscellaneous Varieties see page 35

Our stock of this class of plants is of the usual high quality with which the trade is familiar

\section{Ananas Sativa Variegata.}

Variegated Pineapple.

Of this most beautiful of all variegated plantsiwe nowiare inlposition to offer at less than one-tenth the price at which they were sold three years since. You will make no mistake in making a trial of these, it will give you a variation in your foliage plants which is certain to be appreciated by your customers.

Good 4-inch pots, $60 \mathrm{cts}$. each.

Fine 5 -inch pots, $\$ 1.00$ each.

\section{Anthuriums.}

Andreanum Hybrids. A fine collection of seedlings, from which we can select the following colors, in large-sized flowers: White, red and rose. 75 cts. and $\$ 1.00$ each.

Scherzerianum. Brilliant scarlet flowers. $50 \mathrm{cts}$. each.

Majus. Large crimson scarlet. $\$ 1.00$ each.

Mme. Dalliere. Soft salmon. $75 \mathrm{cts}$. each.

Rothschildianum. Creamy-white, spotted crimson. \$1.00 each.

Sanguineum. Rich crimson. $\$ 1.00$ each.

Majus. Very large rich crimson flowers. $\$ 1.50$ each.

Magnificum. Olive-green foliage, with silvery veins. 50 and 75 cts. each.

Regale. Large foliage tinted rose when first unfolding, changing to a dark metallic green. 50 and 75 ets. each.

Araucaria Excelsa (Norfolk Island Pine).

New Imports Ready May loth.

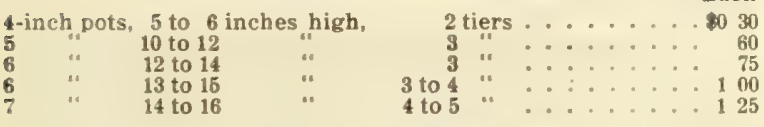

\section{Araucaria Excelsa Glauca.}

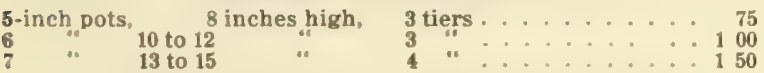

\section{Araucaria Excelsa Plumosa.}

A splendid variety, almost as compact as Robusta Compacta, and of a richer, deeper color.

$\begin{array}{lll}5 \text {-inch pots, } 10 & \text { inches bigh. } \\ 6 & 12\end{array}$

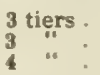

\section{Araucaria Robusta Compacta}

5 -inch pots, 8 to 10 inches high, 2 tiers..... . . 8075

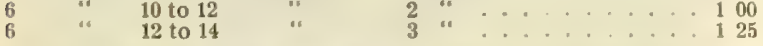

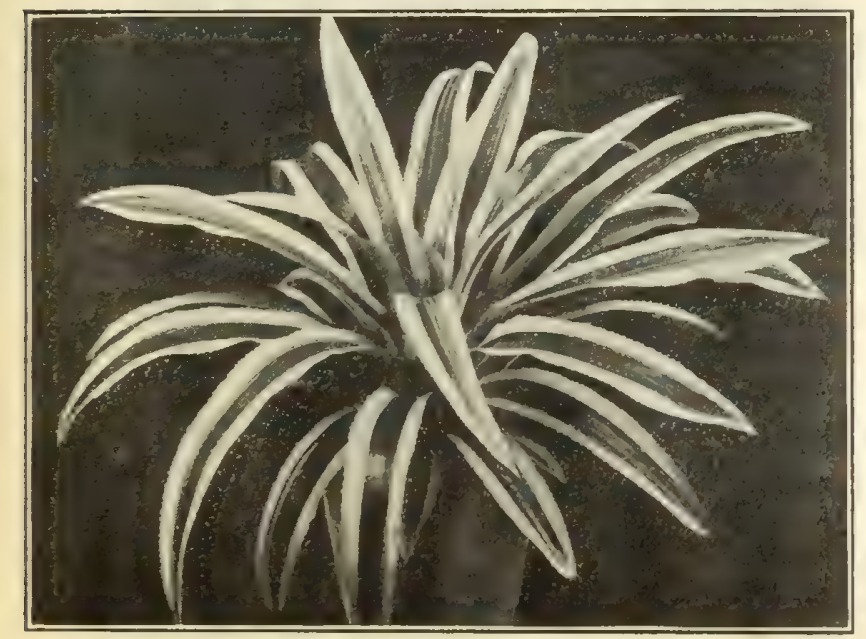

ANanas (Variegated Pineapple)

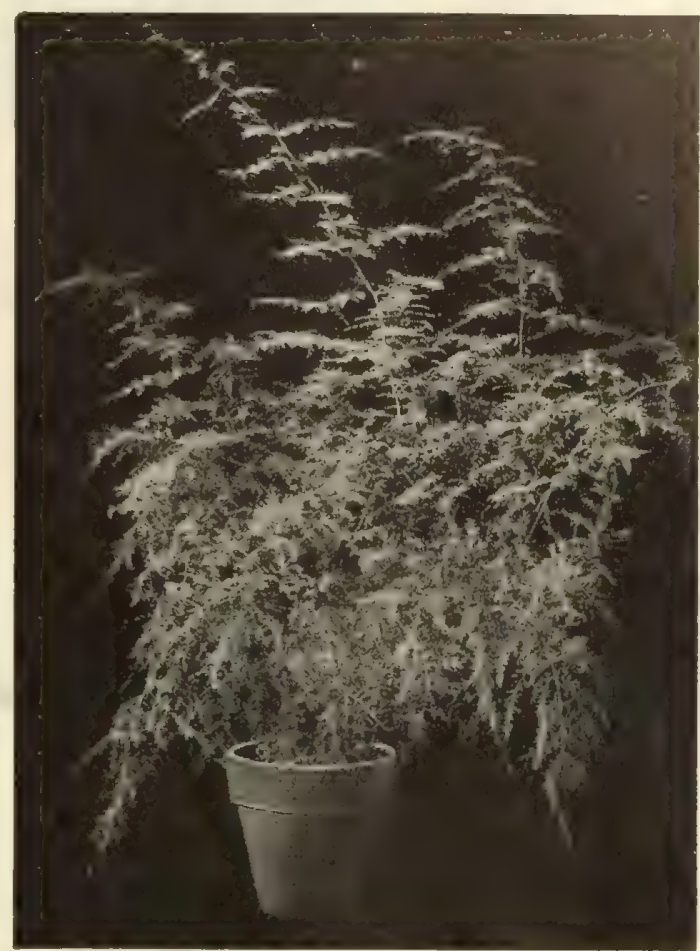

ASPARAGUS PLUMOSUS HATCHERI

Asparagus Plumosus Hatcheri.

It would hardly be possible to praise this new type too much, and it has already made a name for itself among the most critical growers. It is of very rapid growth, the fronds set closer on the stems than the very best type of Plumosus Nanus, making a fuller, heavier string and when cut lasts longer in good condition than any other and is just as good for bunching as the old sort. We will not be surprised if it quickly becomes the leading variety.

$2 \%$-inch pots, $\$ 1.00$ per doz.; $\$ 6.00$ per $100 ; \$ 50.00$ per 1000 .

New Crop Seed of the above, $\$ 1.00$ per 100 seeds; $\$ 7.50$ per 1000 seeds.

\section{Asparagus Plumosus Nanus.}

$2 \frac{1}{4}$-inch pots

Per doz. Per 100

3

New Crop Seed of the above, 50 cts. per 100 seeds; $\$ 4.00$

$60 \$ \$ 00$

per 1000 seeds.

Asparagus Sprengeri.

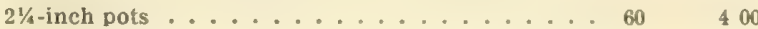

3 . . . . . . . . . . . . . 75

New Crop Seed of the above 25 cts. per 250 seeds; 75 cts. per 1000 seeds; 83.00 per 5000 seeds.

\section{Aspidistra.}

Each

Lurida. Green-leaved, 4-inch pots, 6 to 7 leaves.

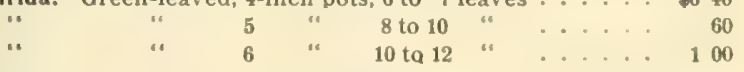

Aucuba Japonica.

12 inches high

Each. Doz.

18 to 20 inches high

\$0 $35 \quad \$ 350$

24 inches high

500

$2^{1 / 2}$ to 3 feet high 


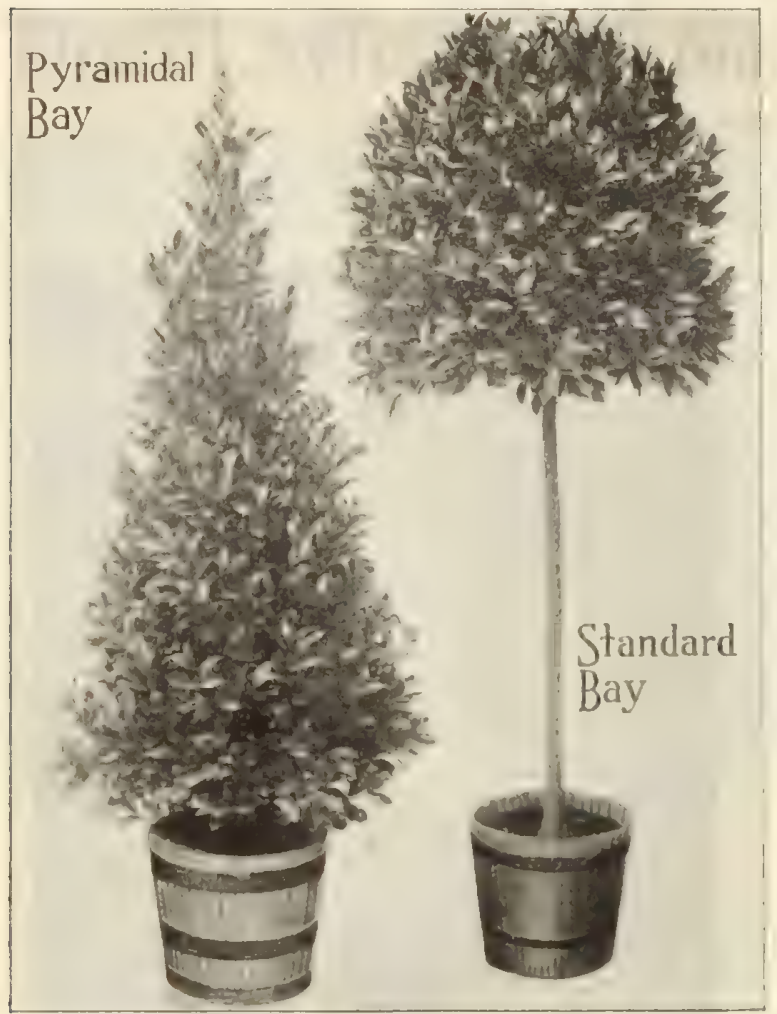

Bay Trees (Laurus Nobilis).

An exceptionally fine lot of clean, dark-colored trees of unusual good values.

Standard or Tree-Shaped.

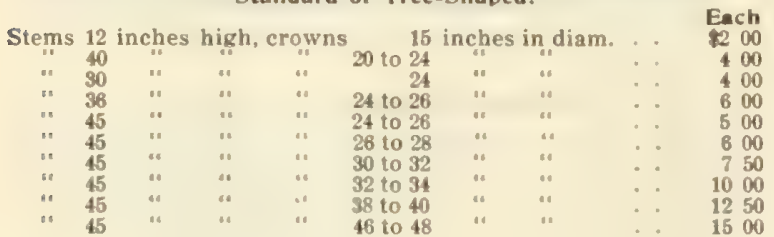

Py ramid-Shaped

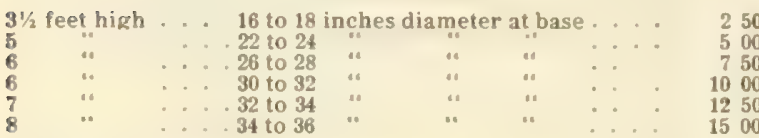

\section{Boxwoods.}

\section{Bush-shaped Box.}

A nice line of bushy plants, the smaller sizes being especially useful for the filling of window boxes and similar decorative work.

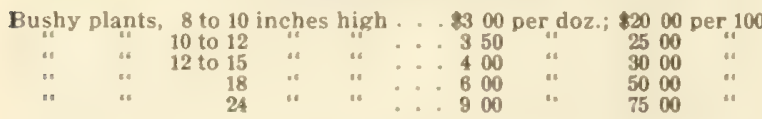

Pyramid-Shaped Boxwoods.

These are all shapely plants and are supplied in green-painted tubs.

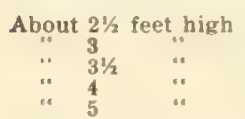

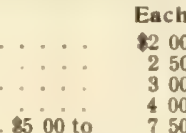

Boxwood Edging.

Splendid bushy stock, 4 to $5 \mathrm{in}$. high, $\$ 5.00$ per $100 ; \$ 5.00$ per 1000

\section{Dreer's Extra Select Tuberous=Rocted Begonias}

Through careful selection, every season sees an advance in the quality of these beautiful: Begonias. Our stock is grown for us by one of the most eminent specialists in Belgium, whose strain is celebrated for its size, rich coloring, form and substance.

The price is as low as is consistent with good quality. The retail florist who is growing a few hundred bulbs for his spring trade will find many of the cheap strains of fered dear at any price. We offer but one quality, and that is the best.

Single Varieties in Colors. Scarlet, crimson, white, rose, yellow and orange. $40 \mathrm{cts}$, per doz.; $\$ 2.50$ per $100 ; \$ 22.50$ per 1000 .

Single Varieties in Choice Mixture. 35 cts. per doz.; $\$ 2.25$ per 100 $\$ 20.00$ per 1000

Double Varieties in Colors. Scarlet, rose, white and yellow. $60 \mathrm{cts}$. per doz.; 4.50 per 100: $\$ 40.00$ per 1000 .

Double Varieties in Choice Mixture, 50 cts. per doz.; 8 . 00 per 100 $\$ 35.00$ per 1000

\section{Dwarf Hybrid Tuberous Begonias.}

These are of dwarf habit, and throw up numberless stems of full double flowers from early in July until cut down by frost. Zeppelin. Pure rich scarlet. $\$ 1.00$ per doz,; $\$ 2.00$ per 100 . Lafayette. Brilliant crimson-scarlet $\$ 1.50$ per doz: $\$ 10.00$ per 100 . Frau Helene Harms. A new primrose-yellow variety. 20 cts. each; $\$ 2.00$ per doz.

\section{Single Frilled Tuberous-Rooted Begonias.}

Very large single flowers, the petals wavy and beautifully frilled. Similar to the newer forms of Petunias. Strong bulbs in scarlet. white, pink and yellow. $85 \mathrm{cts}$. per doz.: $\$ 6.00$ per 100.

\section{Double-fringed Tuberous Begonias.}

The individual flowers of large size, full double form and brilliant color, the edges of the petals deeply cut or serrated, adding a most desirable character of lightness to the flower. We offer three distinct colors - white, rose and scarlet. $\$ 1.50$ per doz.; $\$ 10.00$ per 100

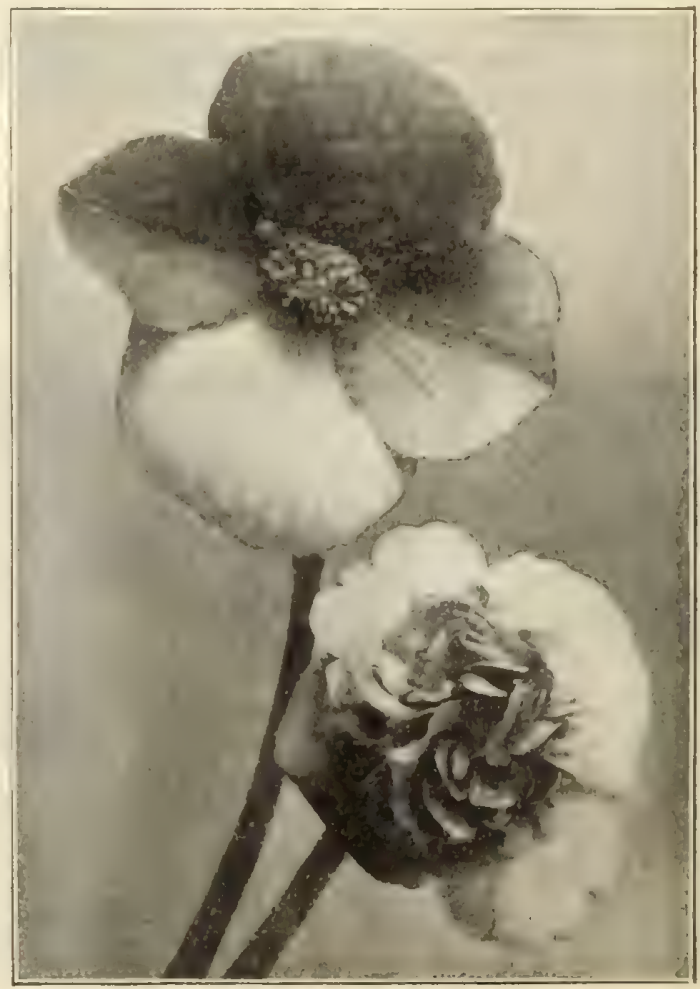

SINGLE AND DOUBLE TUBEROUS BEGONIAS 


\section{Fancy=leaved Caladiums.}

We have an immense stock of these including the finest of the old standard varieties, the choicest Brazilian introductions as well as a number of extra fine new varieties. No other plant is so valuable for the decoration of the florist's store window during the summer months, and during recent years we have sold many thousands for this purpose. The bulbs this season are exceptionally large and fine.

We offer special selections according to variety, as follows:

Choice Standard Varieties. The finest collection ever offered at

the price. 81.75 per doz.; $\$ 12.00$ per $100 ; \$ 100.00$ per 1000 .

Choice Rare and New Varieties. $\$ 2.25$ per dozen; $\$ 15.00$ per 100 $\$ 140.00$ per 1000

Rare New Varieties. $\$ 3.50$ per dozen: $\$ 25.00$ per 100

Cholce Mixed Varieties. $\$ 1.50$ per doz.; $\$ 10.00$ per 100

\section{Callas (Richardia)}

Elliottiana. This is the best of the yellow-flowering varieties. Strong bulbs, $\$ 2.00$ per dozen; $\$ 15.00$ per 100 .

Spotted-leaved (Richardia Alba Maculata). 60 cents per dozen: 84.00 per 100.

\section{Camellia Japonica.}

We are pleased to see these old favorites again coming into favor and in view of this we have prepared a splendid stock of the most popular varieties in thrifty, bushy, well branched plants.

5 -inch pots, 15 to 18 inches high. $\ldots$ Each Per doz. Per 100
20 to 24

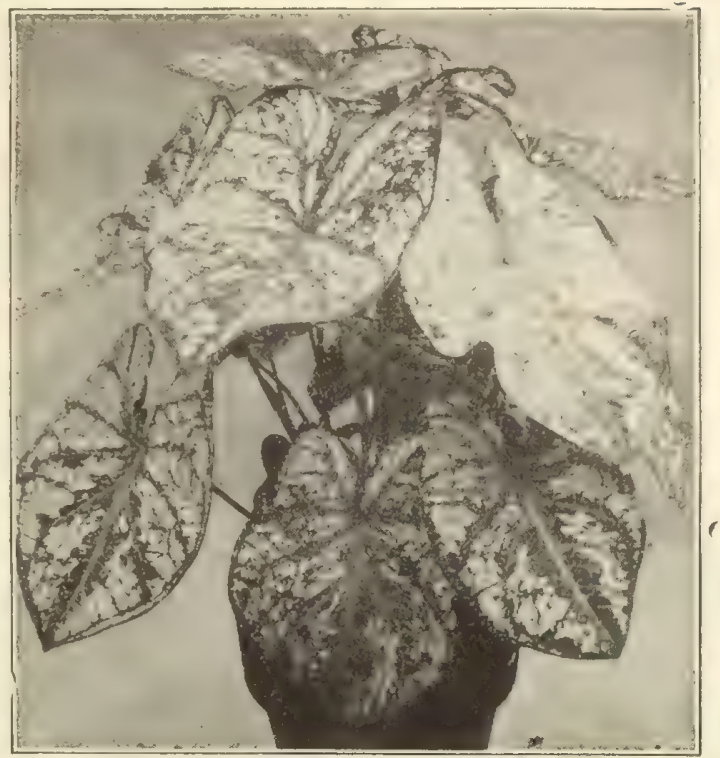

FANCY-1.EAVED CALATIUMS

\section{LARGE-FLOWERING CANNAS}

\section{Recent Introductions and Varieties of Special Merit}

Where not otherwise specified the foliage is green.

Ami Gulllaud. The flowers are large and quite distinct from others of this type, a bright yellow freely spotted with rosy-carmine $31 / 2$ to 4 feet. 25 cts. each: $\$ 2.50$ per doz.

Dr. E. Ackernecht. Carmine-lake suffused with deep carmine, a distinct new shade, foliage bronze; 4 feet. 35 cts. each; $\$ 3.50$ per doz.

Eldorado. A strong, robust variety with immense yellow flowers which are veined with red, an unusual color distribution; 4 feet. 20 cts, each: $\$ 200$ per doz.

Garam. Large, bright carmine-red flowers, freely produced on vigorous growing plants, very distinct; $31 / 2$ to 4 feet. $35 \mathrm{cts}$. each \$.50 per doz.

Gladioflora. Remarkable on account of the unusual shape of its flowers, which look like a large Gladiolus; color crimson, changing to carmine-rose, with an irregular edge of gold: $3 \frac{1 / 2}{2}$ feet. 15 cts. each; $\$ 1.50$ per doz.; 10.00 per 100 .

Gustav Gumpper. This is the ideal rich yellow bedding Canna, the flowers of good size are held well above the foliage, the fine trusses are always clean looking, and very uniform in habit of growth; $3 \frac{1 / 2}{2}$ to 4 feet. 35 cts, each; $\$ 3.50$ per doz; $\$ 25.00$ per 100

Hungaria. The ideal pink bedder, flowers very large, in good trusses, color not unlike that of the Paul Neyron Rose; 3 to $3^{1 / 2}$ feet. $50 \mathrm{cts}$. each; $\$ 5.00$ per doz.; $\$ 35.00$ per 100

Johanna Kanzlelter. Light amber-yellow changing to creamywhite, very free and distinct; $3 \frac{1}{2}$ to 4 feet. $35 \mathrm{cts}$. each.

Karl Kirsten. A tall grower, $5 \frac{1}{2}$ to 6 feet, throwing its trusses of bright poppy-red flowers high above the foliage. The individual flowers are not large, but the combination of freedom of bloom, bright color and well raised flower stems make this an exceptionally desirable sort for massing. $35 \mathrm{cts}$. each; $\$ 3.50$ per doz.

Koros. A free flowering vigorous variety with bronze foliage. The color is unusual, an attractive shade of orange-scarlet streaked and dotted with cochineal-carmine; 4 to $4 \frac{1 / 2}{2}$ feet. $15 \mathrm{cts}$. each; 81.50 per doz.

Louis Reverchon. Very pretty large flowers of cochineal-red, freely produced on vigorous plants with light bronze foliage; $4 \frac{1}{2}$ to 5 feet. 35 cts, each: $\$ 3.50$ per doz.
Mme. Noel Garonne. A very pretty salmon-flesh changing to rosysalmon; $3 \frac{1}{2}$ feet. 25 cts. each; 82.50 per doz.

Maros. Creamy white, the largest of this color. $31 / 2$ to $4 \mathrm{ft}$. $50 \mathrm{cts}$. each; $\$ 5.00$ per doz

Meteor. Enormous trusses of large bright blood-red flowers held well above the massive foliage. $5 \mathrm{ft}$. $35 \mathrm{ets}$. each; $\$ 3.50$ per doz.

Minnehaha. A distinct and novel color, a pale flesh overlaid with soft rose and cream tints; 4 feet. 15 cts. each; $\$ 1.50$ per doz.

Mistral. Remarkable for its peculiar color, the flowers when first expanding are of a pale yellow, passing to light salmon-rose as they mature. $25 \mathrm{cts}$, each; 82.50 per doz.

Mrs. Alfred F. Connard. A most remarkable variety with exquisite salmon-pink flowers of largest size, in erect and abundantly furnished heads, so freely produced as to keep up a superb showing of its fine bloom for months above the rich green foliage; 4 feet. 35 cts. each; $\$ 4.00$ per doz.; $\$ 3000$ per 100 .

Rosea Gigantea. Extra large flowers, borne in such abundance that the mass of color is truly amazing; a deep, rich rose, almost a coral-carmine; 4 to 5 feet. 20 cts, each; $\$ 2.00$ per doz.

Tout Lyon. Has attracted great attention in our trial grounds on account of its unusual color. The upper surface of the flowers is a russet-orange, while the under side is yellow, giving the whole a fantastic appearance, very free-flowering; 4 feet. $25 \mathrm{cts}$. each; 82.50 per doz.

Undine. The best of the gilt-edged sorts. A bright orange-scarlet broadly bordered with golden-yellow; habit dwarf, but very vigorous and free flowering. $25 \mathrm{cts}$. each; $\$ 2.50$ per doz.; $\$ 18.00$ per 100 .

William Saunders. A gorgeous bronze-leaved variety; flowers of a bright crimson-scarlet, often measuring 5 inches across, of re markable substance and durability. This is without question markable substance and durabilty. This is without question

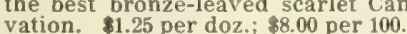

William Bates. Very large, pure yellow flowers, very freely produced and held well above the foliage, in trusses of great size; 5 feet. $50 \mathrm{cts}$. each; $\$ 5.00$ per doz.

One each of the above 22 grand varieties for $\$ 5.00$.

\section{Italian Orchid=flowered Cannas}

Allemania. Pleasing dark salmon with golden markings; 6 feet. 60 cts. per doz.; $\$ 4.00$ per 100 .

Austria. Pure canary-yellow; few reddish dots in the centre; 6 feet. 60 cts. per doz, 84.00 per 100

King Humbert. In this grand Canna we have a combination of the highest type of flower with the finest bronze foliage. Its flowers measure 6 inches in diameter, and are produced in trusses of gigantic size, of a brilliant orange-scarlet with bright red markings; the foliage is broad and massive of a rich coppery-bronze; ings; the foliage is broad and massive of a rich coppery
bold and effective: 5 feet. 81.00 per doz.; 87.00 per 100 .
Italla. Bright orange-scarlet, with broad golden-yellow border; 6 feet. $60 \mathrm{cts}$, per doz.; $\$ 4.00$ per 100 .

Mrs. Carl Kelsey. An immense orange-scarlet, wondrously flaked and striped with golden-yellow, with wavy-edged petals; entirely distinct; 6 to 7 feet. 15 cts. each; 81.50 per doz.

Pennsylvania. Intense vermilion-scarlet, overlaid with an orange sheen; 6 feet. 60 cts. per doz.; 84.00 per 100.

Wyoming. Bronzy-purple foliage with immense spikes of massive orange flowers. $60 \mathrm{cts}$. per doz.; $\$ 4.00$ per 100. 


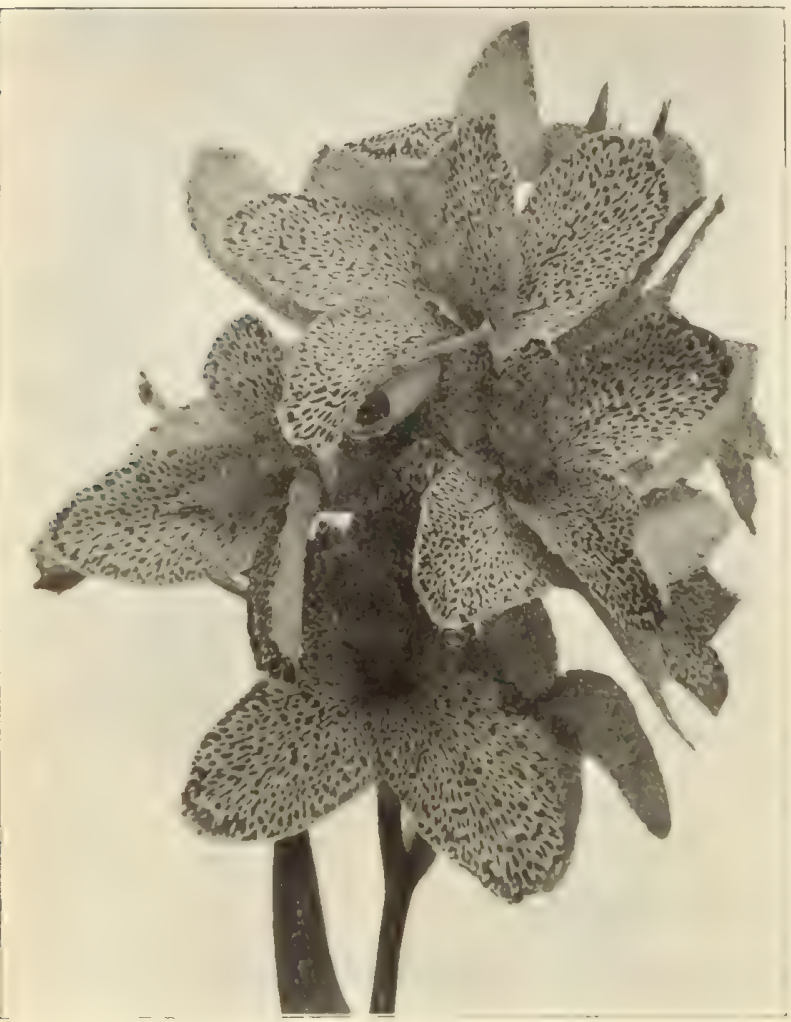

LARGE-FLOWERING CANNA

\section{Choice Standard Cannas}

All have green foliage unless otheruise specified.

Perdoz. Per 100

Alphonse Bouvier. Brilliant crimson; 6 to 7 leet

$8060 \quad$ I4 00

Alsace. Pale sulphur, changing to creamy-white; $4 \frac{3}{2}$ feet

Black Beauty. A favorite bronze; grown for the beauty of its foliage only; 5 to 6 feet

Brilliant. A bright yellow with two curling tonguelike petals of bright-red; 4 feet

Cinnabar. Cinnabar-red, edged golden-yellow; $4 \frac{1}{2}$ feet

Consul W. Vellnagel. Lemon-yellow, spotted with reddish-brown; 4 feet

Dr. Budingen. Brilliant scarlet of large size, bronze foliage; 4 feet

Dr. Robert Funcke. As bright as Scarlet Sage, large heads; $4 \frac{3 / 2}{2}$ feet

Duke of Mariboro. A valuable deep crimson; 4 feet

Egandale. A favorite bronze-leaved sort with soft currant-red flowers: 4 feet

Feuermeer. A brilliant fiery-scarlet, remarkably free

Florence Vaughan. Bright rich golden-yellow, spolted with red; 4 feet

General Merkel. Scarlet suffused with orange, base and edge of flower marbled with golden-yellow; 4 feet

Grand Chancellor Bulow. Rich deep scarlet overlaid with maroon, one of the best dark sorts; $3 \frac{1}{2}$ feet.

J. D. Eisele. Bright vermilion-scarlet overlaid with orange, a fine bedder; $3 \frac{1}{2}$ feet

Mephisto. The darkest crimson yet introduced, large sized flowers: $3^{1 / 2}$ feet

Miss Berthine Brunner. Large, pure yellow flowers, minutely spotted with orange-scarlet; $4 \frac{1}{2}$ feet

Mrs. Geo. A. Strohlein. Large amaranth-red, mas sive bronzy foliage; 5 feet
700

Choice Standard Cannas-Continued.

Per doz. Per 100

Mile. Berat. The nearest approach to a pink in a first-class bedder; 4 feet

Mme. Crozy. The popular golden-edged bright scarlet; 4 feet

60

President Meyer. A glorious Canna, with large flowers in immense trusses; color rich cherrycarmine; bronzy foliage: 4 feet

Professor Rodenwaldt. Large and effective, deep crimson scarlet, of compact habit; 3 feet. . .

Professor Romberg. A brilliant rich fiery-red, with bronze foliage; $3 \frac{1}{2}$ to 4 feet

Richard Wallace. A large canary-yellow; 5 feet.

Rubin. Ruby carmine flowers not large but produced in such profusion and so rich and glowing, Which, with the dark, bronzy-green foliage, make it one of the best bedding varieties: $3 \frac{1}{2}$ feet

Secretaire Chabanne. Distinct and pleasing salmon; very free; a fine bedder; 3 feet

Venus. Flowers of fair size, of a soft rosy pink, with a pretty mottled border of creamy yellow; $31 / 2$ feet

West Virginia, Intense crimson-scarlet with broad yellow edge; $3 \frac{1}{2}$ feet

Wilhelm Ariessinger. Pure yellow dotted carmine; $4^{1 / 2}$ feet

$\begin{array}{ll}60 & \$ 400 \\ 60 & 400 \\ 75 & 500 \\ 75 & 500 \\ 75 & 500 \\ 60 & 400 \\ & \\ 60 & 400 \\ 60 & 400 \\ 75 & 500 \\ 75 & 500 \\ 75 & 500\end{array}$

\section{New Chrysanthemum Frutescens or Marguerite.} Mrs. F. Sander.

This variety, first sent out by us two years ago, has practically replaced all other white Marguerites. It is not only the most valureplaced a variety as a cut flower, but also as a pot plant for Easter, while in some sections of the country it has also been found a profitable in some sections of the country it has also

Unmer proposition planted out of doors. Unlike all other Marguerites, its color is of the purest glistening white throughout; in size it frequently measures 5 inches across the centre of the flower is a mass of closely arranged fringed florets ; these are surrounded or edged by the broad, shining white ray petals, forming a flower which reminds one forcibly of a single, and when such is the case, they are as beautiful as the double forms; they are produced on long stems with a freedom not known in other varieties of the Marguerite.

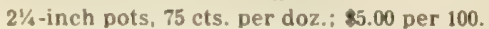

\section{Yellow Marguerite-Etoile d'Or.}

We offer the true large flowered form of the yellow Marguerite. $21 / 4$-inch pots. 85 cts. per doz.; $\$ 6.00$ per 100 .

\section{Crotons.}

We offer a choice assortment of varieties.

3-inch pots

-inch pots

5-inch pots

$\begin{array}{rr}8250 & \$ 2000 \\ 450 & 3500\end{array}$

500

500

500

500

600

$+00$

400

600

$+00$

500

500

400

400

500

600

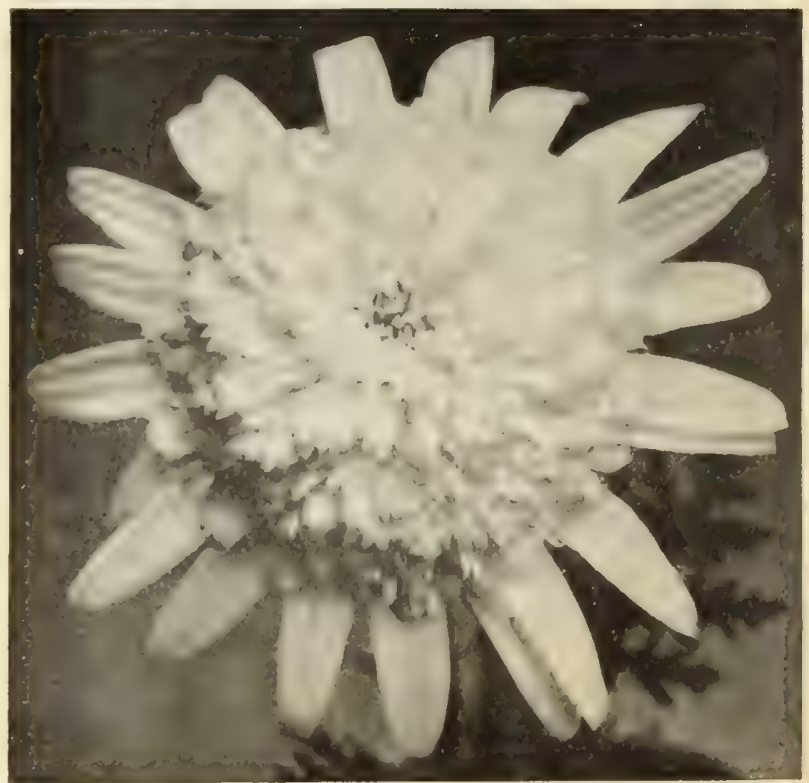

CHRYSANTHEMUM FRUTESCENS, MRS. F. SANDER 


\section{Dreer's Select Dahlias}

Dahlias True to Name.-All of the Dahlias which we offer this season have been grown at our New Riverview Nurseries under!our personal supervision, every precaution was taken to prevent errors and our customers may depend upon receiving stocks absolutely true to name.

Dahlia Roots or Plants.-Unless otherwise noted in the description of the various varieties, we supply all Dahlias in strong dormant roots, and we believe our supply this season is ample to meet all demands. However, in case the demand for certain varieties exhausts our supply of roots, we will send out strong growing plants which will give equally good results.

Dahlias for cutting. - The varieties marked with an asterisk* are those that are particulariy suited for cutting, bein $\delta$ freeflowerins sorts, with good stems and desirable colors.

\section{Special Wholesale Dahlia Catalogue}

A copy of this catalogue was sent to all our customers early in January. It describes nearly five hundred varieties, including all the latest introductions. "If you did not receive a copy or have misplaced; it we will be pleased to send you another on application.

\section{Choice Double Show and Fancy Dahlias}

For complete list see our Special Wholesale Catalogue of Dahlias. Copies free on application.

\section{Varieties marked* best for cutting.}

*A. D. Livoni. A splendid

Per doz. Per 100 A. D. Liv $\$ 100 \$ 800$

*Arabella. Light-yellow.

shaded peach-blossom. $100 \quad 800$

*Caleb Powers. Delicate

shell-pink ...... 3. 502500

Chameleon. Flesh, shad.

ing to crushed strawberry $150 \quad 1000$

Cuban Giant. Large, free, bright maroon

*Dreer's White. Introduced by us in 1909.

In color a pure glistening white, resembling in form the popular Grand Duke Alexis, while in freedom of flowering it is not surpassed by any. It has succeeded in all parts of the country and has met with much favor as a cut flower. Plants ready much favor as a cut flower. Plants ready
April 15th . . . . . . . . .

$206 \quad 1500$

Emily. Solferino, with white markings . . $100 \quad 800$

*Grand Duke Alexis. Large, massive flowers, ivory white, with a faint tinge of rose

*John Walker. An elegant pure white Lucy Fawcett. Sulphur-yellow, striped rose Mariner. Apricot, tipped with carmine-lake Miss Browning. Canary-yellow tipped with white .

$150 \quad 1000$

$150 \quad 1000$

$100 \quad 800$

1501000

$150 \quad 1000$

Miss May Loomis. White, suffused with soft rose

Peeress. Yellow with tip of fiery-red

Pendent. Crimson-maroon

Progress. Soft rosy-lake, spotted and pencilled crimson.

$150 \quad 1000$

*Princess Victoria. The earliest and freestflowering primrose-yellow.

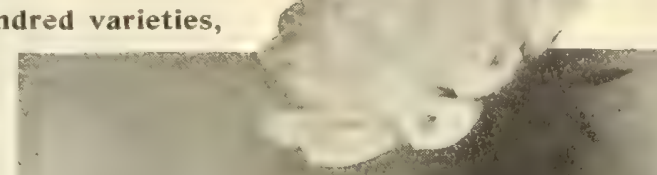




\section{Select Standard Cactus Dahlias}

The collection offered below contains all first-class standard varieties of which we have large stocks and which we are able to offer at popular prices.

For complete list see our Special Wholesale Catalogue of Dahlias, Copies free on apolication.

Varieties marked* are best for cutting.

-Aegir. Rich, warm cardinal-red

Albanie. Free, intense, brilliant crimson

*Alpenrose. Bright aniline-red

*Aml Philipde Goy. Deep salmon-red, suffused with pure scarlet

Amos Perry. Fiery-red, early and free.

Aurora. Reddish-apricot, suffused with fleshpink.

Clara. Delicate mauve with silvery-white tips

* Country Girl. Golden-yellow, suffused with salmon rose

Comet. Delicate lilac,spotted and striped rose

Dellcatissima. Hydrangea-pink.

Echo. Tyrian-rose

*Else. Base of petals buttercup-yellow gradually passing to amber. finished with a tip of tyrianrose

Erecta. Reddish-purple with chestnut shadings

"Fernand Olivet. Brilliant maroon shaded scarlet

*Flora. An ideal white Cactus

* Floradora. Brikht blood-red

* Gen. French. One of the best orange-terracottas

Gen. de Lacrolx. Solendid nower, salmon-red

"Genoveva. The best light-yellow for cutting

Gold Fasan. Chrome-yellow, suffused rosy-red

* Goldland. A splendid primrose-yellow

Goldperle. Small but very free, primrose-yellow

Goldregen. Very deep yellow of fine form

* Ootteriunke, Deep blood-red with fiery-red reflex

Per doz. Per 100

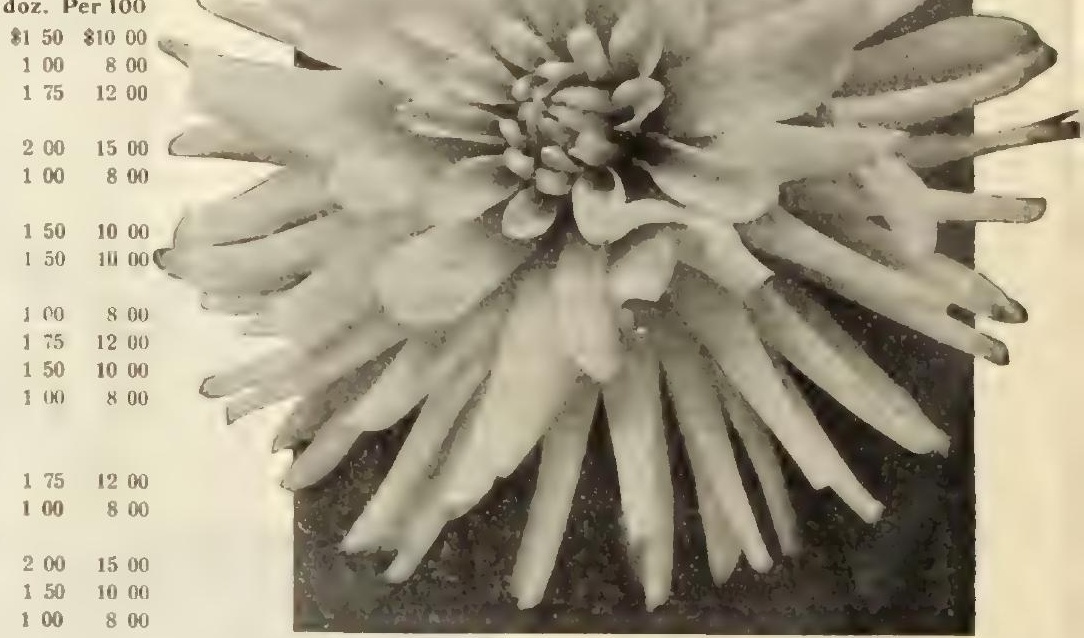

CACTUS DAILLA

Gunther. Pure white with broad twisted petals

Henri Cayeux. Very large, old-gold shading to golden yellow

* Kriemhilde. Brilliant pink, gradually shading to white at centre

"Lawine. White, with just a suggestion of blush

"Libellule, Sulphur-yellow, shaded and marked capucine-red

"Lord Minto. Pale-yellow, passing to soft salmon

"Lovely. Delicate rose with creamy-white shadings

*Marathon. Brilliant rich purple

Mars. Billiant scarlet with orange suffusion

Maurice Fuld. Bronzy-rose, striped currant-red

Mauve Queen. Delicate pure mauve shading to light centre

Mons. Quentin Bouchard. Bright scarlet of large size

Mozart. Fine crimson with scarlet shadings

Morning Glow. Crimson-yellow, suffused salmon at tips

"Mrs. Geo. Stevenson. Sparkling-yellow

Mrs. J. Emberson. Pale lemon, spotted rosy-pink

*Mrs. Edward Mawley. A fine yellow

"Otto Henschel. A good bright canary yellow

*Pius X. A splendid large white

Prima Donna. Delicate pink with white centre

*Prince of Yellows. A popular canary-yellow Princess Mary. Terra-cotta, veined reddish-

carmine

Progenitor. Bright carmine.

Reliable. Madder carmine, suffused with salmon

*Sequoia. Saffron-yellow, suffused red

* Slegstab. A rich French purple

* Soleil Couchant. Brilliant orange-scarlet

* Standard Bearer. Popular, rich fiery-scarlet. .

*Strahlen Krone. Intense cardinal-red.

Thebes. Deep oriental-red, very free.

*Weisse Dame. Snow-white, tips of petals cleft er doz. Per 100 $\$ 100 \$ 8 \mathrm{CO}$

$100 \quad 800$

$100 \quad 800$

$175 \quad 1200$

$200 \quad 1500$

$200 \quad 1500$

$100 \quad 800$

$200 \quad 1500$

$100 \quad 800$

$200 \quad 1500$

$200 \quad 1500$

$100 \quad 800$

$100 \quad 800$

$100 \quad 800$

$100 \quad 800$

200

$100 \quad 800$

$100 \quad 800$

$175 \quad 1200$

$100 \quad 800$

$100 \quad 800$

$100 \quad 800$

$100 \quad 800$

$100 \quad 800$

$150 \quad 1000$

$100 \quad 800$

$200 \quad 1500$

$150 \quad 1000$

$100 \quad 800$

$100 \quad 800$

CACTUS DAHLIA AM! PHILLIPPE GOY

$100 \quad 800$ 


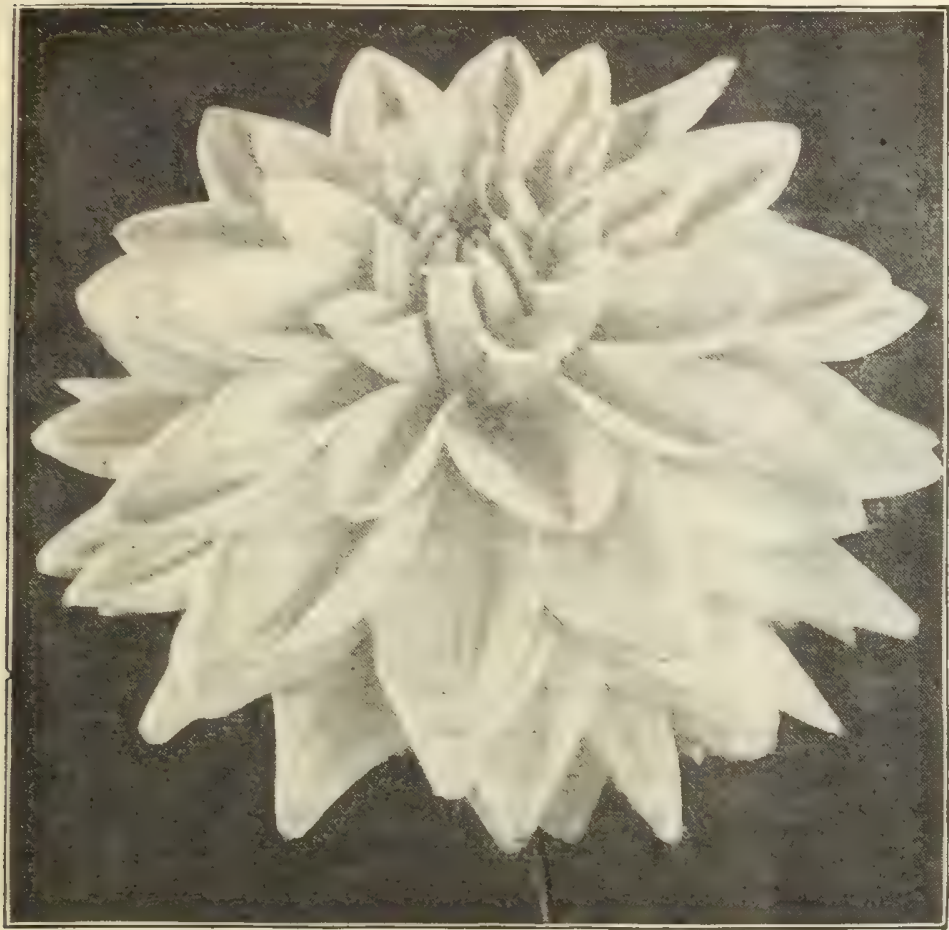

\section{German Giant Cactus Dahlias}

This is the third season that we are offering this type of Dahlias which appears to have given great satisfaction in all parts of the country. In our own fields they always attract attention on account and freedom of bloom.

For complete list see our Special Wholesale Catalogue of Dahlias. Copies free on application.

*Nerthus. Rich, glowing, bronzy orange-yellow, passing to a carmine-rose at the tips. $20 \mathrm{cts}$. each; $\$ 2.00$ per doz.; $\$ 15.00$ per 100 .

*Rheingau. Large, bold and effective brilliantscarlet. $25 \mathrm{cts}$. each; $\$ 2.50$ per doz.

*Rheinkonig. Pure snow-white flowers of splendid; form. 20 cts. each; $\$ 2.00$ per doz.; $\$ 15.00$ per 100 ,

*Vater Rhein. Flowers frequently 7 inches in diameter, the petals are broad, curled and twisted, forming an ideal flower, the color is yellow suffused with salmon-rose. 35 ets. each; $\$ 3.50$ per doz.; $\$ 25.00$ per 100 .

DECORATIVE DAHLIA, MMF. VAN DEN DAELE

\section{Decorative Dahlias of Recent Introduction and Special Merit}

For complete list see our Special Wholesale Catalogue of Dahlias. Copies free on application.

Varieties marked * are best for cutting.

Per doz. Per 100

Black Beauty. Deep velvety-maroon; almost black $\$ 150 \$ 1000$

* Catherine Duer. Iridescent-red.

* Clifford W. Bruton. A fine, bright yellow

*Caronna. A miniature pure white

Dragon d'Or. A soft yellow

-Delice. Its beautiful soft, yet lively color, a glowing rose-pink, together with its perfect shape, and stout, stiff stems, makes this one of the most valuble for cutting. Plants ready April 15th

Eureka, Large, deep rose

F. L. Bassett. Carmine-purple . 100800 Gold of Ophir. Rich old-gold . ... $100 \quad 800$

*Henry Patrick. Beautiful pure white $100 \quad 800$

*Jack Rose. Brilliant crimson-red . $\quad 150 \quad 1000$

Juno. A rich velvety reddish-brown $150 \quad 1000$

Kind's Pink. Described by the intro-

ducer as an improved Sylvia

* Lyndhurst. Brilliant cardinal-red, a fine cut flower

*Miss Minnie McCullough. Soft yellow, overlaid with bronze .....

Monte Rose. A delicate rosy-mauve, tinted carmine

*Mont Blanc. Very large flowering. creamy-white

$150 \quad 1000$

$100 \quad 800$

$200 \quad 1500$

$150 \quad 1000$

$200 \quad 1500$

* Mrs. Roosevelt. Of immense size and remarkably free-flowering. Of a delicate silvery rose. Plants ready April 15th

$100 \quad 800$

$100 \quad 800$

$175 \quad 1200$

Mme. Van den Daele. A charming soft rose shading to white in the centre

Orange King. Rich, glowing orange scarlet

Ouray, Rich deep velyety-maroon

*Princess Victoria Louise. Bright solferino-red

Rayon d'Or. Bright terra-cotta

Riese von Stuttgart. Probably the largest Dahlia

of this type, in color a bright blood-red, shading of this type, in color a bright blood-red, shading deeper to the centre

Sea Shell. A pretty miniature varying in color from shell-pink to crimson-pink

Senor Leon Perez. Delicate mauve-pink, shading to white at the centre

Souvenir de Gustave Doazon. Of mammoth proportions, pure red in color

"Sylvia. Soft pleasing mauve-pink.

Seven Oaks Scarlet. Vivid orange-scarlet.

$175 \quad 1200$

$150 \quad 100$
$100 \quad 800$
Souvenir de Maurice Rivoire. A deep amber suffused and marked with raspberry-red at the tips

Triomphe de Schmitt. Carmine-red, flamed to-

wards the centr.

*William Agnew.

William Agnew. Rich carmine-red

$100 \quad 800$ $\$ 150 \$ 1000$ er doz. Per 100
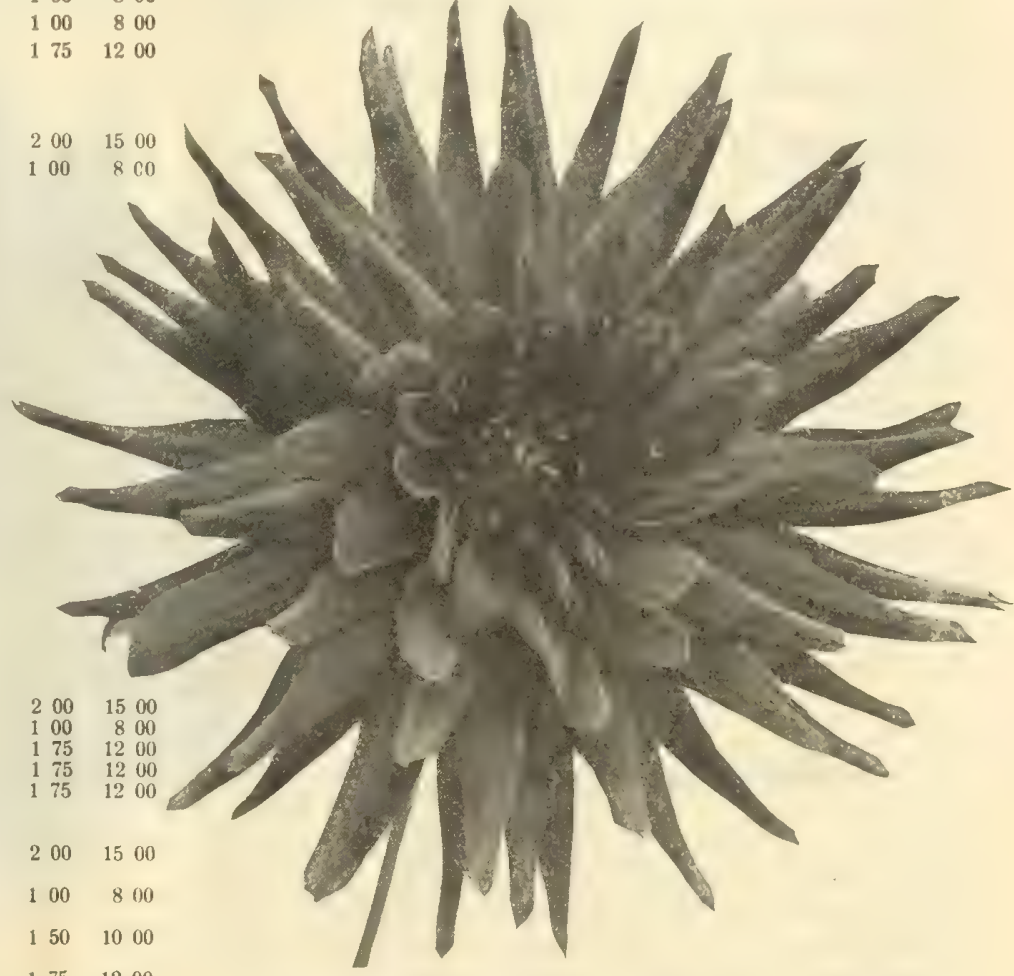

$85 \quad 600$ 


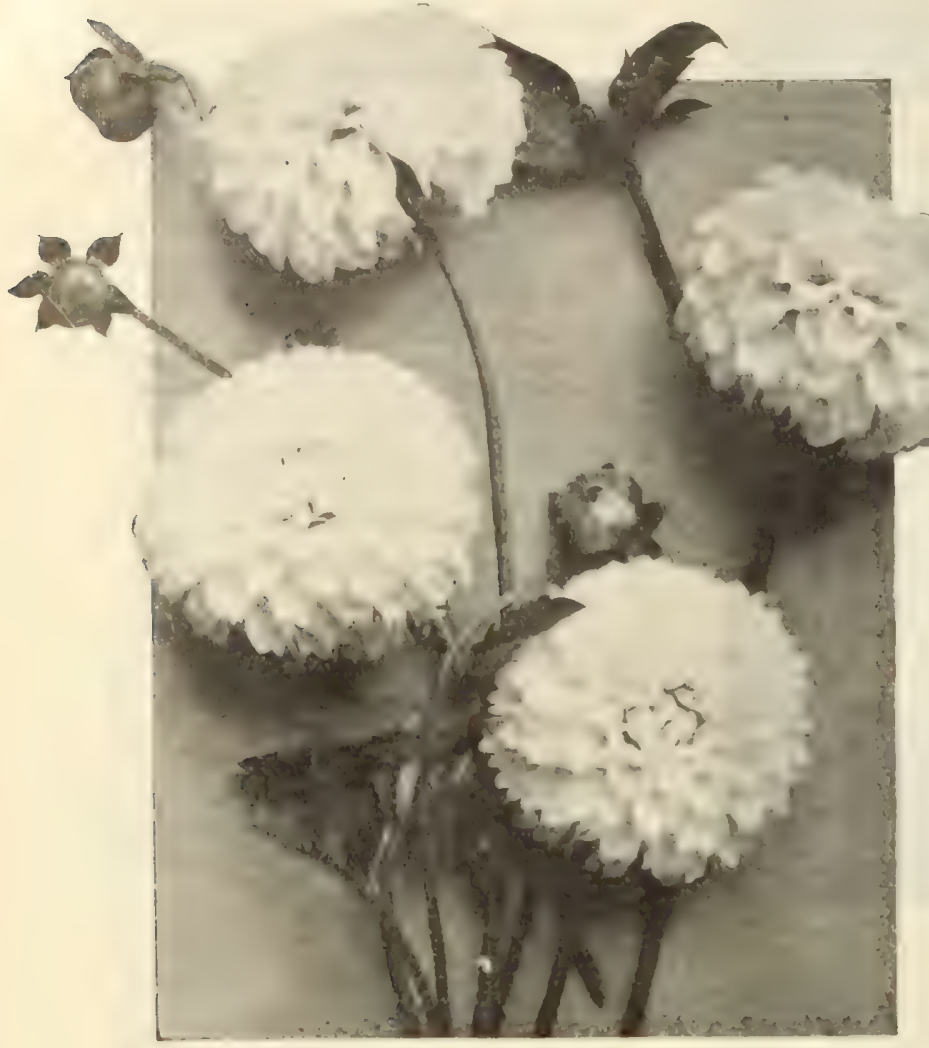

DOUBLE POMPON DAHLIAS

\section{Double Pompon Dahlias}

For complete list see our Special Wholesale Catalogue of Dahlias. Coples free on application.

Annie Doncaster. Light yellow, suffused with pink.

Blumenreich. Deep amber, suffused with red. Catherine. Well formed primrose-yellow. Darkness. Deep velvety-maroon.

Kleine Domitea. Orange buff; always in flower. Little Herman. Deep carmine, shaded garnet. tipped white.

Nerissa (New). A perfect gem, most perfect in shape, always covered with flowers of a pleasing mauve-pink color. Plants ready April 15th. Salamander. Golden-yellow, tipped orange-red. "Snowclad. A fine pure white.

Vivid. Vivid brilliant scarlet.

Ware's Fashion. Orance shaded buff.

Ware's Mars. Beautiful deep red of fine form.

Price. Any of the above. $10 \mathrm{cts}$. each; $\$ 1.00$ per doz.: $\$ 8.00$ per 100 .

\section{Dahlias in Mixture}

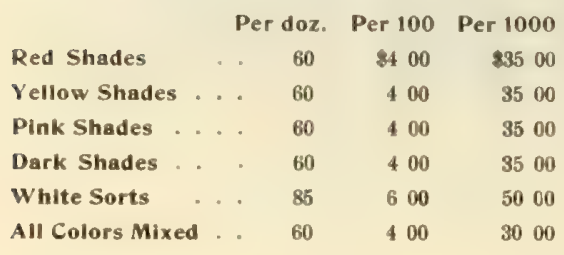

\section{Dreer's Select Paeony=Flowered Dahlias}

This beautiful type is now very popular. The artistic flowers are very large, and are best compared to the semi-double Pæonies in general form. They all flower very freely, and are borne on long, strong stems, making excellent material for cutting as well as for garden decoration.

For complete list see our Special Wholesale Catalogue of Dahlias. Copies free on apolication.

Antoine Rivoire. A brilliant ox-blood red .

Each Dox.

Feldberg. A splendid large white.......

$30 \quad 200$

Geisha. The showiest and most attractive of this type yet introduced, of an effective and rich combination of scarlet and gold. Plants ready

April 15th. 825.00 per $100 \ldots . . . . .35 \quad 350$

Germania. Brilliant strawberry-red ..... 20200

Mannhelm. Salmon-pink illuminated with gold $\quad \begin{array}{lll}20 & 175\end{array}$

Queen Emma. Mallow or Hollyhock pink, the

inner petals banded with gold.. $\$ 12.00$ per 100

Queen Wilhelmina. Pure white with yellow centre. $\$ 15.00$ per 100

Rlesen Edelwelss. Pure glistening white

Solfatere. Brilliant carmine with yellow centre. . $\quad 20 \quad 175$

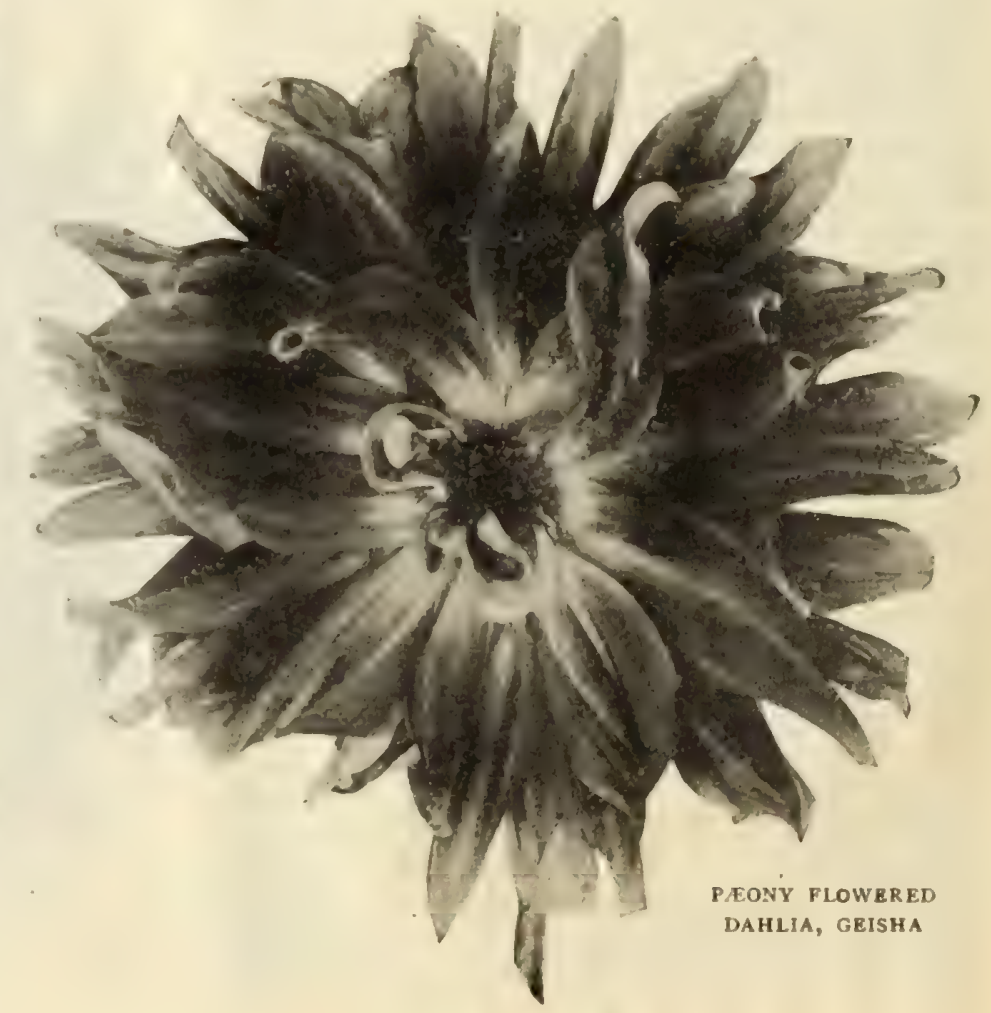




\section{Collerette Dahlias}

Wonderfully improved forms with large flowers and delightful color combinations. The flowers are single, having one row of petals with an additional row of short petals around the disc, which forms a frill or collar which is usually of a different color from the rest of the flower.

For complete list see our Special Wholesale Catalogue of Dahlias. Coples free on application.

Comte Cheremeteff. Vermilion-red shading to orange at tips; creamy-white collar.

Each Per doz.

Comte Nodler. Deep satiny purple-garnet with sulphur-yellow centre, collar rays also sulphur-yellow shading to white on the tips

Duchesse Melzi d'Eril. Brilliant orange-scarlet suffused with vermilion; collar petals a mottling of blush-white, purplish-violet and red

Exposition de Lyon. Bright garnet, yellow collar petals

Goldstern. Both ray and collar petals canaryyellow

$\$ 020 \$ 175$

Harman Payne. Brownish-red suffused with yellow on the edges, collar petals white with carmine markings ........

Henri Farman. Cardinal red frequently edged with creamy-yellow. Collar petals

Mme. Gygax. Bright cochineal-red, passing to yellow tips; primrose-yellow collar petals.

Mme. E. Poirier. Deep purple, suffused with lighter shades which give it a violet-blue effect; collar

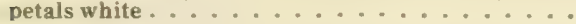

Mme. Capron. Brilliant reddish-purple, collar petals of same color but striped and marked with white

Maurice Rivoire. Ox-blood red; pure white fringed collar

Rheinkrone. Satiny-crimson petals of cactus form with long collar petals carmine-rose marked and tipped white

Sirius. Rich garnet with pure white collar petals

Souvenir de Rene Bernardeau. Bright carmine, collar petals of same color; suffused with carmine

Souvenir de Chabanne. Ground color lemon yellow, with coral red markings. Collar petals lemon* yellow tipped white

$20 \quad 175$

$20 \quad 175$

$20 \quad 20$

$20 \quad 175$

$20 \quad 200$

150

20

15150

$20 \quad 175$

10100

$20 \quad 175$

$20 \quad 175$

$20 \quad 200$

$20 \quad 200$

GROUP OF

COLLERETTE

DAHLIAS
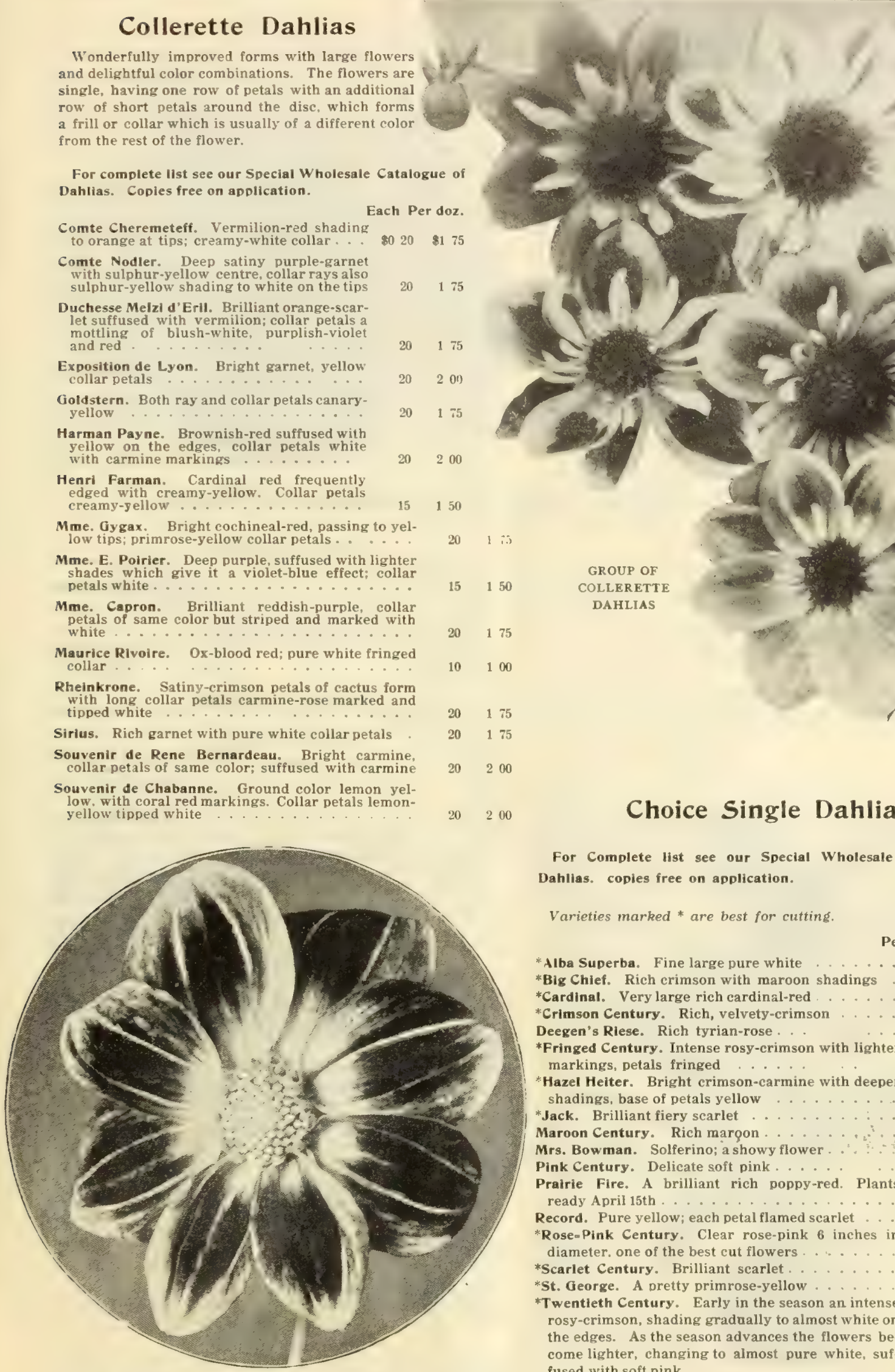

For Complete list see our Special Wholesale Catalogue of Dahlias. copies free on application.

Varieties marked * are best for cutting.

Per doz. Per 100

* Alba Superba. Fine large pure white

$\$ 100 \$ 800$

*Big Chief. Rich crimson with maroon shadings . $\quad 85600$

*Cardinal. Very large rich cardinal-red . . . . 1501000

*Crimson Century. Rich, velvety-crimson.... . 85600

Deegen's Riese. Rich tyrian-rose. . $-150 \quad 1000$

*Fringed Century. Intense rosy-crimson with lighter markings, petals fringed

Hazel Heiter. Bright crimson-carmine with deeper shadings, base of petals yellow " " " " " "

*Jack. Brilliant fiery scarlet

Maroon Century. Rich maroon

Mrs. Bowman. Solferino; a showy flower

$175 \quad 1200$

$200 \quad 1500$

1751200

85600

$100 \quad 800$

Pink Century. Delicate soft pink...... . 1501000

Prairie Fire. A brilliant rich poppy-red. Plants ready April 15th..................

Record. Pure yellow; each petal flamed scarlet. . .
*Rose=Pink Century, Clear rose-pink 6 inches in

* Rose-Pink Century. Clear rose-pink 6 inches in diameter, one of the best cut flowers.

* Scarlet Century. Brilliant scarlet.

* St. George. A pretty primrose-yellow

*Twentieth Century. Early in the season an intense rosy-crimson, shading gradually to almost white on the edges. As the season advances the flowers become lighter, changing to almost pure white, suffused with soft pink.

1501000

100800

$175 \quad 1200$

$175 \quad 1200$

$100 \quad 800$ 


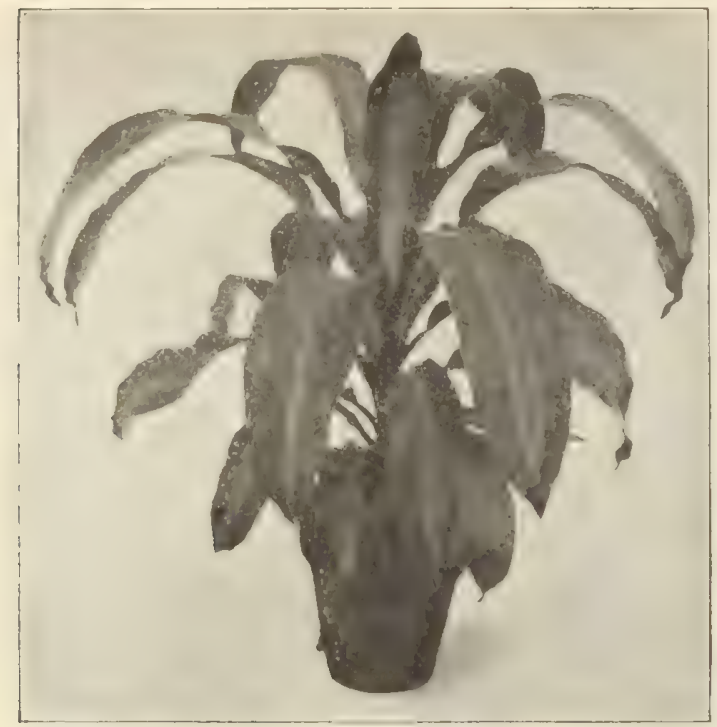

DRAC RNA MASSANGEANA

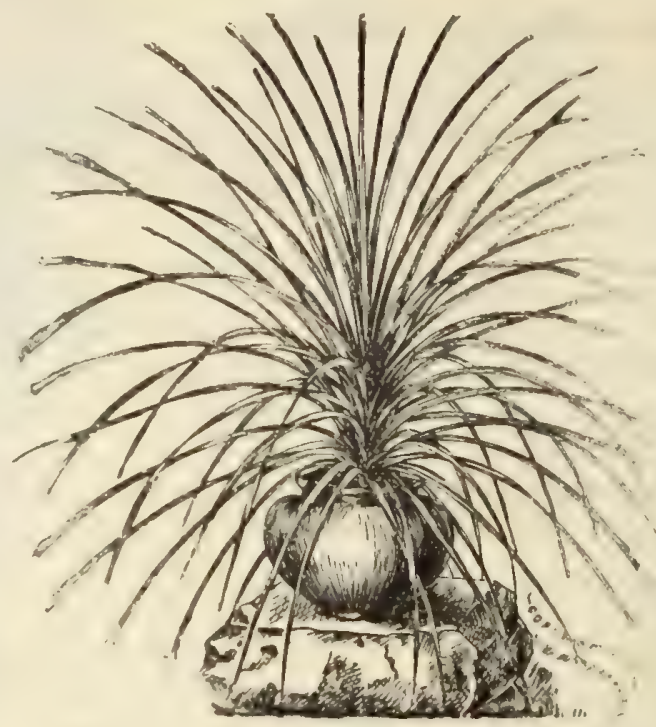

DRACAENA INDIVISA

\section{DREER'S DECORATIVE DRACAENAS}

\section{We have an exceptionally fine lot of the various varieties offered below.}

Dracena Amabilis.

A splendid variety to grow into large specimens, foliage green coloring to a creamy white with pink suffusion and markings.

$21 / 4$-inch pots . . . . . . 32.00 per doz.; $\$ 15.00$ per 100 3-inch

\section{Dracana Anerliensis.}

Broad deep bronzy-red foliage, becoming marked with white. $2 \%$-inch pots

Dracana Baptistii.

A beautiful variety in all stages of growth, broad recurved foliage deep green with metallic suffusion striped and marked with creamy yellow and pink.

$2 \%$-inch pots 3-inch

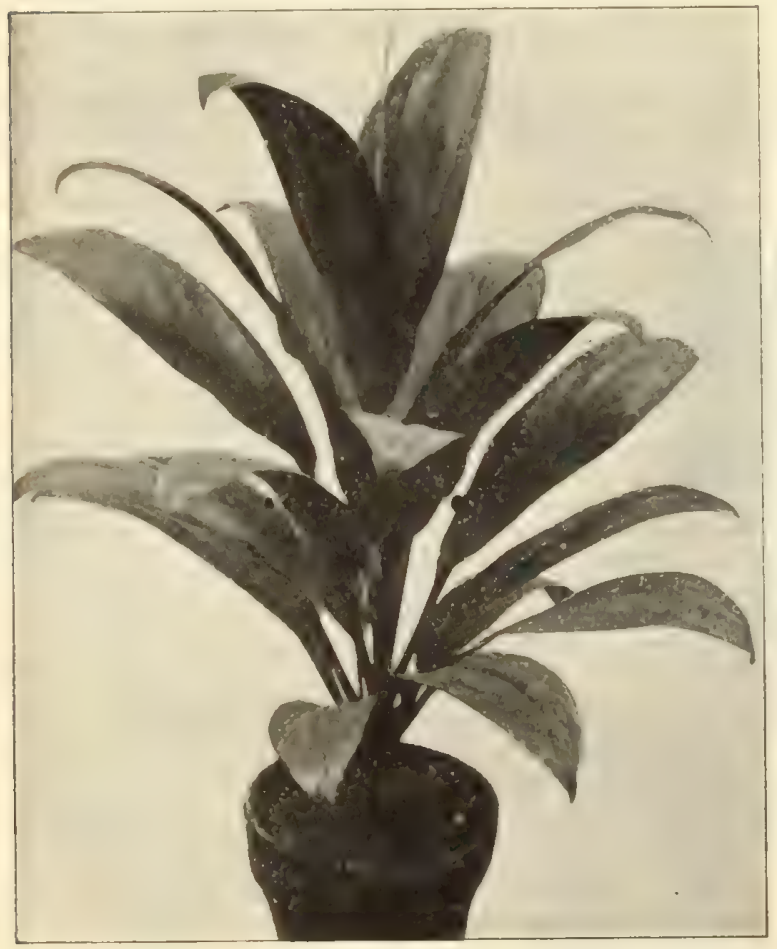

DRACAENA DESMETIANA
Dracaena Desmetiana.

Has become very popular, bold dark green foliage which becomes beautifully suffused with pink and white.

4-inch pots.

Dracana Fragrans.

A splendid lot of young plants for growing on.

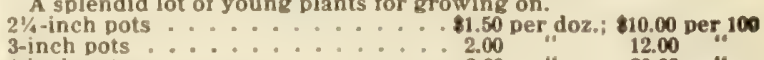

4-inch pots

$\begin{array}{lll}2.00 & 12.00 \\ 3.00 & 20.00\end{array}$

Dracæna Godseffiana.

A useful plant for use in Fern-dish work. 21/4-inch pots, \$1.24 per doz: 88.00 per 100.

z-inch pots .......... 20.60 per doz.; 4.00 per 100

4-inch

5 -inch

6-inch

7-inch

8-inch

8-inch

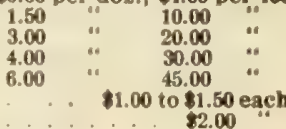

Dracana Lord Wolseley.

The best of the high-colored narrow-leaved varieties.

$21 / 4$-incb pots ........... $\$ 2.00$ per doz.; 815.00 per 100 3-inch

3.50

$\$ 25.00$ per 100

Dracæna Lindeni.

4-irch pots

5 -inch

Dracana Massangeana.

Each

4-inch pots

-inch

50

6-inch

Dracana Mme. Winkelman.

Broad bronzy foliage coloring crimson.

$21 / 4$-inch pots .............. 2.50 per dozen 3 -inch

\section{Dracæna Rotheana.}

An old but scarce variety with heavy green foliage. 5-inch pots. 50 cts. each.

Dracana Shepherdii.

Foliage green, becoming striped with a peculiar bronzy orange hue, makes a fine large specimen.

$2 \frac{1}{6}$-inch pots .......... . . . . 82.00 per dozen 3-inch

Dracana Stricta Grandis.

A splendid bright colored variety somewhat on the style of Terminalis.

$2 \frac{1}{4}$-inch pots ...................... per dozen 3 inch

Dracana Terminalis.

We have a splendid stock of this popular variety.

$21 / 4$-inch pots ...... 81.25 per doz.; 88.00 per 100 3-inch

-inch

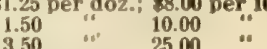

Dracana Youngii.

Makes a splendid specimen, bright green in the young state changing to a pleasing metallic bronze.

$2 \%$-inch pots

$\$ 2.00$ per dozen 


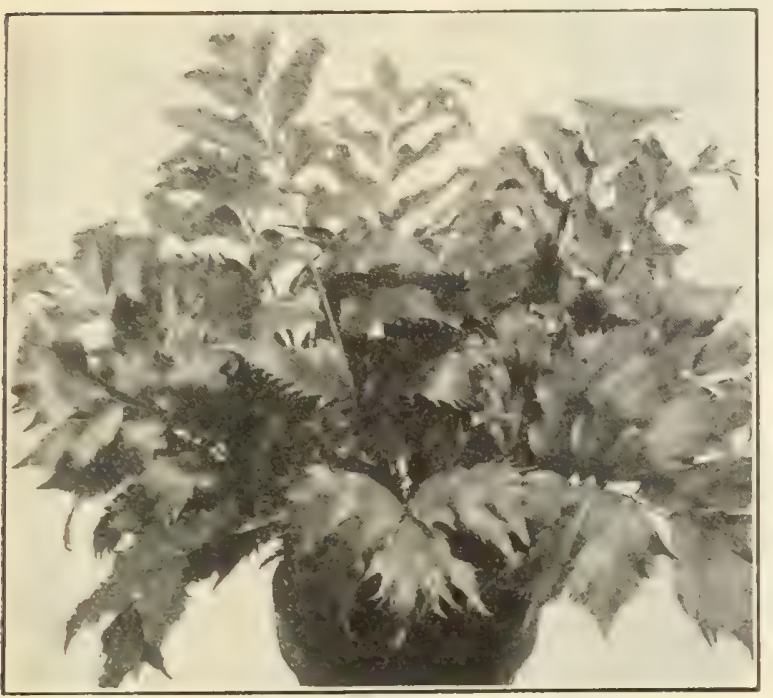

CYRTOMIUM ROCHFORDIANUM

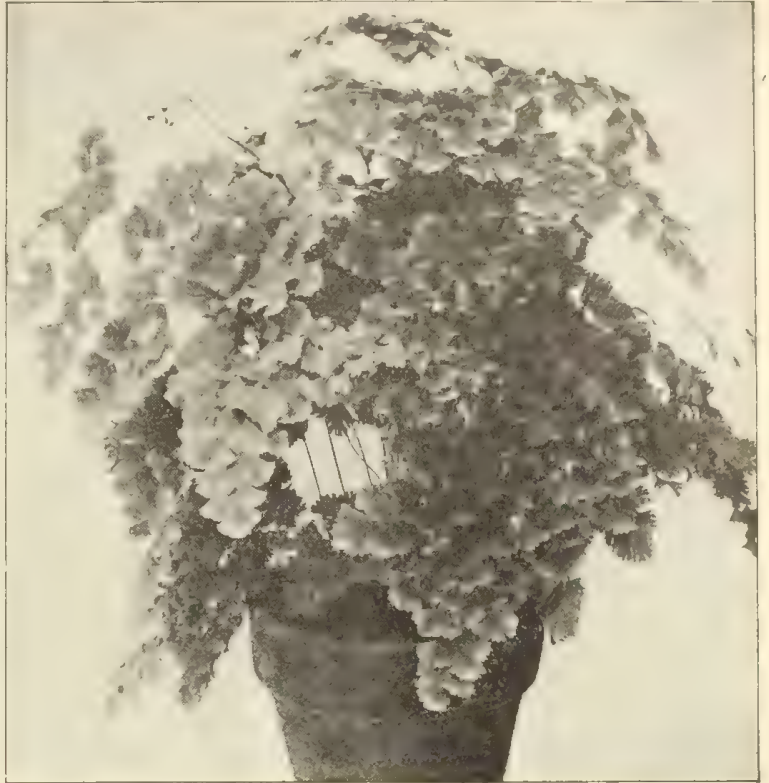

THE GLORY FERN (Adiantum Farleyense Gloriosa)

\section{DREER'S FINE FERNS}

\section{VARIETIES OF SPECIAL MERIT}

\section{Adiantum Farleyense Gloriosa.}

The Glory Fern or Ruhm von Mordrecht.

The Fern Which Will Revolutionize the Cut Frond Business.

For the grower of Ferns for cutting this new Maiden Hair will undoubtedly prove a most important addition; it closely resembles Adiantum Farleyense and will make a splendid substitute for that fancy variety and it can be produced at much less cost, as it will thrive under conditions in which Adiantum Farleyense could not exist.

Anyone who successfully grows the ordinary varieties of Adiantum such as Cuneatum, Croweanum and Hybridum, can grow it under precisely the same conditions given to these sorts.

We have in stock at the present time about 7500 plants in 3 -inch pots which we offer at

$\$ 2.00$ per doz:; $\$ 15.00$ per $100 ; \$ 140$ per 1000 .

After these are sold we will have no further supply until about Sept. 1st, and we will book orders for delivery at that time for $21 / 4$. inch pots at same price as the 3 -inch stock offered above.

\section{Adiantum Croweanum.}

We are the sole distributers of Mr. Crowe's stock of this valuable fern.

This for many years has been the standard variety for general commercial work. We will have a nice lot of 3 -inch pots. $\$ 2.00$ per doz.; $\$ 15.00$ per $100 ; \$ 140.00$ per 1000 .

\section{Adiantum Hybridum.}

Preferred by some growers to A. Croweanum. A large thrifty stock of $2 \frac{1}{4}$-inch pots. 85 cts. per doz.; $\$ 6.00$ per $100 ; 50.00$ per 1000

\begin{tabular}{|c|c|c|c|c|}
\hline & & Adiantum & Farleyense. & z. $\mathrm{Pe}$ \\
\hline inch pots & $\begin{array}{l}\cdots \\
\cdots \\
\cdots\end{array}$ & 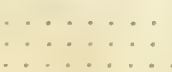 & $\because \cdots$ & $\begin{array}{rrr}\$ 350 & \$ 2500 \\
500 \quad 40 & 00 \\
75 \text { cts. each }\end{array}$ \\
\hline
\end{tabular}

\section{Cibotium Schiedei.}

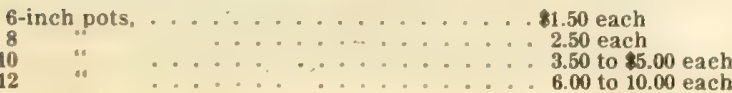

\section{Cyrtomium Rochfordianum. The Crested Holly Fern.}

The Most Valuable Decorative Fern of Recent Introduction. A most important addition to our list of Ferns. Its foliage is of a rich, deep, glossy green color, the pinnæ or leaflets besides being wavy or undulated are also deeply cut or toothed, giving the plant a graceful light appearance, which make it valuable not only as a dish Fern but for decorative work and apartment use.

We offer for delivery after July 1 st $2 \frac{1 / 4}{4}$-inch pots, $\$ 3.00$ per 100 ; $\$ 25.00$ per 1000 .

Also a limited lot of flats about 200 plants each, at $\$ 2.00$ per flat.

\section{Pteris Childsi.}

This beautiful variety is to Pteris what Farleyense is to Adiantums, and like that variety produces no spore, so that propagation is by the rather slow method of division, which will keep it a rare variety. The plant is of strong growth, attaining a height of about 20 inches; fronds large, pinnæ deeply dentated and undulated, tips crested. Makes a beautiful specimen for exhibition Specimen plants, 75 cts, each.

\section{Polypodium Glaucum Cristatum.}

A perfect gem and entirely distinct from all other Ferns, and a splendid subject to grow into specimen plants; the fronds attain a height of about 2 feet, and are of a metallic glaucous-blue color, with the edges of the pinnze wavy and crispate, giving the plant a with the edges of the pinnze wavy and cri

Platyceriums (Elk's Horn Fern).

Alcicorne Majus

Each Angolense.

Orande.

Stemmaria.

Veitchili.

Willinckit

New Golden-leaved Selaginella Emiliana.

One of the prettiest of the Selaginellas for use in fern dishes as One of the prettiest of the Selaginellas for use in fern dishes as other foliage plants. Rich golden yellow foliage, very distinct. 


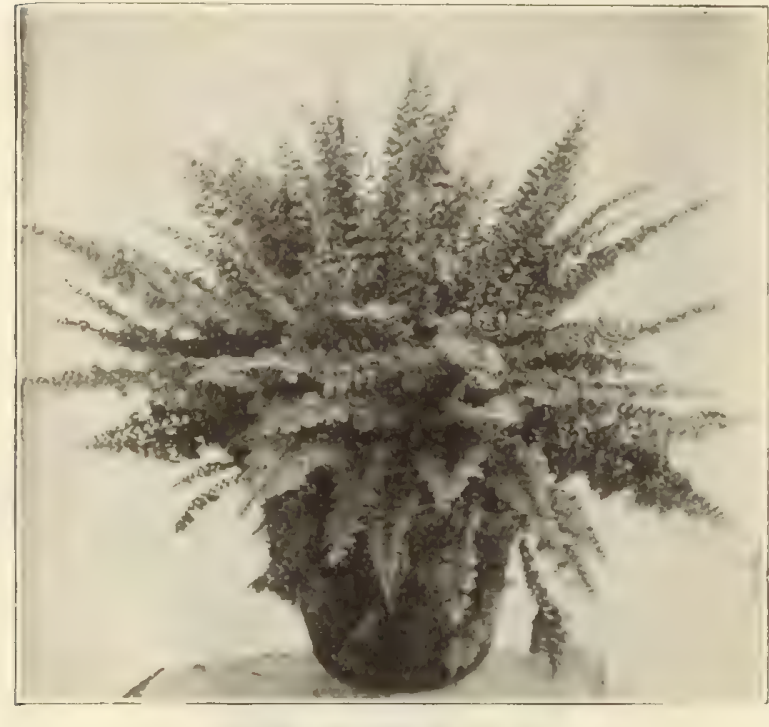

NEPHROLEPIS SCHOLZELI

\section{DREER'S FINE FERNS}

\author{
[CONTINUED]
}

\section{The Boston Fern and Its Varieties.}

\section{Nephrolepis Bostoniensis (The Boston Fern).} $2 \frac{1}{4}$-inch pots, 75 cts. per doz.: $\$ 5.00$ per $100 ; \$ 40.00$ per 1000 .

Nephrolepis Schoizeli (Crested Scott Fern). $2 \%$-inch pots, 75 cts. per doz.; $\$ 5.00$ per $100 ; \$ 40.00$ per 1000.

Nephrolepis Scottil (Scott Fern).

$2 \%$-inch pots, 75 cts. per doz.; $\$ 5.00$ per $100 ; 40.00$ per 1000 .

\section{Nephrolepis Whitmani.}

The Improved Ostrich-Plume Fern. $2 \frac{1}{4}$-inch pots, 75 cts. per doz.; $\$ 5.00$ per $100 ; 840.00$ per 1000 .

\section{Nephrolepis W. K. Harris.}

A strong growing form of Bostoniensis, splendid to grow into large specimens. The edges of the pinnæ are wavy, giving it a graceful appearance.

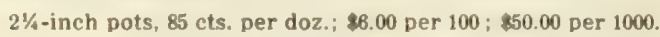

\section{Nephrolepis Superbissima.}

A most distinct variety and very useful in the smaller size of 5 -

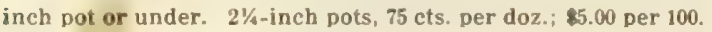

Nephrolepis Elegantissima, Improved.

2\%/4-inch pots, $\$ 1.00$ per doz.; 87.00 per 100 .

\section{Mixed Ferns for Dishes}

We have at all times a good supply of these. $2 \frac{1 / 4-i n c h}{\text { pots, }} \mathbf{2 3 . 0 0}$ per $100 ; \$ 25.00$ per 1000 .

\section{General Collection of FINE FERNS}

\begin{tabular}{|c|c|c|c|c|c|c|c|c|c|}
\hline \multirow{2}{*}{\multicolumn{2}{|c|}{ Adiantum }} & & & & & \multicolumn{2}{|r|}{ Inch Pots } & \multicolumn{2}{|c|}{ Per 100 Per 1000} \\
\hline & & Emulum.... & . & . & . & - & $\mathbf{s}$ & $\$ 600$ & \\
\hline . & & Bellum..... & . . & . & . & . & $21 / 4$ & 500 & \\
\hline " & & Cuneatum .... & $\cdots$ & . & - & - & $2 \%$ & 350 & $\$ 3000$ \\
\hline “ & & .. & . & • & . & . & 3 & 600 & 5000 \\
\hline$"$ & & Varieg & gatu & $\mathbf{u m}$ & & . & $21 / 4$ & 500 & \\
\hline " & & Caudatum... . & $\cdots$ & . & & $\cdot$ & 3 & 1000 & \\
\hline 18 & & Delabriformis . . & . . & . & . & . & 3 & 1000 & \\
\hline$"$ & & Hybridum . . . & $\therefore$ & . & , & - & $2 \frac{1}{4}$ & 600 & 5000 \\
\hline " & & $\begin{array}{c}\text { Machropyllum al } \\
\text { striatum. }\end{array}$ & lba- & . & · & $\cdot$ & $2 \%$ & 600 & \\
\hline$"$ & & Mundulum ... . & . . & . & . & . & $21 / 4$ & 500 & \\
\hline ." & & Reginae ... & . . & . & 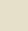 & $\cdot$ & $2 \frac{1}{4}$ & 800 & \\
\hline " & & Rochfordlanum. & . . & . & - & . & $2 \%$ & 400 & \\
\hline " & & Scutum .... & . . & 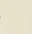 & . & . & 3 & 1000 & \\
\hline " & & St. Catherina . & . . & . & . & . & $21 / 4$ & 1000 & \\
\hline " & & Weigandi .... & $\therefore$ & . & & . & $2 \%$ & 500 & \\
\hline Alsoph & hila $A$ & Australls. Ready & Jul & ly & . & . & $21 / 4$ & 800 & \\
\hline Aspidi & um ? & Tsussimense. . & . & & . & . & $2 \%$ & 300 & 2500 \\
\hline Blechr & num & Occidentale... & . . & . & . & . & $21 / 4$ & 350 & 3000 \\
\hline$"$ & & Braxillensis ... & $\therefore$ & . & . & . & $21 / 4$ & 350 & 3000 \\
\hline avall & & IjIensis Major. & . . & - . & . & . & 4 & 2500 & \\
\hline ". & & " Plumosa & . & . . & . & . & 4 & 3500 & \\
\hline$"$ & & Iffinis ..... & . & - . & . & $\cdot$ & 3 & 1000 & \\
\hline$"$ & & Mariest Crispa. . & . . & . & . & . & 4 & 2500 & \\
\hline Dictyo & ogran & mma Japonica. . & . . & . & . & . & 3 & 1200 & \\
\hline Oonior & phleb & blum Sub-auricula & latur & $m$ & . & . & $2 \%$ & 1000 & \\
\hline Lastre & Arl & Istata Variegata . & $\cdots$ & . & - & . & 3 & 600 & \\
\hline Lomar & $\mathrm{rlacl}$ & 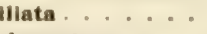 & & & . &. & $2 \%$ & 350 & 3000 \\
\hline Lygod & lium. & Japonicum... & . & . & . & . & $21 / 4$ & 400 & 3500 \\
\hline " & & Scandens..... & $\cdots$ & . & . & . & $2 \%$ & 400 & " \\
\hline Polypo & odiun & m Areolata ... & . . & . & . & . & $2 \%$ & 350 & \\
\hline & & Aureum . . . & . & . & - & . & $2 \%$ & 350 & 3000 \\
\hline Polyst & tichur & im Setosum.... & . . & . . & . & - & $2 \%$ & 400 & \\
\hline Pteris & Adie & lantoldes..... & . . & . & - & . & $2 \%$ & 300 & 2500 \\
\hline$"$ & Alex & xandra .... & $\cdots$ & . & . & . & $2 \frac{1}{4}$ & 300 & 2500 \\
\hline$"$ & Argy & yrae .......... & $\cdots$ & . & . & . & $2 \%$ & 300 & 2500 \\
\hline$"$ & Cret & tica Albo Lineata & $\therefore$ & . & . & . & $2 \%$ & 900 & 2500 \\
\hline$"$ & Flab & bellata... : . & . & . & . & . & $21 / 4$ & 300 & 2500 \\
\hline$"$ & Inter & rnata. ..... & . . & . & . & . & $2 \%$ & 300 & 2500 \\
\hline$"$ & Mag & mifica $\ldots \ldots$ & . . & . & . & . & $21 / 4$ & 300 & 2500 \\
\hline$\because$ & Ouv & rardil ...... & . & . & . & . & $2 \frac{1}{4}$ & 300 & 2500 \\
\hline ". & May & 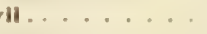 & . . . & - & . & & $2 \%$ & 300 & 2500 \\
\hline .. & Serr & rulata.... & . . & . & . & . & $21 / 4$ & 300 & 2500 \\
\hline “ & & Cristata. . & $\cdots$ & . & . & . & $21 / 4$ & 300 & 2500 \\
\hline 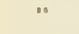 & Tren & 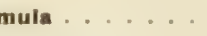 & $\cdots$ & . & . & . & $2 \%$ & 300 & 2500 \\
\hline$"$ & Vict & 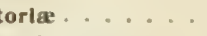 & . . & & & . & $2 \%$ & 900 & 2500 \\
\hline$"$ & Wils & 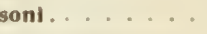 & . . & . & 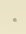 & . & $2 \%$ & 300 & 2500 \\
\hline ". & Wim & nsettI Multiceps. & $\cdots$ & - & - & " & $2 \%$ & 300 & 2500 \\
\hline$"$ & Wim & nsetti .......... & . & - & & & $2 \%$ & 300 & 2500 \\
\hline talo & bium & Cicutarium & & & & & $21 / 4$ & 600 & \\
\hline
\end{tabular}

\section{Ferns in Flats.}

We are now booking orders for Ferns in flats for delivery after April 1st at $\$ 2.00$ per flat. Varieties marked with an (*) can be supplied at once if desired.

These flats contain about two hundred plants each, only one variety being in a flat and we cannot supply less than a full flat of any one sort.

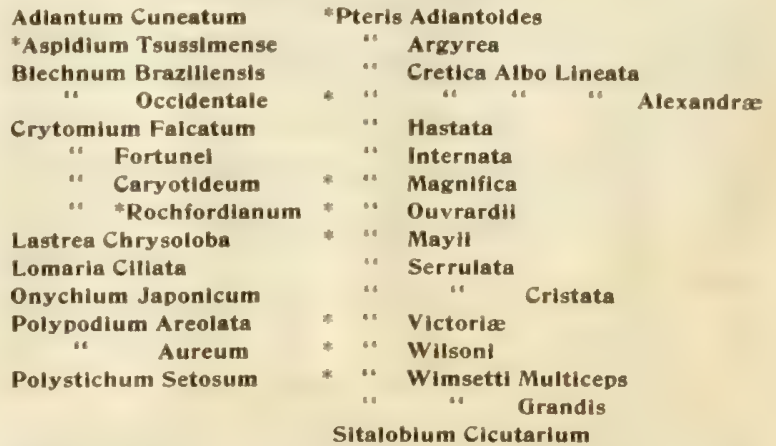

We also offer a limited stock of Adiantum Hybridum in flats at \$3.00 per flat. 


\title{
The New Hydrangeas
}

\author{
The Great Easter Novelty \\ of the Year
}

All of the varieties here offered have been tested by us under ordinary conditions as to their adaptability to forcing for Easter, with the intention of discarding any that proved unworthy.

To our surprise and gratification, all have proven themselves valuable additions.

While it is true that the average florist may ultimately select only a half dozen sorts as meeting his particular requirements, it is manifestly impossible for us to make the final selection for him.

In view of the condition explained above, we continue to offer the full set at a special price to enable the grower to try all the varieties and determine for himself which most nearly meets his particular requirements. These are all supplied in dormant plants.

Avalanche. A splendid large white, which has made a reputation for itself during the past two seasons; an easy variety to force. $2 \frac{1}{4}$-inch pots, $\$ 0.75$ per doz.; $\$ 5.00$ per 100 . $\begin{array}{llllll}5 & \text {. } & \text { " } & 2.50 & 4 & \\ 6 & & & 4.00 & \text { " } & 30.00\end{array}$

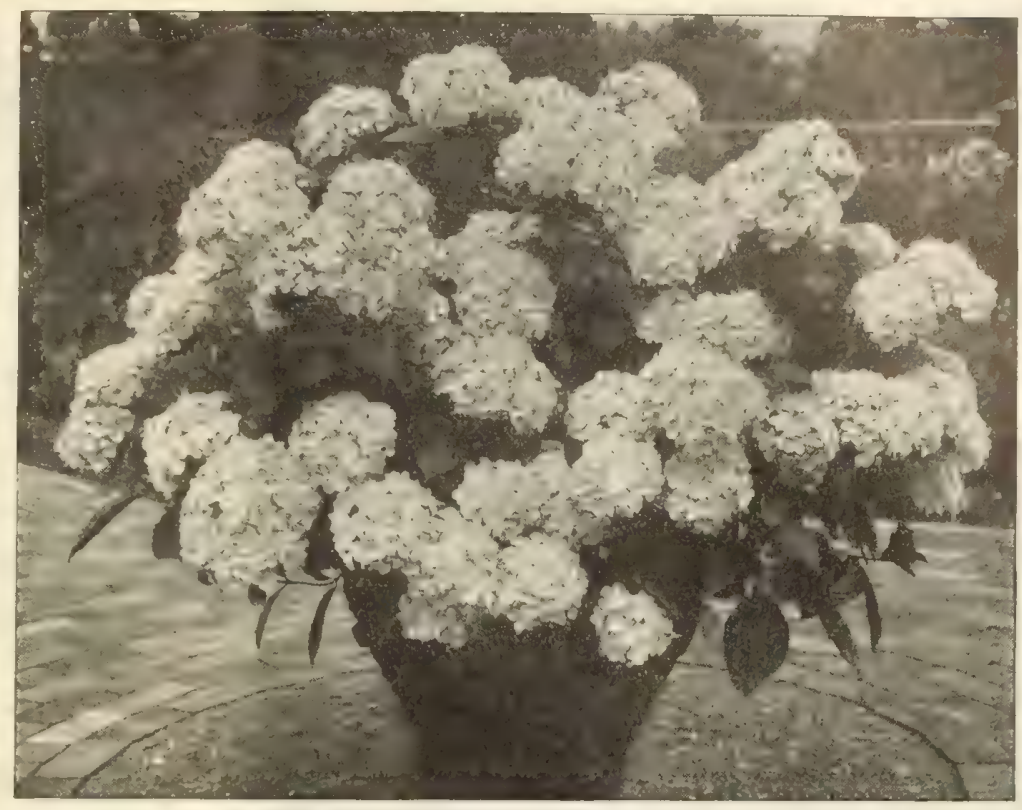

Botaniste Peltereau. Enormous flowers of a pretty mauve rose. $2^{1 / 4}$-inch pots, $\$ 0.75$ per doz.; $\$ 5.00$ per 100

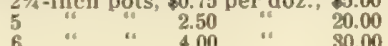

Bouquet Rose. Large trusses of rosy amber turning to bright pink; a favorite in the New York market.

$2 \%$-inch pots, 81.50 per doz.; $\$ 10.00$ per 100.

Dentelle. Entirely distinct, deeply fringed flower of a creamy white color; it is not suited for forcing, but for Decoration Day and later flowering it is very valuable.

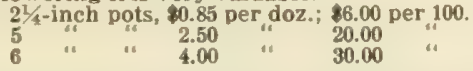

Fraicheur. Very large, regularly shaped flowers, white, delicately suffused with rose, very free flowering

$$
\begin{aligned}
& 2 \frac{1}{4} \text {-inch pots, } \$ 0.85 \text { per doz.; } \$ 6.00 \text { per } 100
\end{aligned}
$$

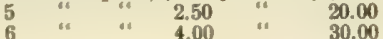

General de Vibraye. A favorite wherever seen; very large heads of bright rose colored flowers, a splendid early forcing variety. $2 \%$-inch pots, $\$ 1.50$ per doz.; $\$ 10.00$ per 100 .

La Lorraine. Very large flowers, pale rose, turning to bright pink; has become a general favorite during the past two years. $21 / 4$-inch pots, $\$ 1.50$ per doz.; $\$ 10.00$ per 100 .

Mme. A. Riverain. Superb bright rose color; very vigorous and floriferous. One of the most successful growers in the U. S. considers this one of the very best yet introduced.

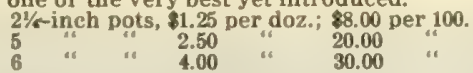

Mme. E. Moullere. This is the favorite white variety in the New York market, very free flowering, of good size and form. Awarded silver medal at the National Flower Show at Boston. A great favorite with English growers, one London grower handling over 30,000 of this variety alone. $2 \%$-inch pots, $\$ 1.50$ per doz.; 810.00 per 100 .

Mme. Maurice Hamar. Described by the introducer as a delicate flesh rose-color. In our soil it has been a most beautiful deep blue, and has been admired; a vigorous grower; the individual flowers as well as the trusses being of immense size. One of the flowers as well as the tr

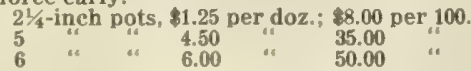

Mme. Raymond. Large trusses of perfectly round flowers of a transparent white, passing to a tender rose. In competition with transparent white, passing to a tender rose. In competition with all the other white varieties was awarded a cert
ing of the National Association of Gardeners.

$$
\begin{aligned}
& 21 / 4 \text {-inch pots, } \$ 1.25 \text { per doz.; } \$ 8.00 \text { per } 100 \\
& \begin{array}{lll}
21 / 4 \text {-inch pots, } & \$ 1.25 \\
5 & \text { " } & 4.50 \\
6 & \text { " } & 6.00
\end{array}
\end{aligned}
$$

Mile. Agnes Barillet. A splendid white; a grand variety for a 5or 6-inch pot plant. From our own observation we are inclined to consider this the best of all the whites.

$$
\begin{aligned}
& 2_{5}^{1 / 4-i n c h} \text { pots, } \$ 1.25 \text { per doz.; } \$ 8.00 \text { per } 100
\end{aligned}
$$

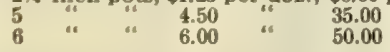

Mile. Renee Gaillard. Very large panicles of milky white, irregularly dentated flowers. One of the best growers says that this should have been awarded the Silver Medal given to Mme. Emile Mouillere last year as the best white. $2 \frac{1}{4}$-inch pots, $\$ 1.25$ per doz. $\$ 8.00$ per 100

SPECIMEN HYDRANGEA

Mlle. de Tremault. As the result of our own trials we are convinced that this variety is the best very large flowered white yet introduced. As free flowering as any, of splendid erect habit producing flower heads as large as the old popular Otaksa.

$$
21 / \frac{1}{6} \text {-inch pots, } \$ 1.25 \text { per doz.: } \$ 8.00 \text { per } 100 \text {. }
$$

Mousseline. A beautiful mauve-rose with cream-colored centre the flower heads are large and held erect; a fine acquisition.

$$
2 \frac{1 / 4}{4} \text {-inch pots, } \$ 1.25 \text { per doz.; } \$ 8.00 \text { per } 100 \text {. }
$$

Mont Rose. Immense panicles of clear flesh-rose, entirely distinct, one of the best very early flowering varieties.

$21 / 4$-inch pots, $\$ 1.50$ per doz.; $\$ 10.00$ per 100 .

Mons. G. Renault. Very large flowers of a bright rose with carmine reflex; very free and easily forced.

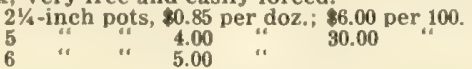

Ornament. Large pretty mauve-pink flowers, very free flowering $2 \%$-inch pots, $\$ 0.85$ per doz.; $\$ 6.00$ per 100

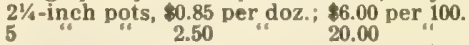

Ronsard. Flowers and trusses very large, of a beautiful rose tint. $2 \%$-inch pots, $\$ 0.85$ per doz. $\$ 6.00$ per 100

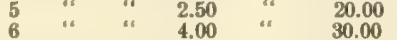

Radiant. Splendid rose-carmine, quite distinct from all others, an easy variety to force.

$2 \%$-inch pots, $\$ 1.25$ per doz; $\$ 8.00$ per 100

Souvenir de Mme. E. Chautard. One of the very best, of splendid erect habit, very robuste medium sized heads of bright rosecolored flowers; one of the very best of the Bouquet Rose type.

$$
\begin{aligned}
& 2 \% \text {-inch pots, } \$ 1.25 \text { per doz.; } \$ 8.00 \text { per } 100
\end{aligned}
$$

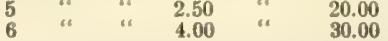

Senateur Henri David. Another splendid rose-colored variety. with red reflections, flowers produced in immense large heads: on the style of La Lorraine, but an earlier bloomer. $2 \%$-inch pots, $\$ 1.50$ per doz.; $\$ 10.00$ per 100 .

\section{Collections of New Hydrangeas} One each of the 22 varieties, $21 / 4$-inch pots $\cdots \cdots \cdots$
"

\section{Hydrangea Otaksa.}

Strong Dormant Plants Prepared for Late Flowering.

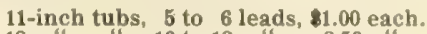

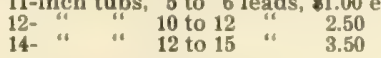

Also $2 \frac{1}{4}$-inch pots, $\$ 4.00$ per $100 ; \$ 35.00$ per 1000 .

\section{Hydrangea Souvenir de Claire.}

A splendid lot of very strong 8 -inch tubs of this free-flowering desirable pink variety, with from four to six leads. $60 \mathrm{cts}$, each. Also $2 \frac{1 / 4}{-1}$ inch pots. $\$ 4.00$ per $100 ; \$ 35.00$ per 1000 . 


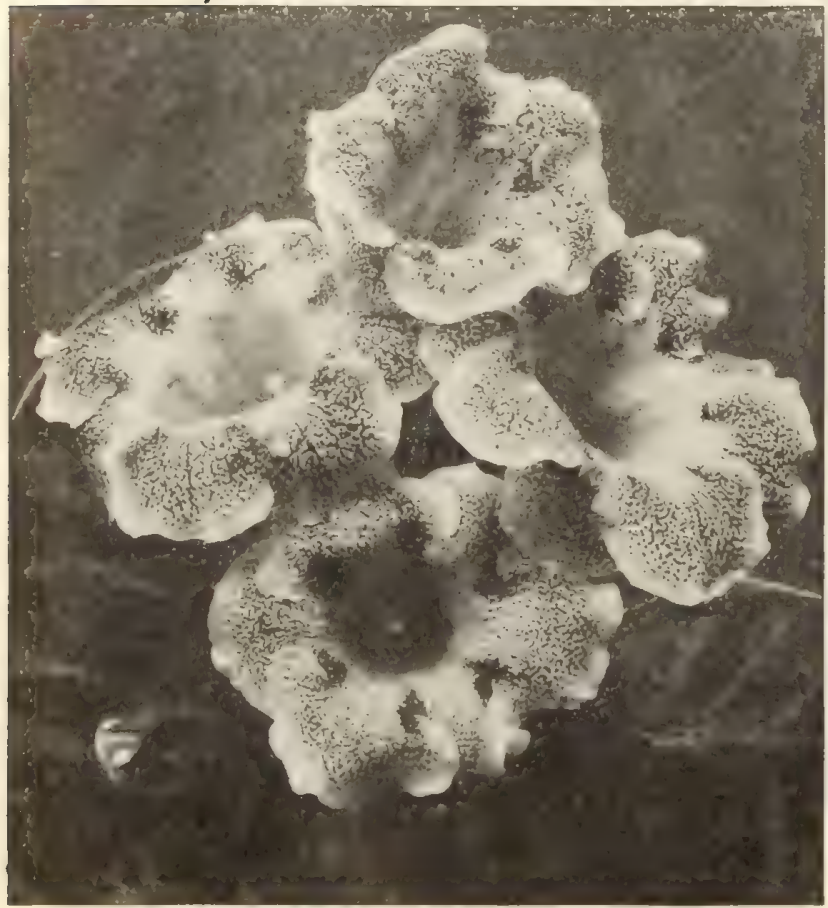

DREER'S SUPERB GLOXINIAS

\section{GERANIUMS}

\section{Best Newer Single Geraniums.}

Charles Guerin. Large flowers in immense trusses of a salmon carmine with white eye.

Dlamant. Flowers white, bordered with mauve, distinct and pretty. Frederlc Plessis. Flower and truss large, having a carmine border shading to a large white centre.

Kleios, A brilliant crimson, shading to violet at centre, with white eye.

Plerre Valdagne. Large flowers of a bright clear carmine-lake. Sacha Guitry. Brilliant scarlet-orange flowers. $15 \mathrm{cts}$. each; 81.50 per doz.: set of 6 for $75 \mathrm{cts}$.

\section{Best Newer Double Geraniums.}

Agathos. Immense trusses of deep carmine-colored flowers.

Baronne de Lonqueil. Large semi-doubleflowers of a Tyrianrose color, white eye

Clement Marot. Gooseberry-red with large white eye.

Marquise d' Abadie. Large rose-pink flowers with white eye. Mme. Paola Radaelli. Large creamy white, quite distinct.

President Luizet. One of the prettiest, a light, rich crimson-red with the base of the petals orange.

$15 \mathrm{cts}$. each; 81.50 per doz.; set of 6 varieties for $75 \mathrm{cts}$.

\section{Dreer's Superb Gloxinias.}

Our strain of these is the finest procurable; the bulbs are well matured and of larre size.

We offer either separate colors, as blue, red, white, red with white edge, blue with white edge, or in choice mixture, at $60 \mathrm{cts}$ per doz.; $\$ 3.50$ per $100 ; \$ 30.00$ per 1000

\section{New Emperor Gloxinia.}

Gloxinia Hybrida Imperialis.

A new hybrid strain which has been produced by crossing Sin ningia Regina Hybrida with the choicest strains of Gloxinias, re sulting in a plant which not only embraces all of the rich and varied colors of the Gloxinia but in which the foliage also is distinct and very ornamental the leaves being of a reddish brown or bronz color with strongly projecting white veins, while the flowers are color with strongly projecting white veins, white the flowers are

Strong bulbs in choice mixed varieties. $85 \mathrm{cts}$. Der doz.; $\$ 6.00$ per 100 .

\section{Ismene Calathina.}

Peruvian Daffodil

A beautiful summer flowering bulb, producing freely large Amaryllis-like pure white fragrant blossoms. A useful cut flower. Strong flowering bulbs, 85 cts. per doz.; $\$ 6.00$ per 100 .

\section{Pandanus Pacificus.}

A rare and beautiful species with broad massive dark green foliage. 4 -inch pots, $35 \mathrm{cts}$. each; 5 -inch pots, $75 \mathrm{cts}$, each

\section{Pandanus Veitchi.}

A grand lot of well-colored, perfect plants. 6-inch pots, fine specimens ..... 81.00 each

8. " $"$ "

Pandanus Utilis.

2-inch pots, \$1.00 per doz.; \$7.00 per 100

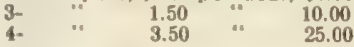

\section{Pelargoniums.}

Crimson King An intense rich crimson.

Duke of Cornwall. Reddish crimson, bordered light salmon.

Linda. Salmon-feathered and blotched maroon.

Mme. Thibaut. White-biotched crimson-maroon.

Mrs. R. Sandiford. Pure, glistening snow-white.

Sandiford's Best. Pink-bordered pure white and white throat.

3 -inch pots, $\$ 1.50$ per doz.; $\$ 10.00$ per 100

\section{New Everblooming Pelargonium, "Easter Greeting."}

This variety is remarkable for its early and free-flowering habit, and while its principal crop of flowers is produced in early spring. it is the first variety introduced which, in a favorable season. continues to bloom throughout the summer and fall months. Its flowers are of large size, of a bright amaranth-red, each petal marked with a large black blotch. $15 \mathrm{cts}$. each: 81.50 per doz.

\section{Pennisetum (Fountain Grass)}

The Pennisetums are now largely used as borders to beds of Cannas. Caladium Esculentum and other tall-growing plants and are becoming more popular each season.

Cupreum. A cross between the tine-leaved $P$. Rueppelianum and the red-leaved $P$. Macrophullum Atrosanguineum, and combines the good points of both of its parents. It has dark, coppery bronze foliage; the plumes are of a tawny crimson color. It grows 8 to $3 \frac{1}{3}$ feet high. A distinct and valuable addition to our list of tender grasses.

Young plants ready April 15th; $\$ 1.25$ per doz; $\$ 8.00$ per 100.

Macrophyllum Atrosanguineum (Crimson Fountain Grass). Foli age of a pleasing, dark, metallic, coppery bronze, Ready Apri 15 th; 81.00 per doz.; $\$ 7.00$ per 100

Rueppellanum (Purple Fountain Grass). A beautiful variety. growing about $2 \frac{1}{2}$ feet high; graceful green foliage and purplish plumes, $2 \frac{1}{2}$-inch pots, ready May ist. 75 cts. per doz: 85.00 per 100 .

Japonicum. (New Hardy Fountain Grass). We offer this splendid addition with other hardy plants see page 44 .

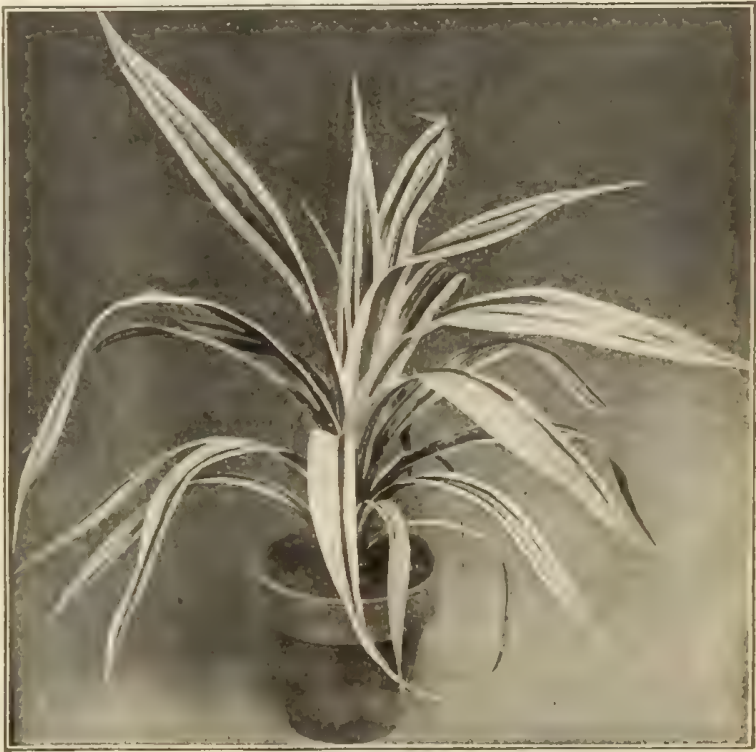

PANDANUS VEITCH 


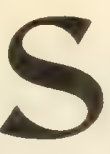

Areca Lutescens.

A splendid lot of well-shaped plants, of good color.

$2 \frac{1}{4}$-inch pots, 2 plants in a pot, 85 ets. per doz.; $\$ 6.00$ per 100 ; $\$ 50.00$ per 1000

4 -inch pots, 3 plants in a pot, 15 to 18 inches high, $\$ 3.50$ per doz.: $\$ 25.00$ per 100.

5 -inch pots, 3 plants in a pot, 18 to 24 inches high, $\$ 6.00$ per doz. 850.00 per 100

6-inch pots, 3 plants in a pot, 24 to 28 inches high, 11.00 each.

7 -inch pots, 3 plants in a pot, 36 inches high, $\$ 2.00$ each.

8 -inch tubs, 3 plants in a tub, 42 inches high, $\$ 3.00$ each.

10 -inch tubs, bushy plants, 48 inches high, $\$ 5.00$ each.

\section{Areca Verschafeltii.}

A pretty Palm, finely feathered in the style of Areca Lutescens, the foliage is a dark olive-green color with a creamywhite mid-rib.

$2 \%$-inch pots, $\$ 1.50$ per doz.; $\$ 10.00$ per 100

4 -inch pots, $\$ 5.00$ per doz.; $\$ 40.00$ per 100 .

\section{Bactris Major.}

A rare and unique $\mathrm{Palm}$, interesting on account of the long spines with which both surfaces of the leaf are covered.

4-inch pots, 75 ets. each.

\section{Caryota Blancoii.}

A rare variety of the Fish-tail Palm.

3 -inch pots, $\$ 1.50$ per doz:; $\$ 10.00$ per 100 .

\section{Caryota Urens.}

$2 \frac{1}{4}$-inch pots, $\$ 1.25$ per doz.; $\$ 8.00$ per 100 .

\section{Chamadora Elegans.}

3-inch pots, $\$ 1.50$ per doz.; $\$ 10.00$ per 100 .

\section{Cocos Weddeliana.}

We have nearly an acre of glass devoted to this most graceful of all Palms. Splendid, thrifty stock, of rich dark color.

2 -inch pots, 5 to 6 inches high, $\$ 1.50$ per doz $; 10.00$ per 100 5 to 24 splendid plants, 75 cts. each. 7
9 $\quad 34$ to 36 " " $\quad$ ". grand specimens, $\$ 2.50$ each.

\section{Deckeria Nobilis.}

A rare collection Palm for the stove. 4 -inch pots, $\$ 2.00$ each.

Damonorops Palembanicus (Calamus).

Nice plants in 4 -inch pots, $\$ 2.00$ each.

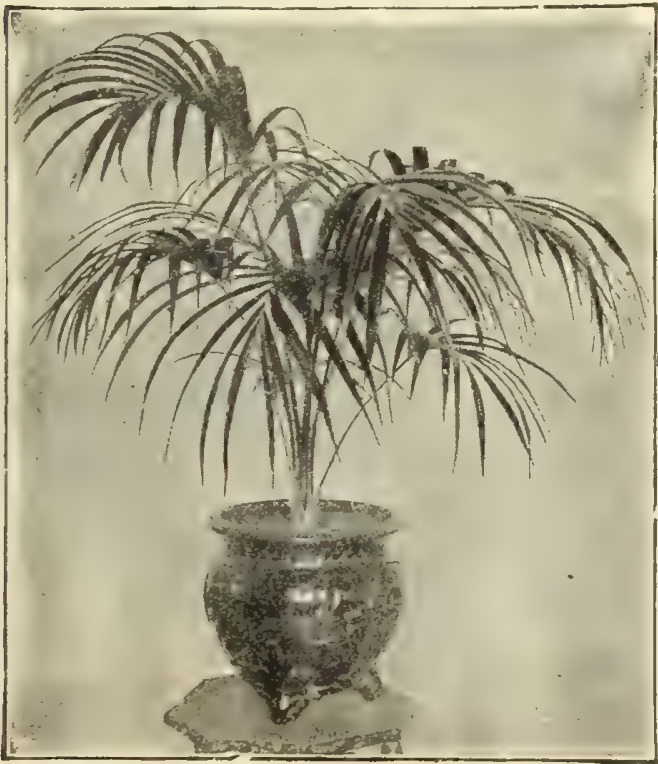

KENTIA BELMOREANA

\section{Our Leading Specialty}

We again call special attention to our stock of $\mathrm{Palms}$, which is the largest and most complete in the country, especially in the varieties and sizes used in the general florists' trade, our stock of Kentias alone occupying over two acres of glass, and all other popular varieties being on hand in proportionate quantities.

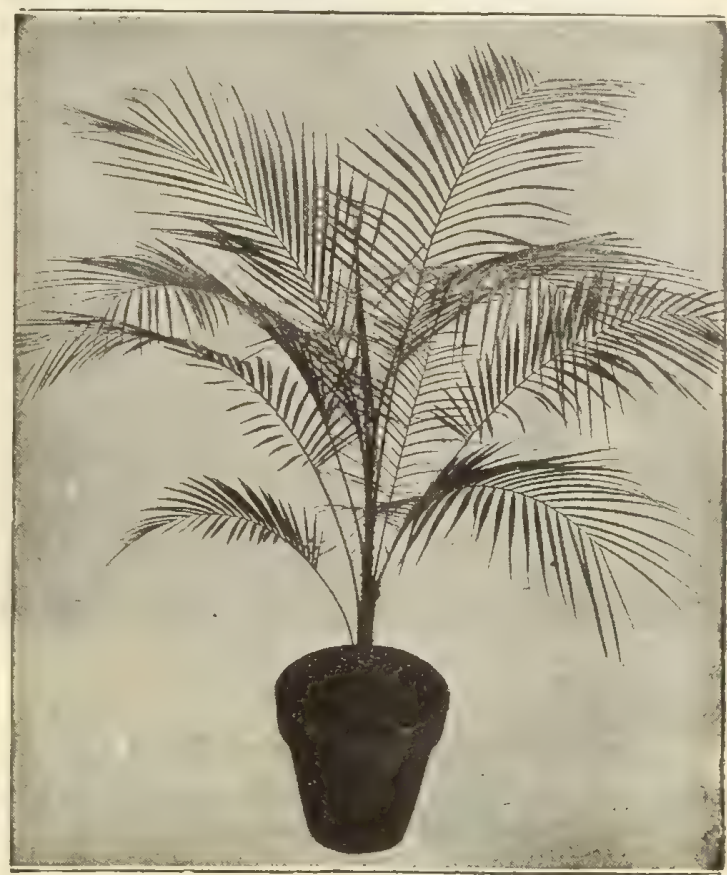

COCOS WEDDELIANA

Elaeis Guineensis.

One of the most attractive Palms where a high temperature can be maintained.

4-inch pots, 50 cts. each.

5 -inch pots, $75 \mathrm{cts}$. each.

\section{Kentia MacArthuri.}

5-inch pots, 24 inches high, 75 cts, each.

\section{Kentia Praemorsa.}

A new variety of Kentia with foliage somewhat on the style of a Caryota or Wallichea. Strong 4-inch pots, 50 cts, each.

\section{Kentia Belmoreana.}

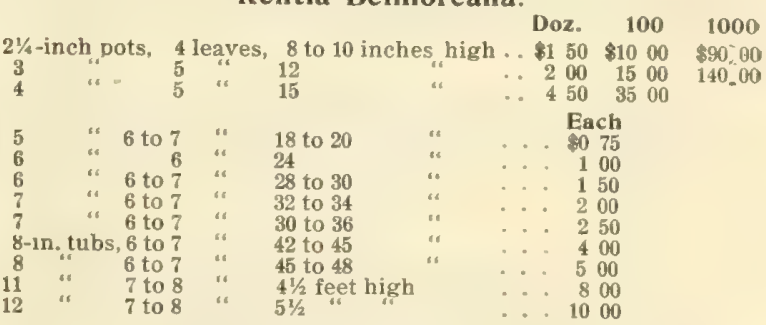

\section{Kentia Forsteriana.}

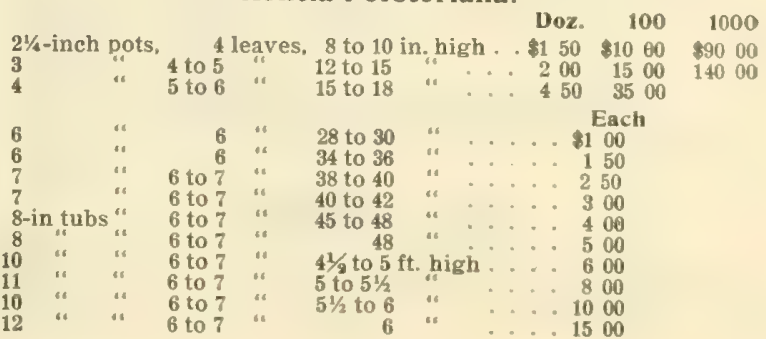




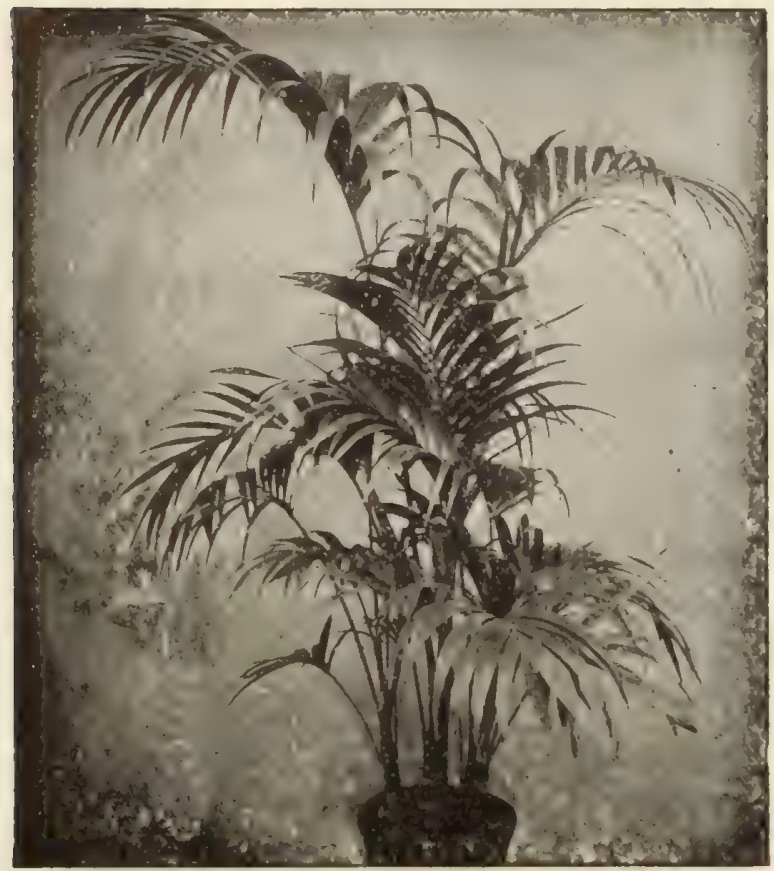

A MADE-UP PLANT OF KENTIA

\section{Kentia Forsteriana-Made-up Plants.} 5 -inch pots, 4 plants in a pot, 18 to 20 inches high .... 2075 7 ". tubs, 3 plants in a tub, 36 inches high .... 250

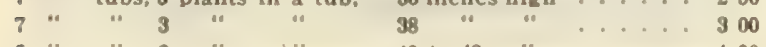

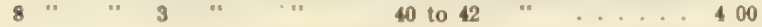

8 " $" 3$ " 42 to 45 ". $4 . .500$

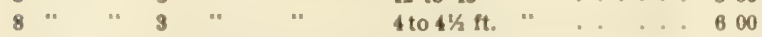

8 " 3 " 4 " 4 to $5 \mathrm{ft}$ " .... 800

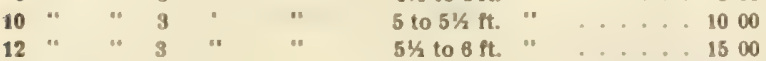

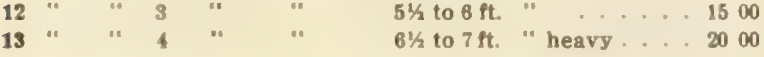

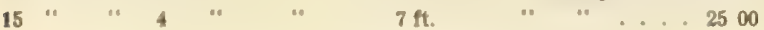

\section{Kentia Sanderiana.}

Comparatively new and one of the most graceful and hardiest of the Kentias.

Bushy made-up plants in 4-inch pots, 12 to 15 inches high, 75 cts. each

\section{Kentia Wendlandi.}

3-inch pots, $\$ 2.00$ per doz, 815.00 per 100

5 -inch pots, 24 inches high, 81.25 each.

\section{Latania Borbonica.}

$2 \frac{1}{4}$-inch pots, 75 cts. per doz.; $\$ 5.00$ per $100 ; 840.00$ per 1000 .

3 " $\$ 1.25$ " 10.00 " 90.00

\begin{abstract}
2.50
\end{abstract}
20.00

\section{Livistona Rotundifolia.}

We offer a fine lot of this desirable miniature Fan-Palm.

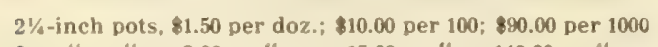

$\begin{array}{lllllllll}3 & \text { " } & \text { " } & 2.00 & \text { " } & 15.00 & \text { " } & 140.00 & \text { " } \\ 4 & \text { " } & & 3.50 & \text { " } & 25.00 & \text { " } & 240.00 & \text { " }\end{array}$

\section{Nephrosperma Van Houtteanum.}

A rare stove-palm. 31/2-inch pots, $\$ 2.00$ each.

\section{Phoenix Canariensis.}

9-inch tubs, 48 to 50 inches high, bushy plants 10 - " 64 to 60 " " " " " ". 600 11 - " " 60 " 60 " heavy " .... 750

\section{Phœnix Roebelenii.}

Unquestionably one of the prettiest and most graceful Palms grown, which quickly made a place for itself among the popular standard varieties, particularly so for apartment decorations. We have a splendid stock, and offer:

4 -inch pots, nicely characterized plants, $\$ 6.00$ per doz.; $\$ 50.00$ per 100

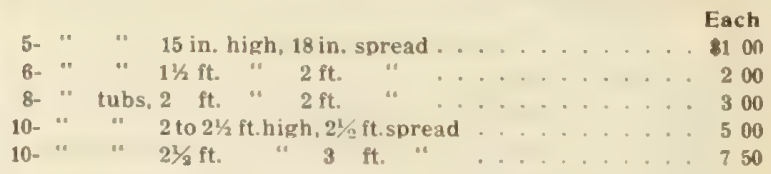

\section{Phonix Reclinata.}

3-inch pots, 1.25 per doz., $\$ 8.00$ per 100

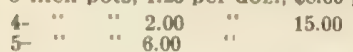

\section{Pritchardia Pacifica}

Splendid plants of this fine hot-house Palm.

4 -inch pots, 35 cts, each.

5 -inch pots, $\$ 1.00$ each.

\section{Ptychosperma Alexandrea.}

3-inch pots, $\$ 1.50$ per doz.; $\$ 10.00$ per 100

\section{Rhapis Flabelliformis.}

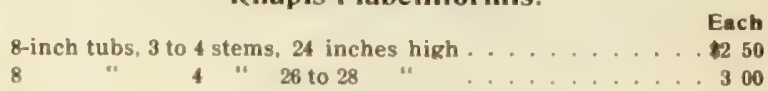

\section{Roscheria Melanochates.}

A rare hot-house Palm. making a solendid exhibition plant. Strong 4-inch pots, $\$ 1.50$ each.

\section{Stevensonia Grandifolia.}

It is only at rare intervals that we are in position to offer this interesting stove palm. 5-inch pots, 83.00 each.

\section{Thrinax Parviflora.}

A pretty species in which the palmate leaves are narrowly divided, very graceful.

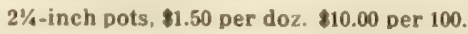

3 " " 2.00 " 15.00 "

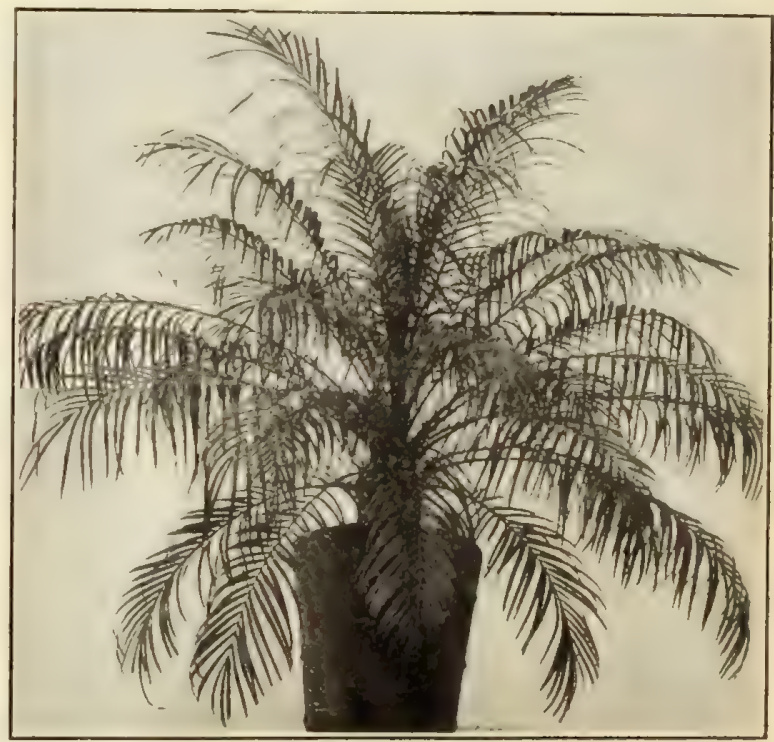

PHCENIX ROEBELENII 


\section{Miscellaneous Garden, Greenhouse and Bedding Plants}

ABUTILONS. 6 distinct choice varieties ACALYPHA. Macafeana. 21/4-inch pots

ABUTLONS. 6 distinct choice varieties
ACALYPHA. Macafeana. $2 \frac{1}{4}$-inch pots
Macafeana, 3 inch pots
ACHYRANTHES. Acuminata. Large bronzy red foliage

Brilliantissima. Rich crimson foliage
Emersoni. Deep red, narrow leaves.

AESCHYNANTHUS. Orandiflora. 3-inch pots. AGLAONEMA. Costata Variegata. $40 \mathrm{cts}$. each Marantafolium Maculatum. $30 \mathrm{cts}$. each

AGAPANTHUS. Umbellatus. Blue. Strong plants Umbellatus Albus. White. Strung plants

AGERATUM. Inimitable, Mont Blanc, Princess Pauline, Stella Gurney and Tip=Top

ALAMANDA. Hendersoni. 3-inch pots

Williamsit. $2 \%$-inch pots

A Lovsia. Citriodora. $2 \frac{31 / 4}{3-i n c h}$ pots Citriodora. 3-inch pots

ALTERNANTHERA. Aurea Nana. Ready in May $\$ 35.00$ per 1000

Brilliantissima. Ready in May. $\$ 35.00$ per 1000 Jewel. Ready in May. \$35.00 per 1000 Rosea Nana. Ready in May. $\$ 35.00$ per 1000 Versicolor. Ready in May

ARALIA CHABRIERI. $75 \mathrm{cts}$. each Montrosa. $35 \mathrm{cts}$. each

BEGONIA. Alba Picta

Argentea Guttata

Feastii

Haageana

Saunders

BOUGAINVILLEA. Sanderiana. 3-inch pots W. K. Harris

Per doz. Per 100

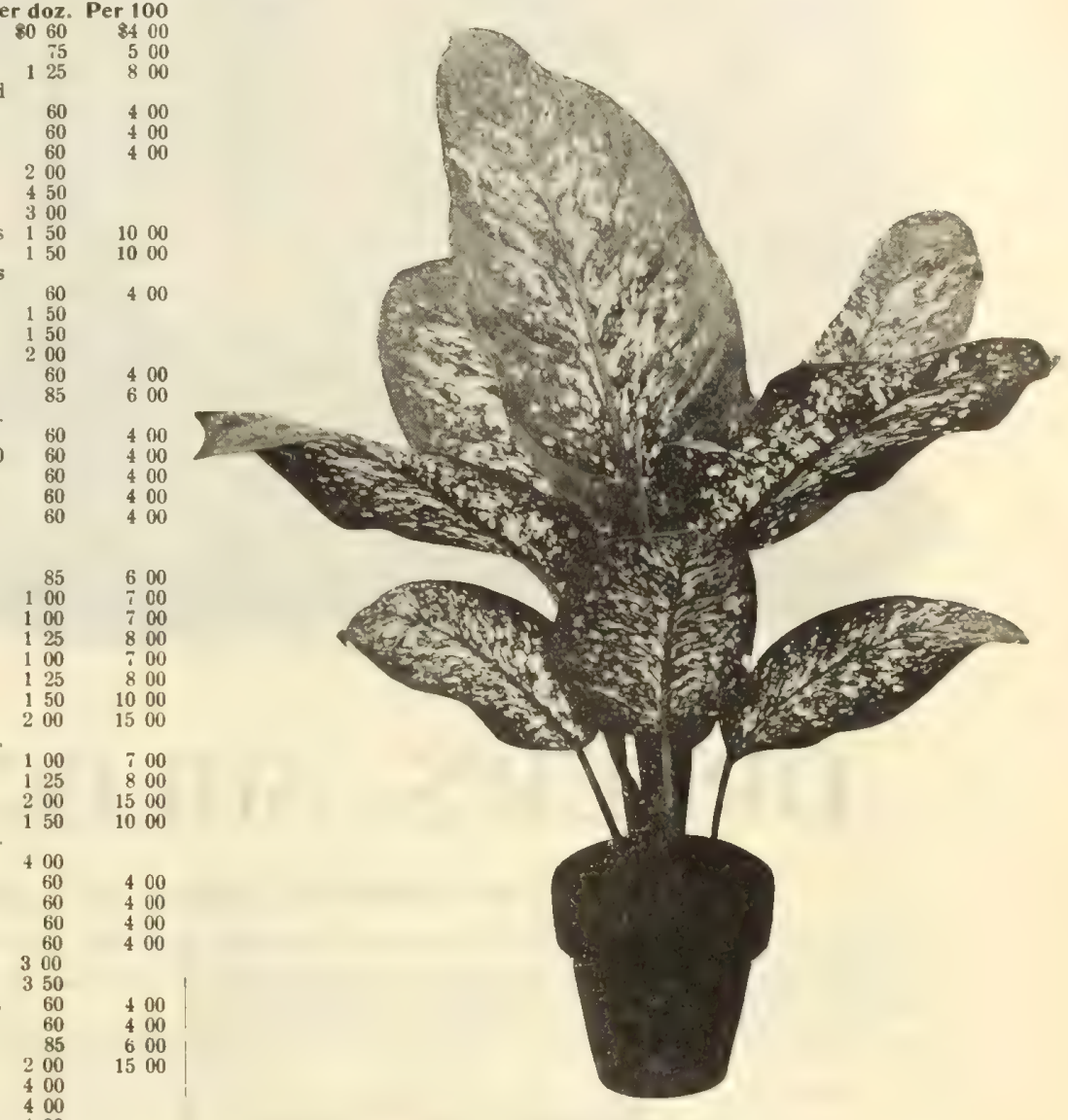

Tarqui (Night-blooming Jessamine)

21/4-inch pots . Balfouri. 3-inch pots
CLERODENDRON. Bals

Balfouri. 4-inch pots
Falax. 3-inch pots

Cl.IVIA (Jmantophyllum) . Miniatum. Strong, 6 inch pots. $40 \mathrm{cts}$. each

COLEUS. Verschafelti. $2^{1 / 4}$-inch pots

Queen Victoria. 2\%-inch pots

Golden Bedder. $2 \frac{1}{4}$-inch pots

12 choice varieties. $2 \frac{1}{4}-$ inch pots.

COSTUS. Zebrinus. $35 \mathrm{cts}$. each

CUPHEA. Platycentra (Cigar Plant). $2 \frac{1}{4}$-inch pot

CYPERUS. Aiterntfolius. $2 \frac{1}{4}$-inch pots Alternifolius, 3-inch pots

DIEFFENBACHIA. Baraquiniana. $40 \mathrm{cts}$ each Bausel. $40 \mathrm{cts}$, each .

Bowmannl. $40 \mathrm{cts}$. each

Eburnea. $40 \mathrm{cts}$. each

Imperialis. $40 \mathrm{cts}$. each

Jenmani. $40 \mathrm{cts}$. each

Jenmani. $40 \mathrm{cts}$. each
Leopoldi. $40 \mathrm{cts}$. each

Leopoldi. $40 \mathrm{cts}$. each

Magnifica, $40 \mathrm{cts}$, each
Memora Corsi. $40 \mathrm{cts}$. each

Picta. $40 \mathrm{cts}$. each

Rex. 40 cts. each

Splendens. $40 \mathrm{cts}$. each

EUCHARIS. Amazonica

EURYA. Latifolia Variegata

FARFUGIUM. Grande. 4-inch pots.

FICUS. Pandurata. 2 feet high. $\$ 2.00$ each

3 feet high. $\$ 3.00$ each
4 feet high. $\$ 4.00$ each..
Large Specimen Plants. $\$ 5.00$

Altissima. 3-inch pots

i. $\quad 3$ feet high. $\$ 3.00$ each arge Specimen Plants. $\$ 5.00$

Repens. 3-inch pots

Lutescens. 3-inch pots
Utilis. New

Wendlandi. 4 -inch pots

FUCHSIAS, 10 choice double and single varieties

GARDENIA. Florida, 3-inch pots

HELIOTROPES. 6 fine sorts. 3-inch pots .

HIBISCUS. Sinensis. 5 distinct varieties

IPOMEA. Noctiflora (White Moon-flower)

Learii (Blue Dawn-flower)
Paniculata or Mexicana (Rosy Dawn-flower

ISOLEPIS. Gracills. 21/4-inch pots

JASMINUM. Grandiflorum. 3 -inch pots

LAPAGERIA. Rosea and Alba. \$1.25 each

LANTANAS. 8 choice varieties. $2-1 / 4$ inch pots

MANETTIA. Bicolor. $2-\frac{1}{4} / 4$ inch pots

MUSA. Ensete. 4-inch pots. 30 cts. each

Ensete. 6-inch pots. 75 cts. each

NEPHTHYTIS. Picturata. $75 \mathrm{cts}$, each

NEPENTHES (Pitcher Plants) 4 inch pots

Domini, Sedeni. $\$ 1.25$ each

Henryana, Phyllamphora, Pattersoni, Splen

dida. $\$ 1.50$ each

Cortii, Hookeriana, and intermedia. $\$ 2.00$ each

DIEFFENBACHIA

OLEA. Fragrans. 4-inch pots. $35 \mathrm{cts}$. each

Per doz. Per 100

Fragrans. 5-inch pots. $75 \mathrm{cts}$, each

PANAX. Balfouri. 35 cents each

Gracillima. 35 cts. each

Monstrosum Aureum. $35 \mathrm{cts}$, each

1500

1500

PASSIFlORA. Pfordti, 21/4-inch pots

Pfordti, 4-inch pot

Constance Elliot. $2 \frac{1}{4}$-inch pots

N. Spectabilts. 4 inch pots 75

Pertusum 4 cts, each . ...... 750

PHYGELIUS. Capensis (Cape Fuchsia) 3 inch pots 150 PHYLLOT AENIUM. Lindeni Magnificum. $75 \mathrm{cts}$

1000

1000

Plumbago. Capensis. Blue.

Capensis. White

500

1200

500

700

400

400

1200
500

500
800

400

500

300

900

PHOTOS. Argyrea. 3 inch pots. $20 \mathrm{cts}$ each 125

PUNICA. Granatum Lagrelil (Pomegranate). 4

RHYCHOS pots. . 300 Remoinei Multiflora. 21/4 inch pots . 75 REVIERA. Zeylanica. 21/4 inch pots

MILAX. 21/4 inch pots

New Golden Leaved. 3 inch pots

SENECIO. Scandens (German or Parlor Ivy)

SOLANUM. Jasminoides Grandiflorum. 3 inch plots 100

SWAINSONA. Galegifolia. 21/4 inch pots. 75

STEPHANOTIS. Floribunda. 5 inch pots. 75 cts. each 6 inch pots, 100 each 1200

STIGMAPHYLLON. Cillatum (Brazilian Orchid

Vine)

THUNBERGIA. Laurifolia. 3 inch pots . 300

VERBENA. Tenera Mahonetti. (Star Verbena) 75

VINCA. Major Variegata. 4 inch pots 125

$\$ 60$

1000

$\begin{array}{rr}6 & 00 \\ 10 & 00\end{array}$

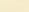

$\left(\frac{10}{2}\right.$

800

800
800

1500

600

500

300

$+00$

$\div 00$

500 


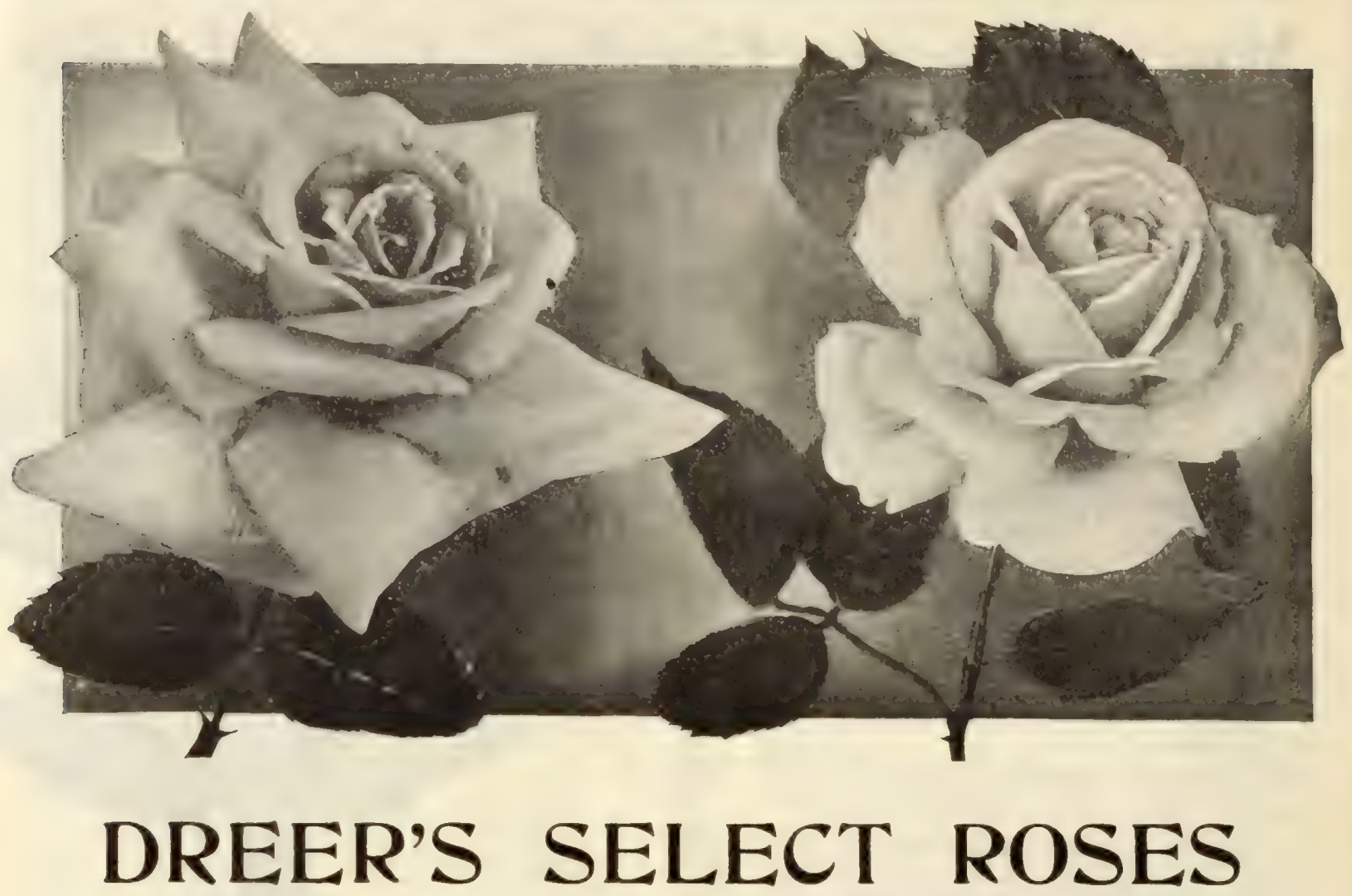

\section{Select Two-year-old stock for your Retail Trade}

The Roses which we here offer are, with lew exceptions, field grown stock either American grown or plants that have been i mported from England and Ireland.

These plants are all potted up during December and January, stored in cold houses, so that they break away naturally in spring, making this the best possible stock for selling to the retail customer.

The prices noted are for strong plants in 5 and 6 -inch pots according to the growth of the variety) for delivery during April and May, and while we will make shipments earlier if requested, we prefer to book orders for these months only.

\section{Hybrid-Tea Roses. Novelties and Recent Introductions.}

Arthur R. Goodwin British Queen

Cynthia Ford

Chateau de Clos Vougeot

Dorothy Page Roberts

Duchess of Sutheriand

Duchess of Wellington

Duchess of Westminster

Earl of Gosford

Ellzabeth Barnes

Edward Mawley

Eugene Boullet

Fernelhurst

Florence Haswell Veitch

George C. Waud
E. W. Cowan

Frances Charteris Seton

George Dickson

\begin{tabular}{|c|c|}
\hline Each & \\
\hline 250 & $\begin{array}{l}\text { Orace Molyneux. } \\
\text { Institateur Sirday }\end{array}$ \\
\hline & James Coey? \\
\hline 50 & John Cuff \\
\hline 50 & Jonkherr, J. L. Mock \\
\hline 200 & King George \\
\hline 50 & Lady Alice Staniey \\
\hline 100 & Lady Downe \\
\hline 200 & Lady Greenall. \\
\hline 50 & Lady Ursula \\
\hline 100 & Lieutenant Chaure \\
\hline & Mabel Drew \\
\hline 200 & Mary Countess of IIchester \\
\hline & May Kenyon Slaney \\
\hline 100 & Mme, Segond Weber \\
\hline 100 & Mlle. Marle Masquerand \\
\hline & $\begin{array}{l}\text { Margaret Molyneux . . } \\
\text { Mrs.Arthur Munt. }\end{array}$ \\
\hline
\end{tabular}

Hybrid-Tea Roses. Select Standard Sorts.

Antoine Rivoire.

Bessie Brown

Betty.

Belle Selbrecht

Caroline Testout

Countess of Gosford.

Dean Hole

Earl of Warwick

Ecarlate

Florence Pemberton

Franz Deegen

Farben Konigin

Gustav Grunerwald

Grace Darllng

General MacArthur

Grand Duke Adolphe de Luxemburg

G. Nabonnand

Gruss an Teplitz

Irish Brightness.

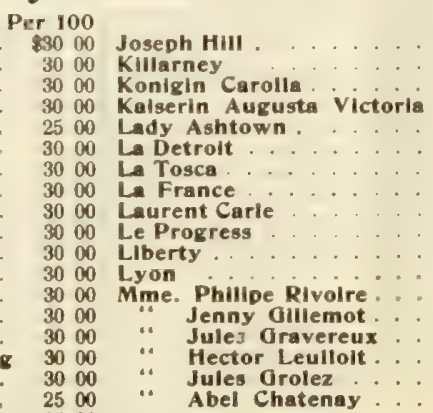

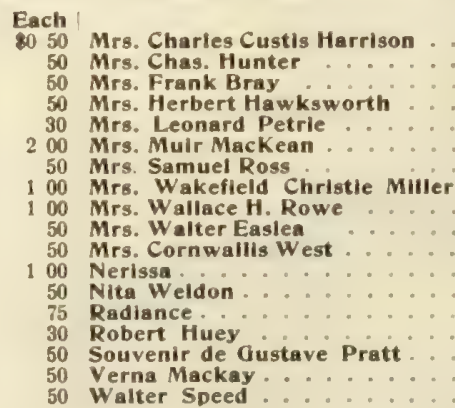

Each 2075 200 200 200 200

50

200
75

100

200
50

50

100

200

50

\section{Per 100}

83000 Mme. Ravary.

3000 Leon Pain

3000 Maurice de Luze

2500 Melanie Soupert

3000 Marquise de Sinety

3000 Mildred Grant

3000 Mons. Paul Lede

3000 Mrs. Aaron Ward

3000 My Maryland

3000 Pharlsaer

900 Prince de Bulgarle.

3000 Reine Marguerite de italle

3000 Richmond

3000 Simolicits

30 Souvenir de President Carnot... 3000

30 Viscountess Folkestone....... 3000

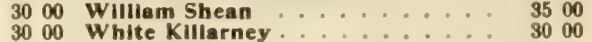

Per 100

83000
3000

3000

3000

3000

3000

3000

3500

3000

00

3000

00
00


Tea and other Everblooming Roses.

Corallina

Charlotte Klemm

Clothilde Soupert

Duchess de Brabant

Etolle de Lyon

Francisca Kruger

Hermosa

Hugo Roller

Harry Kirk

Lady Hillingdon

Maman Cochet Pink

". "White.

Marie Van Houtte

Mme. Joseph Schwartz

Molly Sharman Crawford

Miss Alice de Rothschild

Mrs. Hubert Taylor

Mrs. B. R. Cant

Perle des Jardins

Papa Gontier.

Queen's Scarlet, or Agrippina

Souvenir de Plerre Notting

Safrano

Catherine Gulliot

Souvenir de la Malmaison

William R. Smith

\section{Baby Rambler Roses.}

Annchen Muller. Pink Baby

Catharine Zlemet. White Baby

2000

2000

Jessie ...

2500

3500

Mme. Norbert Levavasseur. Crimson Baby . . . 2000
Mrs. Cutbush. Cherry-red Baby . . . . . 2000

Orleans (New) . ................... 2500

\section{Rugosa Roses.}

Two-year Old Plants.

Blanc Double de Coubert............. 2500

Nove Zembla ................... 2500

Rugosa Red ...................... 1800

White

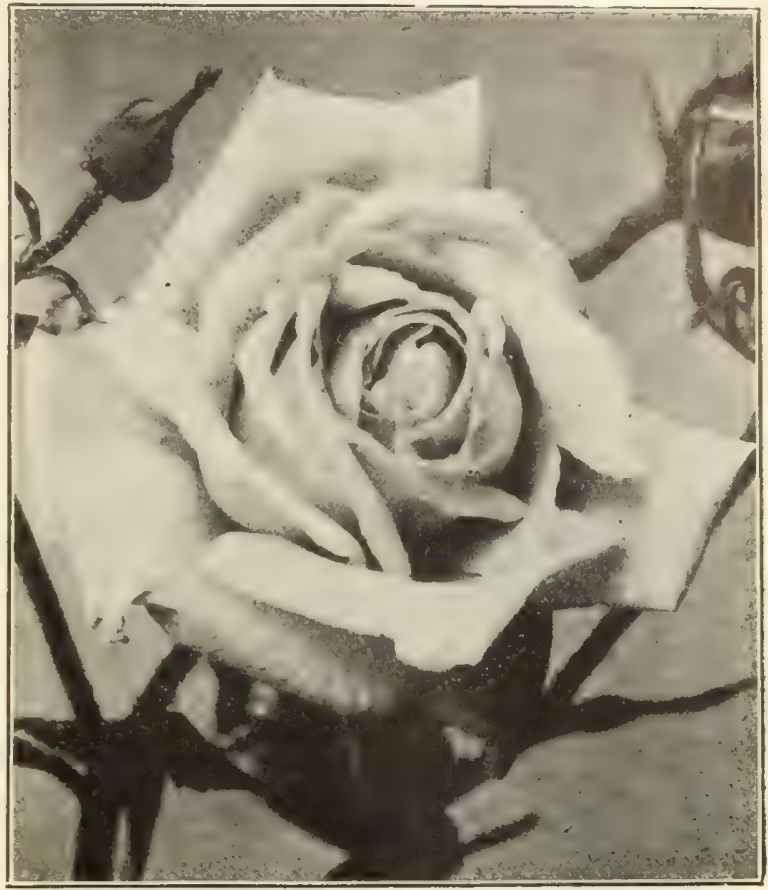

TRA ROSE, MAMAN COCHET

\section{Moss Roses.}

Strong, Two-year Old Plants.

Per 100

Blanche Moreau

$\$ 2500$

Comtesse de Muranaise ................ 2500

Crested Moss ...................... 2500

Crimson Globe ........... 2500

Gloire de Mosses ........ . . . . . . . . . . 2500

Princess Adelaide......... 2500

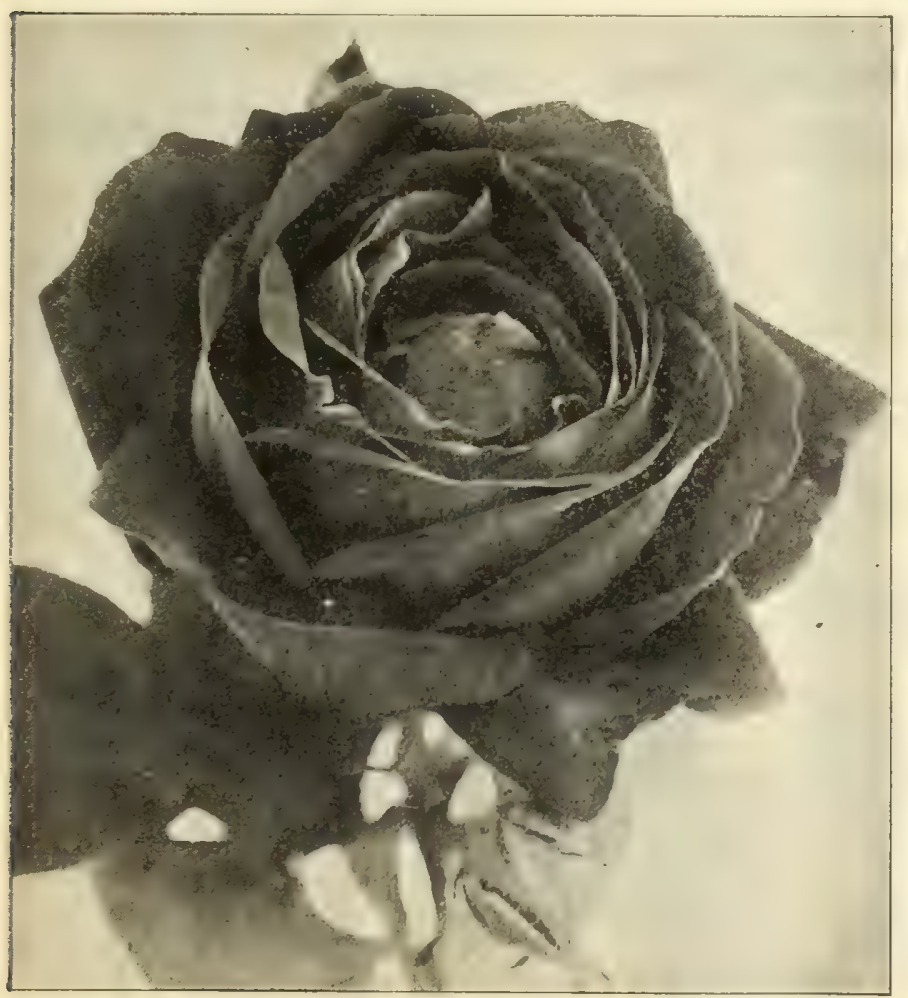

\section{Hybrid Perpetual Roses.}

Strong two-year=old plants.

Alfred Colomb

Anna de Diesbach

Alfred K. Williams

Amerlcan Beauty

Baroness Rothschlid

Baron de Bonstettin

Camille Bernardi

Captain Hay ward.

Clio

Charles Lefebvre

Duke of Edinburgh

Earl of Dufferin

Fisher Holmes.

Francols Michelon
Frau Karl Druschk!

Genera! Jacqueminot

George Arends (New)

Gloire de Chedanne Guinoisseau

Gloire de Margottin

Gloire Lyonnaise

Her Majesty

Hugh Dickson

Hugh Dickson

Jouis Van Houtte

Magna Charta.

Mrs. R. O. Sharman Crawford

Mrs. John Laing
Mabel Morrison

Mme. Victor Verdier

Mme. Gabrielle Luizet

Marie Baumann

Paul Neyron

President Kruger (New)

Prince Camilte de Rohan

Queen of Queens

Rodocanach

Tom Wood .

Victor Verdier.
Per 100

$\$ 2500$

2500

2500

3000 


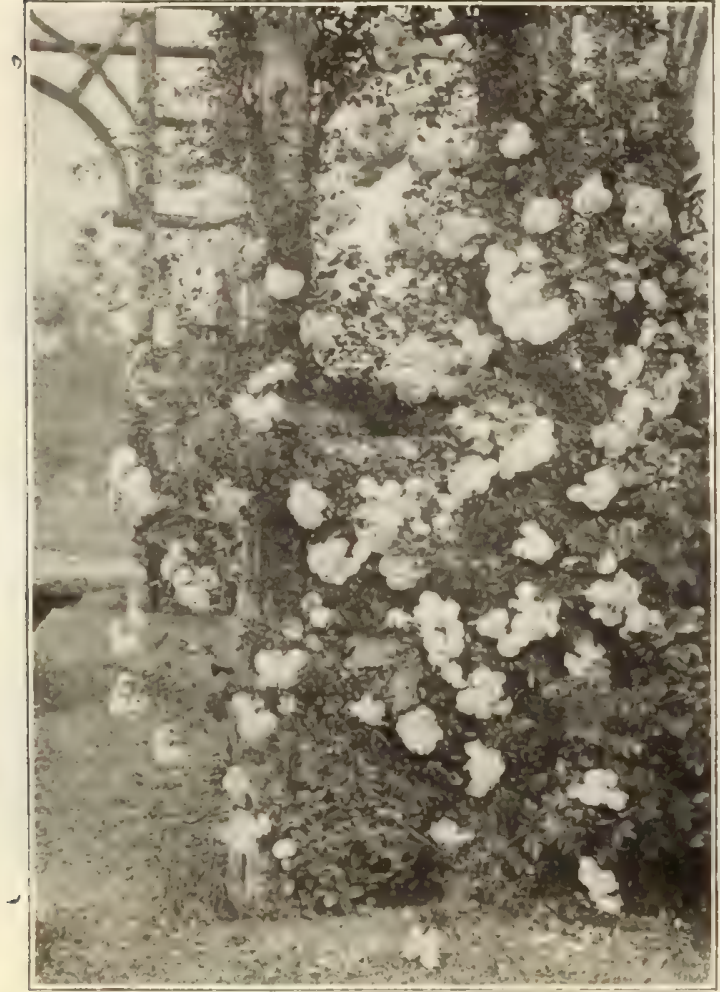

CLIMBING ROSE LADY GAY

\section{Austrian or Yellow Brier Roses.}

Two-year Old Plants.

Austrian Copper

Austrian Yellow

Harrison Yellow

Persian Yellow

\section{Pernetiana or Hybrid Austrian Briers.}

Jullet (New)

Soliel d' Or or Golden Sun

Per 100 $\$ 3500$

Rayon d' Or (New) 3000

\section{Sweet Brier Roses.}

Strong, Twoyear Old Plants.

Refulgence (New)

Anne of Gelerstein

Brenda.

Lord Penzance

Lady Penzance

Meg Meritlles

Common Sweet Briar or Egiantine

3500

3000

3000

3000

3000

3000

2000

Wichuraiana Roses.

Strong, Two-year Old Plants.

Wichuraiene "White

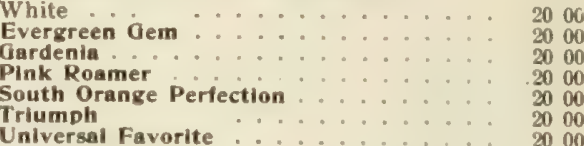

\section{Climbing and Rambler Roses.}

American Pllar

Baltimore Belle

Crimson Rambler

Christine Wright (New)

Climbing American Beauty (New)

Clothilde Soupert

i. Caroline Testout

Kaiserin Augusta victoria

Dorothy Perkins

Excelsa (New)

Flower of Fairlield

Gloire de Dijon.

Hlawatha

Lady Oay

Marechal Nell

Prairle Queen

Reine Marie Menriette

Tausendschon

Trier

White Dorothy

W. A. Richardson

White Banksla

Yellow Banksis

Yellow Rambler
00

2000

00

00

2000

\section{Choice Stock of Forcing Roses. 21/4-inch pots.}

We have made arrangements with one of the most successful growers of forcing Roses in the East to supply our trade with this class of stock, and our friends may rely on receiving plants of best quality only.

New Hybrid-Tea Milady.

A cross between J. B. Clark and Richmond. Of strong sturdy growth and excellent foliage, llowers large, double, opens perfectly at all seasons. In color similar to Richmond but richer in color in the bud, in form of flower and fragrance it resembles Gen. Jacqueminot; an excellent free-llowering forcing rose.

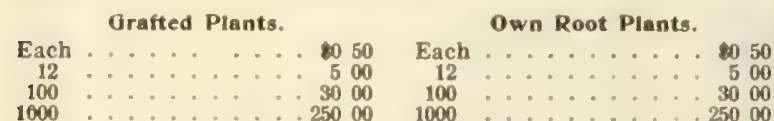

\section{Double White Killarney (Budlong).}

First disseminated last year. A pure white sport of the Waban strain of White Killarney, stronger in habit of growth than White Killarney with increased petalage and entirely free from pink even in warm weather.

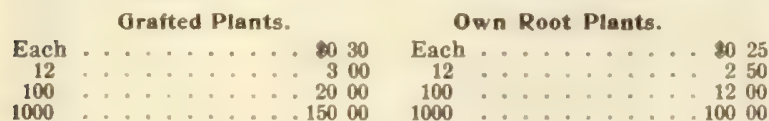

\section{Killarney Queen (Budlong)}

A cerise pink, sport of Killarney that for clearness and brightness of color has not been equalled.

Grafted Plants.

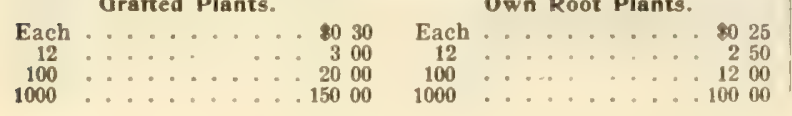

\section{Sunburst (Pernet Ducber)}

Orange-copper or golden-yellow, very intense and brilliant in color succceds best on own roots we therefore offer it in this shape only.

Own Root Plants. 30 cts. each; $\$ 3.00$ per doz.; $\$ 20.00$ per $100 ; \$ 150.00$ Der 1000.

\section{Lady Hillingdon.}

A very free flowering deep copper-yellow, long pointed but not heavy buds, an excellent variety for forcing.

$$
\text { Grafted Plants. }
$$

Each $\cdots \cdots$
12
100
1000

Miscellaneous Popular Forcing Roses.

\begin{tabular}{|c|c|c|c|c|c|c|}
\hline & \multicolumn{3}{|c|}{ Grafted Plants. } & \multicolumn{3}{|c|}{ Own Root Plents. } \\
\hline & $\begin{array}{l}\text { Per } \\
\text { Doz. }\end{array}$ & $\begin{array}{l}\text { Per } \\
100\end{array}$ & $\begin{array}{c}\text { Per } \\
1000\end{array}$ & $\begin{array}{l}\text { Per } \\
\text { Doz. }\end{array}$ & $\begin{array}{l}\text { Per } \\
100\end{array}$ & $\begin{array}{l}\text { Per } \\
1000\end{array}$ \\
\hline $\begin{array}{l}\text { Double Pink KIl- } \\
\text { larney }\end{array}$ & $\$ 200$ & $\$ 1500$ & $\$ 12000$ & $\$ 150$ & 8750 & 86000 \\
\hline $\begin{array}{l}\text { aiserin Augusta } \\
\text { Victoria }\end{array}$ & & & & & & \\
\hline Kilarney & 200 & 1500 & 1200 & 15 & 750 & 6000 \\
\hline $\begin{array}{l}\text { Mrs. Aaron Ward } \\
\text { Mrs. Taft (Antoine }\end{array}$ & 200 & 1500 & 12000 & 150 & 750 & 6000 \\
\hline Rivoire) . . & 200 & 1500 & 12000 & 150 & 750 & \\
\hline Melody. & No & grafted & plants. & 1. 50 & 750 & 8000 \\
\hline My Maryland & 200 & 1500 & 12000 & 150 & 1000 & 8000 \\
\hline Perle des Jardins & No & grafted & plants. & 150 & 750 & 6000 \\
\hline Radiance ... & 200 & 1500 & 12000 & 150 & & 6000 \\
\hline Richmond & 200 & 1500 & 12000 & 150 & 7 & 6000 \\
\hline hite KHIarney & & 1500 & 12000 & 150 & 750 & 60 \\
\hline
\end{tabular}

\section{Own Root Plants.}

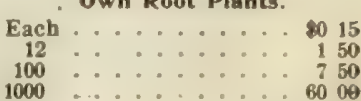




\section{HARDY PERENNIAL PLANTS.}

For many years Hardy Perennials have been one of our principal specialties and our stock at the present time is unquestionably the most complete both in quantity and variety in the country.

Many planters not thoroughly familiar with this class of plants have an idea that nothing but a large, field-grown clump will give satisfactory returns the first season. This, as experience has taught us, is in most instances a mistake. A vigorous plant of proper size will, in nearly every case, give quicker and better returns than the best so-called "field-clumps" that can be procured. This fact is particularly appreciated by the leading Landscape Architects throughout the country who use Perennials in large quantity, the majority of whom give preference to the Dreer pot-grown plants. It will be moticed that the majority of the stock offered in this ist is described as being 3,4 or 5-inch pots. This does not necessarily mean that the plants have been altogether pot-grown, but that they have been fieldgrown and dug and potted up during the Fall and early Winter months, and such stock can be planted, even late in the Spring, with practically no loss, which, in the case of clumps, is often quite serious.

Acanthus (Bear's Breech).

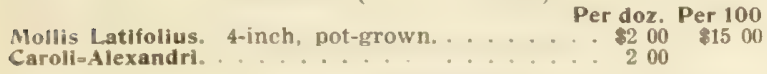

Achillea (Milfoil).

Boule de Neige. An improvement on "The Pearl,"

Eupatorium. Strong, 4 -inch pots

Fllipendula. Strong. $31 / 2$-inch pots

Miltefolium Roseum. 4-inch, pots

Cerise Queen. 4-inch pots

The Pearl. 3-inch pots.

Tomentose. 3-inch pots

\section{Aconitum (Monkshood).}

Autumnale

Fischeri...

Napellus

Napellus Aibus

Albus
Bicolor
Spark's Varlety

Wilsoni

$\begin{array}{llll}85 & 6 & 00 \\ 85 & & 6 & 00 \\ 85 & & 6 & 00 \\ 85 & & 6 & 00 \\ 85 & & 6 & 00 \\ 85 & & 6 & 00 \\ 85 & & 6 & 00\end{array}$

Actaea (Baneberry).

Spicata (White Baneberry). 3-inch pots Rubra (Red Baneberry). 3-inch pots : : 150

\section{Adenophora.}

Potanini. 3-inch pots

Polymoroha. 3-inch pots

\section{Adonis.}

Amurensis. $40 \mathrm{cts}$ each . ........... 400 flora olena. $40 \mathrm{cts}$ each. . . . 400

Agopodium (Bishop's Weed).

Podagraria Variegata. Strong 3-inch pots .... 100

\section{Athionema.}

Grandiflora. 3inch pots. . . . . 150

\section{Aetheopappus.}

Pulcherimus. Brilliant rose-colored flowers not unlike a Royal Sweet Sultan. $15 \mathrm{cts}$. each..... 150

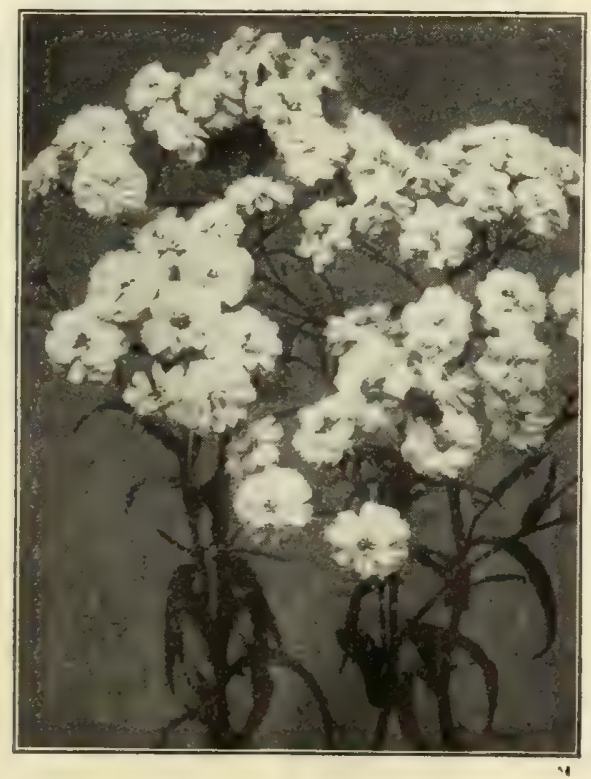

ACHILLEA, BOULE DE NEIGE

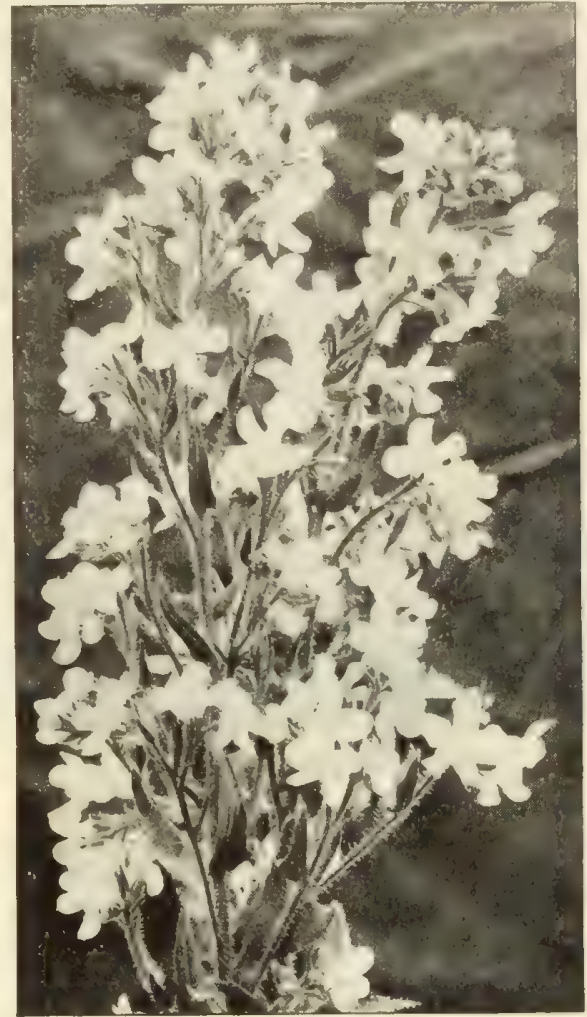

ANCHUSA ITALICA, DROPMORE VARIETY

Agrostemma (Campion)

Coronaria. 3-inch pots Per doz. Per 100 $\$ 085 \quad 2600$

Flos Jovis. 3-inch pots.

Ajuga (Bugle).

Reptans Rubra. 3-inch pots.

Alstromeria (Chilian Lily).

Chilensis

$$
\text { Alyssum. }
$$

Rostratum. 3-inch pots

Sexatile Compactum. 3-inch pots

\section{Amsonia.}

Salicifolia, Strong, 4-inch pots .

Anchusa (Alkanet).

Itallca, Dropmore Variety. Gentian blue

Italica, Opal. Light lustrous blu

italica, Perry's Variety. An improvement on the Dropmore variety; individual flowers fully an inch in diameter and of a rich deep blue.

Myosotidiflora. A new species growing but 10 inches high, sprays of beautiful Forget-me-not-like flow-

ers of rich blue. 35 cts. each.

\section{Anemone (Windflower)}

Pulsatilla. 4-inch pots

Sylvestris. 3-inch pots

Eliza Fellman. Double white: : $\begin{array}{llr}1 & 00 & 700 \\ 1 & 100 & 00\end{array}$

Nemorosa Robinsoni. 3-inch pots. . . . . $100 \begin{array}{rr}10 & 00 \\ & 00\end{array}$

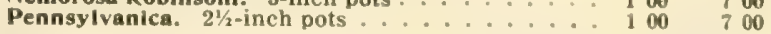




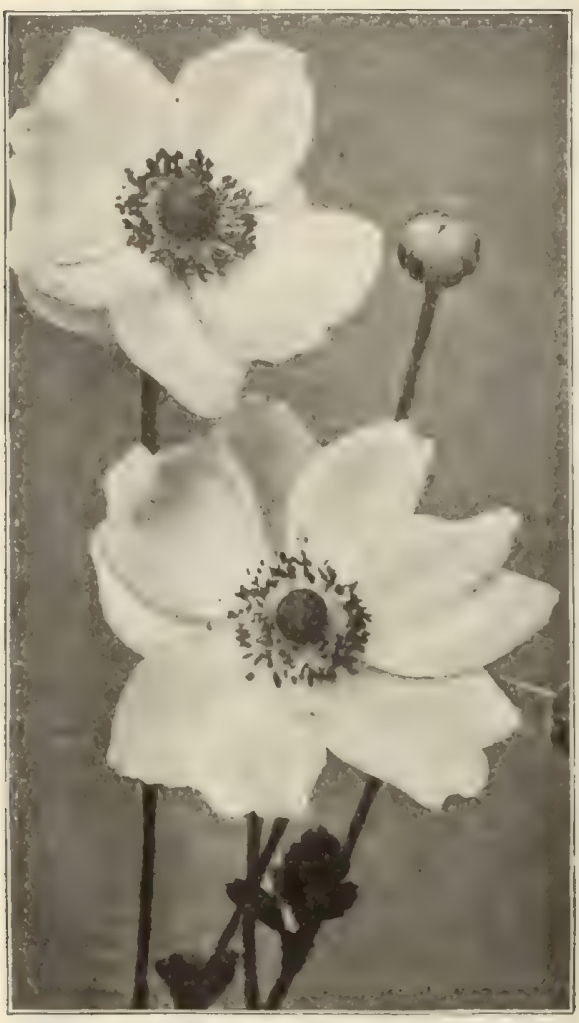

JAPANESE ANEMONE

Anemone Japonica (Japanese Windflower).

The stock which we are supplying is all in a growing condition in 3 -inch pots, and has not been injured by freezing; it is in shape to at once produce a strong vigorous growth

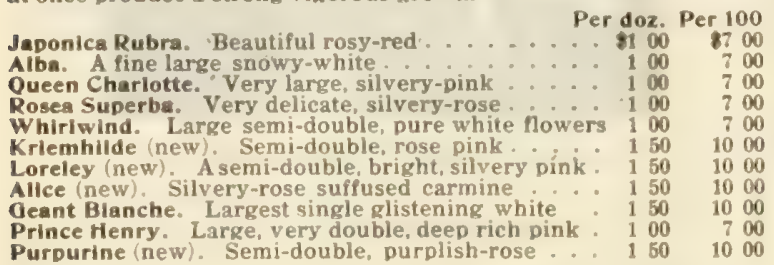

Anemonopsis.

Macrophylla. New. $50 \mathrm{cts}$. each

Anthemis (Marguerite).

Tinctorla. $2 \frac{1 / 4}{\text {-inch pots }}$

$$
\text { Alba. } 2 \frac{1}{4} \text {-inch pots }
$$

Nobllis (Chamomile). 4-inch pots

Anthericum (St. Bruno's Lily). Llilastrum Giganteum (Giant St. Bruno's Lily) . 200
Llliastrum. Strong Liliago. Strong

Aquilegia (Columbine).

Canadensis. Our native Columbine, bright red and yellow. Californica Hybrida. An extra fine mixture.

Carulea. The true blue Rocky Mountain Columbine.

Chrysantha. The beautiful golden-spurred Columbine.

Flabellata Nana Alba. Early dwarf, pure white.

Helena. Large blue and white flowers.

Nivea Grandiflora. Large, pure white.

Skinneri. Yellow with red spurs.

Skinneri. Yellow with red spurs.

Truncata. Scarlet with yellow tips.

Vulgaris. The European violet-blue Columbine.

Arabis (Rock Cross).

Aloina. Early flowering, single white Flore Plens. A double white form

Per doz. Per 100 $8085 \quad 8600$

\section{Arenaria (Sand Wort).}

Caespitosa. 3-inch pots

Montana. 3-inch pots
Armeria (Thrift-Sea Pink).

Per doz. Per 100 Maritima Splendens. 3-inch pots ......... \$0 $85 \$ 600$ Alba. 3-inch pots

\section{Aralia.}

Cashmerlana. 4-inch pots .......... 2001500

\section{Artemisia.}

Lactiflora. Panicles of creamy white Spiraa-like flowers

Abrotanum. 4-inch pots

Pedemontana. 4-inch pots

Purshians, 4-inch pots

Stellariana. 3-inch pots

Asclepias (Butterfly Weed).

Incarnata Rosea. Strong plants.... 100700

Tuberosa. Strong two-year field roots . . 85

Asperula (Sweet Woodruff. Waldmeister).

Odorata. 3-inch pots. . ........ $150-1000$

Asphodelus (Asphodel).

Luteus. 3-inch pots

\section{New Hardy Asters.}

Amellus Beaute Parfait. The finest of this type yet introduced Grows about 15 inches high; flowers royal violet-purple with yellow centre.

Abendroth (Evening Glow). One of the most effective September and October flowering varieties with rosy-red flowers.

Beauty of Colwall. Large semi-double flowers of ageratum blue. $\$ 2.00$ per doz.; $\$ 15.00$ per 100 .

Beauty of Ronsdorf. Forms densely branched symmetrical plants, 15 to 18 inches high, covered with tender rose-lilac flowers distinct from all others. $\$ 2.00$ per doz.; $\$ 15.00$ per 100

Feltham Blue. One of the most decorative free-flowering blue varieties. August and September, $2 \%$ feet high. 82.00 per doz. $\$ 15.00$ per 100 .

Laevis Baidur. Light parma-violet. September.

Mesa Grande Speciosa Grandiflora. The finest dark purplish-blue

Thompsoni Nana. Venetian-blue of oretty stellate form.

Price. Except where noted, $\$ 1.50$ per doz; $\$ 10.00$ per 100

Aster Alpinus (Hardy Alpine Aster). Perdoz. Per 100 Alpinus. Blue, 9 -inch pots ........... $8100 \$ 700$ Albus. White, 3-inch pots … 100700

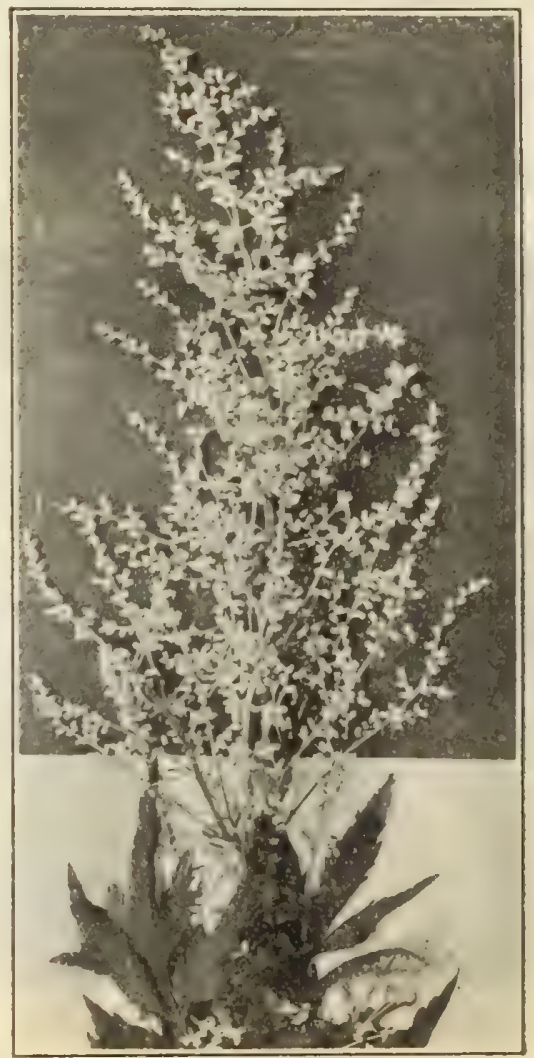

ARTEMISIA LACTIFLORA 
Hardy Asters (Michaelmas Daisies, or Starworts).

These are among the showiest of our late flowering hardy plants. The collection offered below is made up of the choicest varieties only, the weedy sorts being eliminated. Unless otherwise specified, they bloom in September and October.

Acris. Masses of bluish-violet flowers. I foot.

Nanus. Masses of bluish-violet flowers. 6 inches.

Curtisil. Pale heliotrope. August and September. 3 feet.

Dornroschen. Mauve, with light halo. 2 feet.

Formosissima. Bright violet 3 feet.

Herbstelfe. Light lavender blue. 3 feet.

Lavis. Lavender blue. 4 feet.

"Floribunda. Light heliotrope. 4 feet.

Mme. Soyneuse. Pale lilac, very free. 15 inches.

Novae Angliae. Bright violet-purple. 4 feet.

Mrs. F. W. Raynor. Crimson-purple. $4 \frac{1}{2}$ feet.

Rosea. Bright purplish mauve. 4 feet

Rubra. Large rosy-purple. 4 feet.

". ". Wtarmicoides. Pure white, useful for cutting. August and September. 18 inches.

Puniceus Pulcherrimus. Bluish-white with yellow centre. 5 feet. Snowflake. Very free, pure white. 18 inches.

Sub=Caruleus. Forms a dense tuft, throwing up during June and

July many leafless 12 inch high stems of massive bluish-violet flowers.

Tartaricus. Large bluish-lilac. 6 feet.

Tartaricus, Large bluish-lilac.

Top Sawyer. Clear parma-violet color 4 feet.

Trinervus. Rich violet-purple. October and November. $2 \frac{1}{2}$ feet. White Queen. Fine pure white. 4 feet.

Strong divisions. $\$ 1.00$ per doz.; $\$ 7.00$ per 100 .

\section{Astilbe Arendsi.}

This new type is of very vigorous growth, producing many. branched, feathered heads of flowers. $2 \frac{1 / 2}{2}$ to 3 feet high.

Ceres. Delicate, light rose with silvery sheen.

Juno. Strong upright plumes of deep violet rose.

Salmon Queen. Beautiful salmon pink.

Venus. Deep violet rose.

Vesta. Light lilac rose.

White Plumed. Dense pyramidal plumes of silvery white. 35 cts. each; $\$ 3.50$ per doz.

Choicest Mixed Varieties of above, $\$ 2.00$ per doz.; $\$ 15.00$ per 100 .

\section{Astilbe.}

Davidil. Feathery plumes of deep rose violet flowers during July and August. $\$ 1.50$ per doz. $\$ 10.00$ per 100 .

Grandis. Panicles of white flowers. 20 cts. each; 2.00 per doz. $\$ 15.00$ per 100

Astrantia (Master-Wort). Per doz. Per 100

Major. 3-inch pots ............. \$2 00 \$1500

Aubretia (False Wall Cress).

Bougainvillel. 3-inch pots ......... 85600 Leichtlini. 3-inch pots............ $85 \quad 600$

Baptisia (False Indigo).

Australis. Strong plants............ 1007700

Tinctoria.

Bellis (English Daisies).

Dowble White and Pink .......... $40 \quad 300$

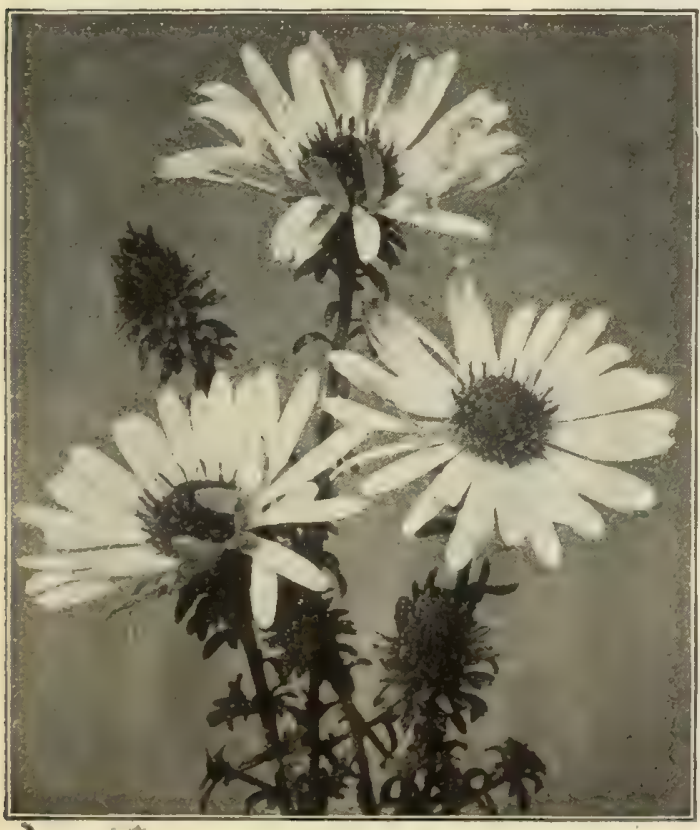

HARDY ASTERS, OR MICHAELMAS DAISIES

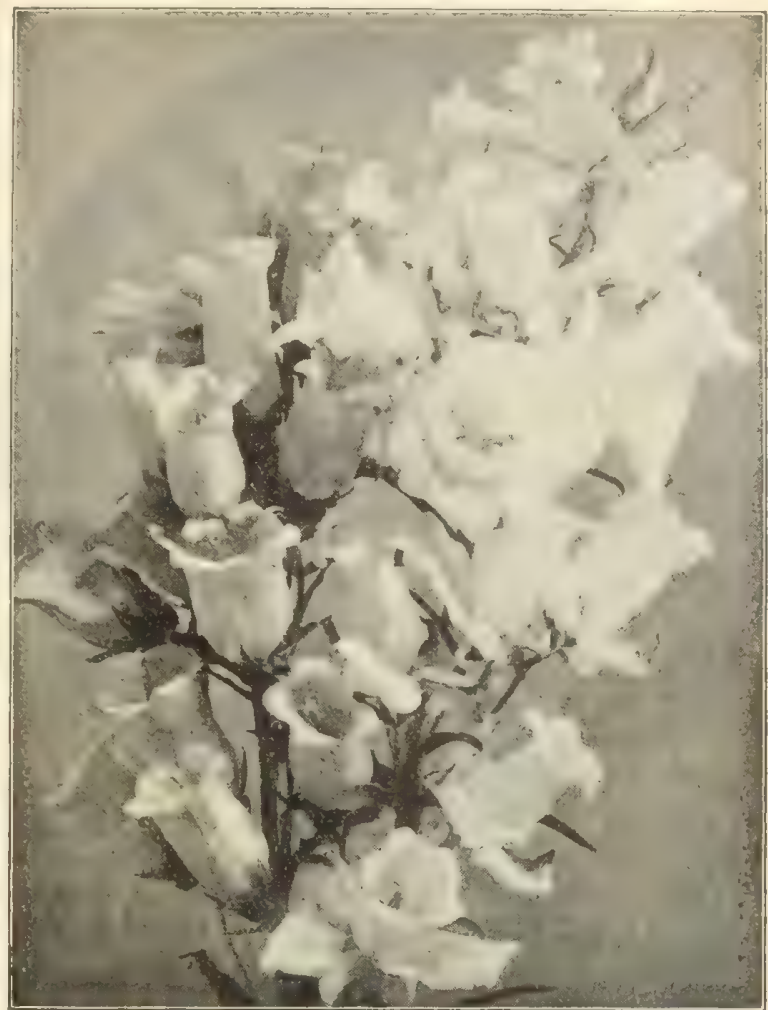

Campanula medium (Canterbury Bells)

Bocconia (Plume Poppy). Perdoz. Per.100

Cordata. Strong divisions . $\$ 100 \$ 700$

Boltonia (False Chamomile).

Asteroldes. 31/2-inch pots ............. 858600

Latisquama.
Nana. 31/2-inch pots

\section{Hardy Cactus.}

Echinocactus Simpsoni (Hedge Hog Cactus)

Echinocereus Viridiflora (Green-flowered Cereus) \& $125 \quad 1000$ puntia Arenaria .

"Rafinesquii

“ Phaeacantha Major (Gay-spined Cactus) 1251000 (Gay-spined Cactus) : 150

1000

\section{Calimeris (Star Wort.)}

Incisa. $3 \frac{1}{2}$-inch pots

Callirhoe (Poppy Mallow).

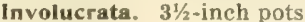

Caltha (Marsh Marigold).

Palustris. 3-inch pots

Flore Plena. 3 -inch pots

Campanula (Bell-flower).

Alliariaefolla. 3-inch pots

Carpatica. Blue. 3-inch pots

Grosseki. 3-inch pots

Latifolia Macrantha. 3-inch pots

Medium (Canterbury Bell). Blue, white and rose. 4-inch pots

Persicifolia, 3winch pots

Alba. 3-inch pots

Punctata. 3-inch pots

Pyramidalis. 4-inch pots

Rapunculoides, 4-inch pots

Rotundifolia. 3 -inch pots

Trachelium. 4-inch pots

$\begin{array}{lllll}1 & 00 & & 7 & 00 \\ 1 & 00 & & 7 & 00 \\ 1 & 00 & & 7 & 00 \\ 1 & 00 & & 7 & 00 \\ 1 & 00 & & 7 & 00 \\ 1 & & & & \\ 1 & 00 & & 7 & 00 \\ 1 & 25 & & 8 & 00 \\ 1 & 25 & & 8 & 00 \\ 1 & 00 & & 7 & 00 \\ 1 & 25 & & 8 & 00 \\ 1 & 00 & & 7 & 00 \\ 1 & 00 & & 7 & 00 \\ 1 & 00 & & 7 & 00\end{array}$

Caryopteris (Blue Spiræa).

Mastacanthus. 3-inch pots

Cassia (American Senna). 


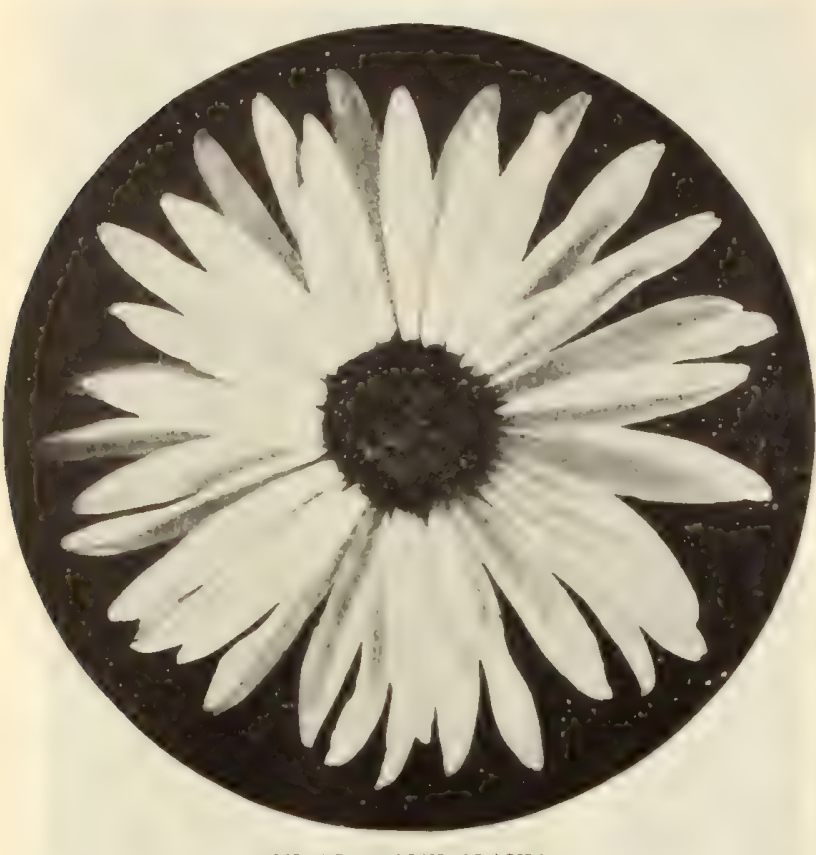

SHASTA UAISY ALASKA

Catananche.

Per doz. Per 100

Coerulea and Bicolor. S-inch pots........ $8085 \$ 2600$

\section{Centaurea (Hardy Com-Flowers).}

Dealbata, 4-inch pots ........... 100

Hirta Nigra Variegats. 4-inch pots . . . : 100

Macrocephale. tinch pots........... 100

Montana. 4-inch pots

Alba 4-inch pots

Orientalls. A-inch pots

Ruthenica. 3-inch pots

\section{Cephalaria (Round Heads).}

Alpina, 4-inch nots

\section{Cerastium (Snow in Summer)}

Tomentosum. 3-inch pots

Chelone (Shell Flower).

Glabra Alba, $3 \frac{1}{2}$-inch pots

Lyonll. $31 / 2$-inch pots

Speciosa. $3 \frac{1}{2}$-inch pots

\section{Hardy Pompon Chrysanthemums.}

Allentown. Golden bronze

Baby. A miniature lemon yellow.

Baby Margaret. A miniature white.

Bohemla. Fine pure yellow.

Boston. Golden bronze.

Canary. Pale yellow.

Cerise Queen. Cerise pink.

Dawn. Daybreak pink.

Dawn. Daybreak pink.

Eagle d'Or. Golden yellow.

Flora, Deep golden yellow.
Gold Nugget. Golden yellow, tinged red.

Golden Pheasant. Rich golden yellow.

Julia Lagravere. Rich garnet.

King Henry, Straw white.

King Philid. Rich rose pink

Lula. Pure white.

L'Aml Couderchet. Sulphur white.

Lititle Pet. Violet crimson.

Model of Perfection. Beautiful white.

Mrs. Porter. Bright bronze.

Mrs. Vincent. Dark crimson.

Mrs. Vincent. Dark crimson.

Overbrook. Chrome yellow.

Princess of Wales. A fine white.

Princess of Wales. A fine white.

Queen of Bulgarla. Ri

Rosinante. Blush rose.
Sir Michael. Lemon yellow.

Sour Melanie. Pure white.

Sunshine. Bright golden yellow.

Tennyson. Pure yellow.

Thalla. White, yellow centre.

The Hub. Fine white.

Tiber. Crimson brown, tipped yellow.

Trolan. Maroon, with yellow centre.

Veuve Clicquot. Brick-red, edged yellow.

Strong thrifty young plants, 60 cents per dozen: $\$ 4.00$ per 100 .
Chrysanthemums (Moonpenny and Shasta Daisies). Shasta Daisy, "Alaska," 9-inch pots ...... \$1 $50 \quad \$ 1000$ Shasta Daisy. Mixed seedlings, 3-inch pots . . $75 \quad 500$

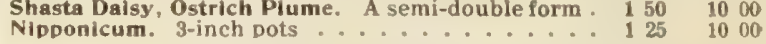

Chrysanthemum Arcticum (The Arctic Daisy).

Masses of Shasta Daisy-like white flowers, from 2 to $2 \frac{1}{2}$ inches in diameter. These begin to develop during the last week in September and continue in good condition throughout October. \$2.00 per doz.; $\$ 15.00$ per 100

\section{Large-flowering Hardy Chrysanthemums.}

Fine large-flowering sorts that stood out through the severe winter of 1911.

Autumn Glow. Rose-crimson

Indian. Indian-red

Golden Queen. Yellow

old Homestead. Pink

Victory. White

$\begin{array}{rrr}\text { Per doz. } & \text { Per } 100 \\ \therefore \quad \$ 100 & \$ 700 \\ 1 & 100 & 700 \\ \therefore \quad 100 & 700 \\ 1 & 100 & 700 \\ 100 & 700\end{array}$

Cimicifuga (Snakeroot).

Acerinum, or Japonicum. Strong roots .... 2 001500 Dahurica. Strong roots............ 2001500 Racemosa. Strong roots -12580 ets. each: $\$ 2.50$ per doz.

Clematis.

Per doz. Per 100

Davidiana. 3-inch pots.

Heracleatolia. 3-inch pots

Recta. 2-year-old plants

$2085 \quad 8600$

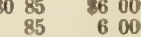

$\begin{array}{rr}85 & 600 \\ 150 & 1200\end{array}$

Recta Flore Plena. A rare double-flowering form. $35 \mathrm{cts}$. each $\$ 3.50$ per doz.

Virginica.

Claytonia (Spring Beauty). Per doz. Per 100 80752500

\section{Convallaria (Lily of the Valley).}

Majalls. Strong clumps

\section{Coreopsis.}

Lanceolata Grandiftora. 4-inch pots, heavy ... 858600

Rosea. 31/s-inch pots . . . . . . . . $85 \quad 600$

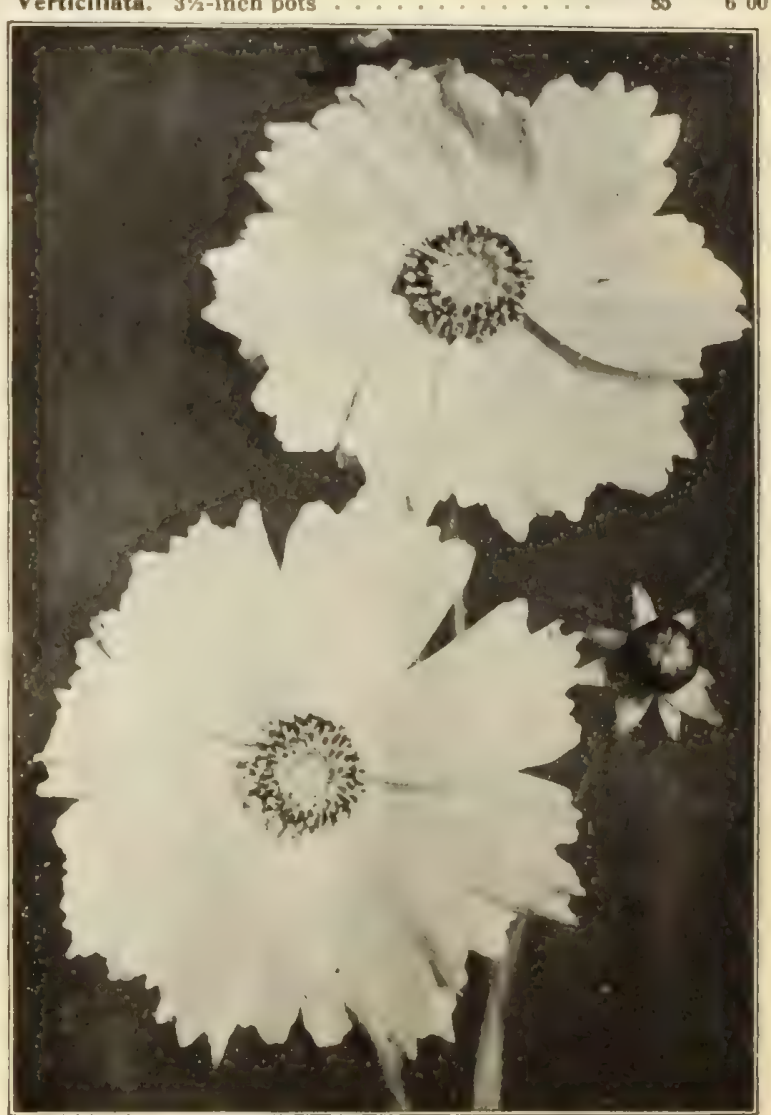

COREOPSIS LANCEOLATA GRANDIFLORA

Victor. Rosy crimson. 


\section{Choice Hybrid Delphiniums.}

Amos Perry. Rich rosy mauve flushed sky-blue; black eye. 25 cts. each; $\$ 2.50$ per doz.: $\$ 20.00$ per 100 .

Belladonna. The freest of all. Beautiful turquoise-blue. 15 ets. each; $\$ 1.50$ per doz:; $\$ 12.00$ per 100 .

Capri. Large flowers of a beautiful sky-blue. 35 ets. each; $\$ 3.50$ per doz.

Carmen. Deep Gentian-blue; centre rosy plum with a deep brown eye. 30 ets. each. $\$ 3.00$ per doz.; $\$ 25.00$ per 100 .

Duke of Connaught. Rich Oxford-blue, with bold white eye. 25 cts. each; $\$ 2.50$ per doz.: 820.00 per 100 .

Felicite. Sky-blue flowers with black eye. 25 cts. each; $\$ 2.50$ per doz.

Julia. Cornflower-blue, veined with rose; large pure white eye, 25 cts. each; $\$ 2.50$ per doz.. \$20.00 per 100 .

Lamartine. Similar in habit to Belladonna, but with rich Gentian-blue flowers with Lamartine. Similar in habit to Belladonna, but with rich

Lizzie. Splendid azure-blue flowers with bold yellowish eye. 30 cts, each; $\$ 3.00$ per doz.

Mrs. Creighton. Semi-double flowers, outer petals sky-blue, centre rich plum with black eye. 30 cts, each; $\$ 3.00$ per doz. $\$ 20.00$ per 100 .

Moerhelimi. This is the first really white hybrid Delphinium introduced. $35 \mathrm{cts}$. each; $\$ 3.50$ per doz.

Musea. Large semi-double flowers of a rich Cambridge-blue, inner petals rosylavender with black eye. 25 cts. each; $\$ 2.50$ per doz.

Queen Withelmina. Soft lavender blue, flushed rose, conspicuous white eye. 30 cts. each; \$3.00 per doz:; $\$ 25.00$ per 100.

Rev.J. J. Stubbs. Rich azure-blue with bold black eye with many conspicuous yellow hairs. $25 \mathrm{cts}$. each; 82.50 per doz.

\section{Select Standard Varieties of Delphiniums.}

Chinense. Free-flowering, gentian-blue

Chinense Alba. A white form of the above

Formosum. The old favorite dark-blue variety

Sulphureum (Zalil). Pure sulphur yellow

Gold Medal Hybrids. Unquestionably the finest strain of mixed hybrids ever offered; grown from seed produced by one of the best named collections

Per doz. Per 100 $8085 \quad 8600$ 8500 $200 \quad 1500$

$125 \quad 800$

\section{Dianthus Countess Knut.}

A hybrid variety, growing about 24 inches high; double flowers of a pleasing shade of yellowish salmon. 20 cts, each; $\$ 2.00$ per doz.; 15.00 per 100 .

\section{Dianthus.}

Barbatus (Sweet William). Strong 4-inch pots

Barbatus Newport Pink. 4-inch pots

Deltoides Alba. 3-inch pots

$$
\text { Rosea. 3-inch pots }
$$

Latifolius Atrococcineus, FI. PI. 21/4-inch pots

Plumarius. (See Hardy Pinks.)

Dictamnus (Gas Plant). Fraxinella Alba. Strong .

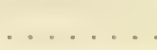

Caucasicus. A gigantic form. 15 cents each

Per doz. Per 100

$\begin{array}{rrr}\$ 1 & 25 & \$ 800 \\ 1 & 25 & 800\end{array}$

\section{Dielytra (Bleeding Heart).}

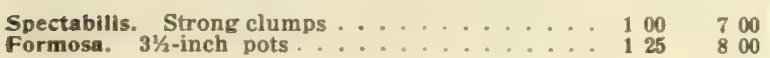

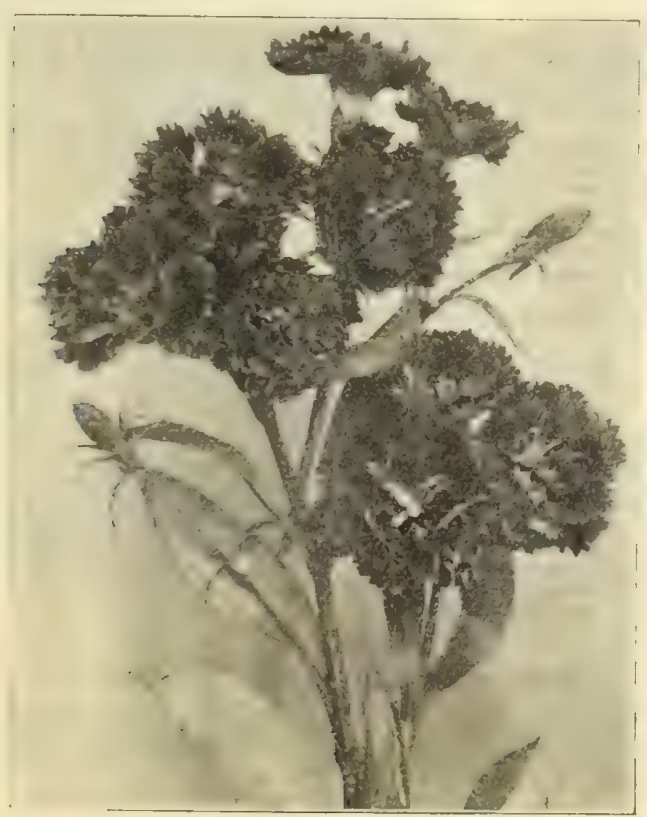

DIANTHUS LATIFOLIUS ATROCOCCINEUS, FL. PL.

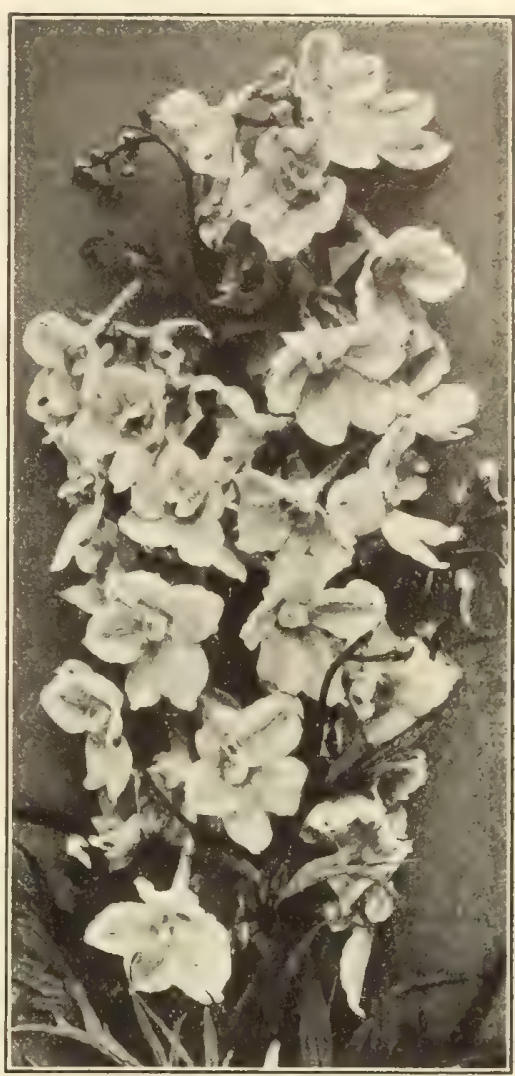

DELPHINIUM BELLADONNA

Digitalis (Foxglove).

Per doz. Per 100 $\$ 085 \$ 300$

Ambigua or Grandiflora. Strong, 3/1/2-inch pots Gloxiniaflora. White, purple, rose, lilac or mixed.

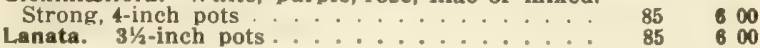
Meadia

Dodecatheon (American Cowslip or Shooting Star).

125800

Doronicum (Leopard's Bane).

Caucasicum. 3-inch pots

Clusil. 3-inch pots

$125 \quad 800$

Excelsum, 3-inch pots

125800

Draba (Whitlow Grass).

Androsacea. 3-inch pots

Echinops (Globe Thistle).

Banaticus. $3 \frac{1}{2}$-inch pots

Ritro. 4-inch pots

Ruthenicus, $3 \frac{1}{2}-$-inch pots

Spharocephalus. $3 \frac{1}{2}$-inch pots

Eomecon (Eastern Poppy).

Chionantha. 3-inch pots

Epilobium (Willow-Herb).

Hirsutum. 3-inch pots

Epimedium (Barrenwort or Bishop's Hat).

Alpinum. Crimson and yellow ......... 1501000

Niveum. Pure white. 1501000

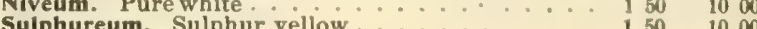

Sulphureum. Sulphur yellow. . . . . . . . . 150
Vlolacea. Reddish violet. 1000 
Erigeron (Fles Bane). Per doz. Per 100 Intermedium. Delicate rose-tinted white. $15 \mathrm{cts}$. each $\$ 150$ Glabellus. $3 \frac{1}{2}$-inch pots ............. 100 Grandiflorus Elatior. $3 \frac{1 / 2 \text {-inch pots } \ldots \ldots \ldots}{1} 00$ Erinus.

Aldinus Carminea. 3-inch pots $\$ 700$ Eryngium (Sea Holly.)

Amethystinum. 4-inch pots Maritimum. 3-inch pots Planum. 4-inch pots

\section{Euonymus Kewensis.}

A splendid evergreen for carpeting or rock-plant, with small, dark green leaves with ighter veins. 20 cents each: $\$ 2.00$ per dozen. Azeratoides. $3 \frac{1}{2}$-inch pots Coelestinum. 3-inch pots Maculatum. 4-inch pots

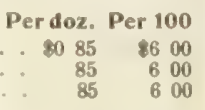

\section{Euphorbia (Milk-Wort).}

Corollata. Strong roots

Cyparissias. $3 \frac{1}{2}$-inch pots.

Polychroma. 4-inch pots.

$\begin{array}{rrrr}85 & 6 & 00 \\ 1 & 50 & 10 & 00 \\ 1 & 50 & 10 & 00\end{array}$

\section{Hardy Ferns.}

Adiantum Pedatum (Hardy Maiden Hair)

Aspldium Acrosticholdes (Wood Fern) Marginale Goldianum (Shield Fern) Nova boracense

Asplenium Fellx-foemina

$$
\begin{aligned}
& \because \text { Cragil Laciniatum } \\
& \because \quad \text { \# } \quad \text { Multifidum } \\
& \because \text { " } \\
& \text { * Goringianum Pictum. }
\end{aligned}
$$

Dicksonia Punctilobula (Gossamer Fern) Lestrea Chrysolobo

- Dilitata

.. Fellx-mas

Fluctuosa

Nephrodium Hertipes

Onoclea Struthlopterls (Ostrich Fern) Sensibillis (Sensitive Fern

Osmunda Claytonla (Flowering Fern) Cinnamomea (Cinnamon Fern)

Polystichum Brauni Cinnamomea (Cinna
Regalis (Royal Fern) Lobatum Setosum

Rare Hardy Harts-tongue Ferns.

Scolopendrium Vulgare. The ordinary English Harts-tongue. $\$ 2.00$ per dozen; $\$ 15.00$ per 100 .

Scolopendrium Vulgare Digitato Cristatum. Ends of fronds much branched and crested. 83.50 per dozen; $\$ 25.00$ per 100 .

Scolopendrium Vulgare Marginatum. Edges of fronds deeply Scolopend rium
serrated. $\$ 30$ per dozen; $\$ 25.00$ per 100.

Scolopendrium Vulgare Undulatum. Edges of fronds beautifull waved and crested. $\$ 3.50$ per dozen; $\$ 25.00$ per 100.

$\begin{aligned} & \text { Feverfew. } \text { Per doz. Per } 100 \\ & \text { Littie Gem. } 21 / \text {-inch pots. . . . . . . . } 80758500\end{aligned}$

Funkia (Plantain or Day lily)

Alba Marginate

Carrulea (Blue Day Lily)

Cartulea

Fortunel Gigantea (New). $35 \mathrm{cts}$, each

Subcordata Grandifiora. White.

Subcordata Grandifiora.

Robusta Elegans Variegata. A decided improvement

on all variegated varieties. 15 cents each

Minor Albs

Sieboldiana

Thomas Hoge

Gaillardia (Blanket Flower).

Grandiflora. 4-inch pots, fine

Galega (Goat's Rue).

Duchess of Bedford (New). 20 cts. each

Officinalis. $3 \frac{1}{2}$-inch pots

$$
\text { Alba. } 3 \frac{1 / 2}{\text {-inch pots }}
$$

\section{Gentiana (Gentian.)}

Andrewsi (Closed Gentian). 3-inch pots

Geranium (Crane's Bill).

Grandiflorum. 3-inch pots

Pratydiflorum. 3-inch pots

Sanguineum. 4-inch pots

$$
\text { Album. 4-inch pots }
$$

100

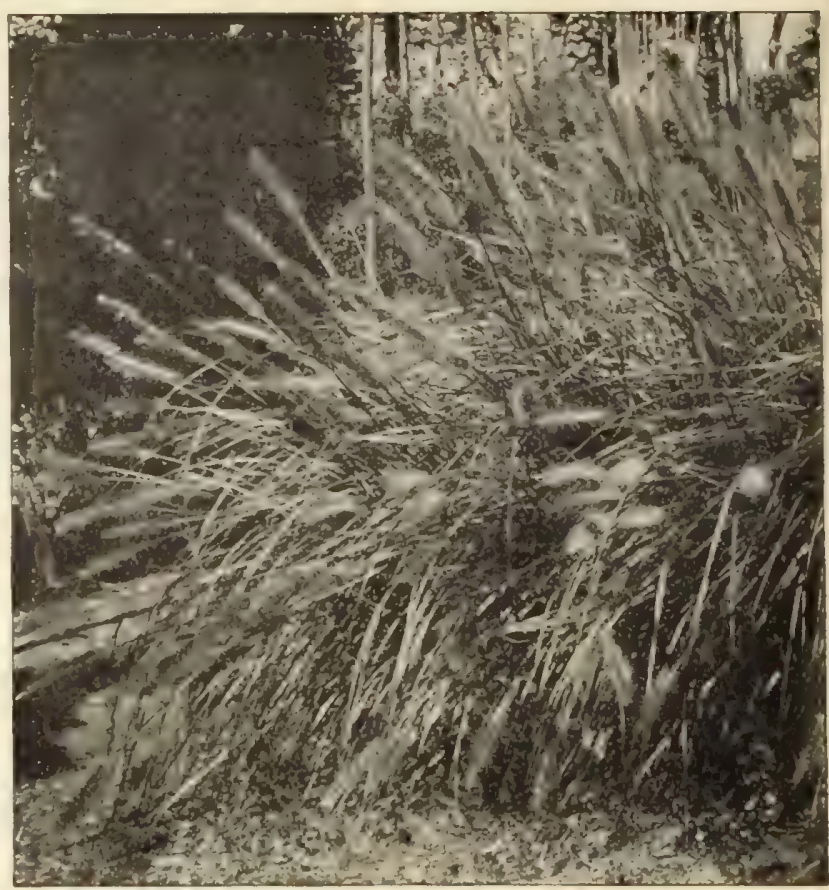

PENNISETUM JAPONICUM (Hardy Fountain Grass).

Geum (Avens).

Atrosanguineum. 3-inch pots

Coccineum. 3-inch pots

Mrs. Bradshaw (New). 3-inch pots

Gillenia (Bowman's Root).

Trifollata

Glechoma or Nepeta.

Variegata (Variegated Groundsel or Ground Ivy). 3 -inch pots

ORNAMENTAL GRASSES.

These are now used very extensively for beds, specimens on lawns, etc. etc. We grow the leading varieties in large quantities. For full descriptions, see pages 219 and 220 of our Garden Book for For full.

Arundo Donax. Strong, dormant eyes.

Donax Varlegata. Strong, dormant eyes Arrhenatherum Bulbosum folla Variegate

Elymus Glaucus (Blue Lyme Grass)

Erlanthus Ravennae. Strong according to size

Per doz. Per 100 $\$ 150 \$ 1000$

$200 \quad 1500$

$150 \quad 1000$

Eulalla Japonica Varlegate Gaponica Zebrina

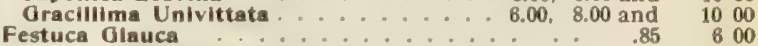

Gynerlum Argenteum $\cdots \cdots 250 \quad 2000$

Panicum Virgatum . . . . . 100700

Phalaris Arundinacea Variegata. (Variegated Rib- $85 \quad 600$

Uniola Latifolla. (Spike Grass) .... . 100700

\section{Pennisetum Japonicum ( New).} (Hardy Fountain Grass).

This new variety, offered for the first time last year, has been on trial with us for the past three seasons, and has proved to be perfectly hardy, In habit of growth it is somewhat heavier than $P$. Rueppelianum: grows about 4 feet high; foliage narrow, of a bright creen, while the cylindrical flower heads, carried well above the Ereen, while the cylindrical flower heads, carried well above the light, airy appearance, and should prove one of the most valuable hardy grasses either for use in beds, mixed borders or as specimens. $\$ 1.25$ per doz: $\$ 8.00$ per 100 .

Eulalia Japonica Zebrina Stricta (New).

Identical with the well-known hardy Zebra Grass, excepting in habit of growth, which is more erect, and on account of which the transverse variegation of yellow and green appears more pronounced. 15 cts. each ; $\$ 1.50$ per doz.; $\$ 10.00$ per 100 .

For Hardy Bamboos see next page. 


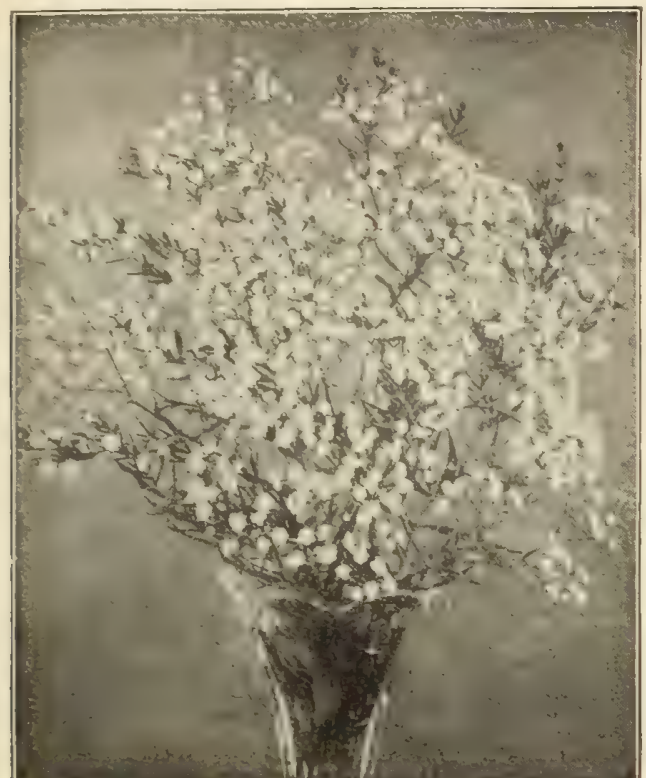

gYPSOPHILA PANiculatA, FL. PL。

\section{Ornamental Hardy Bamboos.}

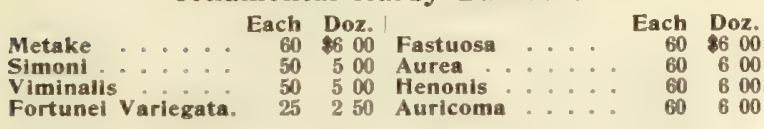

\section{Gunnera.}

Scabra. Fine strong plants in 5-inch pots of this grand foliage plant. 35 cents each; $\$ 3.50$ per dozen.

\section{Gypsophila (Baby's Breath).}

Paniculata Flore Plena. This double flowering Gypsophila is one of the most important hardy plants for cutting purposes. Strong plants, 20 cts, each; $\$ 2.00$ per doz.; $\$ 15.00$ per 100

Acutifolia. Strong roots

Cerastioldes, 4-inch pots

Paniculata. One-year-old

Per doz. Per 100

\begin{tabular}{rrr}
100 & 8700 \\
\hline & 100
\end{tabular}

Helenium (Sneezewort).

Autumnale Superbum. 4-inch pots

Autumnale Rubrum. Bright terra cotta-
Grandicephalum Striatum. 3-inch pots

Hoopesi. 3-inch pots. . . . .

Pumilum Magnificum. 3-inch pots

Riverton Gem. Flowers of old gold, changing as they mature to wallflower-red

Riverton Beauty. Lemon-yellow, with a large disc

of purplish-black .......

Helianthemum (Rock Rose),

Alpestre. 3 -inch pots

Mutabile. 3-inch pot

Helianthus (Hardy Sunflower).

Daniel Dewar. Strong plants

Giganteus.

Mollis Grandiflorus. Strong plants

Multiflorus, f1. pl. Strong plants

$$
\text { .. Maximus. Strong plant }
$$

$\therefore$ Meteor. Strong plants

Sollel d'Or. Strong plants

Maximilliana. Strong plants

Orgyalis. Strong plants

Rigidus Japonicus. Strong plants

Sparsifolius.

Wolley Dod. Strong plants

Heliopsis (Orange Sunflower).

Pitcheriana. 4-inch pots

Semi-plena. 'Semi-double flowers

Scabra Zinniaflora. A new double-flowering form. 20 cts. each; $\$ 2.00$ per doz.

Helleborus (Christmas Rose).

Niger. Strong clumps. $\$ 2.50$ per doz,; $\$ 20.00$ per 100

600

600

600

600

600

600

\section{Four Handsome Hemerocallis.}

The varieties here offered are great improvements upon the well-known yellow Day Lilies.

Queen of May (new). A splendid new hybrid, flower stems from 3 to 5 feet high, terminated with from 12 to 18 flowers of largest size of a rich Indian-yellow. The flowers begin to develop in May and continue for nearly two months; perfectly hardy. 25 cts. each; $\$ 2.50$ per doz.; $\$ 18.00$ per 100 .

Aurantiaca. Very large, bright, orange-yellow, sweet-scented flowers. 20 cts, each ; $\$ 2.00$ per doz.; $\$ 15.00$ per 100.

Aurantiaca Major. Large trumpet-shaped, sweet-scented, deep orange flowers. Requires protection. $20 \mathrm{cts}$, each $\$ 2.00$ per doz. 15,00 per 100.

Florham. Large golden-yellow, sweet-scented flowers; very free flowering. $20 \mathrm{cts}$. each ; $\$ 2.00$ per doz.; $\$ 15.00$ per 100 .

Hemerocallis (Day Lily). Per doz. Per 100

Dumortieri ................ \$0 $85 \$ 800$ Fulva. (Tawny Day Lily) . . . . . . . . 858600 Flava (Yollow' Day Lily) . . . . . . . . . $\quad \begin{aligned} & 85 \\ & 85\end{aligned}$ Gava, (Yellow Day Lily

Middendorf

Thunbergi

Hepatica (Liver Leaf).

Angulosa, Blue, 3-inch pots ......... 1258800 Triloba. 3-inch pots. 125800

Herniaria (Turk's-herb).

Olaber. 3-inch pots ........ 100700

Hesperis (Rocket).

Matronalis. Strong plants . . . . . . . . 8 $85 \quad 600$

Heuchera (Alum Root).

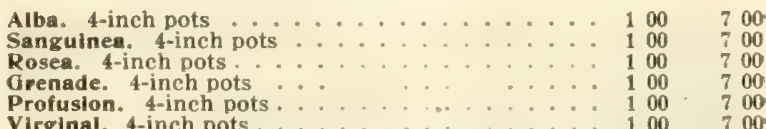

\section{New Giant=Flowering Marshmallows (Hibiscus).}

A wonderfully improved form of our greatly admired native Marshmallow or Rosemallow, in which not only the colors have been greatly intensified but in which flowers of enormous size, frequently 10 to 12 inches in diameter, have been developed.

These plants can be highly recommended for all kinds of plantings. they appear to be equally at home in all positions, having the same vigor in dry and wet ground and are perfectly hardy, they grow from 5 to 8 feet high and are very floriferous, blooming from early in July to late in Autumn. We offer three distinct colors, Red, Pink and White in strong two year old roots. 35 cts., each; $\$ 3.50$ per doz.

Hibiscus (Mallow). Per doz. Per 100

Militaris. Strong one-year-old

Moscheutos. Strong one-year-old

Marvel Marimson Eye. Strong one-year-old $85 \quad 600$

Hieracium (Hawk-weed).

Aurantiacum. 3-inch pots

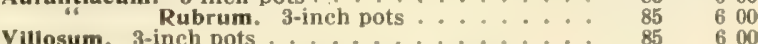

\section{Dreer's Superb Hollyhocks.}

We have this season a fine lot of strong, clean, healthy, vigorous one-year-old flowering plants of the finest strain, as under.
Double White,
Double Yellow,
Double Maroon.

$\$ 1.50$ per doz.; $\$ 10.00$ per 100 .

Per doz. Per 100

Double Mixed
Double Fringed Allegheny $\ldots \ldots \ldots$

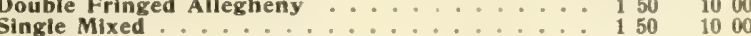

Houstonia (Bluets, Quaker Lady or Innocence)

Serpylifolla 3-inch pots 00.125

Hypericum (St. Jobn's Wort). 


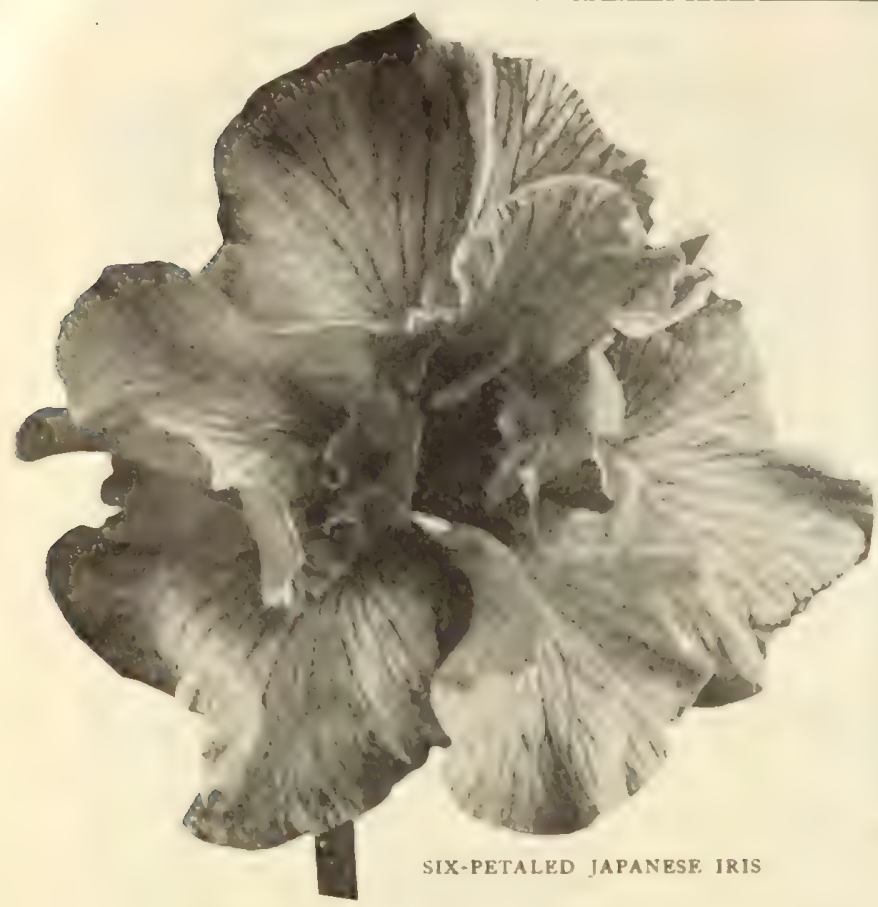

IRIS GERMANICA.

Our collection of German Iris is very choice, the varieties offered being the best in their respective colors.

Asiatica. Standards light blue, falls dark blue.

Blue Boy. Standards and falls a beautiful lavender-blue.

Cherion. Standards lilac-mauve, falls violet-mauve.

Edith. Standards light blue; falls violet-purple with white veins.

Florenting Alba. Sweet scented. early flowering white.

Gazelle. White, heavily frilled with rich mauve.

Honorabilis. Standards golden-yellow, falls mahogany-brown.

John De witt. Standards bluish-violet, shading lighter towards

the centre; falls deep violet-purple veined with white.

Jordan. Standards and falls light mauve.

La Tendresse. Ageratum-blue, shading lighter with brown veins.

Lord Sallsbury. Standards amber and white; falls dark violet purple with white veins.

Mad. Chereau. Pure white, prettily edged with light blue

Mme. Paquette. Soft rosy-lilac; pretty.

Mrs. H. Darwin. Standards white, falls slightly veined with violet.

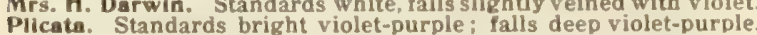

Plicata. Standards bright violet-purple; falls deep violet-purple. Shakespeare. Standards straw-yellow veined with burnt
falls deep carmine-violet, shaded deeper and white veins.

falls deep carmine-violet, shaded deeper and white veins.
spectabilis. Standards light violet-purple ; falls deep violet-purple

Spectabilis. Standards light violet-purple ; falls deep
with dark shadings; one of the earliest to flower.

Price Named Sorts. 10 cts. each ; 85 cts. per doz.; 28.00 per 100

Mixed German Iris. All colors. 60 cts. per doz.; 4.00 per 100.

\section{New German Iris (I. Germanica).}

King of Iris, Standards clear lemon-yellow: falls deep satinybrown with a broad border of golden-yellow.

Lohengrin. Of gigantic size, deep violet-mauve.

Mithras. Standards pale-yellow: falls violet-shaded claret, with yellow border.

Nibelungen. Standards olive-green suffused sulphur-yellow; falls deep violet-purple, suffused creamy-white on edges. Princess Victoria Louise. Standards pure sulphur-yellow; falls

Rhein Nixe. Standards pure white; falls deep violet-blue with white margin.

Price. Any of the above new varieties, 30 cts. each; $\$ 3.00$ per

doz. One each of the set of 6 sorts for $\$ 1.50$.

\section{Iris Pallida.}

Pallida Dalmatica. One of the finest of the Germanica type. The plant is of strong habit, growing 4 feet high, with exceptionally large flowers, the standards of a fine lavender, the falls lavender shaded blue; fine for massing. $\$ 3.50$ per doz.; $\$ 10.00$ per 100 .

Pallida Dalmatica Folia Variegata. Foliage variegated, with broad bands of creamy-yellow. 35 cts. each; $\$ 3.50$ per doz.

Pallida Speciosa. Standards dark-lavender, falls light-purple. very free flowering. $\$ 1.50$ per doz.; $\$ 10.00$ per 100 .

\section{New Iris Interregna.}

A new type, the result of crossing Iris Germanica with I. Pumila Hybrida, and for which there promises to be a great future. Gerda. Standards light cream; falls deeper, with golden veins. Halfdan. Pure creamy-yellow.

Helge. Light citron with pearl-colored centre.

Ingeborg. Pure white : flowers 5 inches deep, petals 2 inches wide.

Walhalla. Standards rosy-lavender; falls velvety claret-red.

Price. 20 cts. each; $\$ 2.00$ per doz.; $\$ 15.00$ per 100 .

\section{JAPANESE IRIS}

Six-Petaled Japanese Iris.

No.

Order by name or number.

4. Yomo-no-umi. A fine free-flowering early white.

5. Koki-no-iro. Rich royal-purple with white veinings.

8. Talheiraku. Ten petals, erimson-purple with yellow centre.

9. Oniga-shima. Rich royal-purple with many white veins.

20. Kuma-fuin. Silvery-white, with a broad border of magentalilac-veined with white.

21. Kumo-no-uye, Violet-blue with white veins and golden centre.

22. Sano-Watashi. White, with canary-yellow centre

26. Uchiu. Bright purple with crimson sheen.

35. Shishi-odori. Rich, velvety purple, shading to deep purple, golden-yellow centre.

36. Kumo-ubi. Pure light violet with golden centre and violetcolored standards.

4. Yoshimo. Very large flower; creamy-white, delicately veined with violet. o-tor-ige. Aniline-blue veined white with an effective

58. Mana-dsuru. A fine late flowering white.

58. Mana-dsuru. A fine late flowering white. bled with ultramarine-blue.

72. Uil-no-Hotaru. Bright violet-purple, shaded blue.

74. Renkaku. White, densely spotted and marbled with bright violet-blue.

91. Kan-ran. White, densely veined with deep violet.

94. Momochi-guma. Rich velvety-pansy-violet of a uniform shade throughout the flower.

107. Tokyo. A splendid pure white.

108. Shimosa. White ground, minutely and densely spotted throughout with bright violet-purple.

Price : Any of the above. 15 cts. each; $\$ 1.25$ per doz.; $\$ 8.00$ per 100 $\$ 70.00$ per 1000 . The set of 20 sorts for $\$ 2.00$.

\section{Three-Petaled Japanese Iris.}

No.

11.

12.

14.

dark violet-purple.
33. Kakujakuro. White

Order by name or number. dusted on.

43. Shi-un-ryo. Grayish-white, deeply and densely veined and suffused with violet.

55. Schuchiukwa. A showy variety, crimson-purple with white veins and white halo.

62. Misutmoshito. Violet-purple, marbled with purple.

67. Kigan=no-misao. A late lowering pure white.

70. Kimi-no-megumi. White, densely veined with purple; lateKimi-no-megumi. White, densely veined with purple; late-
flowering.

79. Shiratakl. Silvery-white, border of petals suffused with light Parma-violet.

77. Yayaura. White, occasionally marbled with light violet.

79. Kokirin. Rose-tinted white with purplish veins.

81. Sumida. White with faint violet veins.

82. Ari-Ake. Violet-purple, marbled with white

83. Washi-no-wo. Mottled purple with bright violet centre.

85. Ojochin. Light violet-purple, the latger veins white.

89. Oku-miyako. Light blue with white markings.

98. Tebotan. White ground, with prominent violet-blue veining.

97. Shiro-fungen. Light ground, suffused throughout with bluish-violet.

100. Yomo-zakuru. Light ground color, densely veined and suffused reddish-purple.

Price: Any of the above, 15 cts, each: 81.25 per doz,; $\$ 8.00$ per 100 ; 870.00 per 1000 . Set of 20 sorts, $\$ 2.00$.

Extra Choice Mixed Varieties. 81.00 per doz,; 86.00 per 100; $\$ 50.00$ per 1000 .

\section{Iris Pumila Hybrida.}

The Bride. The prettiest dwarf white Iris.

Cyanea, Rich royal purple, with blackish shadings.

Floribunda. (New.) Standards creamy-yellow, falls deeper, with greenish veins. 30 cts. each: $\$ 3.00$ per doz.

Excelsa. A beautiful clear yellow, shaded darker.

Schneekuppe. (New). A pure white of same form and approaching in size Iris Germanica. $30 \mathrm{cts}$. each; $\$ 3.00$ per doz. 85 cts. per doz.; $\$ 6.00$ per 100 ; except where noted.

\section{Various Types of Iris. Perdoz. Per 100}

Cristata

Ochroleuca (Gigantea). Grows to 5 feet high,

with white flowers

Ochroleuca (Gigantea) Aurea. Pale sulphur.

Pseudacorus

Sibirica

"Albo $2085 \quad 8600$

“ Orientalis

Spuria, Mrs. A. W. Tait
200

200

100

100

100

100

100

200
1500

1500

700

700

700

700

700

1500 
Iberis (Hardy Candytuft).

Corrafolia. 3-inch pots

Sempervirens. 4-inch pots

". Snowflake. 3-inch pots

Per doz. Per 100

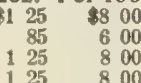

Inula (Flea Bane).

Ensifolia. 3-inch pots . . . . . . . . 125800

Glandulosa Grandiflora. 3-inch pots ..... 125800

Montana. 3-inch pots

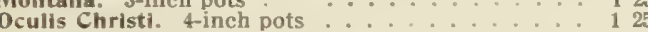

Incarvillea (Hardy Gloxinia).

Delavayi. Large, rose-colored, trumpet-shaped
flowers. Extra strong roots.

flowers. Extra strong roots
Grandiflora. An improvement on the above, the

flower being larger as well as brighter in color. . 125

800

Lavandula (Lavender).

Vera. $2^{1 / 4}$-inch pot

Linaria (Toad Flax).

Hepaticafolia, 3 -inch pots........... 1

1000

Liatris (Blazing Star, or Kansas Gay Feather).

Pycnostachya. 3-inch pots . . . . . . . . . 85
Scarlosa, 3-inch pots . . 85

Spicata. 3-inch pots.

5600

$\begin{array}{ll}6 & 00 \\ 6 & 00\end{array}$

600

Lindelofia.

Longifolia. 4-inch pots

800

Lithospermum (Gromwell).

Prostratum. 20 cents each; $\$ 2.00$ per dozen.

\section{Linum (Flax).}

Perenne. Blue and white. 3-inch pots

Flavum. 3-inch pots

Lobelia.

Strong pot-grown plants, not small native collected stock, such as is usually sold.

$\begin{array}{rr}\text { Per doz. Per } 100 \\ \quad \$ 085 & \$ 600 \\ 85 & 600\end{array}$

Cardinalis. 3-inch pots .

Syphilitica Hybrida. 3-inch pots

$85 \quad 600$

\section{Lupinus (Lupine).}

Polyphyllus Moerheimi. The most beautiful variety yet intro duced; a combination of light and dark shades of pink. 20 cents each; $\$ 2.00$ per dozen; $\$ 15.00$ per 100

Polyphyllus. Blue. Very strong roots, \$1.25 per doz.; $\$ 8.00$ per 100 Albus. Pure white, 1.50 per doz; 10.00 per 100.

$$
\text { Lychnis (Ragged Robin). }
$$

Chalcedonica. 3-inch pots

3-inch pots

$$
\because \quad \text { Carnea. 3-inch pots }
$$

Flore Plena. 3-inch pots

Haageana. 3-inch

Semperflorens Plenissima. 3-inch pots

Vespertina. Double white. 4-inch pots

Viscaria Splendens. 4-inch pots

Lysimachia (Loose-strife).

Per doz. Per 100 $085 \$ 800$ 85600 $85 \quad 600$ 1500

Ciliato 4-inch pots

Clethroides. 4-inch pot

Fortunel. $3 \frac{1}{2}$-inch pots

Nummularia. 3-inch pots

Punctata. 4-inch pots.

Lythrum (Rose Loose-strife).

Roseum Superbum. Strong . . . . . . . . 85

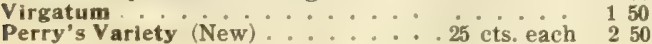

Myosotis (Forget-me-not).

Palustris Semperflorens, (Everblooming) ".

\section{Marshallia.}

600

600

600

600

600

1000

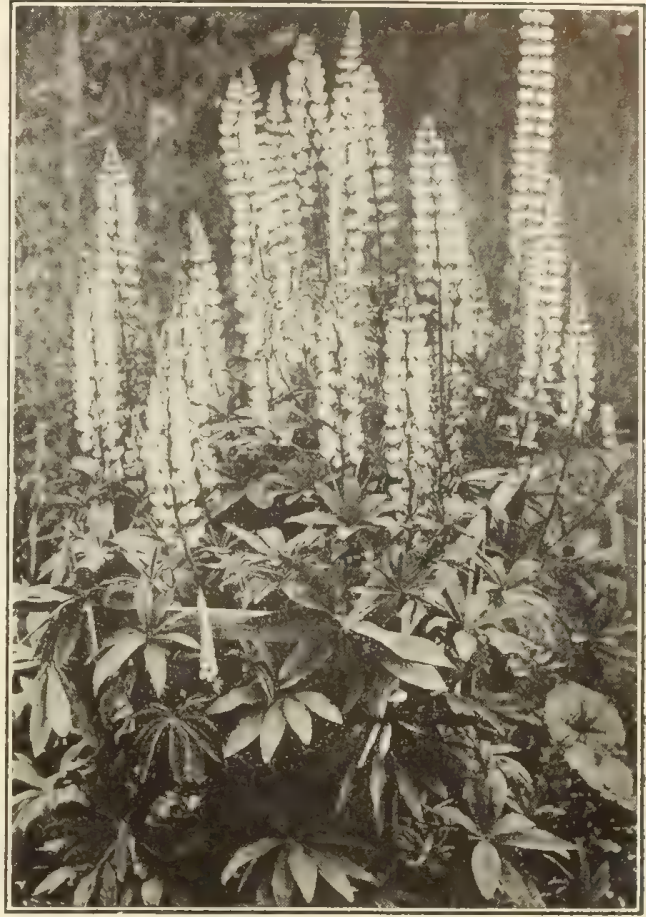

LUPINUS POLYPHYLLUS

Mentha (Mint).

Piperita. (Common Peppermint)

Rotundifolia Variegata

Spicata, or Virides. (Spearmint)

Per doz. Per 100

$\$ 060 \quad \$ 400$

60

Mertensia (Blue Bells).

Virginica. 3 -inch pots............ 125

Monarda (Horse Mint).

Didyma. 4-inch pots

Rosea 4-inch pots

Rosea, 4-inch pots.

Cambridge Scarlet. 4-inch" pots

Violacea (New) 4-inch pots

Fistulosa Alba. 4-inch pots

Nierembergia (Cup Flower).

Rivularis, 3-inch pots........... 1258800

Orobus (Bitter Vetch).

Vernus. 3-inch pots...

Lathyroides. 3-inch pots

$150-1000$

Ononis (Rest Harrow).

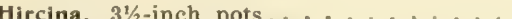

Enothera (Evening Primrose).

Fraseri. 3-inch pots..

Caspitosa. 3-inch pots ..

Missouriensis. 4-inch po
Pligrimi. 3-inch pots.

Pllgrimi. 3-inch pots

Speciosa Hybrida. 3-inch pots

Youngl. 3-inch pots

150

1000

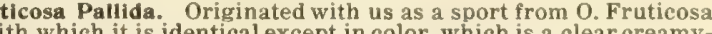
with which it is identical except in color, which is a clear creamywhite, entirely distinct. 20 cts, each; $\$ 2.00$ per doz.

Eldorado. The first double flowering Evening-Primrose, goldenyellow flowers, free and attractive. $20 \mathrm{cts}$. each; $\$ 2.00$ per doz. 


\section{Hardy Herbaceous Pæonies}

We offer a large stock of our own growing, strictly true to description, all in strong divisions with from 3 to 5 eyes.

Per doz. $100 \quad 1000$

Agnes Mary Kelway. Rose-white guard petals;

centre creamy-white.

Achille. Soft mauve-rose. changing to almost

Dure white

Andre Lasries. A fine tyrian rose; late. . .

Armandine Mechin. Semi-double deep red.

Alex. Verschaffelt. Bright reddish-violet

Anemonaflora Rubra. Dark crimson, anemone

type blooms .

Canari. Guard petals white, centre amber-white

changing to pure whit

Charlemagne, Large rose tinted white. . . .

Comte de Diesbach. Aniline-red, with lighter

shadings; narrow centre petals

Couronne d'Or. One of the finest late-flowering white varieties

Dragon. A fine large single dark-crimson Japanese variety

Duke of Wellington. Sulphur white. . . . .

Duc de Cazes. Guard petals tyrian-rose; centre rose-pink.

Duchesse de Nemours, Large sulphur-white.

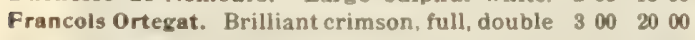

Fellx Crousse. Brilliant red; one of the finest. $450 \quad 3500$

Floral Treasure. Very large, pale lilac-rose. . $350 \quad 2500$

Festiva Maxima. Pure white, centre petals occa-

sionally tipped red. The most popular white

lor cutting

$200 \quad 150014000$

Grandiflora Rosea. Bricht pink shaded salmon $200 \quad 150014000$

Golden Harvest. Medium size; peach blossom

pink, creamy-white centre

Humel. Beautiful rose-pink; late

Humei Rosea. Large, pale rose: late

Marie Lemolne (Lemoine's). Extra large late flowering; ivory-white

Mme. Crousse. Purest white; very large . -

Mme. de Verneville. Sulphur-white, with car-

mine-tipped centre petals

Mons. Chas, Leveque. Large hydrangea pink

with lilac-white guard petals

Mons. Mallet. Tyrian-rose with salmon shadings in centre

Ne Plus Uitra. Violet-rose guard petals; centre mauve-rose, with lighter edges

nol. Solfino-red, with lighter centre . . 15010009000

Queen Victoria. A popular early white, extensively used for cutting

Reine des Fleurs. Violet-rose, lighter markings 200

Zoe Calot. White, suffused with delicate rose. $\begin{array}{llll}2 & 00 & 1500140 & 00\end{array}$

Paonies, Early Flowering. Per doz, Per 100

Officinalis (Mutabilis) Alba. Blush white .... \$1 $50 \$ \$ 1000$ Rosea. Soft bright pink... $150 \quad 1000$

Rubra. Crimson .......... 100700

Tenuifolia flore plena. Crimson........ 3002000

Paonies in Mixture. Per doz. $100 \quad 1000$

Double White

Pink.

\$0 $85 \$ 600 \$ 5000$

All Colors Mixed

$85 \quad 600 \quad 4000$

$85 \quad 500 \quad 3500$

\section{Tree Paeonies.}

We offer a collection of 12 distinct varieties; strong, 3-year-old plants, 75 cents each; $\$ 8.00$ per dozen.

\section{Papaver Nudicaule (Iceland Poppies).}

White, Yellow or Orange. 3-inch pots

Per doz. Per 100 $\$ 125 \$ 800$
8120
85

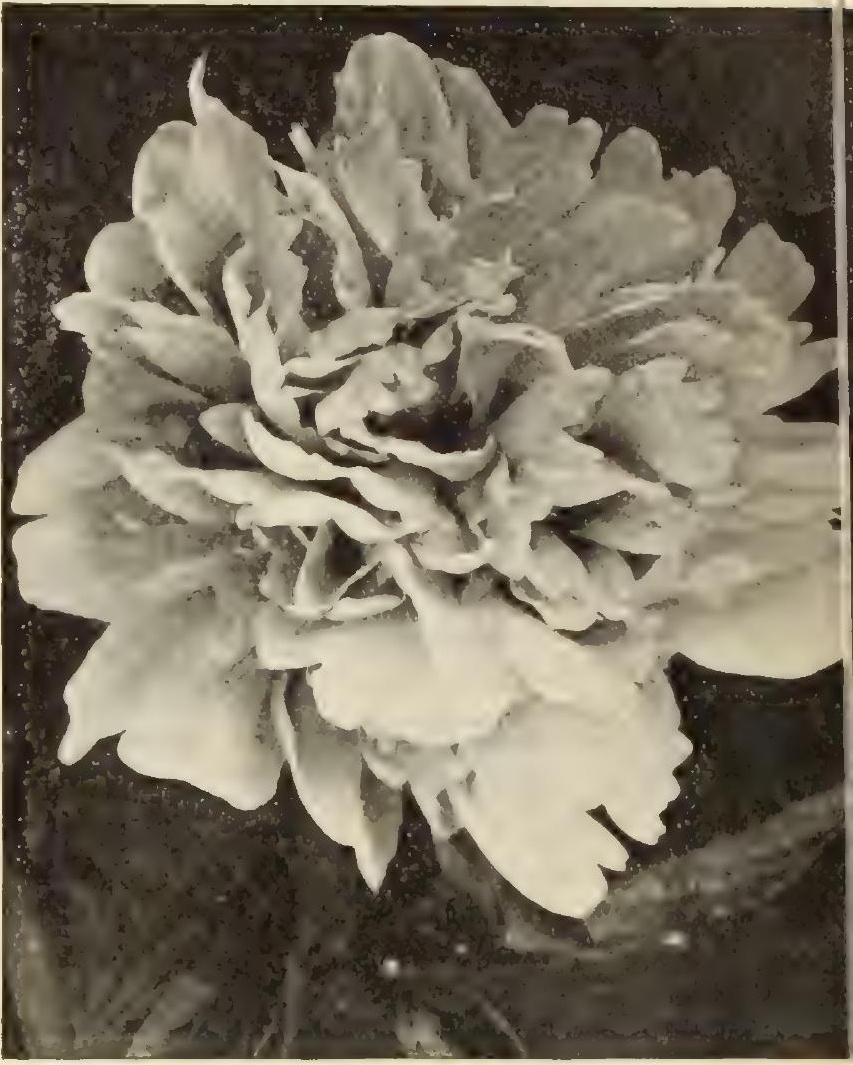

DOUBLE HERBACEOUS P.EONY

Papaver Orientale (Oriental Poppy).

It is not possible to satisfactorily transplant Oriental Poppies from the field in the spring. The stock which we offer is all one-year old field-grown, which was lifted and potted up into 3 and 4-inch pots during August and can be transplanted without any check.

Gollath. Brilliant fiery scarlet.

Mahogany. Dark crimson maroon.

Mrs. Perry. Salmon rose.

Trilby. Brilliant red, with dark spots.

$\$ 1.50$ per dozen; $\$ 10.00$ per 100.

Cholcest Mixed. Seedlings. 85 cents per dozen; 86,00 per 100 .

Pardanthus (Blackberry Lily). Per doz. Per 100 Sinensis. 4 -inch pots

$8085 \quad 8600$

\section{Pentstemon (Beard Tongue).}

Barbatus Torreyli. 4-inch pots ...... 100700

Diffusus, 4-inch pots .......... 100700

Digitalis, 4 -inch pots ........... 100700

Ovatus. 3-inch pots ........... 1007700

Pubescens. 4-inch pots .......... 100700

Smali. 4-inch pots ............. 100700

Gentianoides "Sensation." Gloxinia-like flowers in a variety of bright colors, including rose, cherry, crimson, purple, lilac, etc. For bedding they rival Phloxes, Petunias, etc. Not quite hardy. 3-inch pots. $\$ 1.25$ per doz.; $\$ 8.00$ per 100 .

Petasites (Coltsfoot). Per doz. Per 100 Japonicus Giganteus. Strong, 4-inch pots .... \$1 $25 \$ 800$

\section{Physalis.}

Franchetl (Chinese Lantern Plant). ....... 125 


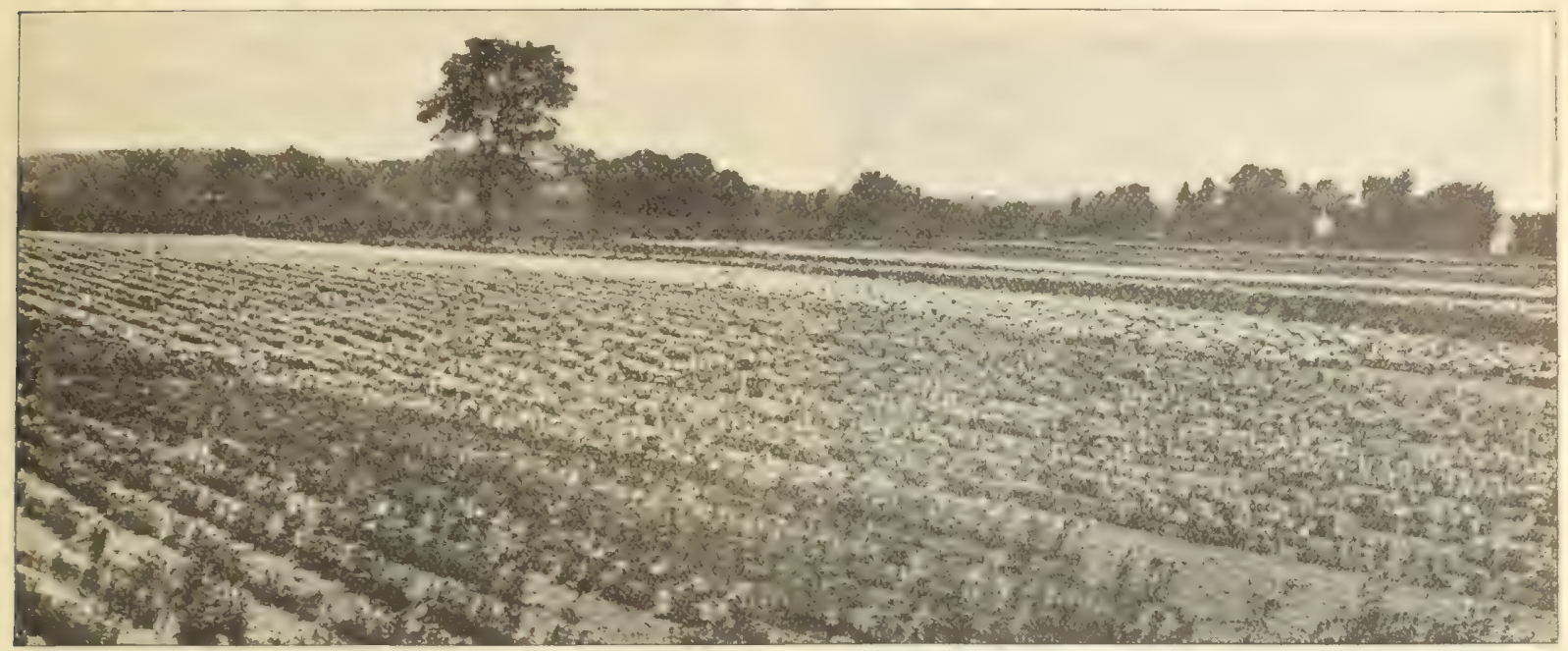

VIEW OF PART OF ONE OF OUR FIELDS OF HARDY PHLOXES

\section{Hardy Perennial Phloxes}

We are the largest growers of Perennial Phlox in the world, having this season over a half million field grown plants in stock.

The collection offered below embraces every known color in this gorgeous race of Summer flowering plants and we are prepared to furnish many of the rarer as well as the older standard varieties in large quantities at a low uniform price.

The plants we offer are all strong one-year-old field-grown, and will make'a fine display of flowers this season.

\section{New Varieties of Phlox}

Asia. One of the most valuable recent introductions, a delicate shade of mauve, with a crimson-carmine eye. $\$ 2.00$ per doz. $\$ 15.00$ per 100

Braga. Mauve-rose more or less suffused with salmon; large white eye, a distinct and pleasing color combination. $\$ 1.50$ per doz.; $\$ 10.00$ per $100 ; \$ 90.00$ per 1000 .

Europa. A white variety with very decided crimson-carmine eye, the individual flowers as well as the trusses are very large: entirely distinct. $\$ 2.00$ per doz.; $\$ 15.00$ per 100 .

Elizabeth Campbell. Very bright salmon-pink, with lighter shad. ings and dark crimson eye, an entirely new and much wanted shade in Phlox. \$1.25 per doz.; 88.00 per 100; $\$ 70.00$ per 1000 .

Frau Anton Buchner. The finest white variety yet introduced,

Frau Anton Buchner. The finest. White variety yet introduced, $\$ 1.25$ per doz.; $\$ 8.00$ per $100 ; \$ 70.00$ per 1000 .
Hervor. This is the finest variety of its color; a bright but soft rose-pink, with a large white eye. \$1.25 per doz.; \$8.00 per 100; $\$ 70.00$ per 1000 .

Rynstrom. An improved form of the popular variety Pantheon, fine for massing. of a Paul Neyron rose-color. $\$ 1.25$ per doz; $\$ 8.00$ per $100 ; \$ 70.00$ per 1000

Rosenberg. Bright reddish-violet, with blood-red eye, large truss and individual flowers as large as a silver dollar. $\$ 1.25$ per doz.; $\$ 8.00$ per $100 ; \$ 70.00$ per 1000 .

Widar. A splendid improvement on Edmond Rostand; in color, a light reddish-violet with very large white center, which intensifies the color. $\$ 1.25$ per doz.; $\$ 8.00$ per $100 ; \$ 70.00$ per 1000 .

\section{General Collection of Hardy Phlox}

Aglae Adanson (Medium). Snow-white, with red eye.

Albion (Medium). One of our own introductions; producing very large panicles of pure white flowers with a faint aniline-red eye. Antonin Mercie (Medium). Light ground color, upper half of each petal deeply suffused bluish-lilac, large white halo.

Bacchante (Tall). Tyrian rose with crimson-carmine eye.

Bacchante (Tall). Tyrian rose with crimson-carmine eye.

Bridesmaid (Tall). White, with large crimson-carmine centre.
Colibri (Tall). White, with crimson-carmine centre; very late.

Consul H. Trost Medium). Pure red, with bright French-purple eye.

Consul $H$. Trost (Medium). Pure red, with bright French-p
Champs Elyses (Dwarf). A very bright rosy magenta.

Coquelicot (Dwarf). A fine pure scarlet, with erimson-red eye. 85 cts. per doz.; $\$ 6.00$ per 100 .

Caran d'Ache (Medium). Geranium-red, with old rose shadings and white eye; very effective.

Danton (Medium). Scarlet, pure red eye.

De Miribel (Medium). White, suffused with bright rosy scarlet, red eye.

Diadem (Dwarf). A fine dwarf, pure white.

Edmond Rostand (Medium). Reddish violet, shading brighter

towards the centre, with an exceptionally large, white centre.

Eugene Danzanvillier (Tall). Lilac, shading white towards the

Eugene Danzanvillier (Tall
edges; large white centre.

Eclaireur (Tall). Brilliant rosy magenta, with large lighter halo.

Fruhlicht. Bright salmon-pink with white shadings.

George A. Strohlein (Medium). Bright scarlet, with crimson-red eye; does not bleach. $\$ 1.00$ per dozen; $\$ 7.00$ per 100

General Giovaninelli (Dwarf). Bright tyrian rose, with light shadings at the base of each petal, a pure red eye; very effective.

Goliath (Very tall). Rich carmine shading to a deeper centre.

Hermine (Dwarf). The dwarfest variety in our collection, never exceeding ten inches in height; pure white flowers of good size, early; unequalled for bordering; a perfect little gem.

Helena Vacaresco (Dwarf). Very large flowering dwarf, white.

H. O. Wijers (Tall). White, with bright crimson-carmine eye.
Henry Murger (Tall). White, crimson-carmine centre.

Henry Royer (Medium). Tyrian rose, with lighter shadings. Jeanne d'Arc (Tall). A good standard late white.

Kucken (Tall), Delicate pale rose-mauve with claret red eye.

Louise Abbema (Dwarf). Very large dwarf, pure white, of fine form.

Le Prophete (Dwarf). Bright violet-rose, large light halo and Le Prophete (Dwarf)

Mme. Paul Dutrie (Tall). A delicate lilac rose, reminding one of some of the beautiful soft pink Orchids.

Mozart (Tall). Ground color white, suffused salmon; anilinered eye.

Mrs. Jenkins (Tall). The best tall early white for massing.

Nana Corulea (Dwarf). A very free flowering light reddish-violet. Obergartner Wittig (Medium), Bright magenta, with crimson-carmine eye; large flower and truss; one of the best.

Professor Virchow (Medium). Bright carmine, overlaid with orange scarlet.

Pantheon (Tall). Bright carmine rose.

Prosper Henri (Dwarf). Pure white, with large decided eye of rosy magenta.

Pacha (Dwarf). Deep rose pink, suffused with solferino-red and carmine-purple eye.

R. P. Struthers (Tall). Rosy carmine, with claret-red eye, fine.

Sunshine (Dwarf). Large, aniline-red with crimson-red eye and light halo.

Selma (Tall). Large flower, pale rose mauve, with claret-red eye.

Siebold (Tall), Bright vermilion-red, overlaid with orange scarlet; crimson-red eye. 85 cts. per doz.; $\$ 6.00$ per 100.

Sarabande (Medium), Reddish-violet, with lighter shadings.

Vesuvius (Medium). One of our new seedlings; pure red, with bright purple eye; a dazzling color.

Von Lassburg (Medium). The purest white in cultivation, individual flowers larger than any other white.

Price. Any of the above General Collection, except where noted, 75 cts. per doz.; $\$ 5.00$ per $100 ; \$ 40.00$ per 1000 . 


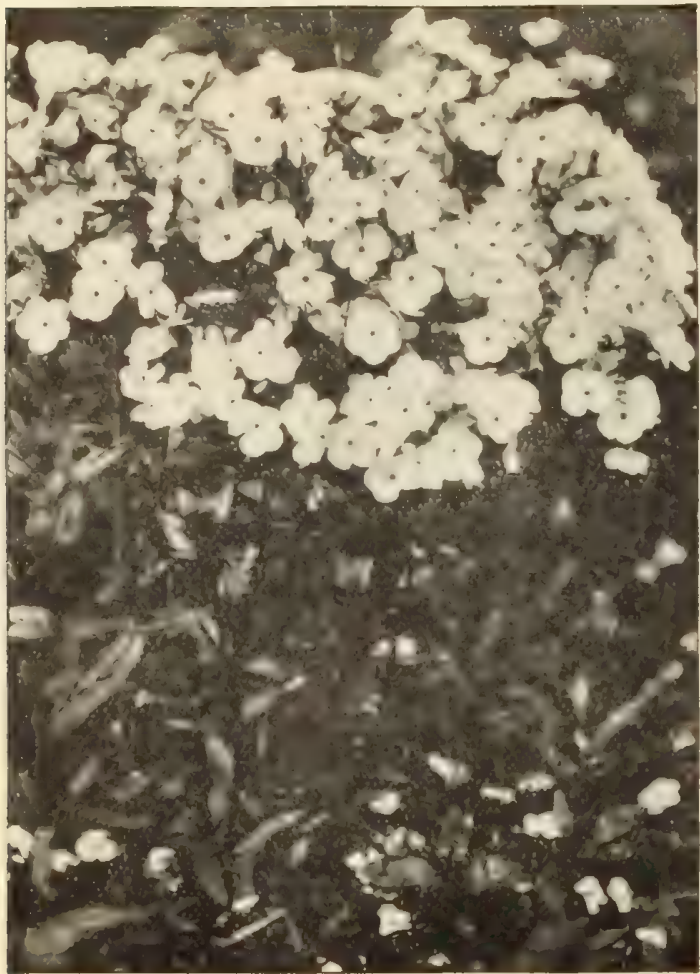

NEW HARDY PHLOX ARENDSI

Early Flowering Phlox (P. Suffuticosa).

Miss Lingard. The grand, free-flowering early white. Hercules. Bright rosy lilac.

Mrs. Dairymple. White shaded rose; scarlet eye.

Ninon. Deep rosy lilac.

$\$ 1.00$ per doz.; $\$ 7.00$ per 100.

\section{A New Race of Phloxes, P. Arendsi.}

At the great international exhibition held in London in May, 1912. where this new type of Phlox received an award of merit, no other new plant in the Hardy Perennial class attracted such great atten tion. This new type originated through the successful crossing of the early-flowering popular Phlox Divaricata Canadensis with the showy hardy herbaceous varieties of Phlox Decussata. The plants are of vigorous, branching habit, growing, according to the variety. from twelve to twenty-four inches high. Coming into flower during the latter part of May, they continue in good condition for nearly two months.

From a large number of varieties, the introducer has selected five of the most distinct sorts which we now offer for the first time.

Charlotte. Grows eighteen to twenty-four inches high. nowers very large, pale lilac shaded pink, with a prominent dark eye one of the best.

Grete. Plant of very branching habit, twenty inches high, producing great masses of medium-sized white flowers.

Helene. Of a beautiful lavender-blue color, similar to Divaricata Canadensis, shapely plant, fifteen to eighteen inches high.

Kathe. Stems loosely branched, about twenty inches high, flowers purplish-rose, with a dark eye, surrounded by a lighter halo.

Luise. A strong-growing variety, about two feet high, light lilac flowers with a carmine eye.

Price. 35 cts. each; $\$ 3.50$ per dozen. One each of the 5 varieties for $\$ 1.50$.

\section{New Phlox, Pilosa Splendens.}

A splendid companion to Phlox Divaricata Canadengis, growing from twelve to fifteen inches high and flowering at the same time. but producing great masses of brilliant rosy-carmine flowers. An excellent border plant. 25 ets, each; $\$ 2.50$ per dozen.

Phlox Subulata.

(Moss Pinks or Mountain Pinks.)

Alba. White.

Bridesmaid. Purplish tinted white, with deeper eye.

Lilacina. Light lilac.

Nelsonl. Pure white.

Rosea. Bright rose.

75 cts. per doz.; 45.00 per $100 ; 40.00$ per 1000

\section{Phlox-Various Types.}

Divaricata Alba Grandiflora. New large, white-flow-

ered form Divaricata Canadensis. 3-inch pots. ...... 85800 Divaricata Laphaml (Perry's Variety). New largeflowered Maculata, 4-inch pots ............. 858600 Ovata Caroliniana. 3-inch pots ........ 100700

Physostegia (False Dragon-head).

One of the most beautiful of our midsummer flowering perennials. A most useful plant for cutting, especially the pink form.

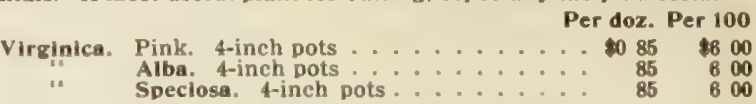

\section{Two Splendid Hardy Pinks.}

\section{Dianthus Plumarius.}

Delicata. A soft colored variety, a most delicate silvery mauve peculiar to some of the Orchids.

Gloriosa. A pleasing delicate shade of lilac mauve with deeply fringed flowers.

20 cts. each: $\$ 2.00$ per doz.; $\$ 15.00$ per 100.

\section{Hardy Garden Pinks.}

Diamond. Fine pure white.

Elsie. Bricht rose, with maroon centre.

Excelsior. Light rosy pink

Her Majesty. Pure white.

Homer. Rosy-red, with dark centre

Jullette. White, laced crimson.

Snow. A fine pure white.

White Reserve. Everblooming pure white. 81.00 per doz.; 87.00 per 100.

\section{Hardy Pinks in Mixture.}

Grown from a very select strain of seed which should produce a good percentage of double flowers, but even those which come single are very pretty and preferred by some to the double forms. 85 cts. per doz.; 86.00 per 100 .

Hardy Mule Pink (Dianthus hybridus)

Fettes Mount. A charming variety completely covered in June with very attractive soft rosy-pink flowers, 85 cts, Der doz. \$6.00 per 100 .

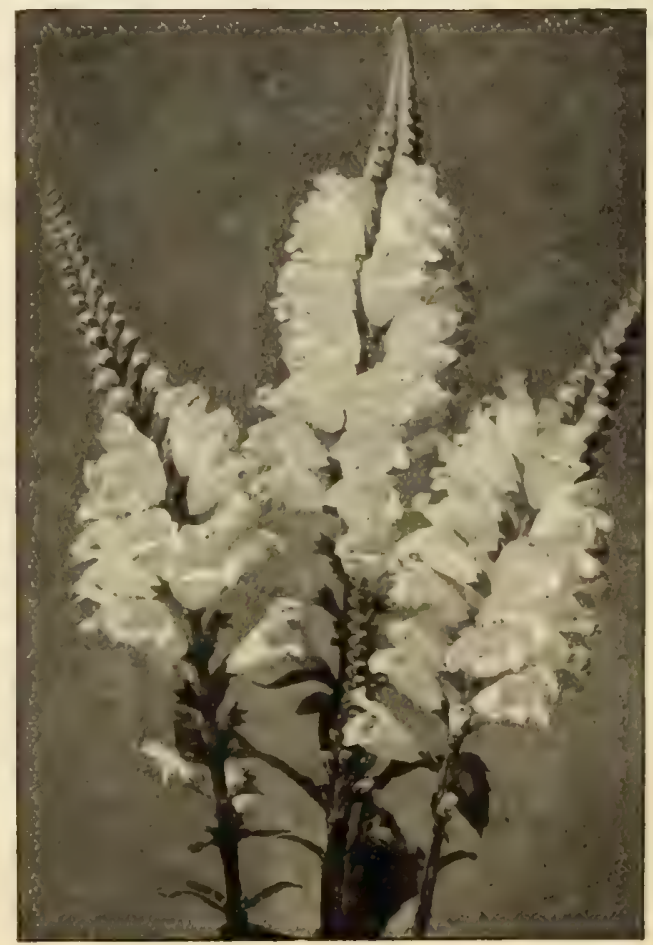

PHYSOSTEGIA 


\section{Platycodon (Japanese Bell Flower).}

Marlesi Ser doz. Per 100

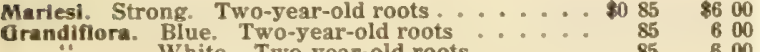

White, Two-year-old roots...... 85

Plumbago (Lead Wort.)

Larpentre, Strong, 3-inch pots ....... 100700

Podophyllum (May Apple or Mandrake).

Peltatum. 4-inch pots ............ 100

Polemonium (Jacob's Ladder).

Reptans, 3-inch pots

Reptans. 3-inch pots
Richardsonil Alba. 3-inch pots

$100 \quad 700$

Polygonatum (Solomon's Seal).

Majus. 3-inch pots.

\section{Potentilla (Cinquefoil).}

Formosum. Single, rosy-red . .

Miss Wilmot (New). Single pretty cerise flowers

Plantil. I

Pyrenaica. Single golden yellow

Pyrenalca, Single golden yellow

Wm. Rollison. Bright vermilion, double

800

Polygonum ( Knot-weed).

Brunenis. 3-inch pots

Cuspidatum. Strong clumps

Compactum. Strong, 3-inch pots

\section{Primulas, Various Types.}

Acaulis Alba Plena. Double white

"Carulea. Purplish blue

“ Croussei Plena. Double purplish red

Auricula. Choice mixed

Cashmeriana

Alba .

Veris. In choice mixture

Giant yellow

Vulgaris (Hardy English Primrose)

\section{Primula Cortusoides Sieboldi.}

These are not so well known as they deserve; they are of free vigorous growth, and can be flowered in pots in early spring, and respond quickly to forcing when placed in a temperature of 50 degrees, forming pretty pot plants in a short time, making excellent window plants, which meet with ready sale when in bloom.

We offer six distinct varieties, from pure white to the deepest rose in color. $\$ 1.50$ per doz,; $\$ 10.00$ per 100 .

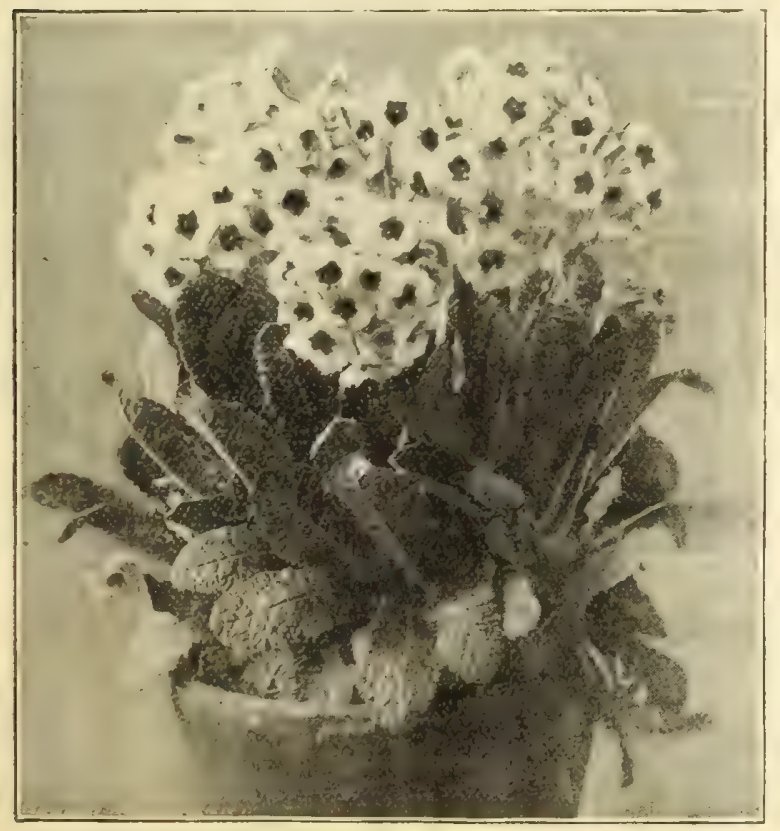

PRIMULA VERIS SUPERBA

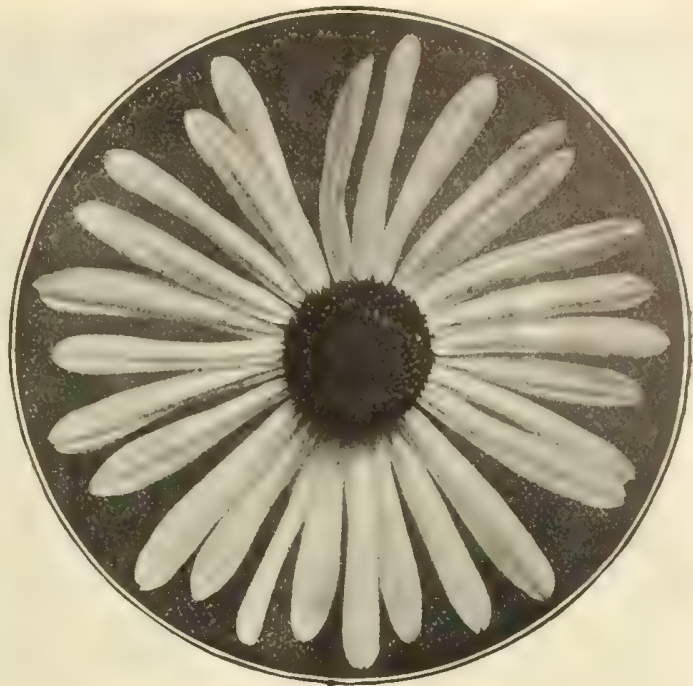

PYRETHRUM ULIGINOSUM STELLATA

Prunella (Self Heal).

Grandiflora. 4-inch pots. Per doz. Per 100 Grandiflora. 4-inch pots............. $\$ 100 \$ \$ 100$
Incisa. 4-inch pots

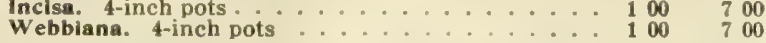

Pulmonaria (Lungwort or Bethlehem Sage).

Officinalis Rosea. . . . . . . . . . 1258800 Saccharata Maculata. A beautiful foliage plant. Strong, 4-inch pots, $\$ 1.50$ per doz.; $\$ 10.00$ per 100

Angustifolia Azurea (New). $35 \mathrm{cts}$. each; $\$ 3.50$ per doz.

\section{Pyrethrum.}

Hybridum, FI. PI. A nice lot of 5-inch pots, in Double White, Pink and Crimson. $\$ 2.50$ per doz.; $\$ 20.00$ per 100

Hybridum. Seedlings, 3-inch pots .

Per doz. Per 100

Uliginosum (Giant Daisu). 4-inch pots

$\$ 100 \quad \$ 700$

Pyrethrum Uliginosum Stellata.

A variety which originated in our nursery. It is a greatly improved form with long, narrow petals, forming a graceful and refined flower. The best and most useful Daisy for cutting during August and September. $\$ 1.50$ per doz; $\$ 10.00$ per 100.

Ranunculus (Buttercup).

Acris Flore Plena. 3-inch pots

Aconitifolia Flore Plena. 3-inch pots

Repens, fl. pl. 3-inch pots

Speciosus fl. Dl.

$\begin{array}{rrr}\text { Per doz. } & \text { Per } 100 \\ \therefore \quad & 125 & 8800 \\ \therefore & 125 & 800 \\ \therefore \quad & 85 & 600 \\ \therefore \quad 100 & 700 \\ \therefore \quad & 100 & 700\end{array}$

Rheum (Ornamental Rhubarb).

Palmatum Tanghuticum. Strong

Virginica.

$$
\text { Rhexia (Meadow Beauty). }
$$

\section{Rehmannia.}

Angulata. 31/2-inch pots

\section{Rodgersia.}

Podophylla. Strong . 35 cts. each
Tabularis (new). Strong. 35 .

\section{Romneya Coulteri.}

(California Tree, or Matilija Poppy.)

While hardy as far north as Philadelphia, this must be planted in a well-drained, sheltered position. The flowers are white, six inches and over in diameter, and of a peculiarly delicate texture, the petals somewhat transparent, yet enduring in a good state for several days. Strong plants, 50 cts. each.

\section{Rosemary (Rosmarinus Officinale).}

Good plants in 3-inch pots. 


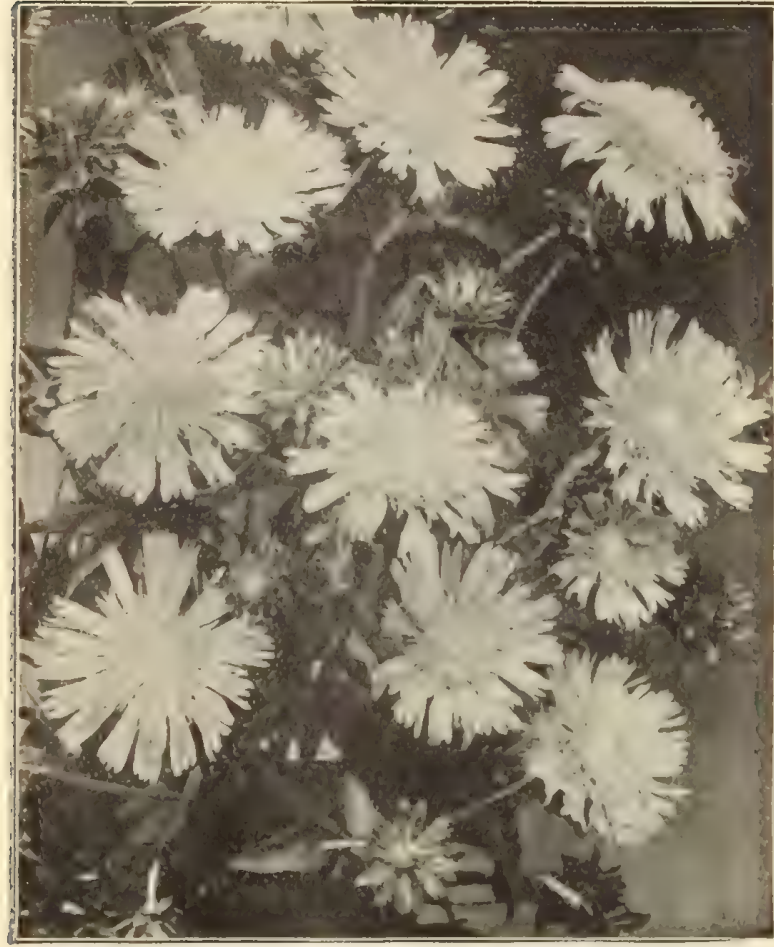

STOKrsia CYANEA (Cornflower Aster)

Rudbeckia (Cone Flower).

Fulgida. 4-inch pots

Golden Glow. 4-inch pots

Maxima. 4-inch pots

Newmani. Strong. $3 \frac{1}{2}$-inch pots

Nitida, Autumn Sun. Bright primrose-yellow

Purpurea (Giant Purple Cone Flower). Strong 3-inch pots

Sub-Tomentosa. 4-inch pots

Rays of Gold. Refined form of the popular Golden Glow, the flowers have narrower petals, full to the centre, forming a perfect ball of pold ".". ".

Trllola. 31/2-inch pots

\section{Salvia (Sage).}

Azurea. Strong, 4-inch pots

Argentea. Strong, 4 -inch pots

Pitcheri. Strong, $3 \frac{1}{2}$-inch pots

Pratensis. Strong, 4-inch pots

Sctareau. Strong, 3-inch pots

Sclareau. Strong, 3-inch pots 0 -

Per doz. Per 100 $8100 \$ 700$ 100 $100 \quad 700$ 00700 $100 \quad 700$ $100 \quad 700$

00

Santolina (Lavender Cotton).

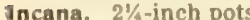

Chamacyparissus. $2 \frac{1}{4}$-inch pots

\section{Saponaria (Soap-wort)}

Caucasica Flora Plena. 4-inch pots

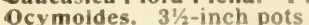

Satureia (Winter Savory)

Montana. 4-inch pots

Saxifraga (Alpine Varieties)

Pyramidalis. 3-inch pots

Sarmentosa. 3-inch pots

Umbrosa. 3-inch pots

Peltatum. 4-inch pots

\section{Saxifraga (Megasea)}

Brilliant. Crimson purple.

Cordifolia. Light rose

Orbiculare. Deep rose

Purpurea. Deep purple

Solendens. Rosy crimson

Splendens. Rosy crim
Speciosa. Rosy pink.

Speciosa. Rosy

Scabiosa (Blue Bonnet).

Caucasica. $3^{1 / 1}$-inch pots

Alba. 31/2-inch pots

Japonica. 3-inch pots

$$
\text { Scutellaria (Skull Cap). }
$$

Calestina. 3-inch pots

Sedum (Stonecrop).

Per doz. Per100

Acre. 4-inch pots ............. \$0 $85 \$ 600$

Album, Divisions, 4-inch pots ......... $85-600$

Ewersil. 4-inch pots........ 100

Japonica Macrophylla. 4-inch pots

Kamtschaticum. 3-inch pots

Variegatum. 3-inch pots

Lyaucum. 3-inch pots

Maximum Atropurpurea. 31/2-inch pots

Middendorfiana. 3-inch pots

Sexangulare. 4-inch pots

Sleboldl. 3-inch pots

Spectabilis. Strong $31 / 3$-inch pots

Spectabilis Brilliant (new). The brightest of the up

right growing sorts

Spurium. 4-inch pots

"Coccineum." 4-inch pots"

Stahll. 4-inch pots

Stolonifera, 3-inch pots

\section{Sempervivum (House Leek).}

Six best hardy varieties

Senecio (Groundsel)

Clivorum. Strong plants

Veitchianus. Strong
Wilsonianus. Strong

\section{Shortia.}

Gaiscifolia 3-inch pots

\section{Silene (Campion, Catchfly).}

Alpestris. $3 \frac{1}{2}$-inch pots

Schafta, $31 / 2$-inch pots

\section{Silphium (Rosin Plant).}

Perfoliatum. 4-inch pots............ 12

Sisyrinchium (Blue-eyed Grass).

Bermudianum. 3-inch pots

Smilacina (False Solomon's Seal).

Racemosa. Strong, 3-inch pots ..........

\section{Solidago (Golden Rod).}

Altissima. 4-inch pots

Cangdensts. 4-inch pots

Golden Wings (new)

Rigidus. 3-inch pots

Shortia. 4-inch pots

Virgaurea Nana. 4-inch pots

Spigelia (Carolina or Indian Pink).

Marllandica. 3-inch pots. 25 cts. each; $\$ 2.50$ per doz.

\section{Spirza.}

Aruncus. Clumps.

Chinensis. 4-inch pots

Fllipendulina Flore Plena. $3 \frac{1}{2}$-inch pots

Gigantea or Kamtschatica. $3 \frac{1}{2}$-inch pots

Paimata. 91/2-inch pots

$\begin{array}{ll}60 & 400 \\ 60 & 400\end{array}$

$125 \quad 800$

Oueen Alexandra. New pink. Clumps

Ulmarta Flore Plena. 4-inch Dots

Venusta. S-inch pots. 3-inch pots. inch Stachys (Woundwort).

Betonica Rosea. 31/2-inch pots . .

Eximia. 3-inch pots

Statice (Sea Lavender).

melini. 3-inch pots

Latifolia. 3-inch pots

Tartarica. 3-inch pots

Stenanthium (Mountain Feather Fleece).

Robustum. 35 cents each; $\$ 3.50$ per dozen.

Stokesia (Cornflower Aster).

Cyanea. Blue. 3-inch pots. Per 1000, $\$ 50.00$. $85 \quad 600$ Alba. 3-inch pots. White, Per $1000, \$ 50.00 \quad 85 \quad 600$ Sweet William. 
Tanacetum.

Per doz. Per 100

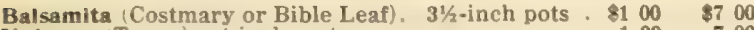

Vulgare (Tansy) 4-inch pots

\section{Thalictrum Orientalis.}

One of the best of the Meadow Rues. . It grows about two feet high, with finely cut glaucous blue foliage and branching heads of pure white flowers. 35 cents each; $\$ 3.50$ per dozen.

Thalictrum (Meadow Rue).

Aquilegifolium Album. 31/2-inch pots . . Per doz. Per 100

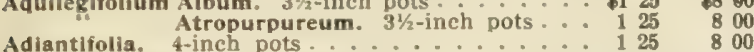

Dipterocarpum. New; 50 cts, each ....... 500

Flavum, 4-inch pots. .......... 125

Minus. 4-inch pots.

125800

Manus. 4-inch pots...

$125 \quad 800$

$\begin{array}{lll}1 & 25 & 800 \\ 1 & 25 & 800\end{array}$

\section{Thermopsis.}

Fabacea. 4-inch pots

Thymus (Thyme).

Carnosus, 3-inch pots

Serpyllum Album. 3-inch pots

Coccineum. 3-inch pots.

- plendens. 3-inch pots

80

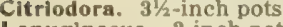

\section{Tiarella (Foam Flower).}

Purpurea Major. 3-inch pots . . . . . . . 125800

Tradescantia (Spiderwort).

VIrginica, $3^{1 / 2}$-inch pots............ $85 \quad 600$ Alba. 31/2-inch pots : $: \cdots$ Flore Plens. 31/2-inch pots... 1007700

Tricyrtis (Japanese Toad Lily).

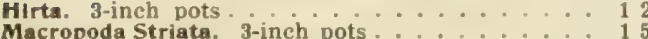

Trillium (Wood Lily, or Wake Robin).

Erectum. 3-inch pots

Grandiflorum. 3-inch pots .

Tritoma (Red-hot Poker, Flame Flower or Torch Lily).

Obelisque. Large spikes of saffron-yellow with brighter shadings: July and August: $31 / 3$ to 4 feet. $15 \mathrm{cts}$. each; $\$ 1.50$ per dozen.

Pfitzeri. (The Everblooming Flame Flower). In bloom from August to October with spikes from 3 to 4 feet high, and heads of Aloom of a rich orange-scarlet. $\$ 1.25$ per dozen; $\$ 8.00$ per 100 ; $\$ 75.00$ per 1000.

Quartiniana. Flowers late in May in spikes 10 to 12 inches long, orange red when first opening, the lower part changing to yellow when mature; $3 \frac{1 / 2}{\text { to }} 4$ feet. 35 cents each; 8.50 per dozen.

Tricolor. A charming small flowered sort, the buds at first cochineal-red, changing to canary-yellow, finally opening a sulphur-white, August to October; $2 \frac{1}{2}$ feet. $\$ 1.50$ per dozen.

Uvaria Grandiflora. The old-fashioned late-flowering sort; spikes

3 to 5 feet high, flowers rich ochre-red, passing to salmon-pink.

$\$ 1.25$ per dozen; $\$ 8.00$ per $100 ; \$ 75.00$ per 1000

\section{Trollius (Globe Flower).}

Europaus. 3-inch pots

Japonicus Excelsior. 3-inch pots

Orange Globe. 3-inch pots

Asiaticus Flore Crocea. 3-inch pots

Fire Globe. 3-inch pots.

Tunica.

Saxifraga. $3^{1 / 2}$-inch pots ............ 100

Per doz. Per 100 $\$ 150 \$ 1000$ $150 \quad 10.00$ $150 \quad 1000$

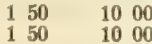

\section{Valeriana (Valerian).}

Coccinea. 4-inch pots.......... 125 Alba. 4-inch pots

Officinalis. 4-inch pots

\section{Verbascum (Mullein).}

Phoeniceum. 3-inch pots

\section{Veronica (Speedwell).}

Amethystina. $3 \frac{1}{2}$-inch pots

Incana. 3-inch pot

Longifolia Subsessilis. $3 \frac{1}{2}$-inch pots . . . 100

Maritima. $3 \frac{1 / 2}{2}$-inch pots............

Pectinata. 3-inch pots.....

Rosea. $3 \frac{1}{2}$-inch pots.

Repans, $3-1 / 2$ inch pots

Spicata. $3 \frac{1}{2}-$-inch pots

Alba. 3-inch pots

Virginica. Alba, 3 -inch pots

Arkansana.

Vernonia (Iron Weed).

Per doz. Per 100

New Hardy Vinca.

Vinca Minor Aurea.

A pretty yellow variegated form of the hardy Vinca Minor which is so extensively used as a ground cover especially in shaded places Where grass will not grow. for this purpose, particularly so as the foliage is much larger than in the type and irregularly margined and marbled with yellow.

It also should prove valuable for use in window boxes particularly for winter use in connection with Boxwoods and other Evergreen plants. $\$ 1.50$ per dozen; $\$ 10.00$ per 100 .

\section{Vinca Minor Argenta Variegata.}

A pretty silver variegated variety and a companion plant to the above. $\$ 1.50$ per dozen; $\$ 10.00$ per 100 .

Vinca (Periwinkle or Trailing Myrtle).

Minor. Strong bushy plants in 3 -inch pots. 85 cents per dozen; $\$ 6.00$ per $100 ; \$ 50.00$ per 1000

Vincetoxicum (Mosquito Plant).

Japonicum. 4-inch pots

Per doz. Per 100 $\$ 125 \$ 800$

Hardy Violets.

Pedata (Bird's Foot Violet). 21/4-inch pots Bicolor, 2\%-inch pots

Blanda. Sweet White Violet. 3-inch" pots Double Russian Blue, 3-inch pots.

$\begin{array}{rl}60 & 400 \\ 125 & 800 \\ 85 & 600 \\ 85 & 600\end{array}$

\section{Viola Cornuta Purpurea or G. Wermig.}

A variety of the Tufted Pansy which, in general appearance, so closely resembles the Princess of Wales Violet as to make it a splendid substitute for the latter during the summer month when they are not to be had. It is one of the popular flowers in Covent Garden Market, London, where thousands of bunches are sold daily. It will do equally well in the cooler parts of our country if planted in cool soil in a partially shaded position. $2 \%$-inch pots, $85 \mathrm{cts}$. per dozen; $\$ 6.00$ per 100

\section{Viola Cornuta (Tufted Pansies).} Admiration. Soft purplish-lilac with dark blotch . \$ $\$ 60 \quad \$ 400$ Lutea Splendens. Rich golden yellow..... $60 \quad 400$ Papilio. Violet purple, dark eye. . . . 60
White Perfection. A fine white

Wallflower. 


\section{CHOICE HARDY SHRUBS}

46 NOTE-All prices Include boxes, packing and delivery to any Express, Freight or Steamboat Line In Philadeiphia. Ta

Hardy Azaleas for Out-door Planting.

Mollis. A splendid lot of mixed seedlings giving a wide range of colors. This season our stock is of exceptional quality, bushy plants, 12 to 15 inches high. \$4.50 per doz, \$35.00 per 100 .

Anthony Koster. A large-flowered form of Mollis, with intense golden-orange flowers, 15 to 18 inches high: bushy. $75 \mathrm{cts}$, each; 7.50 per dozen.

J. C. Van Tol. A brilliant red form of Mollis, with very large flow ers; bushy; 15 to 18 inches high. 75 cts. each; 87.50 per doz.

Pontica or Hardy Ghent. A favorite variety to plant in connection with Rhododendrons; fine bushy plants 15 to 18 inches high, in choicest mixture. 60 cts. each; $\$ 6.50$ per doz.; $\$ 50.00$ per 100 .

Pontica Coccinea Speciosa. Brilliant reddish-salmon, with fieryred shadings. $75 \mathrm{cts}$. each; $\$ 7.50$ per doz.

Pontica Bouquet de Flore. Pleasing soft salmon-rose, semi-double. 75 cts. each; 87.50 per doz.

Pontica Davisil. The finest white, very floriferous. 75 cts, each $\$ 7.50$ per doz.

Pontica Nancy Waterer. A pleasing shade of Indian-yellow. 75 cts. each; $\$ 7.50$ per doz.

\section{Japanese Azaleas for Garden Decoration}

Amcens. Small, rosy-crimson flowers, almost evergreen, very floriferous bushy plants, 8 to 10 inches high. 4.50 per doz. 895.00 Der 100 .

Hinodegiri. Small, brilliant, fiery-red flowers in great masses. Splendid bushy plants, 11.00 each: 10.00 per doz.; 85.00 per 100 .

Yodogama. Entirely distinct, producing masses of semi-double lavender-pink flowers. Strong bushy plants, 18 to 20 inches high. $\$ 1.00$ each; 810.00 per doz.; 875.00 per 100

Japonica Aibs or Ledifolla Aibs. Large, pure white flowers, similar to the well-known Azalea Indica Alba, very free flowering and perfectly hardy in this latitude. Bushy, heavy plants, 15 to 18 inches high, $\$ 1.25$ each.

\section{Andromedas.}

Pretty evergreen shrubs, producing Lily of the Valley-like sprays of white flowers.

Florlbunda. Bushy plants, 15 inches high Japonica. Bushy plants, 15 inches high

Each Per doz. $8100 \$ 1000$

\section{New Buddleyas.}

Variabilis Veitchiana. Spikes of flowers 18 to 20 inches long of violet-mauve with yellow centre. Strong pot-krown plants, 20 ets. each; $\$ 2.00$ per doz.; $\$ 15.00$ per 100.

Veitchiana Magnifica. Deep rose purple with orange-yehlow cen tre. 20 cts, each; 2.00 per doz.; $\$ 15.00$ per 100

\section{Callunas and Ericas.}

Hardy Heather and Heath.

Calluna Vulgaris. True Scotch heather. Alba. True white Scotch heather. Alporti. A vigorous rosy carmine form. Elegantissima. An elegant white variety.

Erica Cinerea. Large rose-colored flower bells.

Mediterranea Hybrida. Nodding rose-colored flowers in very

early spring: fine for forcing.

Vagans Alba Cornish Heath. Produces upright clusters of flesh-pink flower

Vagans Rubra. A rosy.-red flowered form.

Bruckenthalia Spiculifolla. Produces delicate light pink heads of flowers in early June.

35 cts, each: 13.50 per doz: 25.00 per 100.

We will supply one each of this interesting collection for \$2.50.

Daphne Cneorum (Garland Flower)

A splendid lot of strong pot-grown plants from $41 / 2$-inch pots. 40 cts, each: 4.00 per doz.

\section{Daphne Fioniana.}

A valuable dwarf Shrub, forming almost spherical bushes about 18 inches high, covered during the latter part of May and early June with masses of small, attractive lilac-tinted white flowers, and continuing in flower off and on all summer and fall. Strong plants, 1.00 each.

\section{Hydrangea Arborescens Grandiflora.} (The Snowball Hydrangea).

This magnificent, perfectly hardy, American Shrub is the very finest addition to this class of plants in many a year. The snowfinest addition to this class of plants in many a year. The snowearly June until late August, makes it a valuable acquisition in any garden. Strong 2-year-old plants, 24 to 30 inches high, 25 cts. each; $\$ 2.50$ per doz.; $\$ 20.00$ per 100 .

\section{Hydrangea Paniculata Grandiflora.} \begin{tabular}{l} 
Bush-Plants. Strong, 24 to 30 inches high.... 150 \\
Tree-Shaped or Standards. \\
\hline
\end{tabular}

\section{Kalmia Latifolia.}

A fine lot of cultivated bushy plants, 18 to 24 inches high. 75 cts. each; $\$ 7.50$ per doz; 860.00 per 100 .

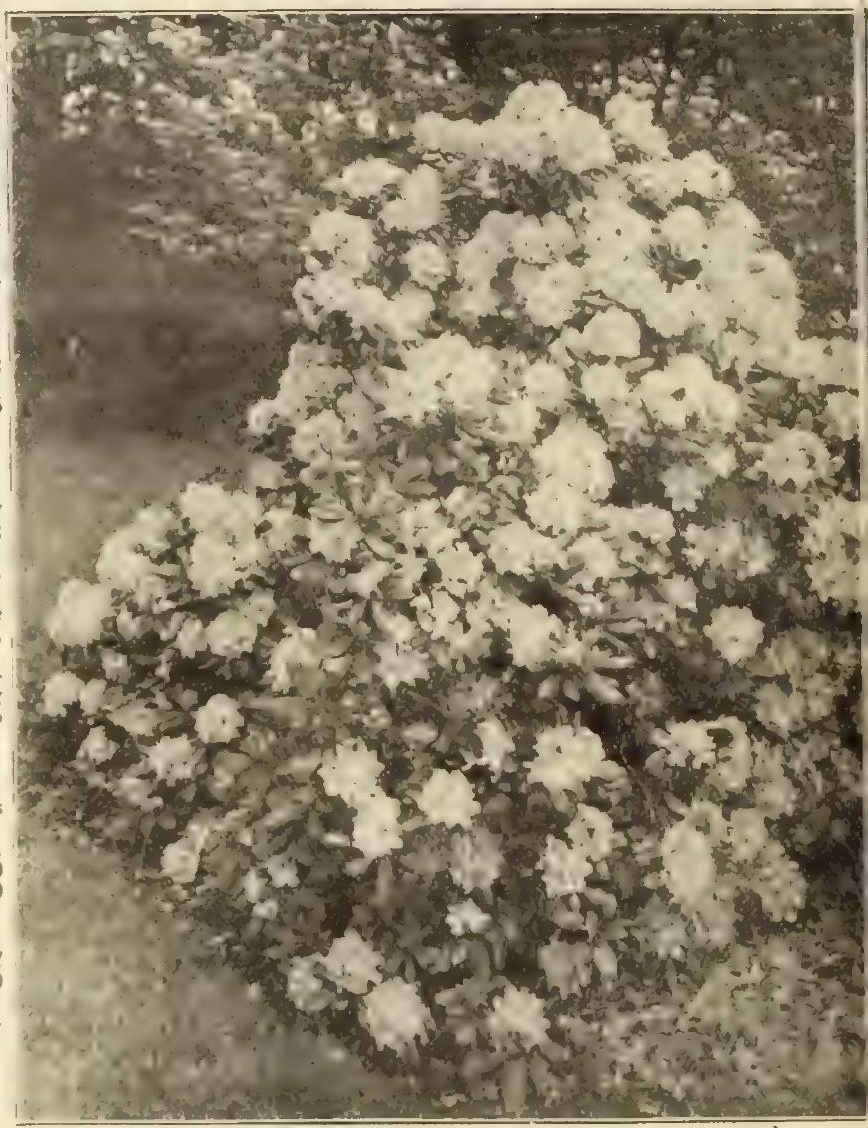

HARDY RHODODENDRON

Japanese Maples (Splendid Pot-Grown Plants). Per In. Pots In. High Each Doz. Polymorohum Atropurpureum . . . . 4 6 to $10 \quad \$ 040 \quad 8400$ Atrop. Dissectum 1000

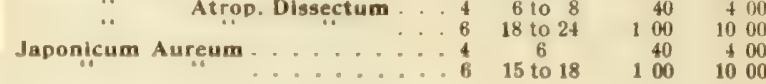

\section{Magnolias.}

Grandiflora. Pot-grown, 2 feet high

Alba Superba. Bushy plants, 8 feet high

Conspicua. Bushy ptants, 3 feet high

Microphylia. Pot-grown, 15 to 18

Kobus. Pot-grown, 2 feet high

Purpurea. Pot-grown, 2 feet high

Soulangeana. Strong plants, 5 feet bigh

Lennei. Strong plants, 3 feet high

Stellata. Bushy plants, 2 feet high

Trioetals. Pot-grown, 18 inches high.

Each

$\$ 035$

200

250

85
85

\section{Hardy Rhododendrons.}

We offer below but a limited list of hybrid varieties, which, however, is selected from the hardiest sorts of the Catawbiensis type.

Abraham Lincoln. Lively purplish-red.

Album elegans. A fine white.

Caractacus. Purolish crimson.

Catawbiensis alba. Pretty blush.

Arandiflorum. Soft violet mauve.

Chas, Dickens. Dark purplish crimson.

Delicatissima. Blush white.

Everestianum. Light rosy lilac.

General Grant. Aniline red.

Kettledrum, Crimson.

Parsons Grandiflorum. Rosy purple.

Roseum elegans. Bright rosy lilac.

We can furnish any of the above in strong, bushy plants, well sel with buds in the following sizes:
Height
2 to 18 in., according to habit of growth 80 Each
15 to 24
$\$ 075$
Doz. $\quad 100$
18 to 30
200
$2000 \quad 15000$ 


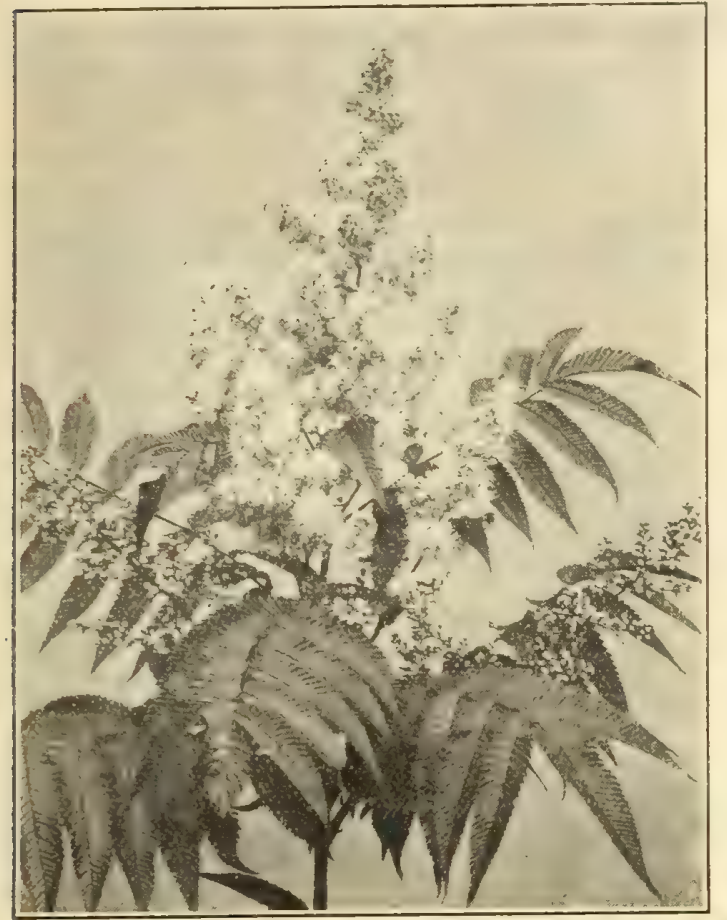

SPIR.EA SORBIFOLIA STELLJPEDA

\section{Rhododendron Punctatum.}

A distinct native species of compact spreading habit, splendid for exposed positions, being absolutely hardy, producing masses of medium sized purplish-rose colored flowers. $75 \mathrm{cts}$ each.

\section{Golden Variegated Privet.}

(Ligustrum Ovalifolium Aureum.)

A fine lot of bushy plants of this useful, ornamental, golden variegated shrub, 18 inches high. $\$ 2.00$ per doz.; $\$ 15.00$ per 100 .

\section{New Spiraa Bumaldi "Walluf."}

A splendid improvement on Anthony Waterer, being of a much richer, brighter crimson. Strong plants, $20 \mathrm{cts}$. each; $\$ 2.00$ per doz.

\section{New Spirza Sorbifolia Stellipeda.}

A splendid improvement on the old Mountain Ash-leaved Spiræa with which it is identical, except that the white flowers are produced in immense pyramidal panicles, frequently ten inches wide by fifteen inches high; these, backed with the bright green ferny foliage, appear like large bouquets of bloom. Flowers during July and August. 30 cts. each; $\$ 3.00$ per dozen.

\section{New Viburnum Carlesi.}

A Japanese variety of recent discovery, bearing large corymbs of sweet-scented white flowers, resembling somewhat in shape a Bouvardia. The plant is of bushy habit and is a most valuable addition to the family. Strong pot-grown plants, 50 cts. each.

\section{HEDE PLANT}

Althea (Rose of Sharon).

We have a large stock of very heavy 4-year-old plants which were cut back severely last spring and transplanted, and which are now in elegant condition for planting; 36 inches high; all colors. $\$ 10.00$ per 100; $\$ 85.00$ per 1000 .

\section{Berberis Thunbergii.}

18 to 24 inches high, bushy. $\$ 1.75$ per doz.; $\$ 12.00$ per 100 .

\section{Boxwood Edging.}

Bushy plants, 4 to 6 inches high. $\$ 5.00$ per $100 ; \$ 45.00$ per 1000 .

California Privet Per 100 Per 1000 1-year-old, 18 to 24 inches high, heavy $\ldots \ldots \ldots * 250 \quad \$ 2000$

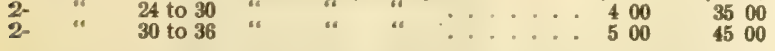

\section{Rosa Rugosa (Ramanas Rose).}

Both the red and white-flowering forms of these beautiful Roses are fast becoming popular as hedge plants. Strong, 2-year old plants. $\$ 2.00$ per dozen; $\$ 15.00$ per 100 .

\section{General Collection of CHOICE HARDY SHRUBS}

Abelia Chinensis Grandiflorum

Althea Admiral Dewey Alba Plena

Atropurpurea Plena

Coerulea Plena

Duchesse de Brabant Grandiflora Superba Jeanne D'Arc

Purpurea Folia Variegata Totus Albus.

Violacea, semi-plena.

Amorpha Fruticosa

Aralia Pentaphylla

$$
\text { Spinosa }
$$

Baccharis Halimifolia

Berberis Thunbergii Vulgaris Purpurea

Buddleya Variabilis Veitchiana

Calycanthus Floridus

Cephalanthus Occidentalis

Corchorus Argentea Variegata Japonica, fl. pl.

Cornus Alba Sibirica.

$$
\begin{aligned}
& \text { Mascula. } \\
& \text { Sanguinea }
\end{aligned}
$$

Crataegus, Oxyacantha Alba, plena Coccinea, plena.

Desmodium Penduliflorum Rosea, plena

Deutzia Candidissima, plena

$$
\begin{aligned}
& \text { Crenata Rosea, plena } \\
& \text { - Gracilis } \\
& \text { “ Lemoinei } \\
& \text { - Pride of Rochester } \\
& \text { Scabra }
\end{aligned}
$$

Eleagnus Longipes

Euonymus Europæus

Exochorda Grandiflora

Forsythia Fortunei

$$
\text { Viridissima }
$$

Hydrangeas. (See opposite page

Lonicera Fragrantissima.

$$
\text { „1cera Gragrantissima. }
$$

Ligustrum Regelianum

Philadelphus Boule d'Argent

$$
\begin{aligned}
& \text { \# Coquette . . . } \\
& \text { \# } \quad \text { Grandiflorus... } \\
& \text { \# }
\end{aligned}
$$

Potentilla Fruticosa

Prunus Japonica, flore plena. White and pin i. Pissardi

Pyrus Japonica.

Rhus Cotinus

"Typhina Laciniata

Rhodotypus Kerrioides

Ribes Aureum

Salisburia Adiantifolia

Sambucus Nigra Aurea

Spiraea Anthony Waterer

Arguta Multiflora

“ Billardi Alba

“ Callosa Rosea.

- Lindleyana

. Margaritz

“ Opulifolia Aurea

Prunifolia

“Reevesii, fl. pl.

4 Thunbergii

Symphoricarpus Alba

syringa. Charles X. Heavy plants

$$
\text { ¿ C. B. Van Ness }
$$

is President Grevy

Souvenir de Louis Spaeth

Tamarix Africana

“ Hispida Estivalis Indica

Viburnum Lantana

$$
\text { ". Opulus : }
$$

Vitex Agnus Castus

Weigelia Amabilis

$$
\text { “ Candida . }
$$

Incheshigh Doz. Per 100 pot grown \$200 \$1500 $\begin{array}{llll}30 & 175 & 1200 \\ 36 & 175 & 1200\end{array}$

$\begin{array}{llll}36 & 1 & 75 & 1200 \\ 36 & 1 & 75 & 1200\end{array}$

$\begin{array}{lll}36 & 175 & 1200\end{array}$

$\begin{array}{lll}30 & 175 & 1200\end{array}$

$\begin{array}{llll}30 & 1 & 75 & 1200\end{array}$

$\begin{array}{llll}36 & 1 & 75 & 1200\end{array}$

$\begin{array}{rll}24 & 175 & 1200\end{array}$

$\begin{array}{rll}24 & 175 & 1200\end{array}$

$\begin{array}{lll}36 & 175 \quad 1200\end{array}$

$\begin{array}{lll}36 & 175 & 1200 \\ 30 & 200 & 1500\end{array}$

$\begin{array}{lll}4 \text { feet } & 350 \quad 2500\end{array}$

$\begin{array}{lll}36 & 175 & 1200\end{array}$

18 to $24 \quad 175 \quad 1200$

$\begin{array}{lll}24 & 175 & 1200\end{array}$

pot grown $200 \quad 1500$

$\begin{array}{llll}30 & 1 & 75 & 1200\end{array}$

$36 \quad 150 \quad 1000$

$\begin{array}{llll}18 & 1 & 75 & 1200\end{array}$

$\begin{array}{llll}36 & 175 & 1200\end{array}$

$36 \quad 150 \quad 1000$

$24 \quad 175 \quad 1200$

$\begin{array}{llll}24 & 175 & 1200 \\ 36 & 150 & 1000\end{array}$

$\begin{array}{llll}24 & 300 & 2000\end{array}$

30 to $36 \quad 300 \quad 2000$

30 to $36 \quad 300-2000$

2-year-old $175 \quad 1200$

$\begin{array}{llll}48 & 1 & 75 & 1200\end{array}$

$\begin{array}{llll}48 & 1 & 75 & 1200\end{array}$

15 to $18 \quad 100 \quad 800$

18 to $24 \quad 100 \quad 800$

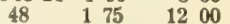

$\begin{array}{llll}48 & 175 & 1200 \\ 48 & 175 & 1200\end{array}$

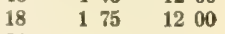

$\begin{array}{lllll}36 & 1 & 75 & 12 & 00\end{array}$

$\begin{array}{llll}24 & 175 & 1200\end{array}$

$48 \quad 175 \quad 1200$

$\begin{array}{lll}48 & 175 & 1200\end{array}$

$\begin{array}{llll}24 & 175 & 1200\end{array}$

$\begin{array}{lll}175 & 1200\end{array}$

$\begin{array}{llll}30 & 1 & 75 & 1200 \\ 36 & 1 & 75 & 1200\end{array}$

$\begin{array}{llll}36 & 1 & 75 & 1200 \\ 24 & 1 & 75 & 1200\end{array}$

$\begin{array}{rrr}30 & 175 & 1200 \\ 36 & 100 & 800\end{array}$

$\begin{array}{crrr}36 & 1 & 00 & 800 \\ 18 \text { to } 24 & 1 & 75 & 1200\end{array}$

24 to $30 \quad 175 \quad 1200$

$\begin{array}{lll}24 & 150 & 1000\end{array}$

$\begin{array}{llll}24 & 1 & 50 & 1000 \\ 48 & 1 & 75 & 1200\end{array}$

$48 \quad 175 \quad 1200$

$24 \quad 125 \quad 800$

$36 \quad 250$

$36 \quad 250$

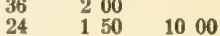

$24 \quad 175 \quad 1200$

$\begin{array}{lll}48 & 350 & 2500\end{array}$

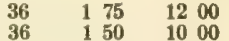

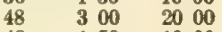

$\begin{array}{llll}48 & 150 & 1000\end{array}$

\begin{tabular}{llll}
48 & 1 & 50 & 1000 \\
\hline & 1 & 700
\end{tabular}

$\begin{array}{llll}24 & 1 & 75 & 1200\end{array}$

$\begin{array}{llll}48 & 1 & 75 & 1200\end{array}$

$\begin{array}{llll}48 & 175 & 1200\end{array}$

$\begin{array}{rrrrr}15 \text { to } & 18 & 1 & 00 & 800 \\ 36 & 1 & 75 & 1200\end{array}$

$\begin{array}{llll}36 & 1 & 75 & 1200 \\ 24 & 150 & 1000\end{array}$

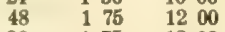

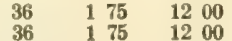

$30 \quad 150 \quad 1000$

$\begin{array}{llll}30 & 150 & 1000\end{array}$

$\begin{array}{lll}36 & 150 & 1000\end{array}$

24 to $30 \quad 400 \quad 3000$

24 to $30 \quad 400 \quad 3000$

24 to $30 \quad 00 \quad 3000$

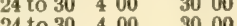

$\begin{array}{lll}24 & 300 & 400\end{array}$

$\begin{array}{lll}40 & 400 & 3000\end{array}$

$\begin{array}{lll}48 & 175 & 1200 \\ 48 & 200 & 1500\end{array}$

$\begin{array}{lll}48 & 200 & 1500 \\ 48 & 175 & 1200\end{array}$

$42 \quad 200 \quad 1500$

$42 \quad 175 \quad 1200$

$42 \quad \begin{array}{lll}42 & 72 & 00\end{array}$

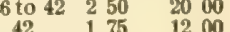

$\begin{array}{llll}42 & 175 & 1200 \\ 48 & 175 & 1200\end{array}$

$\begin{array}{lll}48 & 176 & 1200 \\ 48 & 175 & 1200\end{array}$

$\begin{array}{lll}48 & 1700 & 1200\end{array}$

$42 \quad 175 \quad 1200$ 


\section{Select Hardy Vines and Climbers}

\section{Akebia Quinata.}

We offer extra heavy pot-grown plants of this handsome climber. Strong, 5-inch pots, \$1.50 per doz; $\$ 10.00$ per 100 .

\section{Ampelopsis Veitchii.}

Strong, 2-year old, field-grown, $\$ 1.50$ per doz,; $\$ 10.00$ per 100 Extra selected plants, $\$ 2.00$ per doz.; $\$ 15.00$ per 100 .

\section{Ampelopsis Virginica (Virginia Creeper).}

Strong 2-year-old plants, $\$ 1.50$ per doz.; $\$ 10.00$ per 100 .

Ampelopsis Tricolor (Vitis Heterophylla Variegata).

Very strong, 4-inch pots, \$1.50 per doz.; $\$ 10,00$ per 100 .

\section{Ampelopsis Engelmanni.}

Extra strong, 2-year-old plants of this most useful variety. $\$ 1.50$ per doz.; $\$ 12.00$ per 100

\section{Ampelopsis Lowii.}

A new variety of the same general character as A. Veitchii and clinging to the smoothest surface without support, but with foliage much smaller and deeply cut. In spring and summer the leaves are of a bright apple-green color, changing to a brilliant crimson and scarlet in the autumn. 3-inch pots, 20 cts, each: 82.00 per doz.

\section{Apios Tuberosa.}

Strong tubers, $\$ 2.00$ per 100

Aristolochia Sipho (Dutcbman's Pipe Vine).

Extra heavy, $\$ 4.00$ per doz.; $\$ 30.00$ per 100

\section{Bignonia (Trumpet Creeper)}

Grandiflora. Strong plants, $\$ 3.50$ per doz.; $\$ 25.00$ per 100 Radicans. Strong plants, $\$ 1.50$ per doz.: $\$ 10.00$ per 100

Celastrus Scandens (Bitter Sweet, or Wax Work).

Strong plants, $\$ 2.00$ per doz.; $\$ 15.00$ per 100

\section{Cinnamon Vine.}

Strong roots, $40 \mathrm{cts}$. per doz.; $\$ 3.00$ per 100.

\section{Clematis Paniculata (Japanese Virgins Bower).}

We have an immense stock of exceptionally fine plants of this most popular of all the Clematis, and offer

Strong 3-year-old plants, $\$ 1.25$ per doz.; $\$ 8.00$ per $100 ; \$ 75.00$ per 1000 . Strong 2-year-old plants, 85 ets, per doz.; $\$ 6.00$ per $100 ; \$ 50.00$ per 1000 .

\section{Clematis Montana Grandiflora.}

Its flowers, which resemble the Anemone or Windflower, are snow white, $1 \frac{1}{2}$ to 2 inches in diameter, and frequently begin to expand as early as the last week in April, continuing well through May. Extra strong, 2-year-old plants. $35 \mathrm{cts}$, each; $\mathbf{8 . 5 0}$ per doz.

\section{Clematis Montana Rubens.}

Similar to the above in general habit but requires careful protection in winter, in color a pleasing shade of soft rosy-pink, and is perpetual flowering. $50 \mathrm{cts}$. each; 5.00 per doz.

\section{Large-Flowering Hardy Clematis.}

We have again this season a fine stock of good, strong plants, two years old, own roots.

Boskoop Seedling or Sieboldi. Extra large lavender

Duchess of Edinburgh. Double pure white.

Henryl. Finest large single white

Jackmani. The popular dark rich royal purple.

Madam Baron Velllard. Light rose, shaded lilac.

Vulle de Lyon. Bright carmine red.

$30 \mathrm{cts}$. each; $\$ 3.00$ per doz.; $\$ 20.00$ per 100 .

\section{Various Clematis.}

Per dox. Per 100

Coccinea. Two-year-old roots

Crispa. Two-year-old roots

Virginiana. Two-year-old roots

Integrifolia Durandi. of semi-climbing habit 125800 flowers. 35 cts, each.

\section{Euonymus Radicans.}

Strong, two year field grown plants of this desirable green cover plant. 1.25 per doz.; $\$ 8.00$ per 100 .
Euonymus Radicans Variegata.

A nice lot of 3 -inch pots. $\$ 1.00$ per doz.; $\$ 7.00$ per 100 .

\section{Hop Vines.}

Common Green Leaved. Roots $50 \mathrm{cts}$. per doz.; $\$ 4.00$ per 100 . Golden Leaved. $10 \mathrm{cts}$. each; $\$ 1.00$ per doz.

\section{Honeysuckles.}

Halleana. (Hall's Monthly) 21/2-inch pots .

Perdoz. Per 100

(Hall's Monthly) $2 \frac{1}{2}$-inch pots $\ldots . .8000$

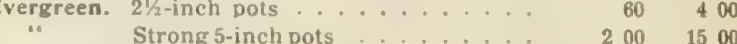

Varlegated. 21/2-inch pots........ 60400

Strong 5-inch pots ...... $200 \quad 1500$

Heckrothi. Strong, 2-year old, field grown . $\quad 200 \quad 1500$

Red Coral. Two year field grown ..... $200 \quad 1500$

\section{Hardy English Ivies}

An extra fine lot of strong, bushy plants in 4 -inch pots, $2 \frac{1}{2}$ feet high. $\$ 2.00$ per doz.; $\$ 15.00$ per 100, $2 \%$-inch pots, 50 cents per dozen; 83.00 per $100 ; \$ 25.00$ per 1000 .

\section{Hardy Jasmine.}

Nudiflorum. Yellow, 5-inch, pot-grown Officinale. White, 5-inch, pot-grown $\because \cdots:-150 \$ 1000$ Primulinum. An introduction from China, its flowers fully double in size to $J$. nudiflorum; these appear simultaneously with the leaves. Strong plants. $25 \mathrm{cts}$, each: $\$ 2.50$ per doz.

Lathyrus Latifolius (Everlasting Pea).

Albus. White

Per doz. Per 100

$8125 \quad 8800$

White Pearl." A magnificent, new, pure white variety, with in-

dividual flowers fully double the size of the ordinary Everlasting

Pea. We offer very strong roots at $25 \mathrm{cts}$. each; $\$ 2.50$ per doz.

\author{
Lycium Barbatum. \\ Chinese Matrimony Vine) \\ Strong 3-year-old plants, $\$ 1.50$ per doz; $\$ 10.00$ per 100
}

\section{Polygonum.}

Multiflorum. A very desirable climbing plant, of strong, rapid, but not coarse, growth. During September and October it produces masses of foamy-white flowers in large trusses. 1.50 per doz.: 10.00 per 100 .

Aubertl. Another strong-growing species which after it becomes thoroughly established produces masses of feathery white flower during the late summer and fall months. plants. 50 cents each.

Pueraria Thunbergiana (Kudzu Vine).

We offer a large stock of strong, 2-year-old plants of this rapid growing climber. $\$ 1.25$ per doz.; $\$ 8.00$ per 100 .

\section{Schizophragma Hydrangeoides.}

(Climbing Hydrangea).

One of the most interesting of our hardy climbers. Its flowers, which are borne in large trusses, are similar to white Hydrangea, and when in flower, during July and August, make a handsome and when in flower, during July and August, make a

Wistaria.

Extra heavy 2-year-old plants, well rooted.

Sinensis. Blue Multijuga. Blue

$\begin{array}{rr}\text { Per doz. Per } 100 \\ \text { I4 } 00 & \$ 3000 \\ 400 & 3000 \\ 400 & 3000\end{array}$

\section{Vitis Henryana.}

A new climber from China, foliage similar in outline but not as large as the Virginia creeper, foliage of great substance and prettily variecated the eround-color being deep velvety-green while the midrib and veins are of a silvery white. $30 \mathrm{cts}$ each $\$ 3.00 \mathrm{per}$ doz.

\section{Vitis Humulifolia.}

A rapid growing hardy climber with dark green hop-vine like leaves which are absolutely insect and disease proof. Always presenting a clean, fresh appearance, in late summer and fall the plant is loaded with pea-like berries, which are very attractive in the is loaded with pea-like berries, which are very attractive in the and purple, finally turning blue-black. $\$ 1.50$ per doz.; $\$ 10.00$ per 100 . 


\section{Dreer's Reliable Vegetable Seeds}

DREER'S VEGETABLE SEEDS have been for Seventy=five Years a Standard Among the Best Gardeners of this Country for Undoubted Purity and Excellence.

Artichoke. Large Green Globe. Oz., $30 \mathrm{cts}$; $3 / 4 \mathrm{lb} ., 85 \mathrm{cts}$.

ASPARAGUS.

Argenteuil, 5 lbs., $\$ 3.75$

Dreer's Ecilpse, the best, 5 lbs., $\$ 2.50$

Columbian Mam. White, 5 lbs., $\$ 2.25$

Conover's Colossal, 5 Ibs., $\$ 1.75$

BEANS. Dwarf or Bush. By Express or Freight. If bu mail add 15 cents per quart.

GREEN PODDED VARIETIES.

Imp. Red Valentine.

Burpee's Stringless Green Pod

Mam. Stringless Green Pod.

Black Valentine

Eariy Mohawk.

\begin{tabular}{|c|c|c|c|}
\hline $\begin{array}{l}\text { Qt. } \\
25 \\
30 \\
30 \\
30 \\
20\end{array}$ & $\begin{array}{r}4 \text { qts. } \\
8080 \\
100 \\
100 \\
90 \\
70\end{array}$ & $\begin{array}{rl}\text { Pk. } \\
\$ 1 & 25 \\
1 & 50 \\
1 & 50 \\
1 & 35 \\
1 & 25\end{array}$ & 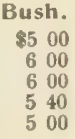 \\
\hline $\begin{array}{l}30 \\
30\end{array}$ & $\begin{array}{ll}1 & 00 \\
1 & 00 \\
1 & 00 \\
1 & 00 \\
1 & 15\end{array}$ & $\begin{array}{ll}1 & 50 \\
1 & 50 \\
1 & 50 \\
1 & 50 \\
1 & 65\end{array}$ & $\begin{array}{ll}6 & 00 \\
6 & 00 \\
6 & 00 \\
6 & 00 \\
6 & 60\end{array}$ \\
\hline $\begin{array}{l}40 \\
25\end{array}$ & $\begin{array}{ll}1 & 00 \\
1 & 00 \\
1 & 00 \\
1 & 40 \\
& 90\end{array}$ & $\begin{array}{ll}1 & 90 \\
1 & 90 \\
1 & 75 \\
2 & 25 \\
1 & 70\end{array}$ & $\begin{array}{ll}7 & 60 \\
7 & 60 \\
7 & 00 \\
9 & 00 \\
6 & 80\end{array}$ \\
\hline
\end{tabular}

Pencil Pod Black Wax . - - S - - Trawell

mproved Prollfic Black Wax

Golden Wax improved

BUSH LIMAS.

Dreer's Wonder

Dreer's Bush Lima.

Burpee's Bush Lima

Burpee-Improved

Henderson's Bush Lima

POLE OR RUNNING BEANS.

Early Leviathan Lima.

Slebert's Early Lima

Early Jersey Lima

Dreer's Improved Lima

Ford's Mammoth Lima

King of the Garden Lima

Dreer's Gol. Cluster Wax

Kentucky Wonder (Green-pod

BEETS, TABLE SORTS.

Crimson Globe

Dark-leaved Globe

Early Model

Early Eclipse

Extra Eariy Egyptian

Crosby's Egyptian

Edmand's Early Blood Turnip

Early Blood Turnip

Lentz Blood Turnip

Half Long Blood

Long Dark Blood

Giant Lucullus Swiss Chard

BRUSSELS SPROUTS.

Dreer's Matchless

Long Island Half Dwarf

CABBAGE.

Eureka, or First Early

Small Extra Early Jersey Wakefield

Selected Early Jersey Wakefield

The Charleston, or Large Wakefield

Dreer's Early Drumhead

mproved Early Summe

Succession

All Head

All Seasons (Vandergaw)

Lupton

Large Late Drumhead

Dreer's Selected Flat Dutch

Danish Roundhead

Danish Ball Head (Hollander)

Perfection Drumhead Savoy

Mammoth Rock Red.

CAULIFLOWER

Dreer's Earliest Snowstorm

Dreer's Selected Dwarf Erfurt

Dry-Weather

Early Snowball

Early Dwarf Erfurt

CARROT.

Dreer's Perfect Forcing

Earliest Short Horn

Early Scarlet Horn

Danver's Half Lon

Improved Rubicon Half Long

Sutton's Red Intermediate

Nichol's Imp. Long Orange

CELERIAC (Turnip Rooted Celery).

Apple Shaped

Giant Smooth Prague, the best

1/3-Ib. Lb.

80

50

40

Oz, $3 / 4$ =1b.

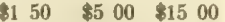

$\begin{array}{llll}75 & 250 & 800 \\ 75 & 250 & 800\end{array}$

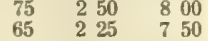

$50 \quad 150 \quad 500$

0z. 1/4-lb, Lb.

$25 \quad 85 \quad \$ 300$

$15 \quad 55 \quad 185$

$\begin{array}{llll}15 & 50 & 175 \\ 15 & 45 & 170\end{array}$

$15 \quad 50 \quad 175$

$\begin{array}{lll}20 & 60 & 225 \\ 15 & 45 & 150\end{array}$

15
20

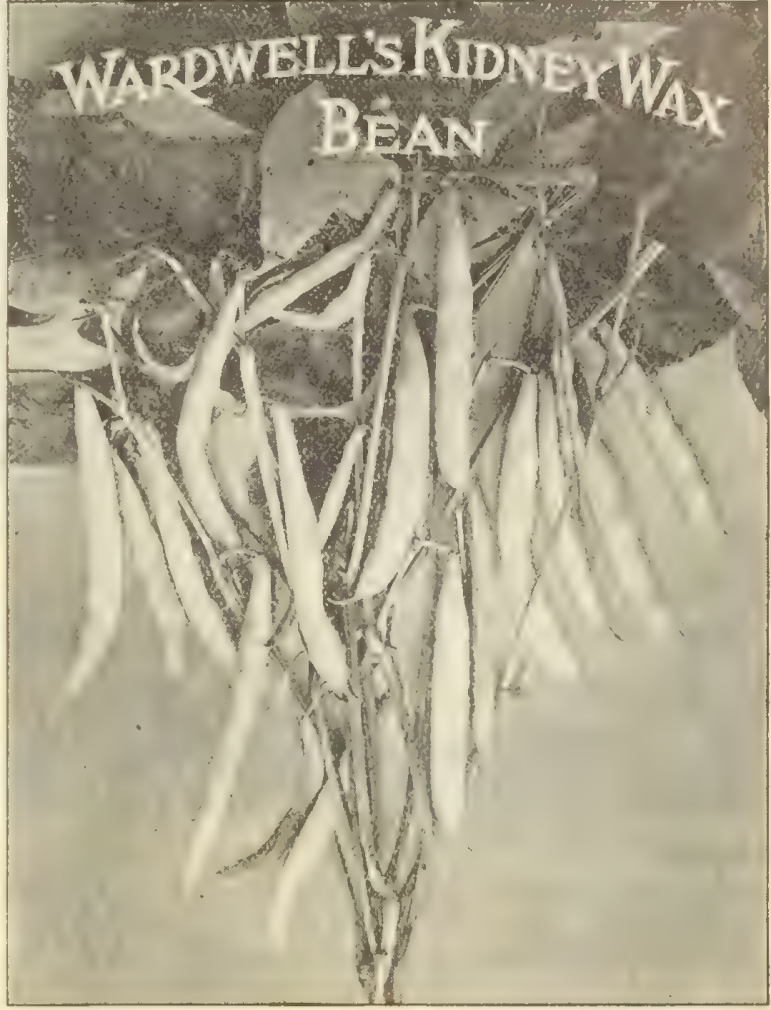

\section{CELERY}

Dreer's Monarch

Perfected White Plume

Golden Self-Blanching (American)

Columbia

The Shumacher

Winter Oueen

Giant Pascal

Perfection Heartwell

Golden Half Dwarf.

Boston Market

Golden Rose. Self-Blanching

CORN. Sweet Varieties. By Express or Freight. If by mail add to cents per quart.

Dreer's Aristocrat

Metropolitan

Early Evergreen

Early Champion.

Kendel's Early Giant

White Cob Cory

Early Minnesota

Crosby's Eariy

Stabler's Early

Country Gentleman

Stowell's Evergreen

Zir Zag Evergreen

Potter's Excelsior

Late Mammoth.

Qt. 4 Qts. Pk.

\section{CUCUMBERS.}

Davis Perfect

Arlington White Spine

Klondike

Imp. White Spine

Green Prolific

Chicago Pickling

Cool and Crisp

Nichol's Medium Green

Imp. Long Green

Everbearing

Cumberland

English Forcing, Telegraph, Duke of Edin =

burgh, Ston House Improved, each at $15 \mathrm{cts}$.

per pkt. of 10 seeds or 100 seeds for $\$ 1.40$.

CORN SALAD. Large Seeded. 5 lbs.. \$2.50 10
Bus.

$\$ 500$

460

420

460

420

420

480

500

400

460

420

Oz. 1/4-lb. Lb.

$10 \quad 30 \$ 100$

$\begin{array}{llll}15 & 35 & 125\end{array}$

100

100

80

80
80

80

80
80

80

100 


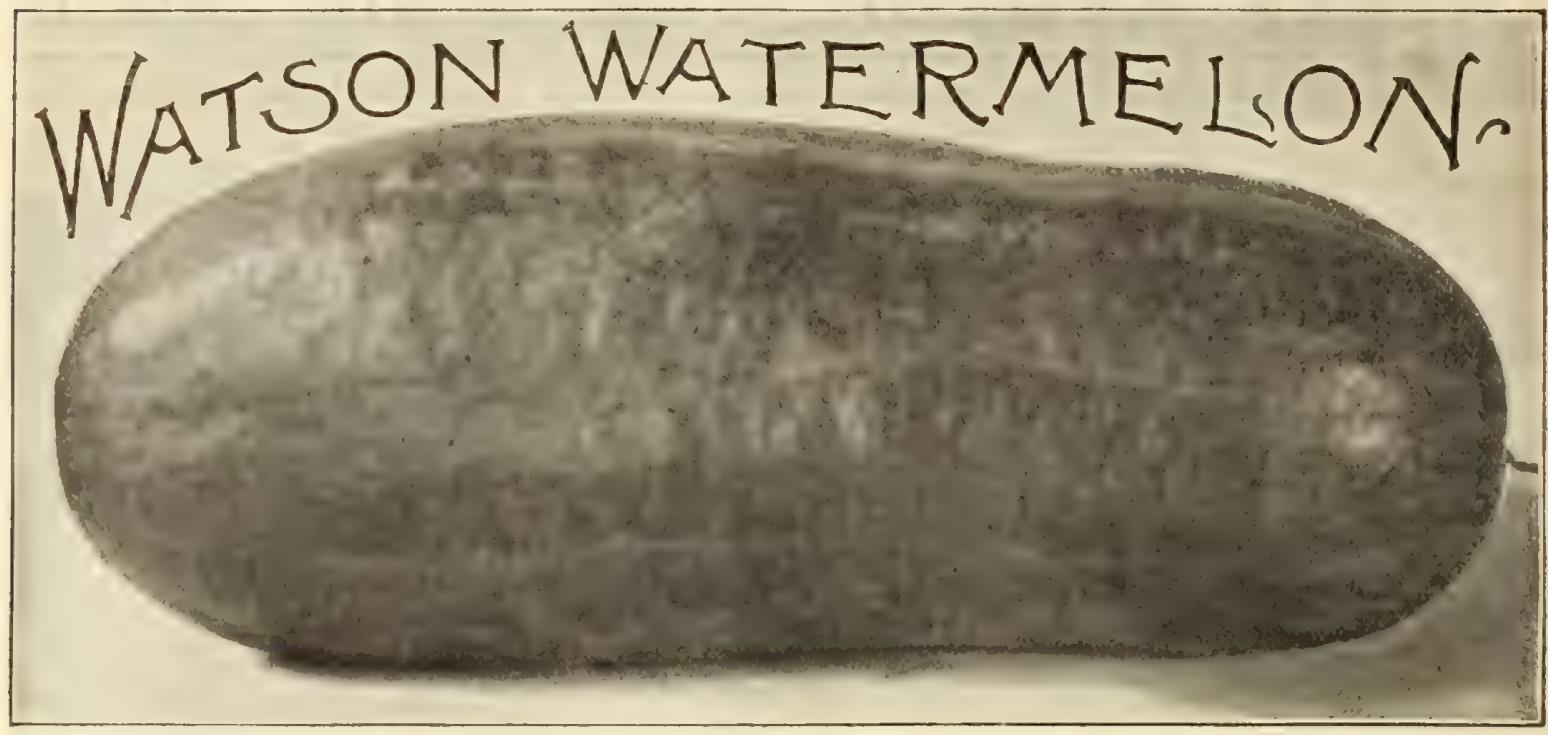

CRESS, or Pepper=Girass.

Extra Curled
Water Cress.

\section{EGG PLANT.}

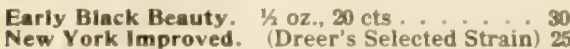
New York Improved. (Dreer's Selected Strain) 25

Black Pekin

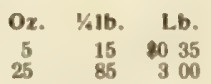

ENDIVE.

Dreer's Olant Fringed. Best variety

Green Curled

Broad-Leaved Batavian

$\begin{array}{rrr}100 & 3 & 75 \\ 90 & 3 & 25 \\ 60 & 2 & 25 \\ 90 & 3 & 25\end{array}$

KALE or BORECOLE.

Dreer's Imperial, Long standing, selected; 5 lbs.

Dwari Oreen Curled German

Dwarf Curled Scotch

Sea Kale

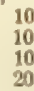

\section{KOHL-RABI.}

Ear. Frame Green Vienne

White or Green Vienn:

Early Purple Vienna.

\section{LETTUCE.}

May King. (Forcing.)

French Unrivalled

Big Boston. (Forcing)

Boston Market (Forcing)

Hittinger's Belmont. (Forcing

Grand Raplds. (Forcing

Golden Queen. (Forcing

All Heart, Dreer's

Wonderfu:

Early Dutch Butter, Spotted

Early Curled Simpson or Sllesia

Black Seeded Tennisball

Black Seeded Simpson

Sllver Ball

Improved Deacon

Dreer's Improved Hanson

Mammoth Salamander.

Salamander

Sensation

Kingsholm cos

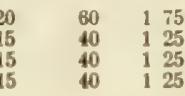

LEEK.

Dreer's Prizetaker

American Flag

Giant Carentan

\section{MUSHROOM SPAWN.}

Dreer's Reliable English Multrack Spawn.

Per brick, 15 cts.: (by mail, 25 cts): 1 doz. \$1.40; 25 lbs., \$1.60; 100 lbs., 8.00 ; $1000 \mathrm{lbs} ., 855.00$; 250 lbs. at 1000 lbs. rates.

Pure Culture Spawn. Per brick, 20 cts.; (by mail, 30 cts.) 6 bricks, $1.00 ; 12$ bricks, $11.75 ; 25$ bricks, $23.25 ; 50$ bricks, $\$ 6.00$.

French Mushroom Spawn. Loose in boxes. Per 3 lb. box, \$1.15.
MELON, MUSK.

Hoodoo

Admiral Togo

Defender

Paul Rose.

Burrell's Gem

Surprise.

Tip Top

Rocky Ford, Improved

Rocky Ford,

Jenny Lind

Netted Gem

Emerald Gem

Extra Early Hackensack

Miller Cream, or Osage

Montreal Market

MELON, WATER.

Watson. (See cut.).

Harris' Earliest

Blue Gem, or Iceberg

Monte Cristo, or Kleckley Sweets

Cole's Early

Cuban Queen

Florida Favorite

Kolb's Gem

Dixie

Alabama Sweet

Wonderful.

Mountain Sweet

Ice Cream

Colorado Preserving Citron

02. $1 / 4-1 b$. Lb.

\section{ONION}

Yellow Globe Danvers

5 lbs. br more at $\$ 1.50$ per lb.

Southport Large Yellow Globe

5 lbs. or more at $\$ 1.75$ per lb.
Phlla. Yellow Strasburg, or Dutch

5 lbs. or more at $\$ 1.00$ per $1 \mathrm{~b}$.

Prizetaker

Red Wethersfteld

Extra Early Red.

White Silver Skin, or Portugal

5 lbs. or more at 81.75 per lb.

Southport Large White Globe

$5 \mathrm{lbs}$. or more at $\$ 2.00$ per lb.

White Pearl

White Barletti

Mammoth Sllver King

\section{ONION SETS.}

Prices variable. Special prices on larger lots

Our sets are of the best quality only.

White Onion Sets

Yellow Onion Set

Red Onion Set.

Yellow Potato

White Muitiplier

Qt.
.20

15
20

.20

20

OKRA, or Gombo.

Perkin's Long Pod

Improved Long Green

0x. $1 / 4=1 b . \quad L b$

PARSNIP.

Improved Hollow Crown. 5 lbs., \$2.50 . . . $10 \quad 20 \quad 60$ Student or Guernsey. 5 lbs., \$2.50..... $10 \quad 20$ 
PARSLEY.

Dreer's Dwarf Perfection

Champion Moss Curled

Turnip-rooted, or Hamburg

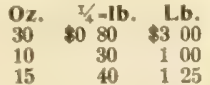

PEPPER.

Chinese Giant. $1 / 2-0 z$., $20 \mathrm{cts}$.

Hot Bell

Oiant Crimson

Large Bell or Bull Nose.

Large Sweet Spanish

Ruby King

Long Red Cayenne

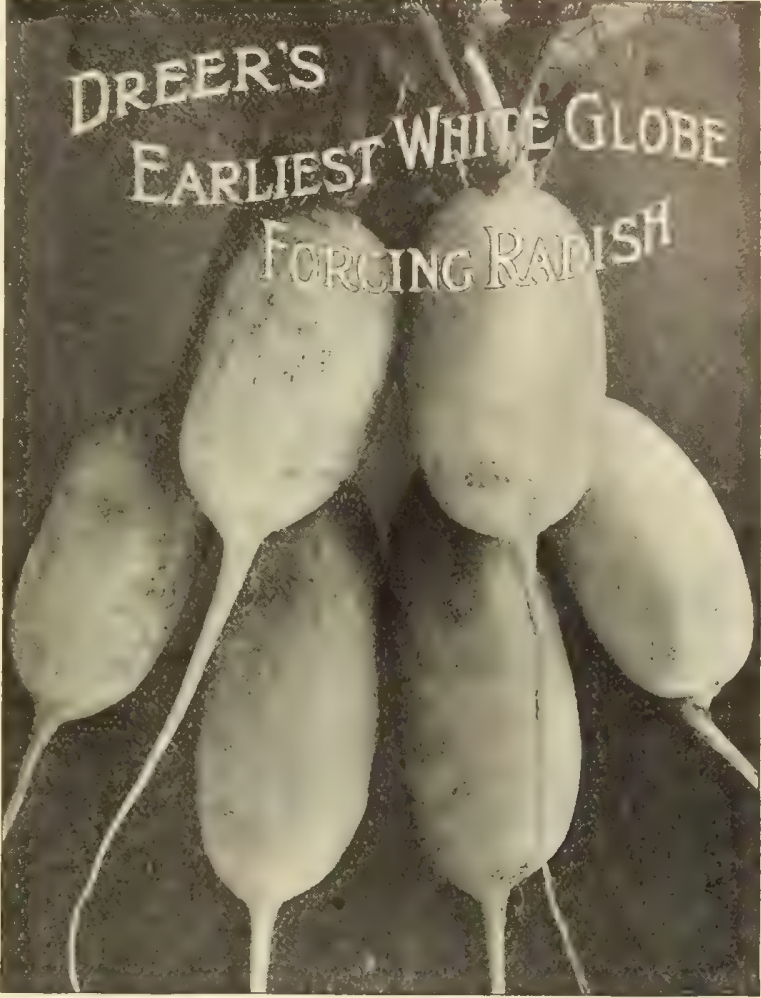

RADISH-Continued.

Dreer's First and Best

Long Scarlet Short ToD

Cincinnati Market

Felton's Sel. White Box. 5 lbs., $\$ 3.25$

Icicle

Beckert's Chartier

White Strasburg

Long White Vienna

Winter Varieties.

White Chinese, or Celestial

Long Black Spanish

Round Black Spanish

Krewson's Oblong Black Spanish

Scarlet China.

SALSIFY (Oyster Plant)

Mammoth Sandwich Island

Long White

$\begin{array}{llll}10 & 35 & 1 & 25 \\ 10 & 30 & 1 & 00\end{array}$

\section{SPINACH.}

Dreer's Savoy=Leaved

Victoria. Best Long-Standing

Long-Standing
Prickly-Seeded

Long Season.

b. 5 lbs. Bu, of

$20 \$ 080 \quad 500$

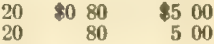

$20 \quad 80 \quad 500$

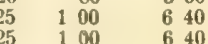

\section{SQUASH.}

Early Jersey White Bush

Early White Bush

Goiden Custard Bush

Yellow Summer Crookneck

Giant Crookneck.

Boston Marrow

Hubbard

Golden Hubbard

Warted Hubbard

Oz. $1 / 1-1 b . \quad$ Lb

$\begin{array}{llll}10 & 30 \quad \$ 1 & 00\end{array}$

$\begin{array}{lll}10 & 25 & 65 \\ 10 & 25 & 75\end{array}$

$10 \quad 25 \quad 85$

$\begin{array}{lll}10 & 25 & 75 \\ 10 & 25 & 75\end{array}$

$\begin{array}{lll}10 & 30 & 100\end{array}$

$\begin{array}{lll}10 & 25 & 85 \\ 10 & 25 & 85\end{array}$

$\begin{array}{lll}10 & 25 & 85 \\ 10 & 25 & 85\end{array}$

TOMATO

Lorillard. Forcing

Comet. Forcing

Frogmore

June Pink

Acme

Trophy

Favorite

Beauty

Dwarf Stone

Stone (Dreer's Selected Stock)

Matchless

Paragon

Dwarf Champion

Ponderosa

Golden Oueen $\begin{array}{rrr}\text { Oz. } & 1 / 4-\mathbf{l b} & \text { Lb. } \\ 10 & \$ 025 & 8080 \\ 10 & 20 & 60 \\ 10 & 25 & 80 \\ 10 & 20 & 60 \\ 10 & 25 & 80 \\ 10 & 25 & 80 \\ 10 & 25 & 80 \\ 10 & 25 & 80 \\ 10 & 25 & 80\end{array}$

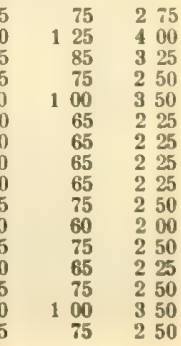




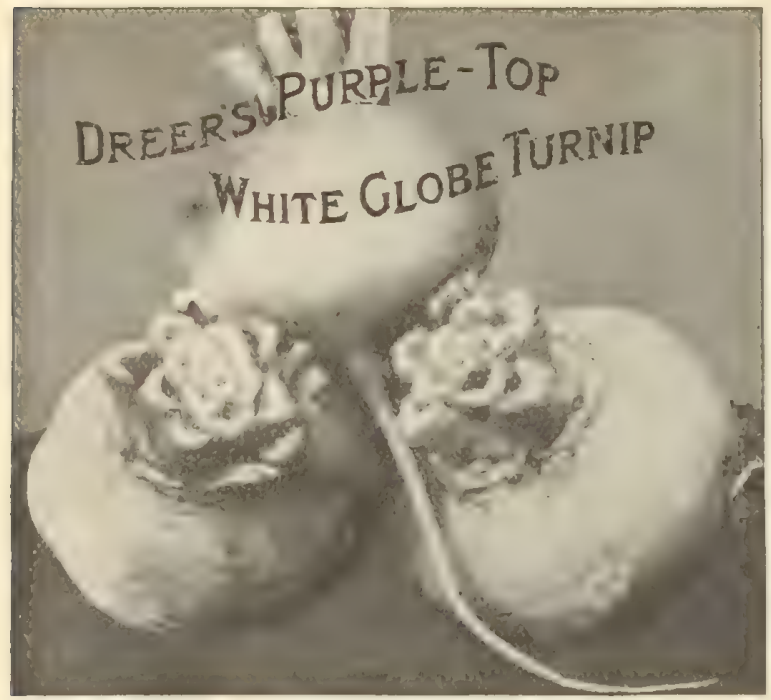

TURNIP.

Red, or Purple Top Strap Leaf

Purple Top, White Globe, (See cut)

Extra Eariy Mulan, purple too

Early Munich White Milan

Early White Flat Dutch

Early White Eg:

Snow Ball

Long White, or Cowhorn.

Long white, French

Yellow Globe, or Amber

Yellow Aberdeen

Golden Ball

Am. Purple Top Rutabaga

Dreer's Improved Purple Top Rutabaga

Budlong's White Rutabaga
HERB SEEDS.

Anise : Basil Sweet

Caraway

Dill

Sage

Savory, Winte

Savory, Summer

Sweet Marjoram (Imported

Thyme, Broad-leaved English

Thyme, French Summer...

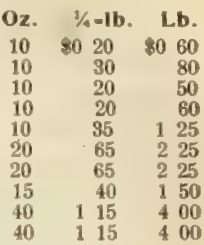

\section{Vegetable Plants and Roots.}

Asparagus Roots. Fine two-year old roots.

Argenteuil (Violet). Dreer's Eclipse, Palmetto, Barr's Mammoth and Conover's Colossal. 50 cts. per 100; 4.00 per 1000. Special prices on large quantities.

Dreer's Asparagus Circular free on application.

Artichoke Plants-Dreer's Selected Large Green. \$1.00 per doz.: \$.7.00 per 100.

Celery Plants. Ready July 1st.

Golden Self-Blanching White Plume, Dreer's Monarch, Giant

Pascal, Schumacher, Winter Queen. $30 \mathrm{cts}$. per 100; $\$ 2.50$ per 1000.

Chamomile. $85 \mathrm{cts}$. per doz.; $\$ 6.00$ per 100.

Chives. 75 cts. per doz: 85.00 per 100.

Hop Vine Roots. 60 cts. per doz.: $\$ 4.00$ per 100

Horse Radish Sets, Bohemian. 60 cts. per 100; $\$ 5.00$ per 1000

Lavender Plants. $10 \mathrm{cts}$. each; $\$ 1.00$ per doz; $\$$ i.00 per 100 .

Pennyroyal. $10 \mathrm{cts}$. each; $85 \mathrm{cts}$. per doz.; $\$ 6.00$ per 100.

Peppermint, $10 \mathrm{cts}$, each; 60 cts. per doz, 84.00 per 100.

Spearmint. $10 \mathrm{cts}$ each; $60 \mathrm{cts}$. per doz.; 4.00 per 100.

Rhubarb Roots. Myatt's Victoria. Strong Roots. 60 cts, per doz.: 84.00 per 100.

Rosemary. 10 cts. each; 85 cts. per doz.; $\$ 6.00$ per 100.

Sage, Holt's Mammoth. 85 cts. per doz.; $\$ 6.00$ per 100

Savory, Winter. $\$ 2.00$ per doz.; $\$ 15.00$ per 100 .

Tansy. $\$ 1.00$ per doz; ; $\$ 7.00$ per 100.

Tarragon. $15 \mathrm{cts}$. each; 81.50 per doz.; $\$ 10.00$ per 100 .

Thyme. Broad-leaved English. $75 \mathrm{cts}$. per doz.; 85.00 per 100

\section{ADD TO YOUR INCOME BY SELLING

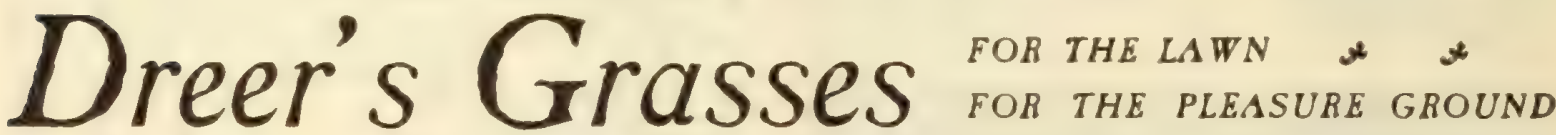

These are put up in attractioe packages and sell rapidly, thereby bringing the dealer an extra revenue at little erpense or trouble. Handsome colored posters for hanging in store to advertise our Grass Seeds furnished free.

Dreer's Fairmount Park Lawn Orass is put uo in illustrated auart and pint boxes, and sells rapidly. Price: One-pint boxes, $\$ 7.00$ per 100. One-quart boxes, 811.00 per 100

Seed of Dreer's Fairmount Park Lawn Grass in Bulk. Per bushel 20 lbs.) $\$ 2.75$.

The "Dreer" Lawn Grass. The best lawn mixture we sell and will prove satisfactory wherever used. It quickly produces rich, velvety and permanent lawns. Per bushel (20 lbs.), \$4.00.

Dreer's Seashore Lawn Grass. Excellent for use in sandy soils. Per bushel (20 lbs.), 4.00 .

Dreer's "Shady Place" Lawn Grass. Used for sowing in shaded portions of lawn, and is also a good mixture to sow in open situations. Per bushel (20 lbs.) $\$ 4,00$.

Dreer's Evergreen Lawn Grass Seed. This mixture produces fine lawns in a remarkably short time. We recommend this as a good mixture for general purposes. Per bushel (20 lbs.), 3.25 .

Dreer's Golf Links Mixture. Excellent for Golf Greens, Tennis Courts, Croquet Grounds, etc. Per bushel (15 lbs.), \$2.50.

Dreer's Putting Green Mixture. Made of fine-bladed grasses and excellent where fine-leaved grass is wanted. Per bushel (20 lbs.), 85.00 .

\section{CLOVER.}

PRICES SUBJECT TO CHANGE.

White Dutch.

Red or Medium. (Write for sample and price).

Alfalfa or Lucerne. (Write for sample and price)

Alsike. (Write for sample and price)

Scarlet or Crimson. (Write for sample and price.)

\section{CHOICE GRASS SEEDS.}

TERMS on Orass and Clover, NET CASH

PRICES SUBJECT TO CHANGE.

Kentucky Blue, Fancy ....... Bus. (14 lbs.) $\$ 225$ Bus. (14 lbs.) 175 Per bag of 50 lbs. 600 " " fancy cleaned... Bus. (32 lbs.) 600

Meadow Fescue . Bus. (22 lbs.) \& 25

Tall Meadow Fescue ........ Bus. (14 lbs.) 375

Sheep Fescue. . . . . Bus. (12 lbs.) 275

Red or Creeping Fescue ...... Bus. (14 lbs.) 350

Fine Leaved Sheep's Fescue .. Bus. (14 lbs.) 600

Hard Fescue Bus. (12 lbs.) 275

Wood Meadow Grass ........ Bus. (14 lbs.) 525

Orchard Grass. . Bus, (14 lbs.) 250

English Rye Grass... ....... Bus. (24 lbs.) 200

Italian Rye Grass . . . . . . Bus. (18 lbs.) 175

Rhode Island Bent........... Bus. (14 lbs.) 400

Bus. ( 7 lbs.) 200

Sweet Vernal Perennial

(Lb. 50 cts.)

Rough Stalked Meadow . . . . Bus. (14 lbs.) 600

Crested Dogstall .. . . . . . Bus. (21 lbs.) 675

Creeping Bent Grass. . . . . Bus. (20 lbs.) 600

Tall Meadow Oat.......... Bus. (10 lbs.) 200

Awnless Brome Orass Bus. (14 lbs.) 275

Timothy. (Write for sample and price)
1500

1000

1000

1800

1300

2500

200

2400

4000

2000

3500

1600

750

750

2700

2750

4000

3000

2800

1800

1800 


\section{Dreer's Flarist Specialties}

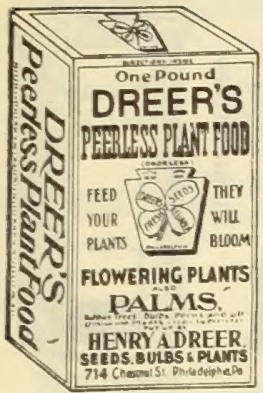

\section{DREER'S}

PEERLESS PLANT FOOD

This excellent fertilizer is put up in half pound and one pound packages; these are neat and attractive. Directions for use with each package. Florists can make a good profit. The "Peerless" is known throughout the country, and ean be found among the stock of the leading florists. Retail price, 15 and 25 cents. Price to florists, half pound packages, per doz. $\$ 1.00$; per $100, \$ 8.00$. For pound packages, per doz., $\$ 1.50$; per $100, \$ 12.00$. (Registered in Penna. only.)

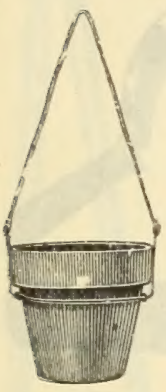

\section{DREER'S WIRE POT HANGER}

An ingenious arrangement of wire, easily applied, comes in good use in overcrowded greenhouses, used for hanging pots of ferns, orchids and other plants which are benefited by being put in open space. It also helps the general appearance of a greenhouse by placing nice specimens in full view.

\section{SIZE. \\ 5 -inch}

7-inch $\}$ doz., 25 cents ; gross, $\$ 2.50$.

8-inch

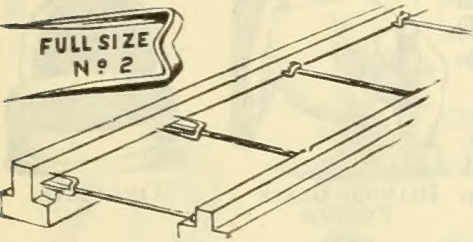

Dreer's Peerless Glazing Points

Galvanized

Pat'd March 26, 1901

Once used! Always used !

The Peerless Glazing Point is the only perfect Point known. The latest improvement is that both points are beveled on top and will hug close to glass when driven. Three sizes, No. 1, for small single thick glass; No. 2, for medium double thick glass ; No. $2 \frac{1}{2}$, for large double thick and skylight glass. Price per 1000, 60 cents ; post paid, 75 cents. $5000,82.75$ by express.

\section{DREER'S SPECIAL GREENHOUSE WHEELBARROW}

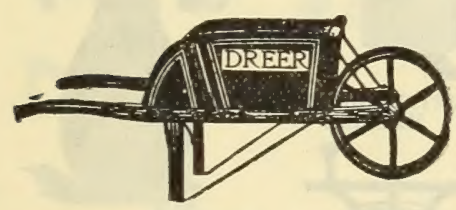

A strong, well-construc ted barrow, made specia for greenhouse work, being only $21 \mathrm{in.}$ wide at end of handles, so it may be used between staging. Medium size only. $\$ 4.25$

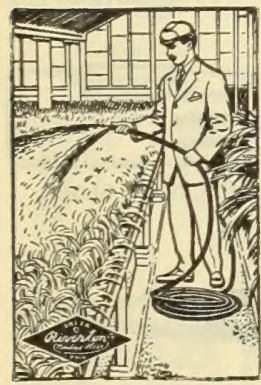

DREER'S New Brand-New Style Hose, "RIVERTON."

This hose can be furnished in continuous lengths up to 500 feet without seam or joint. Will withstand 50 per cent. more pressure than the old style hose. Couplings supplied with 25 feet lengths and over. The "RTVERTON" is guaranteed, and is the best hose for florists' use. Will not kink, will not harden or become brittle. It is utterly impossible for it to open or unwrap. See that it bears our name and brand, "RIVERTON." $3 / 4$-inch, per foot, 15 cents ; in reels of 500 feet, $14 \frac{1}{2}$ cents per foot; two reels, 1000 feet, 14 cents per foot. $1 / 2$-inch, 13 cents per foot; in reels of 500 feet, $12 \frac{1}{2}$ cents per foot; two reels, 1000 feet, 12 cents per foot.

\section{DREER'S TOBACCO SOAP}

The best insecticide for house and outdoor plants known, is carefully prepared and will be found to be just what we call it. Special care has been taken in preparing this soap, so as not to burn the foliage of plants either indoor or outside. It is not offensive, is easily dissolved and easily applied. Directions with each package. Retails at 25 cts. each. Per dozen packages, $\$ 2.00$; per 100 packages, $\$ 15.00$.

$10 \mathrm{lb}$. cans in bulk, $\$ 3.00$.

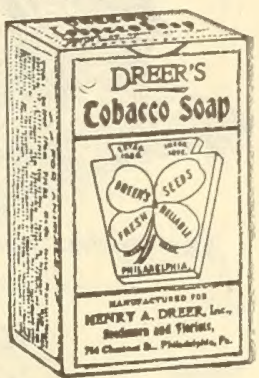

DREER'S SPECIAL BONE FLOUR

A superior carefully prepared fertilizer for florists' use. Special for rose growers, 100 lbs., $\$ 2.25$; bbl., 200 lbs., $\$ 4.00$; ton, $\$ 35.00$.

\section{DREER'S "RIVERTON SPECIAL" CEDAR TUB} Manufactured for Henry A. Dreer, Inc., exclusively
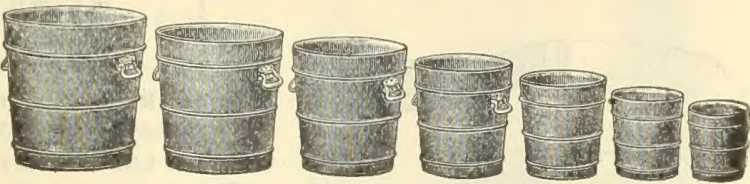

This entirely new tub is by far the neatest, cheapest, lightest and best Florist Tub ever offered. Made of cedar with electric welded hoops, painted green, with drop handles, presenting a very neat appearance. Just the tub for large specimen plants of any kind: will not break in shipping and always presents a neat appearance. The four largest sizes are supplied with drop handles.

$$
\text { Outside Inside Length of }
$$

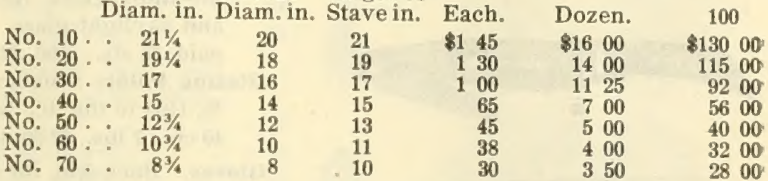

\section{ANDERSEN'S DAYLITE GLASS CLEANER}

This preparation will clean greenhouse glass of all foreign matter except paint. It is self-acting. The minute it is put on the glass it commences to do the work. Apply with a brush, leave it on a few minutes, then rinse off with cold water, use a garden hose if possible. Very little rubbing necessary. It will not injure paint or putty, will leave the glass clean and free from grease.

The cost of cleaning a greenhouse glass is about one-fifth of a cent per square foot. One gallon will clean from 400 to 600 square feet. 25 to 50 gallons, per gal., 70 cts.; 5 to 25 gallons, per gal., 80 cts. less than 5 gallons, $\$ 1.00$ per gal.

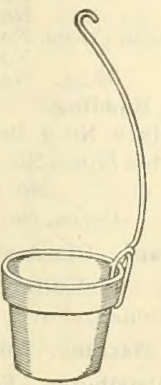

\section{EUREKA STEEL WIRE POT HANGER}

15 inches long, suitable for holding any size pot up to 8 inches, specimen plants can be suspended overhead into full sunlight, where they will develop sooner than in crowded bench. 50 cents per dozen; $\$ 3.00$ per 100 .

\section{DREER'S IRON PLANT STAND}

Very useful for elevating heavy plants in overcrowded greenhouse, also useful in decorations; very good, strong and neat.

Size

15-inch

18 "

24

$\underset{. \$ 050 \quad \$ 065}{\text { Black Galvanized }}$

30

60

75

90

75

36

110

90
$1 \quad 10$

125

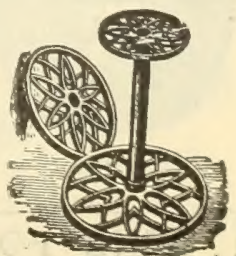

Discount, 10 per cent. from the above prices. 


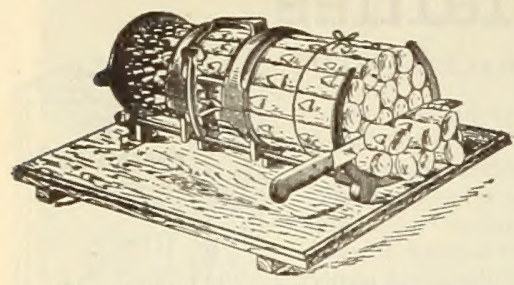

PHILADELPHIA ASPARAgus BUNCHER

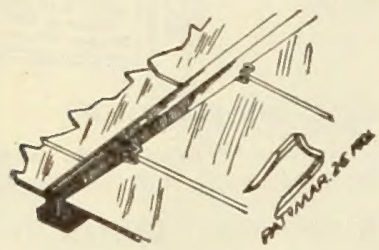

Peerless Glazing Points
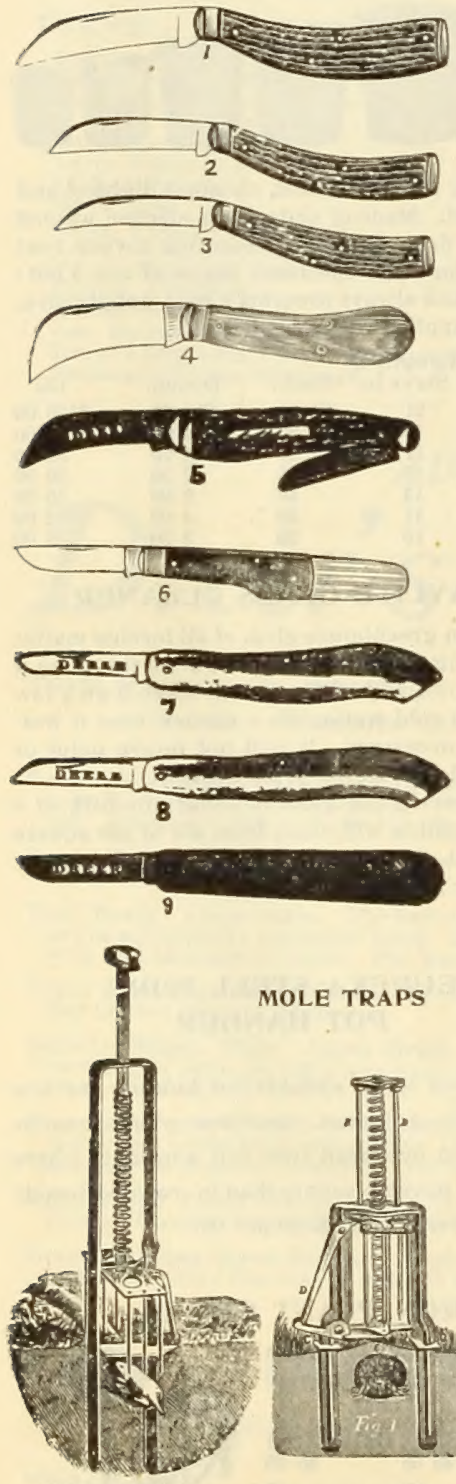

REDDICK

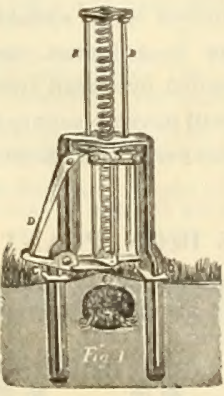

OLMSTEAD

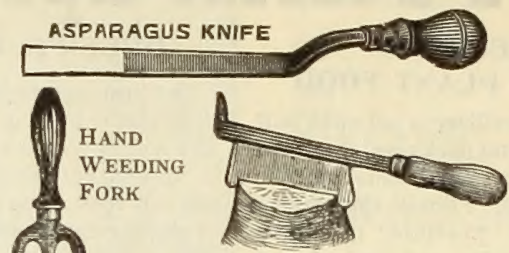

GRAFTING TOOL
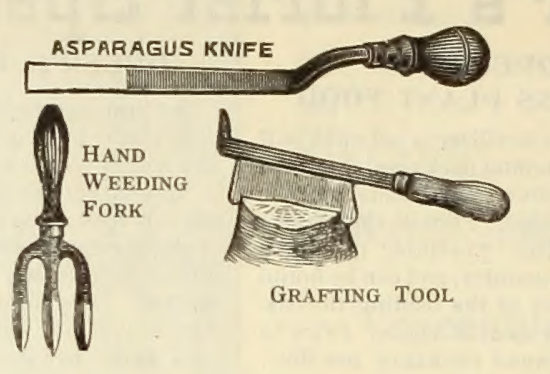

Asparagus Buncher, Philadelphia, complete . \$1 75 Acme, complete

Asparagus Knife, American, plain,

and weed cutter

Dibbles, iron, 35 cts.; iron pt., 40 cts.; brass pt., 50 cts. Forks, hand weeding, steel

Fumigators. Perfection and Eureka. The perfection has vapor tank; prevents scorching.

Size. For Greenhouse. Eureka. Perfection. $\begin{array}{rrrr}1 & 10 \times 20 \mathrm{ft} & \$ 100 & \$ 275 \\ 2 & 12 \times 40 \% & 150 & 325 \\ 3 & 15 \times 100 \cdots & 200 & 375 \\ 4 & 20 \times 100 * & 300 & 500\end{array}$

Garden Reels, iron, small, 50 cts.; large, 75 cts.; galvanized, large, \$1.25; heavy, double, $\$ 2.00$.

Garden Lines. Best Italian Flax.

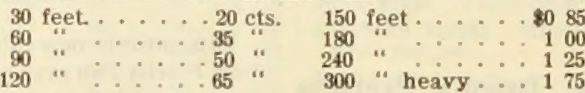

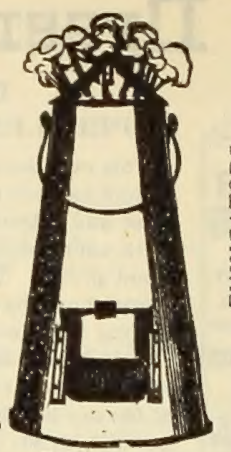

EUREKA

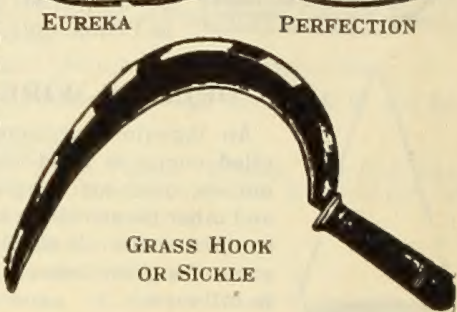

Stag, No. 5,2 blades.

$$
\text { Cocoa, No. 9, ...... } 50 \text { " }
$$
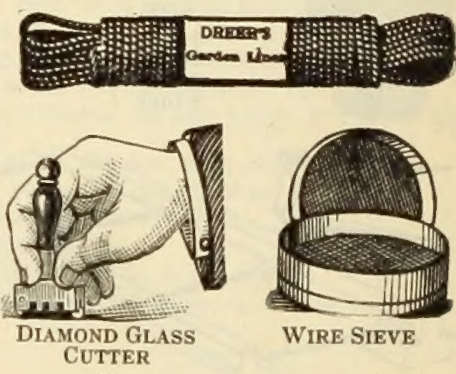
$\begin{array}{llll}120 & 300 " \text { heavy } \ldots & 175 \\ \text { Glass Cutter. Small diamond, } \$ 2.50 \text {; large, } \$ 8.75 ;\end{array}$ steel wheel, 15 cts.; doz., $\$ 1.50$.

Glazing Points, Peerless. Three sizes. No, 1, for small single thick glass; No. 2, for medium double thick glass; No. $2 \frac{1}{2}$, for large double thick and skylight glass. Price per 1000,60 ets; postpaid, 75 cts.; $5000,82.75$, by express.

Glazing Points. Siebert's Zinc Brads. Two sizes, $\%, 1400$ to the $1 \mathrm{~b}$.; $\%, 1150$ to the $1 \mathrm{~b}$. Price $1 \mathrm{lb}$. 40 cts.; 7 lbs., $\$ 2.50 ; 15$ lbs., $85 ; 1$ lb. by mail, 55 cts.

Gloves. Buckskin, for pruning thorny plants, $\$ 1.00$. Grass Hooks (Sickles). English riveted back.

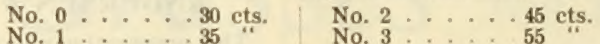
No.

Grass Hooks, American, plain, 25 cts.; English, solid steel, 30 cts.; Dreer's, 40 cts.; Dutch, 25 cts.; Little Giant, 40 cts.

Grafting Tools. Small, $50 \mathrm{cts}$; large, $75 \mathrm{cts}$.

Grafting Wax. 1/4-1b., 10 cts.; $1 / 2-1 b ., 15$ cts.; 1 lb., 25 ets.; 5 Ibs., $\$ 1.15 ; 10$ lbs., $\$ 2.00$.

Knives, Pruning.

American, medium to heavy, 50 cts.; 75 ets.; $\$ 100$ Imported, Stag, No. 1, very heavy,

No. 2, medium.

No. 3, light,

American Cocoa, No. 4, heavy,

Knives, Budding.

Imp. Horn, No. 6, Dreer's Special, 50 ets, and Imported Ivory, No. 7, 2 grades, . . . 75 cts. No. 8, 2 grades ... . 75

Mole Traps, Olmstead, 81.25; Reddick, $85 \mathrm{cts.}$

Mastica. A substitute for putty . . \$1.35 per gal. 5 gallons and over . . . .... 1.25

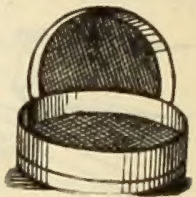

WIRE SIEVE

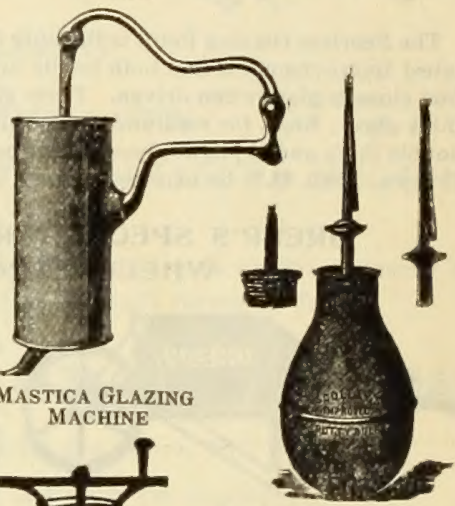

PutTy Distributer 35 1 90

Mastica Machine. For applying mastica, \$1.25. Putty Distributer. For putty or mastica, 85 cts. Twemlow's English Liquid Putty. 1 gal., \$1.45; 3 gals, $84.25 ; 5$ gals., $87.00 ; 10$ gal., $\$ 14.00$.

Raffia. For tying plants. Per lb., 14 cts.; 10 lbs., about 200 lbs., $\$ 10.00$ per 100 lbs.

Sieves. Best quality, 20 -in., light, 50 cts.; heavy, $60 \mathrm{c}$. $\$ 1.25$; 25 lbs., $\$ 3.00$; 100 lbs., $\$ 11.00$; original bale,

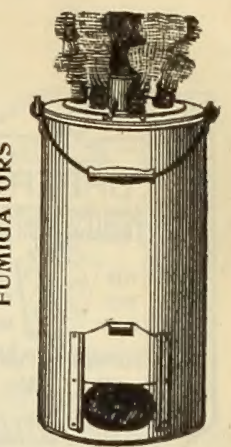




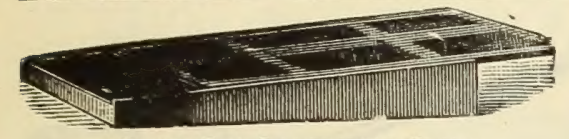

Plant Bed Protecting Cloth

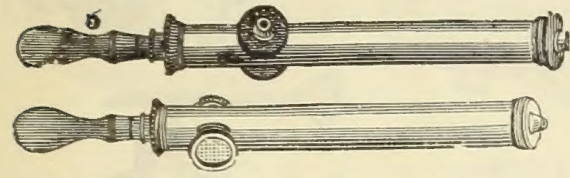

SYRINGES

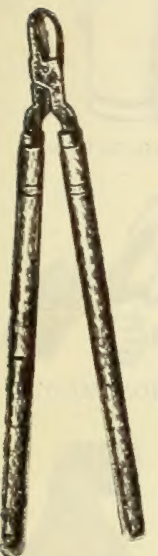

LOPPING SHEARS
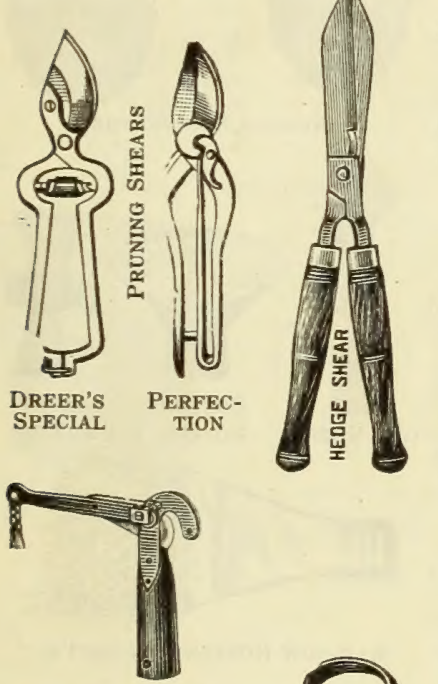
TELEGRAPH
TREE PRUNER

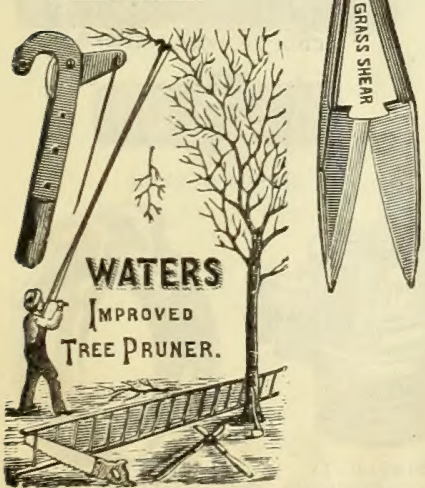
25-in. and . per doz.
Frem Scrapse.

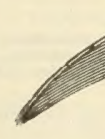

PLANT BED CLOTH,-For Shad ing or Protection from Frost. Light grade, 5 cts. per yd.; per piece of about 70 yds., 4 ets. per yd. Medium grade, 9 ets. per yd.; per piece of about $60 \mathrm{yds}$., 8 cts. per yd. Heavy grade, 12 cts. per yd.; per piece of about $40 \mathrm{yds}$., 11 cts. per yd. Samples mailed on application.

SHEARS. Hedge, English, 8-in., \$1.40; 9-in. $\$ 1.60 ; 10$-in., \$1.75; 12-in., \$2.25.

Pruning, Dreer's Special, 9-in., heavy, \$1.25.

French, 7 -in., $\$ 1.00 ; 8$-in., \$1.25; 9-in. $\$ 1.50$

Perfection, 7 -in.. \$1.50; 8-in., \$1.75; 9-in., $\$ 2.00$.

German, first quality, 8 -in., 75 cts.. 9-in., 90 cts. second quality, 8 -in., 40 cts.; 9 -in., 60 cts., small nickel, 75 cts.; large, 90 cts.

Grape, pruning, one size

Hand Shear Springs, elliptical, each

Lopping, Clipper, 20-in. handle, $\$ 1.00 ; 23$-in. $\$ 1.40$

Lopping, Imported, 27 -in., \$1.75; 31 -in., \$2.25; 38-in. $\$ 2.75$; 44 -in.

Tree-pruning, Waters', 4-ft., 65 cts; 6 -ft., 75 cts. 8 -ft., 90 cts.; 10 -ft,. $\$ 1.00 ; 12$-ft.

Tree-pruning, Telegraph, without pole. Blades for Waters' or Telegraph Shears

Sheep or Grass, English. $7 \frac{1}{2}-\mathrm{in} ., 85$ cts.; with spring, \$1.00. American, 25 cts.; 35 cts., 50 ets.

SAWS. Pruning, 14 -in., 50 cts.; 16 -in., 60 cts.; 18 in., 70 cts; 20 -in., 85 cts., 24-in. Double-edged, Lightning, 16-in. Adjustable Pole Tree Saw, 18-in. blade

SCYTHES. English Lawn, riveted back, best steel, 30 and 32 -in., $\$ 1.00 ; 34$-in., $\$ 1.10 ; 36$-in., \$1.15; 38-in.

Waldron, English Lawn, 36-in, to 40-in.

American Lawn, 75 cts.; Bush, short.

SCYTHE SNATH. Improved pattern

SCYTHE STONES. Darby, $10 \mathrm{cts}$; per doz., \$1.00; German, 10 cts.; per doz., 90 cts.; English, 15 cts. ;

SEED SOWER. Cahoon, Broadcast

STAKE FASTENER. The most convenient and economical tie for holding the lateral wire to steel stakes. Heavy. Price, $\$ 3.00$ per 1000 .

SYRINGES.

No. A. 1-stream and spray rose, $12 \times 1$ in. . 200

"C. 1 " " " "

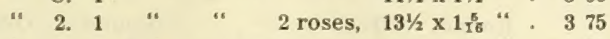

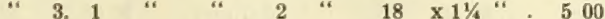

5. 1 " " 2 " $18 \times 1 \frac{1 / 2}{2}$. 600

H. $18 \mathrm{in.} \mathrm{long,} 1 \frac{1 / 2}{2}$ in. diameter ..... 225

ATOMIZERS. Tin, small, 30 cts.; large

Brass, small, 50 cts.; large

Brass, automatic, compressed air

THERMOMETERS. (Shipped at purchaser's risk. Japanned Tin Case, (tested), 8-in., 25 cts.; per doz. Japanned Tin Case (tested), 8-in., 50 ets.; 10-in. Hotbed or Dairy, all glass

Mushroom Bed, brass point, \$1.35; iron point

Self-Registering Tin Case . . . . . . . . Dreer's Special, wood base, oxidized scale . 50 and 75

TREE SCRAPERS. Steel, 10 and 20-in. handle . . . . . . . . 60

TROWELS. Steel, 6-in., 25 cts.; doz.

English Pattern, 6-in., 35 cts.; doz., \$4.00; 7-in.,

40 cts.; per doz.

Tomato, 50 cts. Transplanting

Steel Shank, fine quality, extra strong

SCYTHE

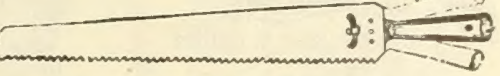

AdJUSTABLE POLE TREE SAW

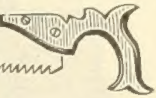

TREE SAW

8050

120

140
75

75

40

25

40

75

100

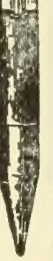

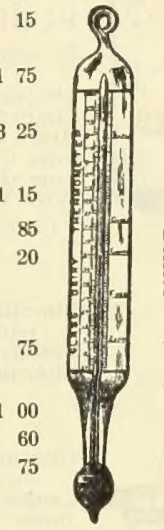

LIGHTNING TREE SAW

DREER'S RELIABLE THERMOMETERS
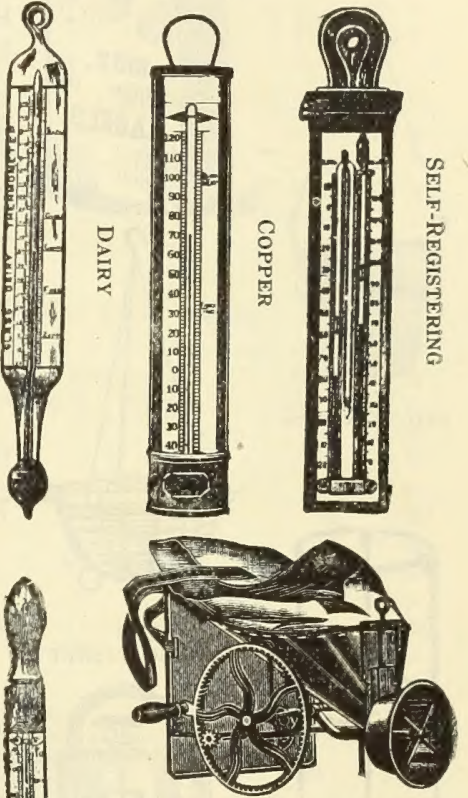

275 25

25 250 450
3 CAHOON SEFD SOWER

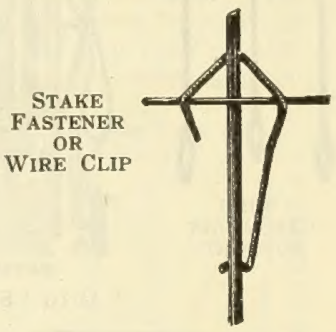

개개.

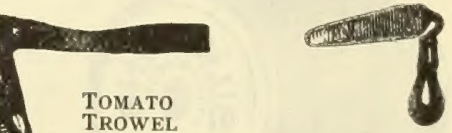

Transplanting Trowel

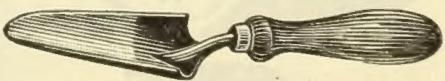

AMERicaN SteEL Trowel

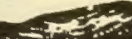




\section{DREER'S HIGH GRADE FERTILIZERS}

Cattle Manuro (Shredded). A pure manure, light, clean and easily handled. Used extensively for cut flower forcing. Price, F. O. B. Philadelphia: Sack of 100 lbs., \$1.50; 500 lbs., \$6.50; rooo lbs., \$12.50; ton (2000 lbs.), \$24.00.

Cattle Manure, F. O. B. Chicago: 100 lbs., $\$ 1.20 ; 500$ lbs., \$5.00; 1000 lbs., \$8.50; 2000 lbs., \$15.00.

Clay's Fertilizer. In original sacks, $1 / 4 \mathrm{cwt}$, \$r.75; $1 / 2$ cwt., $\$ 3.25$; I cwt. (II2 lbs.), \$6.00.

Dreer's Peerless Plant Food. $1 / 2-\mathrm{lb}$, boxes, ro cts.; $\$ 1.00$ per doz.; \$8.00 per 100; I-lb. box, 15 cts.; \$1.50 per doz.; \$12.00 per 100 ; retail at 15 and 25 cts. each. Registered in Pennsylvania only.

Pure Bone Meal. 100 lbs., \$2.00; 200-lb. sack, \$3.50; ton, $\$ 33.00$.

Pure Bone Flour. roo lbs., \$2.25; bbl., 200 lbs., $\$ 4.00$; ton, $\$ 35.00$.
Pure Ground Bone. 100 lbs., 2.00; 200-lb. sack, $\$ 3.50$; ton, $\$ 33.00$.

Fine Ground Bone. Contains 3\% ammonis, $16.49 \%$ phosphoric acid. 100 lbs., \$1.75; 200-1b. sack, \$3.25; ton, $\$ 30.00$.

Dried Blood Manure. The best known fertilixer for bastening crops in open air or under glass; a very rich food. roo lbs., \$3.50; 200 lbs., \$6.25.

Pulverized Sheep Manure ("Wizard Brand"), F.O.B Philadelphia: 100 lbs., \$1.50; 500 lbs., \$7.00; 1000 lbs. $\$ 13.50$; ton (2000 lbs.), \$25.00.

Pulverized Sheep Manure, F. O. B. Chicago: 100 lbs., \$1.25; 500 lbs., \$6.00; 1000 lbs., \$11.00; ton, \$18.00.

Nitrate of Soda. 50 lbs., \$2.00; 100 lbs., \$3.25; 200 lbs., \$6.00. Special price per ton on application.

Canada Unleached Hardwood Ashes. Used largely by the florists. Per bbl., \$2.50; per ton, $\$ 20.00$.

All Fertilizers f. o. b. Philadelphia. Special prices by carload.

\section{INSECTICIDES AND FUNGICIDES}

Aphine. For aphis, thrip, red spider and plant insects in general, being a strong nicotine extract. It dilutes I part to 40 parts of water. I qt., \$1.00; I gal., \$2.50.

Aphis Punk. A nicotine paper for fumigating. Box, 60 cts.; 12 boxes, $\$ 6.50$.

Arsenate of Lead. For all insects. The best codling moth, curculio and rose-bug remedy. Dilute $\mathbf{I} \mathbf{0 z}$. to $\mathbf{I}$ gal, of water. I lb., 25 cts.; 5 lbs., 90 cts.; 10 lbs., \$1.65; 25 lbs., \$3.75; 100 lbs., \$14.00. Special price on large quantities.

Bordeaux Mixture. (Liquid.) A mildew and fungus remedy. By adding water it is ready for use. I qt., 35 cts.; 1 gal., 90 cts. ; 5 gals., $\$ 3.75$. One gallon will make one barrel liquid.

Bordeaux Mixture Paste. For fungus, rust and all kinds of rot. Half strength for peach and plum trees. 5 ozs. to I gal. of water is standard strength. I lb., 20 cts.; 2 lbs., $30 \mathrm{cts}$; 5 lbs., $70 \mathrm{cts}$; 10 lbs., \$1.15; 25 lbs., \$2.35; 50 Ibs., \$4.25.

Bordeaux-Arsenate of Lead Mixture. A combined fungicide and insecticide. For apple and pear trees, potatoes, melons and cucumbers. 3 ozs. to I gal. of water. I lb., 20 cts.; 2 lbs., 34 cts.; 5 lbs., 80 cts.; 10 lbs. \$r.30; 25 lbs., \$2.75; 50 lbs., $\$ 5.00$

Bordeaux Mixture. (Dry.) Can be used dry or as spray. I-lb. box, $20 \mathrm{cts}$., makes 5 gallons spray. 5 lbs., $90 \mathrm{cts}$.

Copperine. Ammoniacal solution of carbonate of copper. Remedy against fungus, mildew, rust and black rot. Lb., 25 cts., makes 16 gallons of liquid; 5 lbs., \$1.00.; 10 lbs., \$1.75.

Copper Sulphate. For early spraying and making Bordeaux Mixture. Lb., 15 cts.; Io lbs., \$1.25.; 25 lbs., \$2.50.

Fir Tree Oll Soap. Used in washing down palms and plants infested with scale, aphis and mealy bug. $1 / 2 \mathrm{lb}$., $25 \mathrm{cts}$.; 2 lbs., 75 cts.

Grape Dust. For mould, mildew or rust mites, either in greenhouses or the open air. 5 -lb. pkg., $30 \mathrm{cts}$.

Hellebore. For currant worms and sucking insects. I lb., 20 cts.; 5 lbs., 75 cts.

Insect Powder. (Pure Dalmatian.) For roaches, ants, fleas, etc. I lb., $50 \mathrm{cts}$.

Kerosene Emulsion. (Liquid.) Concentrated. I qt., 35 cts.; I gal., 90 cts.; 5 gals., $\$ 3.75$.

Kerosene Emulsion. (Paste.) Ready for use by adding water. I-lb. can, I5 cts. ; 5-1b. can, 60 cts.; 25-lb. can, \$2.50; roo lbs., \$8.0o. One pound makes 10 gallons of spray.

Kill-0-Scale. A remedy against San Jose and other scale on trees and shrubs; I qt., 50 cts.; $1 / 2$ gal., 75 cts.; I gal., $\$ \mathbf{1} .25$, will dilute with 20 gallons of water; 5 and 10 gallon cans, \$1.00 per gal. Send for circular.

Lemon 0il. For all insects and scales. $1 / 2 \mathrm{pt}, 25 \mathrm{cts}$; pt., 40 cts.; qt., 75 cts.; 1/2 gal., \$1.25; gal., \$2.00. Dilute to 40 parts of water.

Nico Fume. Tobacco paper insecticide. This is the strongest tobacco paper on the market; does not injure blooms, and furnishes the easiest method for fumigation ever devised. Tin can of 24 sheets, 75 cts.; 144 sheets, $\$ 3.50 ; 288$ sheets, $\$ 6.50$.

Full directions for using with each package.
Nico-Fume Liquid. An effective vaporizing liquid. pt., 50 cts.; I pt., \$1.50; 1/2 gal., \$5.50; 1 gal., \$10.50.

Nicoticide. Fumigating compound. $4 \mathrm{oz}$, $70 \mathrm{cts}$; $/ / 2 \mathrm{pt}$., $\$ 1.25$; I pt., \$2.50; 1 qt., \$4.50; 1/2 gal., \$8.25; 1 gal., \$15.00. Vaporizing apparatus, $50 \mathrm{cts}$.

Nikoteen. An economical and powerful nicotine extract. One part to 600 of water to kill all insects, except scale, for which use I to 400 . Pint bottle, $\$ 1.50$; case of 10 bottles, $\$ 13.00$.

Potash Whale Oil Soap. (Good's.) Is recommended as a summer and winter wash for oyster shell and other scale insects. I lb., 15 cts.; 5 lbs., 70 cts.; 25 lbs., \$1.65.

Sulphur, Powdered. For mildew. Lb., 6 cts.; 5 lbs. 25 cts.; 10 lbs., 40 cts.; roo lbs., \$3.50.

Tobacco Dust. For fumigating or dusting, coarse or fine. I lb., 10 cts.; 5 lbs., 20 cts.; 50 lbs., \$1.50; 100 lbs., \$2.50.

Tobacco Soap. (Dreer's.) For all greenhouse plants, trees, cattle and all insect infested animals. Contains no injurious qualities. $1 / 2 \mathrm{lb}$., $20 \mathrm{cts}$; doz. \$2.00; per 100, \$15.00; Io lb. cans, (bulk), \$3.00. (Packages retail for 25 ceots.)

Tobacco Stems. For spreading under melons and cucumbers. Per bbl., \$1.00; per bale, \$1.50; ton, \$12.00.

Whale Oil Soap. An excellent tree wash. I lb., 15 cts.; 2 lbs., 30 cts.; 5 lbs., 50 cts.
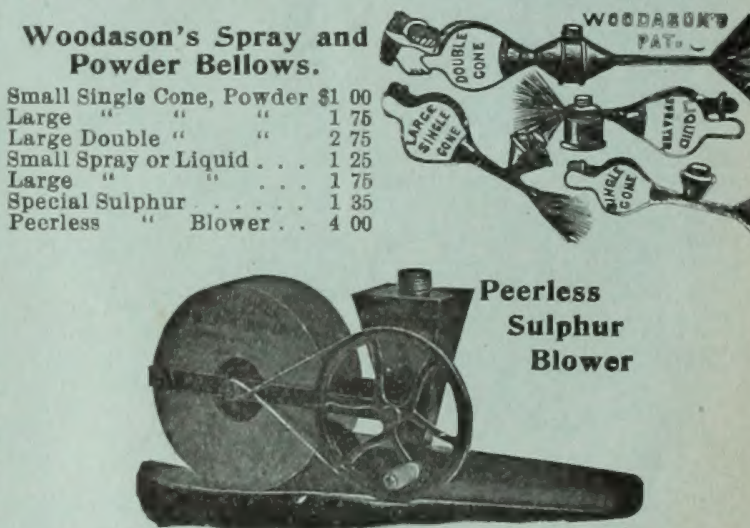

The Universal Soap Mixer.

No florist should be without one or two of these soap mixers. Simple in construction. Fill the mixer with small pieces of soap and attach to the faucet, connect up the hose and spray your plants with a fine nozzle under pressure, and keep your plants in a clean and healthy condition.

Complete. with directions, $\$ 5.00$.

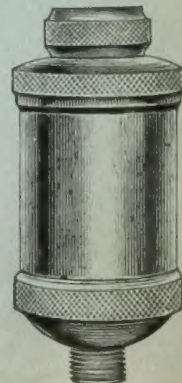

When wanted by mail, add 15 cents per $\mathbf{l b}$. 